\title{
GADAMER Y LOS PRESOCRÁTICOS. LA TEOLOGÍA DE LA ESPERANZA EN EL LÍMITE OCULTO DE LA HERMENÉUTICA
}

\author{
Teresa OÑATE \\ UNED
}

RESUMEN. Este estudio da cuenta pormenorizada -documental e interpretativa - de la referencia presocrática en la obra de H.-G. Gadamer, quien por esta vía prosigue la senda trazada por F. Hölderlin, F. Nierzsche y M. Heidegger hacia Eine andere Anfang (otro inicio) de Europa y de Occidente. Planteamiento que comporta la necesidad de examinar varias cuestiones relativas al método, la verdad y la necesidad de tal tarea del pensar, entendida como prioridad ontológico-práctica de la hermenéutica, en relación a la filosofía y la teología de la historia. Las complejas nociones que ha de poner en juego -a la vez que las interpreta siguiendo a Gadamer- son el Eterno Retorno y la Diferencia Ontológica.

Se divide en dos partes: en la que precede se estudia el Eterno Retorno como método de la verdad, lo cual entraña un giro ontológico-estético del espacio-tiempo intralingüístico, sin el cual no es posible comprender la esencial proveniencia y destino de la hermenéutica postmoderna después de Hegel. El discurso se retrotrae hasta el límite de nuestra memoria que ofrece el Poema de Parménides, precisamente consagrado a discutir los caminos (méthodoi) que conducen a la verdad (alétheia) o a su pérdida, ya por errancia infinita, ya por cierre de su ámbito diferencial modal y su articulación de ausencia-presencia a la vez. Lo mismo había dicho Heráclito, pero para comprender a ambos se ha de atravesar la restitución de la henología pluralista y la ontología modal originarias del Aristóteles griego, cuyas lecciones esotéricas de Filosofía Primera permiten cabalmente distinguir entre dos modos de ser del uno y dos ámbitos del ser que se da en el lenguaje: por un lado, el modo del acontecer (Ereignis) 
intensivo, que es propio de la acción de la verdad y su interpretación-transmisión (enérgeia kaì alétheia kaì entelécheia), $\mathrm{y}$, por el otro lado, cualquier proceso cinético-potencial o genético (kinesis, génesis). Pues sólo éstos, los movimientos, son extensos y divisibles en relación al límite. La referencia presocrática permite abrir así, de modo privilegiado y único, la vía de una aproximación al método y la verdad hermenéutica que atiende con cuidado a cómo se auto-interpreta la hermenéutica de Gadamer en cuanto tarea del pensar del ser (acción, lenguaje, sentido) en el contexto de la historia actual. Esto es: como racionalidad histórica del futuro anterior y filosofía de la historia alternativa a la Dialéctica, después de Hegel y del Andenken de Heidegger.

La segunda parte se sitúa tras la muerte del dios ilustrado y la teodicea de la historia moderna. Ahora se trata de captar cuál es la aportación original de Gadamer a la hermenéutica filosófica de los Presocráticos después de Nietzsche. En consonancia se estudia el Eterno Retorno y la Diferencia Ontológica desde el punto de vista de la selección necesaria de los pasados posibles vinculantes para nosotros, en los que se funda la hermenéutica como teología filosófica. Ahora es indispensable rememorar el nexo de Nietzsche y Heidegger con los Presocráticos para mejor comprender por qué la vía heraclítea atraviesa este decurso hasta desembocar en Gadamer, quien la radicaliza por detrás de Sócrates-Platón y la discusión de Aristóteles con el pitagorismo matematizante y escatológico de la Academia. Se trata por parte de un Gadamer-Heráclito, inédito y asombroso, de reproponer la teología noética del bien ontológico a fin de comprender la dialéctica trágica del alma del hombre y su fundada esperanza racional en la resurrección de los muertos. En conclusión a debatir, este estudio obtiene que la hermenéutica es la teología de la historia postmoderna como anámnesis de la verdad creativa. Esto es: una filosofía espiritual de la resurrección de los muertos y no sólo de los pasados posibles, sino también de las concretas voces del pensamiento que tenemos como tarea heredar e interpretar. Sólo el gran perdón del Gadamer heraclíteo permite la apertura a la inocencia de ese otro espacio-tiempo de la paz, donde no rige ya la violenta repetición de la enfermedad de la historia dictada por el espíritu de venganza. En el corazón oculto de la pietas está la ontología del amor espiritual a la diferencia posibilitante. 
A Gianni Vattimo y Jean Grondin

\section{Preámbulo: Huellas de la esperanza}

\section{Hermenéutica primera: La referencia presocrática. Contextos históricos y filosóficos después de Hegel La mismidad de la diferencia. Hasta Parménides.}

I.1. Contextos históricos y filosóficos a partir de Hegel. Aproximación a la referencia presocrática y a su actualidad para la hermenéutica filosófica.

I.2. En otro tiempo-espacio: hacia el otro inicio de Occidente. Lógos, Pietas y Sincronia: la esencial historicidad de la hermenéutica.

I.3. La hermenéutica como racionalidad dialógica de lo otro y lo posible. Pluralismo intercultural y pluralismo transhistórico.

I.4. Motivos historiográficos y filosóficos. Lo que está en juego para nosotros en la discusión de la referencia presocrática.

1.5. El limite y la diferencia. Ontologia hermenéutica de la finitud como experiencia originaria de lo uno y lo múltiple. El modo de ser acción de la verdad y el camino (méthodos) de la verdad. Remontarse desde Heidegger y Aristóteles hasta lo mismo (tò autó) de Parménides de Elea.

\section{Hermenéutica segunda: El origen espiritual del lenguaje y la historia. Problemas filosóficos a partir de Nietzsche. La diferencia de la diferencia. Hasta Heráclito.}

II.1. Nietzsche, Heidegger y Gadamer con los presocráticos.

II.1.a. Nietzsche y los presocráticos.

II.1.b. Heidegger y los presocráticos.

II.1.c. Gadamer y los presocráticos.

II.2.a. Textos presocráticos de Gadamer.

II.2.b. La vía de Gadamer: el bien ontológico. Del conflicto entre Aristóteles y Platón a los presocráticos.

II. 3. La bermenéutica como filosofia del eterno retorno: el devenir del ser.

II.4. El cruce tensional de la diferencia: dialéctica del alma y resurrección trágica.

II.5. La Anámnesis creativa: Gadamer y Heráclito por detrás de Platón. La Teología de Gadamer: la virtud productiva de la esperanza hermenéutica.

\section{Bibliografia. Textos presocráticos de Gadamer}




\section{Preámbulo: Huellas de la esperanza}

\section{PROMETEO-ESPERANZA EN HESIOODO}

El mito de Prometeo aparece dos veces en Hesíodo, primero en la Teogonia, vv. 507-616 y después en Trabajos y Dias, vv. 43-105, pero es en la segunda narración, más tardía, donde se pretende explicar la causa de que los mortales padezcan una serie de males a lo largo de su breve existencia, entre los que se incluye la esperanza.

"Pandora es un «bello mal», un presente ambiguo y dañino, contrapeso de los posibles beneficios del fuego y sus técnicas. (Hay una divergencia notoria entre los dos relatos hesiódicos: en la Teogonia es Pandora misma, en cuanto mujer, el mal personificado en cuanto origen del género femenino, productor de desdichas sin cuento; en Trabajos y Dias Pandora causa la difusión de los males al abrir la tapa de una jarra que lleva consigo)».(Carlos García Gual, Prometeo: mito y tragedia. Editorial Hiperión. Madrid 1979, p.35).

"El caso es que antes vivían sobre la tierra las tribus de los hombres lejos de los males, tanto del duro trabajo como de las angustiosas enfermedades, que acarrean a los hombres la muerte. Pero la mujer al levantar con sus manos la gran tapa de la tinaja los diseminó y a los hombres les aportó calamidades terribles.

Sola quedó alli dentro la Esperanza entre las compactas paredes de la jarra, por debajo de sus bordes, y no salíó volando hacia la puerta, pues antes cayó la tapadera de la tinaja [por voluntad de Zeus portador de la égida y amontonador de nubes]».

(Hesíodo, Trabajos y Días, v. 90-99).

\section{PROMETEO-ESPERANZA EN ESQUILO}

"CORO: ¿`No será que te precipitaste aún más en tales propósitos?

PROMETEO: Impedí a los mortales el prever su destino (la muerte).

CORO: ¿Qué remedio encontraste para esa enfermedad? 


\section{PROMETEO: Hice morar en ellos ciegas esperanzas.}

CORO: Precioso don ofreciste a los mortales.

PROMETEO: Pero además de eso les regalé el fuego.

CORO: ¿Y ahora los efímeros poseen el fuego resplandeciente?

PROMETEO: De él aprenderán muchas artes».

(Esquilo, Prometeo encadenado, vv. 247-254)

\section{EI MITO DE PROMETEO EN EL PROTÁGORAS DE PLATÓN (RELA- TO DEL SOFISTA PROTÁGORAS EN DISCUSIÓN CON SÓCRATES).}

"Era un tiempo en el que existían los dioses, pero no las especies mortales. (d) Cuando a éstas les llegó, marcado por el destino, el tiempo de la génesis, los dioses las modelaron en las entrañas de la tierra, mezclando tierra, fuego y cuantas materias se combinan con fuego y tierra. Cuando se disponían sacarlas a la luz, mandaron a Prometeo y a Epimeteo que las revistiesen de facultades distribuyéndolas convenientemente entre ellas. Epimeteo pidió a Prometeo que le permitiese a él hacer la distribución. "Una vez yo haya hecho la distribución, dijo, tú la supervisas». Con este permiso comienza a distribuir. Al distribuir, a unos les proporcionaba fuerza, pero no rapidez, (e) en tanto que revestía de rapidez a otras más débiles. Dotaba de armas a unas en tanto que para aquellas a las que daba una naturaleza inerme, ideaba otra facultad para su salvación. A las que daba un cuerpo pequeño, les dotaba de alas para huir o de escondrijos para guarecerse, en tanto que a las que daba un cuerpo grande, (321 a) precisamente mediante él, las salvaba.

De este modo equitativo iba distribuyendo las restantes facultades. Y las ideaba tomando la precaución de que ninguna especie fuese aniquilada. Cuando les suministró los medios para evitar las destrucciones mutuas, ideó defensas contra el rigor de las estaciones enviadas por Zeus: las cubrió con pelo espeso y piel gruesa, aptos para protegerse del frío invernal y del calor ardiente, $y$, además, para que cuando fueran a acostarse, les sirvieran de abrigo natural y adecuado a cada cual. (b) A unas les puso en los pies cascos y a otras, piel gruesa sin sangre. Después de esto, suministró alimentos distintos a cada una: a unas, hierbas de la tierra; a otras, frutos de los árboles; y a otras, raíces. Y hubo especies a las que permitió alimentarse con la carne de 
otros animales. Concedió a aquéllas escasa descendencia, y a éstos, devorados por aquéllas, gran fecundidad, procurando, así, salvar la especie.

Pero como Epimeteo no era del todo sabio, gastó, sin darse cuenta, (c) todas las facultades en los brutos. Pero quedaba aún sin equipar la especie humana y no sabía qué hacer. Hallándose en este trance, llega Prometeo para supervisar la distribución. Ve a todos los animales armoniosamente equipados y al hombre, en cambio, desnudo, sin calzado, sin abrigo e inerme. Y ya era inminente el día señalado por el destino en el que el hombre debía salir de la tierra a la luz. Ante la imposibilidad de encontrar un medio de salvación para el hombre, (d) Prometeo roba a Hefesto y a Atenea la sabiduría de las artes junto con el fuego (ya que sin el fuego era imposible que aquélla fuese adquirida por nadie o resultase útil) y se la ofrece, así, como regalo al hombre. Con ella recibió el hombre la sabiduría para conservar su vida, pero no recibió la sabiduría política, porque estaba en poder de Zeus y a Prometeo no le estaba permitido acceder a la mansión de Zeus, en la acrópolis, a cuya entrada había dos guardianes terribles. Pero entró furtivamente al taller común de Atenea y Hefesto (e) en el que practican juntos sus artes y, robando el arte del fuego de Hefesto y las demás de Atenea, se las dio al hombre. Y, debido a esto, el hombre adquiere los recursos necesarios para la vida, (322 a) pero sobre Prometeo, por culpa de Epimeteo, recayó luego, según se cuenta, el castigo de robo.

El hombre, una vez que participó de una porción divina, fue el único de los animales que, a causa de este parentesco divino, primeramente reconoció a los dioses y comenzó a erigir altares e imágenes de dioses. Luego, adquirió rápidamente el arte de articular sonidos vocales y nombres, e inventó viviendas, vestidos, calzado, abrigos, alimentos de la tierra. Equipados de este modo, (b) los hombres vivían al principio dispersos y no había ciudades, siendo así aniquilados por las fieras, al ser en todo más débiles que ellas. El arte que profesaban constituía un medio adecuado para alimentarse, pero insuficiente para la guerra contra las fieras, porque no poseían aún el arte de la política, del que el de la guerra es una parte. Buscaron la forma de reunirse y salvarse construyendo ciudades, pero, una vez reunidos, se ultrajaban entre sí por no poseer el arte de la política, de modo que, al dispersarse de nuevo, perecían. (c) 
Entonces Zeus, temiendo que nuestra especie quedase exterminada por completo, envió a Hermes para que llevase a los hombres el pudor y la justicia, a fin de que rigiesen las ciudades la armonia y los lazos comunes de amistad.

Preguntó, entonces, Hermes a Zeus la forma de repartir la justicia y el pudor entre los hombres: "¿Las distribuyo como fueron distribuidas las demás artes? Pues éstas fueron distribuidas así: con un solo hombre que posea el arte de la medicina, basta para tratar a muchos, legos en la materia; y lo mismo ocurre con los demás profesionales. (d) ¿Reparto así la justicia y el pudor entre los hombres, o bien las distribuyo entre todos?». "Entre todos, respondió Zeus; y que todos participen de ellas; porque si participan de ellas sólo unos pocos, como ocurre con las demás artes, jamás habrá ciudades. Además, establecerás en mi nombre esta ley: que todo aquél que sea incapaz de participar del pudor y de la justicia sea eliminado, como una peste, de la ciudad».

Ahí tienes, Sócrates, por qué los atenienses, al igual que los demás pueblos, cuando deliberan sobre la virtud en arquitectura o en cualquier otra profesión, sólo a unos pocos les consideran con derecho a dar consejos. (e) Y si alguien que no sea de éstos se pone a dar consejos, no le toleran, como tú dices, y con razón, añado yo. Pero cuando se ponen a deliberar sobre la virtud política, (323 a) toda la cual deben abordar con justicia y sensatez, entonces escuchan, y con razón, a todo el mundo, como suponiendo que todos deben participar de esta virtud o, de lo contrario, no habría ciudades. Esta es, Sócrates, la causa de tal comportamiento".

(Nuestro subrayado). John Burnet: Platonis Opera, recognovit brevique adnotatione critica instruxit Ioannes Burnet. Oxonii: E Typographeo Clarendoniano, 1957, 1967. Scriptorum Classicorum Bibliotheca Oxoniensis).

\section{HERÁCLITO DE ÉFESO}

"eàn mè élpetai anélpiston ouk exeurései» (DK 22 B 18).

Si uno no espera no encontrará tampoco lo inesperado. 


\section{H.-G. GADAMER}

"Es gracias a la esperanza que lo que aparece, precisamente porque era imprevisible y parecía inalcanzable, pudo presentarse de un modo totalmente diferente a lo que se esperaba. Entonces puede haber una sorpresa, podría baber un cumplimiento. Sólo al que tiene esperanza se le puede enviar lo inesperado" (Der Anfang des Wissens).

\section{Hermenéutica primera: La referencia presocrática}

\section{I.1. Contextos históricos y filosóficos a partir de Hegel. Aproximación a la referencia presocrática y a su actualidad para la bermenéutica filosófica.}

Al igual que en el caso de su maestro Martin Heidegger, la referencia a la filosofía inicial de los Presocráticos resulta una referencia central y privilegiada para la Hermenéutica de Hans-Georg Gadamer. Por lo que ambos, Heidegger y Gadamer, prosiguen entonces, por esta vía, la senda señalada clamorosamente por Nietzsche y abierta ya antes, desde la poesía filosófica de Hölderlin, a favor de hacer posible a partir de remontarse a los orígenes de Europa eine andere Anfang (un inicio diverso) de Occidente ${ }^{\prime}$.

No debe olvidarse, así mismo, cómo Hegel contribuyera también con influjo y poderío a una insólita actualidad de los filosofos pre-socráticos ${ }^{2}$ y en especial de Heráclito, a quien - como se recordará- se ufanaba Hegel, en las Lecciones sobre la historia de la filosofia, de haber incluido por completo, aforismo a aforismo, integrándolo en su propia Dialéctica ${ }^{3}$.

${ }^{1}$ Véase de M. HeidegGer: Beiträge zur Philosophie (Vom Ereignis). Ed. Vittorio Klostermann, Frankfurt, 1989.

${ }^{2}$ G.W.F. HEGEL: Vorlesungen über die Geschichte der Philosophie. Gesamtausgabe, Berlín, $1832-$ 45, vol. I, pp. 117-121.

${ }^{3}$ H-G. GADAMER comenta en sus I Presocratici, que forman parte del volumen primero de la obra Questioni di Storiografia filosofica. La storia della filosofia attraverso $i$ suoi interpreti (Vittorio Mathieu (ed), La Scuola, Brescia, 1975), lo siguiente: «En efecto, la fuerza sintética de Hegel y de su pensamiento le permite reconocer en los inicios la verdad especulativa, en cuyo despliegue -a sus ojos- consistía la tarea de la filosofía y de su único método científico: la dialéctica. Sin embargo, con eso y con todo, los inicios no dejaban de ser para él eso: meros inicios (...). Además de en sus Lecciones de Historia de la Filosofia, la contribución de los Presocráticos se deja sentir 
Ni tampoco la atención prestada por Schleiermacher a los filósofos preplatónicos, exigiendo que la hermenéutica de sus textos viniera a operarse desde una óptica lingüística inmanentemente griega. Lo cual, en este preciso punto, exigía sobre todo evitar la acostumbrada proyección de los prejuicios propios de la religión cristiano-semita - y en especial de los debidos a su particular concepción de lo divino- sobre los originarios documentos griegos que han conseguido llegar hasta nosotros como valiosos fragmentos conservados ${ }^{4}$.

sobre todo en su Lógica: no sólo Heráclito y la dialéctica eleática de ser y nada, sino del mismo modo, la filosofía pitagórica del uno, de lo múltiple y de la medida, son reproducidas sistemáticamente en el primer volumen de la Lógica hegeliana, viniendo a constituir, de acuerdo con una suerte de lógica históricamente necesaria, el presupuesto de la lógica de la esencia, tanto de la dialéctica platónica como de la metafísica aristotélica. (...) Lo cierto es que Hegel, ya a partir de sus consideraciones introductorias a la filosofía griega, ha dicho mucho a favor de conseguir para la filosofía griega, comprendidos sus inicios presocráticos, una actualidad filosófica que ésta no había tenido jamás, y que desde entonces ya nunca más se ha vuelto a perder". Nuestra traducción, $o p$. cit., p. 32. Y a continuación cita Gadamer extensas páginas de los referidos textos de Hegel, para darle la palabra a Hegel y facilitar que el lector, justo en ese momento, pueda escuchar e interpretar por sí mismo cómo lo ha dicho Hegel y qué está leyendo Gadamer. Pues sólo así, sin necesidad de tener que fiarse de ninguna autoridad perentoria, puede formarse el lector una opinión por sí mismo y pensar por sí mismo, dejando que fluyan libremente la conversación y sus resonancias en la imaginación mental; mientras las palabras van buscando sus propios caminos. Gracias a esa contra-dogmática dimensión criticista y estrictamente académica de "las referencias textuales» en "las citas", se cumple también la cortesía dialogal de la hermenéutica, dando lugar, por ejemplo, al tesoro patrimonial de la tradición indirecta para el rescate de tantos textos y pensamientos perdidos. En ella se expresa la liberalidad dialógica del filosofar que para siempre moldeara la mayéutica de Sócrates, en cuyo mismo espíritu participa hoy la hermenéutica gadameriana que lo hereda. Sin ella, sin la mayéutica hermenéutica dialogal, no hay sencillamente Filosofia, porque no puede darse, sin ella, la vida libre del común filosofar. En nuestra opinión la «Universalidad de la Hermenéutica» ha de entenderse desde estos parámetros. Cfr. Verdad y Método, trad. española de Ana Agud y Rafael de Agapito, ed. Sígueme, Salamanca, 1977, pp. 567-585. Wahrheit und Methode. Grundzüge einer Philosophischen Hermeneutik. Gesammelte Werke 1: Hermeneutik 1, ed. Mohr Siebeck, Tübingen, 1960/1990, pp. 478-494.

${ }^{4}$ Dice Schleiermacher citado por Gadamer: «¿De qué parte se debe colocar a Anaximandro entre los que han filosofado: con Dios o sin Dios? Algunos excluyen sin más que haya admitido un Dios porque en ninguna parte se da para él una potencia consciente como guía providente. Otros generosamente lo afirman obligados por la frase que más se le atribuye, según la cual el principio sería «divino" porque es inmortal e incorruptible. Y habrían podido añadir aquello que Simplicio observa acerca del pasaje de Aristóteles que refiere aquellas palabras: «No es nada extraño que Anaximandro haya llamado 'divino' a su infinito, sino del todo natural, queriendo indicar con esto que Dios se encuentra todavía por encima de eso 'divino' que participa de Dios" (De Vit. Pyth., segm. 11 y 12). Está claro, sin embargo, que del pasaje de Aristóteles no se puede obtener nada parecido, ni ninguna presuposición, ni nada por encima de la divinidad. Simplicio razona en base 
Fue precisamente un discípulo de Schleiermacher, Heinrich Ritter, perteneciente a la escuela histórica junto con August Brandis y Eduard Zeller, quien denominara al pensar de los primeros filósofos, desde Tales de Mileto en el siglo VI a C. hasta Anaxágoras de Clazómenes, el consejero político de Perícles en la Atenas del siglo V, o Demócrito de Abdera, el atomista contemporáneo de Platón, con una frase historiográfica que ha hecho tanta fortuna como para resultar hoy una expresión de validez canónica universal: "La Filosofia presocrática»" Así lo refiere el propio Gadamer en un documento de extraordinario interés, bien elocuente además a la hora de atestiguar la centralidad de Los Presocráticos

a la palabra "divino", pero ya en el libro III no tiene el escrúpulo de distinguir las palabras exactas de Anaximandro y de repensarlas en función del contexto. Se limita, muy superficialmente, a culpabilizarlo. (...) Sin embargo, sí su infinito comprendía en sí la posibilidad de todos los opuestos, ya que todos se diferenciaban a partir de él, también la oposición entre consciente e inconsciente debía serle extraña, ya que su esencia originaria representaba la indiferencia de estos opuestos igual que la de todos los otros. Que, sin embargo, la conciencia, tal como nos es dada en la experiencia, se encuentre necesariamente en forma de oposición, y que sólo en este ámbito se pueda oponer a lo inconsciente, resulta claro a todos. Más valdría, por tanto, que no acusemos ni a Anaximandro ni a los que como él piensen, de ateísmo, porque la acusación podría, con parejo derecho, volver a recaer sobre nosotros, desde su punto de vista, cuando nos acusaran de privilegiar un lado de la oposición respecto del otron. Pasaje proveniente de la Conferencia sobre Anaximandro de Schleiermacher, pronunciada el 11 de noviembre de 1811. Citado por Gadamer: I Presocratici, op. cit., pp. 26-27. Nuestra trad.

Y Gadamer comenta: «El pasaje me parece especialmente significativo del modo en que el sentido histórico de Schleiermacher se propone disciplinar los similares prejuicios dogmáticos derivados de la teología cristiana que tanto han enturbiado discusiones semejantes (...). En el campo de la filosofia presocrática, caracterizada por una tradición toda ella indirecta, la crítica histórica resultaba particularmente compleja y estaba destinada más a descubrir que a confirmar (...) es sorprendente, en efecto, ver con qué maestría, desde el principio, sabe moverse Friedrich Schleiermacher en un terreno tan difícil para la crítica filológica. Sus primeras memorias académicas le fueron sin duda dictadas por la necesidad de darse a conocer en los círculos eruditos de la Academia Prusiana de las Ciencias como teólogo de sólida y rigurosa doctrina. Estos trabajos nos brindan una excelente documentación del efecto intensamente estimulante que Schleiermacher imprimió al estudio de la filosofla presocrática. Dio lugar a espléndidos frutos ya en Heinrich Ritter ya en August Brandis y después en E. Zeller. Schleiermacher domina las fuentes de toda la tradición doxográfica gracias a un estudio directo y abandona con plena conciencia los esquemas de los antiguos biógrafos. Su intención es la de hacer visibles los inicios reales del pensamiento griego con el auxilio de la crítica histórica» (ibíd., pp. 27, 23-24). Y Gadamer continúa citando literalmente páginas enteras de F. Schleiermacher, de H. Rirter, de A. Brandis y de E. Zeller (ibíd., pp. 23-41). Sólo con el dualismo kantiano de Zeller, proyectado sobre los presocráticos, resulta Gadamer particularmente crítico.

${ }^{5}$ Ibíd., pp. 39-40. Véase sobre Ritter, Brandis y Zeller: ibíd., pp. 24-32; 36-41. 
en la Hermenéutica del filósofo ${ }^{6}$, tanto como la autoridad que la Academia internacional le reconoce en calidad de especialista en la materia. Es en esta Historia Hermenéutica de la Filosofía, que por si sola serviría de muestra para contestar a la pregunta "¿Qué es y qué hace, por ejemplo, la Hermenéutica?», tanto desde un punto de vista pragmático como paradigmático, donde se ha encomendado al profesor H-G. Gadamer la basta y erudita lección con que se abre el plan entero de los libros: la lección sobre "Los Presocráticos»"

' Se trata de la Historia historiográfica de la Filosofía, dirigida y editada por Vitorio Mathieu: Questioni di Storiografia Filosofica. La storia della filosofia attraverso $i$ suoi interpreti, op. cit. Colección eminente de la que estamos ofreciendo algunos pasajes debido a su importancia insoslayable para un estudio hermenéutico de Gadamer y Los Presocráticos. En efecto, se trata de una magna obra colectiva en la cual Gadamer comparece el primero ocupándose de Los Presocráticos. La monumental empresa se divide en dos grandes secciones: I: "Delle Origine All' Ottocento" y II: "Il Pensiero Contemporáneo». Entrambas secciones se estructuran después dando lugar a cinco volúmenes. Véase también sobre Hegel y Schleiermacher lectores y receptores de los Presocráticos, en la interpretación de Gadamer: El inicio de la filosofia occidental. Trad. española de Ramón Díez y Carmen Blanco, Paidós, Barcelona, 1995, pp. 14-17, donde Gadamer pone fin a la referencia del comentario sobre este mismo punto con unas enigmáticas palabras: «El misterio del inicio tiene muchos aspectos especulativos y merece la pena profundizar en sus implicaciones (...) es como el misterio del tiempo, también muy presente en la dialéctica de Aristóteles», op. cit., p. 17.

${ }^{7}$ La Lección hermenéutica de Gadamer sobre Los Presocráticos a través de sus intérpretes antiguos y contemporáneos ocupa de la página 13 a la 86 del vol. 1. La Lección de Gadamer es una verdadera lección de hermenéutica y de buen hacer filosófico. Constituye un documento único de extraordinario valor que permite medir la talla profesoral de un Gadamer erudito, profundamente coherente y siempre equilibrado a la hora de seleccionar lo pertinente de los documentos y comentarios tanto traídos como interpretados por su propio magisterio. Pero, dicho esto, lo más interesante está quizá en advertir cómo realiza por sí misma, esta Lección de Gadamer, una ejemplar historia hermenéutica del pensamiento contemporáneo desde el romanticismo hasta Gadamer mismo, pasando por Hegel, Nietzsche, Reinhardt, Bultman, De Vogel, Jaeger, Heidegger... y otras muchas voces sobresalientes, que se van reuniendo, mientras su propio entrelazado muestra, de manera indirecta y espectacular, cómo el pensamiento ontológico occidental después de Hegel se constituye precisamente a través de un contrastado diálogo permanente con la interpretación de la filosofía inicial de los presocráticos premetafisicos.

Además, claro está, de desautorizar de paso, esta Lectio, en general, la crasa ignorancia tanto de las lecturas historicistas como de las positivistas de Los filósofos Presocráticos. Las cuales sencillamente han proyectado con dogmática facilidad sobre los primeros filósofos cierta elemental modernidad anglosajona, típica más bien del XIX burgués, y a expensas de la dimensión ontológica y religiosa desde la que sí puede escucharse el propio lenguaje de los antiguos. Dice Gadamer en relación a la obra de J. Barnet The early greek phylosophie (London, 1908): "Representa tanto una época como una creencia cultural. Barnet se instituye, por así decirlo, en el apologeta de los méritos científicos de los antiguos pensadores, relegando decididamente el aspecto metafísico-religioso (...) Igual que Th. Gomperz, quien no tiene escrúpulo alguno en modernizar a estos pri- 
Ello permite entender, en orden a los presupuestos que se han de considerar y tener en cuenta a la hora de abordar la problemática concernida por la conjunción de Gadamer y Los Presocráticos, que el reverso de la pregunta anterior se pueda verter ahora en éstas: "¿Qué es la Historia de la Filosofía para la Hermenéurica?", y "Cuál es la manera de hacer Historia de la Hermenéutica?» ${ }^{8}$ Cuestiones que se responden en el texto de Gadamer de facto y de iure a través de una sin par empresa de criticismo académico riguroso, cuya praxis dialogal se vierte en la comprensión y discusión pluralista de los documentos a interpretar; los cuales, para empezar, se han de fijar merced a la misma rememoración de los Éndo$x a$, es decir: de las opiniones y las interpretaciones autorizadas, que han ido configurando la Wirkungsgeschichte, la historia efectual y documental, en este caso, de la unidad historiográfica que denominamos Filosofia presocrática. Otorgando con ello al matiz polémico contra-socrático y antes de lo socrático, ya el carácter de una provocación, ya el de una pregunta, que se ha de explorar y perseguir hasta Aristóteles y su discusión con el pitagorismo matematizante de Platón?.

Doxografía, interpretación y filosofía son tan inseparables, pues, del criticismo hermenéutico, como lo muestra la propia materia del pensar critico, que no es otra que la de sus textos, en cuanto se les de-vuelve la vida. En cuanto se les permite la resurrección inmortal que les corresponde como posibles eternos, con sólo abrirles la puerta de la lectura dialogal y de la discusión culta en interlocu-

meros filósofos griegos con gran desenvoltura», ibíd., p. 47. Y más adelante comentando, por contraste, la valiosa aportación de F.M. Conford con las obras Principium Sapientiae, The origin of Greek Phylosophical Thaught, London 1952, y la muy conocida Plato and Parmenides, London, 1939, 2." ed., 1964, insiste Gadamer con humor: "Claramente los estudiosos ingleses buscan ahora corregir la unilateralidad de la interpretación de Burnet. Conford, desde luego, lo hace explícitamente", ibíd., p. 71 (nuestra trad.). ¿Habrá que recordarles todo esto a los profesores y filólogos que se dicen especialistas en filosofía griega?

8 Ténganse presente a este respecto en todo momento el segundo capítulo de la segunda sección de Verdad y Método, a saber: los Fundamentos para una teoría de la experiencia hermenéutica, epígrafes 9, 10, 11, pp. 331-458. Y, en especial, el parágrafo 2 del epígrafe 10, pp. 383-396 de la ed. española.

9 Dice Gadamer: «El Inizio es una categoría historiográfica. Hacer comenzar la historia de la filosofia con Tales es de por sí un enunciado historiográfico y muestra que en este momento comienza a formarse una imagen histórica. Platón y Aristóteles lo demuestran entre ambos, cada uno a su modo (...). Aristóteles en particular, en quien se debe ver, para empezar, al platónico interesado en presentar a Platón como a un pitagórico y por eso como a un pensador unilateral y necesitado de ser completado con los modos de pensar más antiguos». I Presocratici, op. cit., pp. 16, 19. Nuestra trad. 
ción plural, porque se les vuelve a dar la palabra: se les deja entrar en el juego que ellos mismos abren con todas las exigencias filológicas e históricas que su propio ser determinado y finito comporta, a la vez que lo demanda y requiere de modo preciso, para sencillamente poder lograr aparecer. Un modo tan preciso como para dejarles ser otra vez ellos mismos, de diferente manera ahora, y no cualquier mamarracho, primero colonizado y luego despreciable (omisible y olvidable), que, en cualquier caso, hubiera de resultar un instrumento - ¿además inservible?- para nosotros en el presente ${ }^{10}$. No, en el corazón de la Hermenéutica está la Pietas filosófica.

\subsection{En otro tiempo-espacio: hacia el otro inicio de Occidente. Lógos, Pietas y Sincronia: la esencial historicidad de la hermenéutica.}

La esencial historicidad de la hermenéutica no remite, entonces, ni a la tradición idealizada del Romanticismo, ni a la violenta historia de los pasados guillotinados. No prosigue la rentable historia muerta de los pasados sometidos que lleva a cabo la Historia progresista de la Dialéctica de la Superación (Aufhebung)

${ }^{10}$ Escribe Heinrich Ritter en su Geschichte der Philosophie (1834-53) con tono de cuento romántico: «Hubo un tiempo en el que se pensaba que el filósofo tenía poca o ninguna necesidad de erudición, debiendo pensarlo todo por sí mismo. Era el tiempo en que se estaba más preocupado por librarse de los antiguos prejuicios, las antiguas doctrinas y hasta los antiguos derechos y normas, que no por conservar y mejorar lo antiguo. Esta opinión produjo una generación autóctona que desdeńaba conocer o venerar a los progenitores y quería ser sabia de un modo nuevo. Dónde vaya a llegar esa generación ya lo veremos pero será difícil que lo comprendan los posteriores. Por lo que a nosotros respecta, desde luego que no despreciamos la enseñanza de nuestros predecesores: lo que han conseguido, pensado o hecho para nosotros aquellos innovadores. Nos sentimos orgullosos de haber escuchado doctrinas que tienen milenios (...). Una instrucción profunda de la Antigüedad solo la recibimos si nos decidimos de cuando en cuando a retirarnos de la vida presente y a buscar la antigüedad por sí misma. Solo este método permite situarse a distancia del presente y entablar una relación profunda con el presente mismon. Citado por Gadamer, ibíd., p. 28 (Nuestra trad.). Sin embargo, como es bien sabido, para Gadamer el Romanticismo invierte y realiza la otra cara de la Ilustración al relacionarse con los prejuicios del pasado de modo tan acrítico, por incondicionalmente afirmativo, como lo hace la ilustración merced al prejuicio nuclear de rechazar incondicionalmente todo prejuicio. Ambas posturas totalizantes $y$ "formales" se hurtan del trabajo concreto de discernir entre "malos" prejuicios y, digamos "buenas costumbres o hábitos", que se debe operar críticamente en cada caso, y, sobre todo, en el análisis de las propias $\mathrm{e}$ inevitables precomprensiones epocales y lingüísticas, precisamente para no proyectarlas sin más sobre lo otro. Cfr. Gadamer: Verdad y Método, op. cit., pp. 335-350. 
hegeliana, en la época del esclavismo colonial de Europa y los Estados Unidos, internamente legitimados por las Revoluciones (la americana, la francesa, la rusa...). Pero sí se hinca firmemente en el Espíritu Objetivo de Hegel, devuelto, por otra parte, al ámbito del criticismo institucional político de la ciudadanía competente. Lo cual en el caso concreto que nos ocupa no hace sino traducirse en el ámbito de la academia culta, $y$ la independencia de espíritu de la universidad, sin cuya relativa paz institucional y social toda hermenéutica histórica habría de desembocar en manos de los intereses demasiado violentos de las instancias político-sociales dominantes: las que administran, a partir de la Ilustración, la fuerza autoafirmativa y emancipatoria de los sujetos en proceso de lucha de clases por la liberación y aseguramiento sociológico de su propio sujeto alienado y ascendente ${ }^{11}$.

11 La tesis de Gadamer es en estas páginas (ibíd., 335-350) de una rotunda coherencia: tanto la ilustración racionalista como la Ilustración romántica, las dos caras de la Ilustración moderna, sostienen y suponen un razón absoluta, la una como Razón-Libertad o liberación de la autoridad de la tradición, la otra como Razón-Naturaleza o naturalización de la autoridad de la tradición. Para la nueva hermenéutica, por contraste, la mediación entre libertad y naturaleza de la razón se articula precisamente en la historicidad de la racionalidad finita cuya crítica de los absolutos separados se centra, por un lado, en denunciar la hipostasiada separación (absolutización) de cada uno de los relacionales, y por el otro, en ponerlos efectivamente en comunicación. Gadamer sigue en esto, una vez más, exactamente el procedimiento de Aristoteles en los libros B y ( de los Metafisicos, donde la Filosofía se abre paso por entre la Sofística de la Libertad y la Dialéctica de la única Razón Universal, reconstruyendo las aporías resultantes de su mutua oposición absoluta, al mediar entre ellas y ponerlas en comunicación o enlazarlas, por en medio, por medio del lenguaje que se dice. O sea: a partir de la crítica y establecimiento de los Éndoxa u opiniones autorizadas, que son las más razonables desde el punto de vista histórico-lingüístico de cualquier comunidad políticocultural. A partir de ahí, situados los problemas precisos, a discutir e investigar, empieza el juego de acuerdo con las leyes, convenciones y reglas del lenguaje, admitidas por la mayoría. Empieza el juego, concreto y finito en cada caso, de la investigación de la verdad de los problemas que ha acumulado esa precisa tradición histórica. Véase mi libro Para leer la Metafisica de Aristóteles en el siglo XXI, ed. Dykinson, Madrid, 2001, Sección Primera, epígrafe 1.9.2-1.10: "La recusación aristotélica del pensar antitético-reductivo. Análisis de las aporías Séptima y Octava del libro B...Comentario y Conclusiones", pp. 42-66; y Sección Segunda, epígrafe 2.1 y 2.2.: "Mapa doxográfico-temático del aristotelismo contemporáneo. Escalas y método hermenéutico", pp. 66-92.

Por otro lado, que el mesótes sea el lógos común de Heráclito no es tampoco extraño, ni en Aristóteles ni en Gadamer, a la dimensión de "enlace» o «unidad diferencial» que Heidegger ha conseguido desvelar para el Lógos de la hermenéutica actual. En nuestros días quién mejor lo ha visto siguiendo a Gadamer es Pierre Aubenque en su El problema del ser en Aristóteles. (Véase para una documentación y discusión matizada del problema en Gadamer y Aubenque mi estudio "Pierre Aubenque: proximidad y distancia del Aristóteles dialéctico", aparecido en Ángel Álvarez y Rafael M. Castro (eds.): En torno a Aristóteles. Universidad de Santiago de Compostela, 1998, pp. 67-117. 
La esencial historicidad crítica de la Pietas hermenéutica reclama, así, la independencia de criterio que sólo se obtiene con el análisis y asumpción de los propios prejuicios e intereses, porque la racionalidad hermenéutica es insoslayablemente filosófica. Y la filosofía, para serlo, necesita del libre diálogo vivo filosófico, que a partir de los textos acontece tanto en el aula, o allí donde se de la discusión, como en el remanso de la biblioteca donde se albergan los textos eminentes del pasado de nuestra memoria abierta. Sin esa articulación diacrónico-sincrónica de la memoria productiva es difícil ejercer ninguna crítica eficaz del presente en profundidad, capaz de permitir que sí se abra algún futuro diferencial, alterando eso que W. Benjamin llamaba «los tiempos que corren" ${ }^{12}$. Ello no significa que la hermenéutica, la filosofía y la universidad no tengan vocación política, muy al contrario. Lo que significa es que ha de pensarse y hacerse la pólis no como un campo de batalla (de todos contra todos), ni como un mercado de concurrencias dinamizantes, sino como el lugar público-monumental que posibilita y pone en circulación las instituciones propicias para la paz civil, las artes, la cultura superior comunitaria, la paideia y la amistad. Significa que la hermenéutica está esencialmente vinculada a la pólis, y que hace la pólis desde la paideía de los lenguajes y las artes liberales, atendiendo a otros parámetros que no son los del mero vivir, sino los sí constituyentes de la ciudadanía. Que no son los de la mera sobrevivencia, la fuerza y el ascenso social de la competición concurrente por el poder, sino los parámetros determinantes del logos, del vivir-bien, por y para el bien común, como ya enseñaban, desde la fundación misma de la Academia y el Liceo los lógoi éticos y políticos del platónico Aristóteles ${ }^{13}$. Es decir:

${ }^{12}$ Dice Gadamer: «La fe romántica en las «tradiciones que nos han llegado», ante las que debería callar toda razón, es, en el fondo igual de prejuiciosa que la ilustrada. En realidad la tradición siempre es también un momento de la libertad y de la historia. Aun la tradición más auténtica y venerable no se realiza, naturalmente, en virtud de la capacidad de permanencia de lo que de algún modo ya está dado, sino que necesita ser afirmada, asumida y cultivada. La tradición es esencialmente conservación, y como tal nunca deja de estar presente en los cambios históricos. La conservación es un acto de la razón que se caracteriza por no atraer la atención sobre sí. (...) en todo caso, la conservación representa una conducta tan libre como la transformación y la innovación. La crítica ilustrada a la tradición, igual que su rehabilitación romántica, queda por lo tanto muy por detrás de su verdadero ser histórico.... el de sentirse interpelado por la tradición misman. Verdad y Método. op. cit., pp. 349-350.

13 Aristóteles: Ética a Nicómaco, K-10. Citado por Gadamer en este mismo contexto: Verdad y Método, op. cit., p. 349, nota 23. También de Gadamer: “Fenomenología del ritual y del lenguaje» en Mito y razón. Paidós, Barcelona, 1997, pp. 73-98, donde se encontrará una muy original - y conocedora- reflexión de Gadamer sobre el lenguaje en Aristóteles. 
que la hermenéutica pone (y re-conoce) también internamente la prioridad racional común del lógos como lugar diferencial y signo distintivo del encuentro de sus muy diversas declinaciones. $\mathrm{Y}$ es ese mismo logos su único criterio. El criterio preferencial que se orienta a atender en primer lugar las exigencias insoslayables del lógos como razón común y patrimonio de la paz civil, tendente a una cultura crítica y estética para todos/as ${ }^{14}$. Tal es el lugar temporal de la hermenéutica: el del cruce documental e historiográfico donde se da lugar a la interpretación de la amplitud abierta del presente, fluyendo entre los otros pasados posibles y los otros futuros posibles de nuestra memoria virtual. En ese lugar, en el lugar del lógos y la pólis dialogan y discuten los tiempos, alterándose entre sí y entrando en conversación también sus diferentes hermenéuticas críticas: desde Platón y Aristóteles, Sócrates y los presocráticos, hasta Hölderlin, Nietzsche, Heidegger, Benjamin, Gadamer, Deleuze, Vattimo... y un amplio nosotros ${ }^{15}$.

$Y$ ¿no se abre así el presente a poder ser alterado por la riqueza de las resonancias de su propio cuerpo-memoria extremo, logrando la posibilidad efectiva de poder ser algo más que una mera repetición sin sentido? ¿No se abre el presente precisamente a partir de la actualización de los lenguajes en que ya era posible hacia lo imprevisible e inaudito? Y ¡ ¡ómo si no? Porque ¿no se abre así únicamente el presente a la posibilidad efectiva de ser-mejor de lo que ya era desde

${ }^{14}$ Conviene releer la III sección de Verdad y Método («El lenguaje como hilo conductor del giro ontológico de la hermenéutican, op. cit., pp. 461-586) a favor de comprender por qué la hermenéutica actual puede auto-considerarse como una ontología política y una ontología estética, que explicita la dimensión de la intralingüisticidad griega de todo lo que puede ser comprendido, siguiendo así la contextuación inmanente de todo (lo humano y la naturaleza) en el lenguaje hablado por la cultura de la pólis (incluida su dimensión normativa). O sea: tal y como la entendían los griegos y concretamente Aristóteles, en los textos metafísicos, éticos, en los políticos, en los poéticos y en los retóricos. Véase de Franco Volpi: «Réhabilitation de la philosophie pratique et neoaristotélismem, en P. Aubenque (éd.), Aristote politique, P.U.F., París, 1993, pp. 461-484. Pero claro está que también es éste el caso de Platón, de quien Gadamer comenta: «Para él es evidente que la esencia verdadera, el ser verdadero, se revela en el lenguaje, que también está siempre determinado", El inicio de la Filosofia occidentah op. cit., pp. 65. Véase a este propósito y al de la famosa expresión de Gadamer "El ser que puede ser comprendido es lenguaje», la edición en castellano preparada con el mismo título por el estudioso Antonio Gómez Ramos, a partir del 100 cumpleaños de Gadamer (ed. Síntesis, Madrid, 2001). En este libro se recogen varios artículos-comentarios sobre la célebre frase. Entre los "comentaristas", reunidos en Heidelberg el 11 de febrero del 2000 para acompañar a Gadamer, destacaban Gianni Vattimo y Richard Rorty.

${ }^{15}$ Véase mi prólogo "Los hijos de Nietzsche" a la edición española del libro de Gianni Vattimo: Diálogo con Nietzsche. Ed. Paidós, Barcelona, 2002. 
entonces posible ${ }^{16}$ ? Pero entonces, ¿desde cuándo? ¿Qué límite hermenéutico, doxográfico y crítico-racional, precisa esa distancia y esa referencia del ser-ahí para nosotros los occidentales del siglo XXI? ¿Puede ser otro que el de la referencia presocrática aquel que tense la máxima distancia ${ }^{17}$ ?

Bien, pues de eso se trata en el caso de Heidegger y de Gadamer, siguiendo de distinta manera a Nietzsche sobre la senda curva de Hölderlin. De cómo el otro inicio no está más allá ni viene después del presente, como si no hubiéramos

16 Dice Gadamer: "Determinar de nuevo el significado de lo investigado es y sigue siendo la única realización auténtica de la tarea histórica. Sin embargo, el significado se encuentra no sólo al final de tal investigación sino también en su comienzo: como elección del tema de investigación, como estímulo del interés investigador, como obtención de un nuevo planteamiento (...). Es verdad que nuestro interés se orienta hacia la cosa, pero ésta sólo adquiere vida a través del aspecto bajo el cual nos es mostrada. Admitimos que en diferentes momentos o desde puntos de vista diferentes la cosa se representa históricamente bajo aspectos también distintos. Aceptamos también que esos aspectos no son meramente superados en el curso continuado de la investigación progresista, sino que son como condiciones que se excluyen entre sí y que existen cada una por su lado, pero que sólo en nosotros llegan a converger. Lo que satisface a nuestra conciencia histórica es siempre una pluralidad de voces en las cuales resuena el pasado. Éste sólo aparece en la multiplicidad de dichas voces: tal es la esencia de la tradición de la que participamos y queremos participar». Verdad y Método, op. cit., pp. 350-352. "En las ciencias del espíritu el interés investigador que se vuelve hacia la tradición está motivado de una manera especial por el presente y sus intereses. Sólo en la motivación del planteamiento llegan a constituirse el tema y el objeto de la investigación». Ibíd., p. 353.

17 Sigue Gadamer: «A la dialéctica de la interpretación le ha precedido ya siempre la dialéctica de pregunta y respuesta. Es la dialéctica de pregunta y respuesta la que determina la comprensión como un acontecer. De estas consideraciones se deduce que la hermenéutica no puede conocer un problema del comienzo, como lo conoce, por ejemplo, la lógica hegeliana bajo el tema del comienzo de la ciencia. Para ella el problema del comienzo se plantee cómo y dónde se plantee, es siempre en realidad el problema del final, pues es desde el final desde donde el comienzo se determina como comienzo del final. Bajo el presupuesto del saber infinito, de la dialéctica especulativa, esto llevaría al problema irresoluble del principio (...) en esta realización circular la pregunta especulativa por el comienzo de la ciencia filosófica se plantea básica y fundamentalmente desde su consumación. Cosa muy distinta es la conciencia de la historia efectual en la que tiene su cumplimiento la experiencia hermenéutica. Ella conoce el carácter interminablemente abierto del acontecer del sentido en el que participa. Por supuesto, también aquí cada comprensión tiene un patrón por el que se mide y, en consecuencia, un posible acabamiento: es el contenido mismo de la tradición el que proporciona el baremo único y el que se da a sí mismo acceso al lenguaje. Pero no es posible una conciencia - lo hemos destacado repetidamente y en esto reposa la historicidad del comprender - por infinita que fuese, en la que la "cosa» transmitida pudiera aparecer a la luz de la eternidad. Toda apropiación de la tradición es histórica y distinta de las otras, y eso no quiere decir que cada una no sea más que una acepción distorsionada de aquella: cada una es realmente la experiencia de un «aspecto» de la cosa misma». Verdad y Método, op. cit., p. 565. 
advertido ya de modo suficiente que las metafísicas de la salvación se secularizan en las utopías escatológicas del Uno-Todo ideal siempre inalcanzable a partir de sus siempre insuficientes partes reales. "Todo" ya dado, o perdido, o tachado, o hasta declarado imposible, pero siempre conservado aún como principio ideal operativo, como ideal regulativo asintótico, por el utopismo de la razón absolutista incomprensiva. La que es propia aún de las dialécticas negativas y sus infinitas tierras prometidas, siempre después, siempre más allá...

No, gracias, basta ya de dialéctica inconclusa, de modernidad siempre inacabada y de violencia salvadora contra el tiempo-lugar del ahí del ser. El otro inicio de Occidente ha de situarse, por todo lo dicho hasta el momento, en el ámbito sincrónico de la radical finitud de los límites que corresponde al Lógos de la era hermenéutica, como racionalidad y como epocalidad diferencial de Occidente. O sea: en el espacio-tiempo plural de un aquí y un ahora posibles que se relacionan de modo vivo y libre con los pasados posibles e inagotables: con los pasados necesario-contingentes y pendientes de las interpretaciones que logren vehicular y sí permitan acceder a los ámbitos plurales de lo no-dicho y no-pensado dentro de los pliegues de lo dicho y pensado por el lenguaje que habla en los otros-mismos documentos de nuestra memoria virtual ${ }^{18}$. Por eso la noción de sincronía le es esencial a la Pietas legislativa y jurídica de la radical historicidad hermenéutica, que, en uno de sus sentidos más vindicativos, vendría a reclamar, desde la phrónesis (prudencia, comprensión) como sabiduría de los límites, la igualdad entre los tiempos; la isonomía y la dike (justicia) de todos los lenguajes de todos los tiempos diferentes entre sí. Aquí y ahora abiertos ya, por el lado de su posibilidad imprevisible e inagotable.

No cabe duda de que también para el diálogo intercultural es ésta la mejor vía, la de empeñarse en la productividad del lenguaje para las praxis comunicativas del sentido: en el arte, en la literatura, en la cultura viva, en los lenguajes en acción de la interpretación y el diálogo crítico contra todo dogmatismo brutal o elemental, a favor de aislar y debilitar y dislocar o re-escribir, distorsionada irónicamente, la perentoria seriedad del monólogo único e impositivo del $\operatorname{poder}^{19}$.

18 Véase mi libro dedicado al filósofo Gianni Vattimo: El retorno de lo divino griego en la Postmodernidad. Una discusión con la hermenéutica nibilista de Gianni Vattimo. Ed. Alderabán, Madrid, 2000. Y, sobre todo, la larga intervención de Vattimo en la Entrevista filosófica del Postfacio: Ontologia y Nibilismo, ibid, pp. 200-238.

${ }_{19}$ Ninguno de los discípulos de Gadamer ha insistido con tanta efectividad y dedicación en la radical condición de pertenencia a la paz civil de la hermenéutica histórica como el maestro para 
Ésa es la mejor vía: debilitar la uniformidad e insistir en el diálogo intercultural hasta poner de relieve los inconmensurables de las diversas culturas-lenguas, precisamente a favor de las diferencias, ya que efectivamente se trata hoy de debilitar la violencia del nihilismo de la Globalización monológica, propio del capital ilimitado. Y si el esfuerzo dialogal pacifista ha de parecer ingenuo a quienes fían en la aparente rapidez de la violencia de la muerte y de la guerra, habrá que contestar una y mil veces que no es sino el espíritu de venganza lo que se repite en la enfermedad de la indiferencia de la historia, subsumiendo en la dialéctica a los amos y a los esclavos, sin que puedan distinguirse entre $\mathrm{si}^{20}$. Eso en el caso de que las antítesis subsumidas no engorden la tesis permitiendo que las diferencias terminen convirtiéndose en banderines de algún hipermercado situado a las afueras del No-Where de ninguna ciudad. Donde todos trabajan, compran y consumen, se trasladan, duermen, consumen, compran y trabajan, protestando ya sólo a favor de la optimización del funcionamiento del sistema en que han terminado por matar al Tiempo vaciado de cualquier experiencia y cualquier diferencia, mientras olvidan el olvido y repiten ¿̨confortablemente? La fuga de la muerte ${ }^{21}$.

muchos de nosotros: Gianni Vattimo. Véase para un recorrido por toda su obra desde el hilo conductor del debolismo de Vattimo, propuesto por el filósofo como criterio-límite de la interpretación contra toda violencia monológica: T. Oñate, «La contribución de Gianni Vattimo a la hermenéutica del siglo XX", en Rev. Azafea, vol. 5, Cirilo Flórez (ed.), Universidad de Salamanca, 2003.

${ }^{20}$ Resulta imposible no advertir en Heráclito un mentis aparente de este discurso, cuando dice: «La guerra es padre de todo, de todo es rey; a unos los señaló dioses, a otros hombres; a unos los hizo esclavos, a otros libres» (Hipólito, Ref. IX, DK 22 B 53). Y también: «Hay que saber que la guerra es común, que la justicia es lucha y que todo acontece por lucha y por necesidad" (Orígenes, C. Cels. VI 42. DK 22 B 80). (Nuestra trad. en T. Oñate y C. García Santos: El nacimiento de la Filosofia en Grecia. Ed. Dykinson, Madrid, 2004, p. 197). Para el comentario de Gadamer sobre estos aforismos véase El inicio de la sabiduría occidental, op. cit., pp. 66-70.

${ }^{21}$ Dice Hölderlin en su Archipiélago, versos 241-252:

"iAy de mí!, vaga errante en la noche, vive como en el Hades

Sin divinidad, nuestra progenie. A su convulso hacer

Encadenada y cada uno en el fragor del taller

Solo a sí se oye; asaz trabajan los brutos.

Con brazo poderoso, insomnes; pero para siempre

Estéril como las furias queda el sudor de los míseros.

Hasta que despoblada del sueño de angustia el alma humana

No se alcance con alegría joven y el santo hábito del amor

Como antaño no vuelva en los hijos la flor de la Hélade

A exhalar en una época nueva, y a una frente más libre,

El espíritu de la naturaleza, el dios tras tanto transmigrar

Sosegado posándose en nubes de oro de nuevo se aparezca». 
Muchos de los afectados ya no tiene ni memoria ni historia, y sólo les envuelve el presente absoluto-vaciado, repitiendo sin descanso sus iguales imágenes numéricas por las pantallas... ¿Qué puede, entonces, querer decir esa nueva pretensión según la cual las estructuras y sintaxis de los lenguajes conceptuales del Occidente crítico piensan en griego a partir de las propias categorizaciones topológicas de sus límites? ¿No sería preferible dejar a La Historia vulgar como está y celebrar que el Cristianismo venciera el cruel pasado pagano de Grecia y Roma dando lugar a un auténtico Humanismo para todos? Y, en todo caso, ¡vaya, que los muertos descansen en paz dejando sitio a los vivos! ¿Que para eso se les entierra con los rituales y plegarias pertinentes ${ }^{22}$ !

22 Conviene leer a propósito de esta reflexión, con detenimiento, un sorprendente escrito de Gadamer que ha devenido profético, nos referimos al texto: "La diversidad de las lenguas y la comprensión del mundo", compuesto justo entre la Caída del muro de Berlín y la Guerra del Golfo de 1990. Es como si el filósofo ya anticipara de modo visionario en estas páginas, la conexión de estos eventos con el atentado terrorista de las Torres Gemelas de Nueva York, del 11 de Septiembre del 2001. Se trata de un breve texto impresionante, en el cual un Gadamer de noventa años vuelve a insistir con inusitado brío, como lo hiciera toda su vida, en cómo únicamente el Diálogo, parezca débil o no, puede dar lugar a las culturas de la alteridad y el pluralismo que necesitamos en las sociedades hermenéuticas postmodernas. Sociedades del mestizaje y la comunicación de las diferencias, que han de estar a favor, no de reducir su pluri-lingüísmo sino de articular la alteridad. Dice Gadamer:

"Puesto que ya no cabe presuponer sin más un buen conocimiento de la Biblia, me permito citar a guisa de introducción, un texto del Antiguo Testamento. Es el célebre relato de la Torre de Babel. Allí se cuenta que un pueblo, que se había establecido en la región de la Mesopotamia asiática, decidió construir una gran torre que llegase hasta el cielo. Y ahí se dice:

"Y hagámonos un nombre por si nos desperdigáramos por toda la faz de la tierra». Bajó Yahvéh a ver la ciudad y la torre que habían edificado los hijos de los hombres, y dijo Yahvéh: «He aquí que todos son un solo pueblo con un mismo lenguaje, y éste es el comienzo de su obra. Ahora nada de cuanto se propongan les será imposible. ¡Ea, pues, bajemos!, y una vez allí, confundamos su lenguaje de manera que cada cual no entienda el de su prójimo." Y desde aquél punto los desperdigó Yahvéh por toda la faz de la tierra y dejaron de edificar la ciudad" (...).

¿Bajo qué nombre queremos permanecer juntos? ¿En el nombre que se tiene y que le permite a uno, por así decirlo, ya no escuchar al otro? Lo que a mí me importa es mostrar que nos enfrentamos a esta tarea: no la de querer eliminar la diversidad de las lenguas en el curso de un proceso de organización - por ejemplo por motivos de racionalización o burocratización - sino en el sentido de que cada uno aprenda a salvar las distancias y a superar los antagonismos entre nosotros. Y esto significa respetar, atender y cuidar al otro y darnos mutuamente nuevos oídos; algo de lo que carece bastante este mundo en el que se apela a los expertos (...). Todos hemos de aprender que el otro representa una determinación primaria de los límites de nuestro amor propio y de nuestro egocentrismo. Es un problema moral de alcance universal. También es un problema político. En estas semanas y meses no puedo en absoluto subrayar con suficiente seriedad cuán crucial es la 


\subsection{La hermenéutica como racionalidad dialógica de lo otro y de lo posible. Pluralismo intercultural y pluralismo transhistórico.}

Sólo que difícilmente puede haber diálogo intercultural sin diálogo intrahistórico, o transhistórico. Y ese es el reto actual de la hermenéutica postmoderna desde el punto de vista de muchos de nosotros ${ }^{23}$ : radicalizar el vector posthistórico de los pasados plurales posibles y devolverles la palabra, precisamente debido a cómo los otros pueblos y culturas, todos los no-occidentales, por ejemplo, han sido declarados y tratados como pueblos del pasado: salvajes, primitivos o menores de edad, en nombre del afán civilizatorio de la Historia Universal del Progreso Ilustrado. La misma Historia de la Civilización Universal que ha ido avanzando con supuesta legitimidad histórica durante las generaciones de la modernidad ilustrada, a lo largo de los dos pasados siglos, el XIX y el XX, como mínimo hasta la Segunda Guerra Mundial. Ha ido avanzando con supuesta legitimidad mientras vinculaba los conflictivos procesos coloniales y de des-colonización con los asombrosos logros de la ciencia-técnica, no todos tan deseables, si se ha de subrayar el potencial armamentístico de poder letal, en manos de las industrias bélicas. Un potencial tanto de alcance planetario como de rentable des-estructuración mercantilista en los deslocalizados «sistemas» del Capital, hoy ya, eso sí, letal sin fronteras. Y porque también los otros de lo humano: los dioses, lo divino y la naturaleza - - e incluso lo femenino y la infancia en cierto modo ${ }^{24}$ y hasta la filosofia, las letras y las artes, han sido catapultados al enrarecido extrañamiento del pasado irracional o menos racional de Occidente. Incluso los que están vivos son tomados por fantasmas en nombre de la triunfal Razón progre-

necesidad de aprender a conseguir una solidaridad realmente efectiva entre la diversidad de las culturas lingüísticas y de las tradiciones. Esto se logrará sólo lenta y laboriosamente y requiere que empleemos la verdadera productividad del lenguaje para entendernos. En lugar de aferrarnos obstinadamente a todos los sistemas de reglas con los que diferenciar entre correcto y falso (...). Quien escucha al otro escucha siempre a alguien que tiene su propio horizonte. Ocurre entre tú y yo la misma cosa que entre los pueblos o entre los círculos culturales o las comunidades religiosas. Por doquier nos enfrentamos al mismo problema: debemos aprender que escuchando al otro se abre el verdadero camino en el que se forma la solidaridad». En H-G. Gadamer: Arte y verdad de la palabra, trad. española de Faustino Oncina y José F. Zúniga. Ed. Paidós, Barcelona, 1993, pp. 112-126.

${ }^{23}$ Véase completa la sección "La filosofía griega en la Hermenéutica de Gadamer", dentro del libro: Hans-Georg Gadamer: Ontología estética y Hermenéutica. Ed. T. Oñate, C. G. Santos y M. A. Quintana. Dykinson, Madrid, 2005.

${ }^{24}$ Véase mi escrito "Feminismo alternativo y Postmodernidad estética", en Reflexiones sobre arte y estética. En torno a Marx, Nietzsche y Freud. Ed. José Vidal, FIM, Madrid, 1998, pp. 81-113. 
sada del Hiper Presente transparente. Pero entonces, ¿qué interlocución podrá mantenerse con lo otro y con las diferencias que no sea una interlocución con los pasados, los pretéritos o los presentes-ausentes, vuelta de alguna manera posible hacia un futuro no pre-programado y sí cada vez menos violento?

¿Cómo podrá hacerse la crítica del presente y la apertura al futuro si no es tendiendo un puente a todo lo otro abora alojado en el pasado precisamente por la dialéctica de la racionalidad moderna ilustrada, que se proyectaba progresando en línea recta hacia el Futuro libre de la Humanidad? ¿No ha mostrado ya con suficiente violencia en la experiencia histórica de las revoluciones cómo se mata el futuro al querer convertir el pasado en un horno crematorio de aquellos presentes sentenciados y ajusticiados a los que se exilia incluso con la prohibición de volver la vista atrás?

Ese es uno de los vectores más profundos que pone en juego la hermenéutica como crítica contra la violencia ahistórica de la historia universal: desenmascarar la eu-lógica (autocomplaciente) o lógica elemental identitaria de la Dialéctica de la Ilustración moderna, denunciando la contradicción de su progreso aparente en un tiempo congelado y siempre repetitivo de lo nuevo vaciado. Por eso, de manera obligada, ha de remitirse la hermenéutica a lo otro de los pasados posibles en nombre de las diferencias; reanudando el diálogo con todos los pasados no agotados para devolverles la palabra y la vida histórica que sí les permita tender un puente al presente y poder alterar el presente hacia el volver a fluir de las historicidades concretas. Se trata de una necesidad histórico-política y más precisamente, debido a su preciso planteamiento histórico, de una necesidad ontológico-política: alterar la metafisica de la historia global, para que vuelva a haber historicidades.

No es posible siquiera asomarse al significado y el sentido de la hermenéutica sin comprender que el vínculo entre los pasados posibles y la apertura a la alteridad y las diferencias, son instancias de una misma posición concreta y precisamente histórica para nosotros en los comienzos del siglo XXI: la que proviene de la modernidad y se adentra, dándose la vuelta ${ }^{25}$, por la única vía posible que que-

25 Por eso la postmodernidad no se propone como una superación de la modernidad, sino como su re-orientación crítica hacia el sentido de los límites: como su de-limitación. Que ello haya de operarse, y por qué haya de hacerse históricamente en Occidente, como una vuelta a la reinterpretación de los principios espirituales no-dogmáticos de su propia proveniencia histórica. Véase El retorno de lo divino griego en la Postmodernidad, especialmente el cap. VII y ss, op. cit., pp. 147 239. 
da para la reapertura de las historicidades finitas - concretas y diferenciales-, a fin de reabrir la crítica eficaz que sólo puede operar lo otro en el contexto de la modernidad realizada. La vía, pues, orientada hacia lo otro que sí altera y abre algún futuro diverso, insólito, no previsto, no de antemano representado ni calculable. La vía que nos ha abierto la hermenéutica al trabajar en el volver resucitado de aquello múltiple nunca efectuado, y por eso no agotado, que yace en nuestros pasados y repertorios historiográficos, documentales y lingüísticos.

Un gran río de memoria virtual que permite volver a todas esas diferencias que estaban ya allí y no se dieron. $O$ bien por no haber sido recibidas, o bien por no haber podido entrar en la combinatoria eficaz que pudiera agenciarse tal repertorio en alguna acción comunicativa suficiente. $O$ tal vez alguna de ellas sí se dio y su fulgor duró sólo un instante, antes de pasar a ser tapada por su propio cuerpo de lenguaje, volviéndose insignificante y no relevante, en medio de esa otra interpretación que la olvidaba mientras la subsumía...

Por lo general basta con que eso que llamamos «efímero" aún no haya encontrado el preciso contexto comunicativo donde hallar una superficie de inscripción o una constelación de sentido que sí haga posible su resurrección inmanente, permitiéndola volver a aparecer como diferencia, de otra manera posible. Tal es la vía lingüística, jurídica y poético-virtualizante de la apelación por parte de Gadamer a la retórica en su función de Pietas. Una Pietas sincrónica de los pasados posibles que nos devuelve a nosotros sencillamente nuestra heredad, nuestra infinita herencia, aquella de los legados a que tenemos derecho; la memoria viva del Andenken -rememorar- heideggeriano, reinscrita en el espíritu objetivo de Hegel y abierta ya por Nietzsche y por Hölderlin hacia la contingencia-posible de los pasados y su futuro anterior aquí y ahora: el que es competencia del poetizar fundacional que sabe re-nombrar y señalar ${ }^{26}$. Ésta es ahora la tarea: recibir los presentes, rememorar los pasados posibles y renombrar sus combinatorias futuras de múltiples repertorios, de acuerdo con las leyes del sentido ontológico de la verdad dialogal, cuyo último criterio-límite es el del amor espiritual a lo otro indisponible que hay

${ }^{26}$ Dice Gadamer: «La palabra poética instaura el sentido. La palabra «surge» en la poesía a partir de una fuerza de dicción nueva que con frecuencia está oculta en lo usual (...). A través de ello la palabra se vuelve más diciente y lo dicho está de un modo más esencial "ahí" (...) el "ahí" universal del ser en la palabra es el milagro del lenguaje, y la más alta posibilidad del decir consiste en retener su transcurso y su huída para fijar la cercanía del ser. Es la cercanía y la presencia no de esto o aquello, sino de la posibilidad de todo. Esto es lo que realmente caracteriza a la palabra poética. Se cumple en sí misma porque es el mantenimiento de la proximidad». "Acerca de la palabra poética", en Arte y verdad de la palabra, op. cit., pp. 43-44. 
en todo lo otro en tanto que diferencia-límite. O sea: el criterio del amor transversal al ser, o amor a la verdad-bien del otro, que se ha de buscar y hacer en cada caso, orientándose sólo hacia el darse plenamente como diferencia del otro en su propia concreción y coherencia. Pues sólo la manifestación de la diferencia de lo otro hace que pensemos y nos da que pensar, reanuda el diálogo, e instaura la serenidad intensiva del dejar ser. Y cuanto mejor sea el otro y lo otro, más plenamente diferencial e intensa su determinación, a la que quizá hayamos podido contribuir virtualizando ${ }^{27}$ la actualidad de sus posibilidades, mayor será también nuestro placer y nuestra gratitud por poder disfrutar, sencillamente, de su ser-bien así y su estar bien-así, en medio del dolor y el placer de la vida y de la creatividad intensa de sus mundos plurales. Todo esto es dialogicidad. Dialogicidad poético-trágica como esencia de lo común del lógos. $\mathrm{O}$, en otras palabras: como praxis esencial de la racionalidad interpretativa y comunicacional del lenguaje vivo cultural, en todas las culturas animadas de la tierra.

$Y_{¡}$ claro está que para todo ello hace falta hermenéutica!: traducciones, interlocuciones, intérpretes, embajadas, conocimiento de las costumbres y los espectáculos otros, de los otros dioses, y de los lenguajes en que aparecen; de los textos y de los ritos, de los cuerpos, las músicas, los silencios y los gestos; hace falta aprender a ser extranjero en la propia lengua, mientras se estudian lenguas extranjeras y remotas... Y, en fin, hace falta, en ocasiones, hasta bastante erudición crítica... ello además, claro está, de las virtudes cívicas racionales que ya antes declinábamos a partir del radical no-violento del lógos y la pólis, vistos en la conjunción de la paz civil.

Virtudes racionales ${ }^{28}$, todas las cuales pueden reconducirse, como ya lo hiciera Sócrates magistralmente en Atenas, al sentido unitario de la praxis del diá-

27 Dice Gadamer: "Conocer el principio de una cosa significa conocerla en su juventud, la fase de la vida humana en que no existen todavía los desarrollos concretos y determinados. Creo que en este sentido se ha de hablar del inicio que tiene lugar con los presocráticos (...) es sorprendente descubrir que en este inicio se abre la dimensión más importante del ser humano... la que está definida por su potencialidad, o mejor todavia "virtualidad", como prefiero decir, porque potencialidad significa siempre posibilidad de alguna realidad determinada, mientras que para mí «virtualidad" significa estar orientado hacia un futuro indefinido". El inicio de la filosofia occidental, op. cit., pp. 21-22.

${ }^{28}$ Sobre las virtudes dianoéticas y el sentido práctico del noûs en Aristóteles, véase H.-G. Gadamer: «Fenomenología del ritual y del lenguaje», op. cit., pp. 131-133. Y también "Palabra e imagen, tan verdadero tan siendo" (1992), en Estética y bermenéutica, trad. de A. Gómez Ramos. Ed. Técnos, 1996, pp. 300-303. 
logos. de la pregunta y la respuesta por el sentido de los lenguajes dados. Es verdad que Platón añadió lo que inmortalizaba el diá-logos de la areté socrática convirtiéndolo en arte literaria y dramatúrgica de la verdad del bien, mientras refundaba la hermenéutica filosófica, explicitando su esencia intralingüística y literaria, política, como vía de la dialéctica ontológica. Pero también es cierto que Aristóteles hubo de recordarle - probablemente a favor de que no se confundiera la praxis hermenéutica de la filosofía, magistralmente revelada por Platón mismo, ni con el platonismo doctrinal pitagórico, ni con ninguna doctrina filosófica o epistémica - un "hecho hermenéutico y polémico" de gran alcance, a saber: que ya antes de Sócrates, en el pasado, había nacido la Filosofía en la Jonia, en las azules costas de Mileto, recogiendo una experiencia inmemorial ${ }^{29}$.

Así nacieron los Presocráticos. Y no es el menor logro de la extraordinaria labor hermenéutica de H.-G. Gadamer el haber insistido sistemáticamente en este punto de partida: que los Presocráticos nacen en la discusión filosófica, esencial para la auto-interpretación de la filosofía europea, que mantienen entre sí Platón y Aristóteles, y para decirlo con mayor rigor aún: en la crítica de Aristóteles a su maestro Platón y en la crítica de Sócrates-Platón a los anteriores filósofos, cuya unidad de convergencia común se haya, a su vez, en la crítica de éstos, los primeros, a los mitos antropocéntricos y genésicos propios de las cosmogonías y teogonías de Homero y Hesíodo, en la época feudal de la Edad de los héroes, la violenta y arbitraria edad belicista, catapultada por el espíritu de Délfos y el Lógos del Limite Común de los Siete Sabios, entre los que se cuentan ya, significativa-

29 Dice Aristóteles: «Ha sido transmitida por los antiguos y muy remotos, en forma de mito, una tradición para los posteriores, según la cual los Primeros Principios son seres y son dioses, y lo divino (tò theînn) abarca la naturaleza entera. Lo demás ha sido añadido ya míticamente para persuadir a la multitud ya en provecho de las leyes y del bien común. Dicen, en efecto, que éstos son de forma humana o semejantes a otros animales, y otras cosas afines a éstas y parecidas a las ya dichas, de las cuales si uno separa y acepta lo verdaderamente primero, es decir que creian que las entidades primeras (tàs prótas ousías) eran dioses, pensará que está dicho divinamente, y que sin duda habiendo sido desarrolladas muchas veces, en la medida de lo posible, las distintas artes y la filosofía, y nuevamente perdidas, se han salvado hasta ahora, como reliquias suyas, estas opiniones. Así pues, sólo hasta este punto nos es manifiesta la opinión de nuestros mayores y la tradición primitiva". Metafisicos, $\Lambda$-9, $1074 \mathrm{~b}$ 1-14. Nuestra trad. (Véase un extenso comentario crítico-hermenéutico del pasaje en T. Oñate: Para leer la Metafisica de Aristóteles en el siglo XXI, op. cit., pp. 505 y ss.; dentro del epígrafe 2.5.1: "Crítica y reformulación de la lectura teológica", pp. 446-512).

Así mismo Tales de Mileto había dicho al comienzo del filosofar: "Todo está lleno de lo divinow. (Para los fragmentos atribuidos a Tales, cfr. nuestro El nacimiento de la Filosofia en Grecia. Viaje a Inicio de Occidente. Ed. Dykinson, Madrid, 2004, pp. 162-167). 
mente, tanto Solón de Atenas, el justo legislador, como Tales de Mileto: el topólogo de la tierra-celeste, el navegante de las estrellas ${ }^{30}$.

¿Y no deberemos nosotros pararnos también en ese ser-ahí nuestro: en ese límite de nuestro otro extremo, para tensar la crítica del presente de Occidente hasta su extremo otro, dejando que se tense y suene la cuerda de esa resonancia oculta y profunda, que sigue vibrando con una oculta y profunda, insondable, armonía? ${ }^{31}$ Nada mejor que hacer el viaje con el filósofo H-G. Gadamer hacia ese límite constituyente del futuro anterior del Occidente posible, gracias al enlace con la historicidad inagotable de nuestros pasados resucitados a las culturas y las tradiciones interpretativas: un viaje hermenéutico hacia ese que es nuestro límite otro, nuestro otro inicio, desde entonces, desde los Presocráticos, o como lo dice mucho mejor el maestro Gadamer: «Desde que somos una conversación ${ }^{32}$ ».

${ }^{30}$ Véase el estudio «Hacia Mileto», en El Nacimiento de la Filosofia en Grecia..., op. cit., pp. 41-147.

31 Dice Gadamer rememorando el Lógos de Heráclito como enlace o puente entre los extremos y en relación al caso-límite de la traducción de lo poético en que no puede faltar el tónos, lo siguiente:

"(...) la cuerda tensada debe temblar bajo las palabras y los sonidos, si es que ha de ser música. ¿cómo podría ser de otro modo? (...) siempre será una resonancia, un sonido con sentido, uno solo o muchos, una armonía oculta que es más sólida que otra manifiesta como sabía Heráclito... un arco sólidamente asentado, un puente transitable en ambos sentidos. La traducción es, por así decirlo, un puente entre dos lenguas como el que está tendido entre dos orillas de un mismo país...Eso es lo que distingue al traductor. No hay que esperar a ningún barquero que le conduzca a uno. Naturalmente alguno necesitará ayuda para encontrar el camino que conduce al otro lado, pero después seguirá siendo un caminante solitario. Quizá más adelante, de nuevo, encuentre a uno que le ayude a leer y a comprender". "Leer es como traducir", Arte y verdad de la palabra, op. cit., pp. 92-93. Y sobre la subitaneidad de la inversión de lo oculto en el contexto de la paradoja del cambio repentino que caracteriza la dialéctica transversal de Heráclito, comenta Gadamer: "Llego, pues, a la conclusión: no hay que referirse a modos particulares de representación. Para la tesis de la identidad de los contrarios extremos se trata de algo diferente: de la subitaneidad con la que se transforma la visión de las cosas. En verdad esto nos pone ante los ojos la oposición entre muerte y vida. Hay que interpretar toda su doctrina mirando hacia ese punto (...) lo que hay oculto en cada uno de los extremos sale ahora fuera", El inicio de la sabiduría occidental. op. cit., pp. 65 .

32 Dice Gadamer: "Hay que devolver a la Retórica la basta extensión de su validez, que le fue arrebatada en los comienzos de la modernidad por la ciencia matemática de la naturaleza y por la teoría del método. La retórica refiere a la totalidad del saber del mundo concebido linguísticamente e inserto en una comunidad lingüística (...) el concepto clásico de retórica remite a toda la convivencia y al entendimiento mutuo que discurre entre los hombres en formas simbólicas. Por lo demás el lenguaje no es solo el lenguaje de palabras. Hay el lenguaje de los ojos, el lenguaje de las 
Pero entonces, ¿qué es lo que se discute en esa conversación?, ¿qué es lo que está en juego en la centralidad para nosotros, al parecer, de volver a establecer la referencia presocrática, vía Sócrates, Platón y Aristóteles, tal y como demanda Gadamer...? ¿Se trata, quizá, de disponerse a leer a los primeros filósofos, a los Presocráticos, otra vez por vez primera, para asistir al surgimiento mismo de nuestro pensar lingüístico? ¿O tal vez también de constatar que lo que llamamos «Historia" no es siempre ya sino hermenéutica historiográfica y dialogicidad crítica? Pero... ¿y Nietzsche?, ¿y Heidegger? ¿Hacen ellos la misma lectura de los primeros filósofos que Scheleiermacher o que Gadamer, que Platón o que Aristóteles?

manos, la ostensión y la llamada. Todo esto es lenguaje y confirma que el lenguaje está siempre allí donde unos hombres se relacionan con otros. Las palabras siempre son respuestas incluso cuando son preguntas (...). En fin, hay incluso que preguntarse si las acciones simbólicas son antes que el lenguaje de palabras articulado. Pero ¿se puede hablar de antes y después si todo es conversación?...” (subrayado nuestro).

«El pensamiento es lo que pasando por encima de toda experiencia, sigue pensando y sobrepasa su propio horizonte temporal y vital en la reciprocidad de la conversación. Conocemos esto en especial por la peculiar incomprensibilidad que tiene la muerte para la conciencia vital del ser pensante, por el límite oculto que le ha sido dado (...). Cuando nuestro pensar se acerca a ese misterio, entonces se da otra experiencia, a saber: que ya no hay ninguna respuesta a nuestra pregunta. La respuesta está cerrada a cualquier experiencia, y esta es la experiencia que a uno le es participada en cualquier encuentro con la muerte de otros. Ya no se puede esperar ninguna respuesta de alguien con quien todavía hablábamos ayer. En el mundo de la convivencia hace acto de presencia lo espantoso de la ruptura de cualquier posible conversación". H.-G. Gadamer: "Acerca de la fenomenología del ritual y del lenguaje» (1992), en Mito y razón, trad. española de José F. Zúñiga. Ed. Paidós, Barcelona, 1997, pp. 77-79. Texto este de particular brillo e importancia donde Gadamer viene a proponer la hipótesis según la cual el origen mismo del lenguaje ha de situarse en las acciones simbolicas que remiten al culto a los muertos porque: "Cuando nuestro preguntar se acerca a este misterio, entonces se da otra experiencia, a saber: que ya no hay ninguna respuesta a nuestra pregunta (...). La única respuesta que nos cabe es la resistencia que ofrecemos a ello. Se comprende de golpe por qué los hombres que son una conversación y pueden oírse los unos a los otros, no pueden aceptar que haya ruptura. De modo que el pensamiento está siempre sobrepasando y devuelve, por así decir, una respuesta que ya no le es dada a uno. El que incluso la tumba sea dotada de las más preciadas prendas es una especie de indemnización. Pensando y agradeciendo los hombres dan sepultura a sus muertos; sólo los hombres lo hacen. Porque están en conversación los unos con los otros dotan a sus muertos de todo, y todos estos dones votivos son como una continuación de la conversación. En fin, quizá esto sea válido para todas nuestras acciones simbólicas, para el pensamiento y para todas las palabras que se realizan cumpliéndose a sí mismas", ibíd., pp. 79-80. 


\subsection{Motivos historiográficos y filosóficos. Lo que está en juego para nosotros en la discusión de la hermenéutica presocrática.}

Se ha de reflexionar con con mucho cuidado sobre cómo contestó Aristóteles a la pregunta socrática sobre la paideia de la virtud ${ }^{33}$, y tener en cuenta que lo hizo a través de una frase filosófica para cuyo establecimiento critico necesitó la argumentación de los catorce lógoi de Filosofía Primera (luego mal llamados libros Metafisicos). Para ello hubo de contar, además, con la ayuda de las apasionadas discusiones del De anima, vinculadas a la hermenéutica de la racionalidad y la verdad práctica que se enseña en Ética a Nicómaco. Una frase filosófica semejante a ésta: «que solo se transmite el modo de ser verdad de la virtud». Una tesis sobre la verdad ontológico-práctica de las acciones intra-lingüísticas que para poder establecerse hubo de recurrir, en todos los casos documentales mencionados, a su única prueba posible --tratándose de lo primero inderivable e indemostrable-: la confutación punto por punto de la Dialéctica platónico-pitagórica en cuanto ésta se proponía, según Aristóteles, como doctrina ontológica de los Primeros Principios, defendiendo las Ideas-Géneros Universales y las Ideas-Números como causas del ser, del conocer y del devenir. Había que reducirla al absurdo, como posición concurrente, para obtener de su confutación crítica la única apoyatura dialéctica posible para las tesis contrarias, las suyas, las de Aristóteles, que ya fueron buscadas también por Sócrates ${ }^{34}$. La frase filosófica de la respues-

${ }^{33}$ Cfr. H.-G. Gadamer: "Die sokratische Frage und Aristoteles", en Gesammelte Werke, vol. 7, pp. 373-380. Y “Aristoteles und die imperativische Ethik», en ibíd., pp. 381-395.

34 Dice Aristóteles: "Los que establecen un proceso infinito no se dan cuenta, sin embargo, de que suprimen la naturaleza del Bien. Nadie desde luego se pondría a hacer nada si no fuera a llegar a un término. Ni habría tampoco entendimiento de las cosas que son: en efecto, el que tiene entendimiento actúa siempre para algo y esto constituye un límite, pues el límite es el fin ( $t \grave{\text { gàr }}$ télos péras estin) (...). Además los que así hablan suprimen la ciencia, ya que no es posible saber antes de alcanzar lo que ya no es divisible (...). Y también es justo que la Filosofía sea llamada "ciencia de la verdad", pues no conocemos lo verdadero sin conocer la causa y en cada caso la causa es la excelencia de la propia naturaleza en virtud de la cual recibe el nombre...de suerte que cada cosa tiene verdad en la misma medida en que tiene ser". Metafisicos, a 2, 994b 12-24; a 1, 993 b 19-31. Quizá porque el texto del libro alfa minor haya sido literalmente "torturado" por las tradiciones de las Metafísicas bíblicas, conmueve aún más estremecedoramente cómo la verdad ontológica de la acción virtuosa (singular y participativo-comunitaria) que consigue atravesar la niebla de las mutilaciones seculares.

Póngase en relación con el alfa minor el texto central del libro $\Theta$ [Theta] 9-10 de los Metafisicos, que gracias al influjo de Heidegger ya ha sido admitido por la crítica académica mayoritaria 
ta de Aristóteles a Sócrates era ésta: que sólo se enseña o transmite el modo de ser de la acción-virtud (prâxis-enérgeia-aretê). Por lo que únicamente la acciónvirtud puede enseñarse verdaderamente (bos alethés) ${ }^{35}$.

Si bien la fuerza de la potencia cinética eficiente, claro está, puede lograr imponerse en el ámbito propiamente genético y motriz de la eficacia como paradigma tecnológico y mitológico, a espaldas del bien de la physis kai pólis. Es decir: a espaldas del modo de ser de la naturaleza y el lenguaje, donde tiene primacía la acción del plenamente ser y su unidad de sentido intensiva, de orientación sincrónica, sobre el movimiento potencial tentativo según el antes y el después. Así lo había establecido ya el antecedente de la crítica ontológico-lingüística de Parménides y Heráclito contra la superficial sabiduría matemática de los pitagóricos, que sólo pensaban en la salvación mitológica del alma del hombre; y así lo atestiguaba la tradición de la teología física milesia con que daba comienzo la elaboración estructural y nocional de la filosofía contra-mitológica ${ }^{36}$. O sea: que el Timeo del pitagórico Platón ya habría sido refutado por Anaximandro, al principio de la Filosofía, viniendo entonces a presentarse el Timeo, con su dios creacionista tecnológico y su cosmogonía matemática, como respuesta contra-filosófica y mito literalmente reaccionario ${ }^{37}$. Puesto que, de manera insoslayable, el

como expresión de "la verdad ontológica» o alétheia. Dice allí Aristóteles: «Así pues en las cosas que son un ser-esto-diferencial y acciones (hósa dé estin hóper eînai ti kaì enérgeiai) no es posible errar sino alcanzarlas o no (...) y la verdad consiste en alcanzarlas (tò dè alethès tò noein taûta). $Y$ aquí no cabe falsedad ni error, sino ignorancia, pero no como en la ceguera; la ceguera, en efecto, sería como si uno careciera completamente de la facultad intelectiva". Metafisicos, _-9, 1051 b, 301052a 4. Véase nuestro comentario en Para leer la Metafisica..., op. cit., pp. 622-627 y «El ser y el Pensar: Los tres sentidos de la verdad en Aristóteles», ibíd., pp. 219-235. También sobre la verdad ontológico-práctica de la acción virtuosa, poniendo en relación a Aristóteles con las preguntas de la paideía ética de Sócrates, el mencionado estudio: «Pierre Aubenque: proximidad y distancia del Aristóteles dialécrico", op. cit., pp. 67-118.

${ }^{35}$ Véase mi estudio «El criticismo aristotélico en el siglo XX: Hacia un cambio de paradigman, en Lógos, Anales del Seminario de Metafísica (1998), N. ${ }^{\circ} 1$, ed. Univ. Complutense de Madrid, pp. 251-269. Y sobre todo la discusión pormenorizada con los motivos metodológico-modernos, para decirlo con Gadamer, de la interpretación de Aubenque, en el estudio ya citado: «Pierre Aubenque: proximidad y distancia del Aristóteles dialécticon, en En torno a Aristóteles, ed. Ángel Álvarez, Universidad de Santiago de Compostela, 1999.

${ }^{36}$ Para esto y para todo lo que sigue sobre el ser del tiempo en Anaximandro de Mileto, y para el contraste entre la llamada "Sentencia de Anaximandro" y el Timeo platónico, se puede consultar el volumen ya referido: El nacimiento de la Filosofia..., en especial las secciones III, IV, V, VI del «Hacia Mileto", pp. 61-114.

${ }^{37}$ Véase en ibíd. el estudio "Parménides entre Platón y Aristóteles", desde la sección III a la $\mathrm{XI}$, ambas inclusive. En este arco discursivo se examinan crítica y pormenorizadamente todos los 
primer documento escritural de la Filosofía no contenía sino una elaboración y explicación estrictamente racional del ser-eterno del tiempo y el kósmos como confutación crítica de toda cosmogonía: de todo creacionismo mitológico-tecnológico-genésico, propio de la primitiva proyección antropocéntrica del tiempo humano-mortal o genético y sus relatos. La proyección mitológica del tiempo creado que olvidaba su ser-eterno y las leyes ontológicas del mismo, a favor de las cosmogonías y teogonías narrativas donde lo otro de lo bumano era violentamente antropomorfizado a imagen y semejanza del tiempo mortal del hombre y sus producciones tecnológicas de objetos, según el antes y el después lineal. La filosofía comenzaba con Anaximandro, apelando a la justicia (Dike) del Lógos para abrir la afirmación de eternidad del otro tiempo (con respecto al hombre): el tiempo-Ser eterno y sus posibles ausentes que son como ausencia en el Lógos con el mismo derecho que los presentes (tà ónta) ${ }^{38}$.

El ciclo necesario resultante de la disposición del tiempo (katà tèn tô̂ chrónou táxin) como alternancia entre los contrarios, prescribe así, desde Anaximandro, la ley ontológica que rige el "Principio de No-Contradicción» -que después formulará explícitamente Aristóteles en el Libro Gamma de los llamados Metafisicos - , pues no es sino la descrita estructura temporal del Kósmos la que regula la imposibilidad del darse a la vez de los contrarios relativos, en el ámbito de las generaciones y movimientos; estructura legislada por la síntesis de lo indeterminado o ilimitado (ápeiron) y el límite del tiempo, mostrando tam-

escritos del «último Platón" a partir de la crisis de la Teoría de la Ideas y la imposibilidad platónica de establecer de un modo suficientemente racional, siguiendo los propios presupuestos de su filosofia, la méthexis o participación, entre las Ideas suprasensibles y los entes sensibles. De este fracaso resulta el mito político-pitagórico del Timeo y la entronización de la mimesis matemático-tecnológica del Demiurgo, con largas consecuencias para la fundación de la Historia universal de Occidente. Véase también de Quintín Racionero: "Ciencia, retórica y política en Platón, a propósito del Mito probable de Timeo $29 \mathrm{Cm}$, incluido en el volumen En torno a Aristoteles, op. cit., pp. 355-383.

${ }^{38}$ Dice Simplicio: «Anaximandro de Mileto, hijo de Praxiades, sucesor y discípulo de Tales, dijo que el principio y elemento de los entes es lo ilimitado (tò ápeiron), siendo el primero en introducir este nombre para el primer principio. Dice que el primer principio no es agua ni ningún otro de los llamados elementos, sino alguna naturaleza distinta, ilimitada, de la que nacen todos los cielos y los mundos que hay en ellos. De donde les llega el nacimiento a los seres, hacia lo mismo les llega también la destrucción usegun la necesidad: pues se dan unos a otros justicia y pago por su injusticia según el orden del tiempo", diciéndolo así en términos bastante poéticos". Nuestra traducción. Véanse los comentarios y notas de C. García Santos a este texto en El nacimiento de la Filosofia..., op. cit., p. 169. 
bién, a la vez, que el otro ámbito del tiempo, al otro lado del límite, es el de la sincronía de las diferencias plurales sin contrario. Por eso la doxografía antigua atribuyó siempre también a Anaximandro la tesis de los infinitos (en número) mundos finitos posibles, comprendiendo que la noción de la posibilidad-necesaria cuyo cumplimiento habrá de darse o ahora o después, si es que no era imposible, está en la matriz de la legislación del Lógos-Díke con que se abre la topología del pensar del ser-tiempo y nace la Filosofía. Lo mismo que en la sentencia de Tales «Todo (Kósmos) está lleno de lo divino». O sea: de lo eterno-necesario y por eso inteligible-regular y anticipable en cuanto a los fenómenos, pendientes aquí o allá de condiciones similares, que por eso puede autoconstituirse en untodo autolegislado: un Kósmos racional.

Tal es la investigación que Gadamer reclama prosiguiendo la vía propia de la hermenéutica contemporánea abierta por Nietzsche y Heidegger, lectores de los Presocráticos después de Hegel. La vía que trata de profundizar en la cuestión de la Crítica a la Metafisica y el sentido de la Historia, respondiendo a las exigencias intempestivas que nos llaman desde esa interrogación compleja y radical. Preguntas insoslayables para nosotros que se dibujan ya, sin duda desde Hölderlin, afectando a la raíz racional de la autocrítica de la civilización occidental misma. Por eso han ido situándose en el centro de la filosofía crítica actual, pugnando por convertirse en el leit motiv de una posible alternativa-alteración del positivismo dogmático cientifista y el historicismo lineal progresista, en el marco sobredeterminado por el capital de las guerras de alcance planetario. Un discurso que ha ido abriéndose camino mientras la propia hermenéutica ha ido alterando, punto por punto, la legitimidad de estos dos grandes mitos o meta-relatos violentos, supuestamente indiscutibles y legitimadores, con los que se impone hoy en todo el mundo la única Razón Universal que se pretende para siempre hegemónica. La eficaz razón tecnocrática de Occidente que, sobre todo a partir de los procesos de secularización propios de la modernidad ilustrada, ha ido manifestándose de modo cada vez más transparente como la razón nihilista del poder y la fuerza, únicamente dirigida a su propia expansión global planetaria contra toda diferencia. Ya cultural, ya institucional. Ello en medio de la creciente pauperización del planeta, el empobrecimiento impotente de las sociedades de comunicación de masas, y la concentración del capitalismo expansivo en la gestión rentable de la barbarie belicista ${ }^{39}$.

39 Véase de Jean François Lyotard: Le Différend. Ed. Minuit, París, 1983; L'Enthousiasme. Ed. Galilée, París, 1986 y Le Postmoderne expliqué aux enfants. Correspondance 1982-1985. Ed. Ga- 
Por eso la hermenéutica se propone otro inicio mientras actúa como razón crítica y disolutoria de los fundamentos perentorios de la fuerza. Se propone como la preparación de ese otro inicio racional necesario-posible, que quizá resulte más que nunca urgente entre nosotros, ahora. Ahora, cuando el nihilismo cumplido en las sociedades del capitalismo telemático parece haber llegado - para decirlo con palabras de Heidegger- al máximo grado de emplazamiento transparente (Gestell), en el escaparate del todo-consumible ${ }^{40}$. Un emplazamiento donde todo lo colocado allí, en su estante correspondiente, resulta vaciado y dispuesto sin margen de sustracción, ocultamiento o reverso alguno, como recurso utilizable y enteramente disponible, incluidos los "recursos humanos". Pero es, sin embargo, precisamente en tal situación extrema de "la imagen del mundo", donde señala Heidegger la posibilidad de una chance para el relampaguear del Ereignis. Una surte de posibilidad otra, no decidible ni voluntaristamente construible, del acontecer del ser-lenguaje-historia. Pues rememorando el verso de Hölderlin: «Allí donde está el máximo peligro, allí crece también la salvación" ${ }^{41}$.

Mientras tanto parece haber ya algunos síntomas de esto último; parecen darse ya diversos indicios esperanzadores, de entre los cuales no sería el menor precisamente la difusa recepción actual de la racionalidad hermenéutica en Occidente y su esfera de influencia, así como la potencia constatable de lo que podríamos llamar el Efecto-Gadamer en todos los registros de la cultura crítica por todas partes.

Pues que sean nuestras actuales sociedades de la comunicación las especialmente permeables a la sensibilidad y la vindicación hermenéutica de la finitud, el límite y las diferencias, podría tal vez dar la vuelta al pensamiento único ${ }^{42}$ y gra-

lilée, París, 1986. Y de Michel Foucault: Nietzsche, la Genealogia, la Historia, trad. castellana de José Vázquez. Ed. Pre-Textos, Valencia, 1988.

${ }^{40}$ Cfr. para la filosofia del Gestell heideggeriano como chance para un relampaguear del Ereignis o Acontecer postnihilista del ser-lenguaje: "La pregunta por la técnica", en Conferencias y Artículos, trad. de E. Barjau. Ed. serbal, 2. ${ }^{2}$ ed., Barcelona, 2001, pp. 9-50, especialmente pp. 17-32.

${ }^{41}$ Y Heidegger añade, citando otra vez a Hölderlin: «Poéticamente mora el hombre en esta tierra"... cuanto más nos acerquemos al peligro, con mayor claridad empezarán a lucir los caminos que llevan a lo que salva, más intenso será nuestro preguntar. Porque el preguntar es la piedad del pensarm. Ibíd., pp. 31-32. Véanse también sobre la misma temática y reunidos en este mismo volumen, los escritos de Heidegger: "Superación de la metafísica" (pp. 51-73) y "Poéticamente habita el hombre» (pp. 139-152).

${ }^{42}$ Utilizamos la expresión ya consagrada que debemos a Ignacio Ramonet, director de la edición castellana del periódico «Le Monde Diplomatique». 
cias a una globalización plural únicamente de las tele-comunicaciones y las redes inmediatas de conexión inter-dialogal en todos los lugares, debilitar el monologismo elemental de la fuerza homogénea y el terrorismo caracterísitico de la identidad del poder, que se afirma negando lo otro. Filósofos como mi maestro Gianni Vattimo o como Michael Hardt ${ }^{43}$, por citar sólo dos ejemplos emblemáticos de la hermenéutica postmoderna, que hereda directamente a Gadamer, como es el caso de Vattimo, por un lado, y a la ontología de Deleuze y el postestructuralismo francés, como hace Hardt por el otro, son síntomas alentadores de un futuro anterior que se remite en ambos al nexo de Nietzsche. Instancias tan significativas como éstas permiten entender que las posiciones de las plurales izquierdas postmarxistas o postmodernas sí puedan enlazarse en la mínima plataforma común que hace falta: la de estar dispuestos a debilitar la violencia contra las diferencias, y a defender con eficacia la vida plural de las culturas de la paz ${ }^{44}$. Ya se ejerza esta violencia en nombre de los absolutos fundamentalistas, ya lo haga refugiándose en los relativismos indiferentes, debido a cómo tales posiciones se compensan mutuamente ofreciendo las dos caras de la misma moneda: la que hace circular la nada por todas partes en la época del nihilismo cumplido por el capitalismo ilimitado ${ }^{45}$.

43 Véase de Michael Hardt la obra sobre Gilles Deleuze que le consagrara internacionalmente: Gilles Deleuze. An Apprenticeship in Philosophy University of Minnesota 1993. Y de Juan Manuel Aragüés: Lineas de fuga contra la sociedad idiota. Ed. Fundación de Investigaciones Marxistas (FIM), Madrid, 2002. También los estupendos trabajos de de Francisco José Martínez sobre Deleuze y entre ellos, por ejemplo: “El pliegue como categoría ontológica en el pensamiento de G. Deleuze", en Gilles Deleuze, un pensamiento nómada. Coord. J.M. Araguiés. Ed. Mira, Zaragoza, 1997, pp. 23-33. Un imprescindible registro del vínculo Toni Negri- Félix Guattari puede verse en el libro Las verdades nómadas. Por nuevos espacios de libertad, trad. castellana de J. Pedro Alvite. Ed. Tercera prensa-Hirugarren, Donostia, 1996.

${ }^{44}$ Cfr. T. Oñate: "Los hijos de Nietzsche y la ontología hermenéutica de Gianni Vattimo", Prólogo a la edición castellana del libro de G. Vattimo: Diálogo con Nietzsche. Ed. Paidós, Barcelona, 2002.

45 Esa es una de las tesis decisivas tanto de Gianni Vattimo como de H.-G. Gadamer y de M. Heidegger. Véase de Vattimo, por ejemplo: Dopo la cristianita. Per un cristianisimo non religioso. Ed. Garzanti, Roma, 2002. De Martin Heidegger un texto emblemático contra la violencia: «Superación de la Metafísica" en Conferencias y Artículos, op. cit., pp. 51-75. El volumen entero es una joya. Y contiene lo que podríamos llamar El Heidegger medio (para contraponerlo a la división entre el primer y el segundo Heidegger). Un Heidegger maduro y sumamente lúcido que no puede ser reintegrado ni al humanismo metafísico ni a la apofática mística de las teologías negativas del ser. Un Heidegger que da la pauta para su propia hermenéutica ofreciendo en estas páginas un compendio excepcional de todo su pensamiento. En Cuanto a H.-G. Gadamer, y en relación a esta 
Pero se ha de insistir en la esperanza de esa otra racionalidad que es la hermenéutica, pues mientras tanto... ¿ No se ha convertido ya la hermenéutica de Gadamer en la nueva koiné racional - diciéndolo con Gianni Vattimo- de las sociedades de Occidente no sólo en Europa sino también en América - singularmente en América latina- y algunos otros lugares repartidos por todos los continentes ${ }^{46}$ ? ¿No es la hermenéutica esa nueva lengua común que nos permite discurtir y pensar ahora, posibilitando tanto la crítica actual de la cultura como la filosofía de las diferencias? Puede que éstas se articulen en el diálogo y conversación que se orientan al encuentro plural; y puede también que el disenso racional se obtenga como registro de las conversaciones. Pero en los dos casos es la racionalidad hermenéutica la posibilitante de una interlocución abierta por la alteridad. Así pues, si se trata con Gadamer de estudiar a los filósofos presocráticos no es sino para conocer diferencialmente cuál sea de modo matizado su posición respecto de las cuestiones y problemas suscitados por la racionalidad histórico-hermenéutica del otro inicio. $\mathrm{O}$ sea: para responder al reto que desde la procedencia nietzscheana de aquel "no hay hechos sino interpretaciones" nos espolea con el dardo del eterno retorno, después de la muerte de Dios que proclamara Hegel. Y ello bajo la consigna nietzscheana de invertir el platonismo de la historia de Occidente (como núcleo de continuidad del desenvolvimiento de la metafísica platónico-cristiana-secularizada y realizada por su misma historia). Lo cual equivale a señalar que se trata de dar lugar a la reproposición de una cultura trágico-estética y a la trans-valoración de la lógica de

misma temática, pueden leerse los escritos recogidos en La herencia de Europa, trad. castellana de Pilar Giralt. Ed. Península, Barcelona, 1990, con una Introducción de Emilio Lledó dedicada a Gadamer: «El testigo del siglo».

${ }^{46}$ Véase de G. Vartimo: «Hermenéutica nueva Koiné», en Ética de la interpretación, trad. castellana de Teresa Oñate. Ed. Paidós, 1991, pp. 55-73. Dice Gianni Vattimo:

«Decir que la hermenéutica sea tal koiné sostiene sólo, desde el punto de vista de la descripción factual, que así como en el pasado gran parte de las discusiones filosóficas, o de crítica literaria, o de metodología de las ciencias humanas, tenían que rendir cuentas al marxismo o al estructuralismo, sin que por ello tuvieran que aceptar sus tesis, como sucedía a menudo, así hoy la hermenéutica parece haber asumido esa misma posición central. En el momento de la publicación de Verdad y Método de Gadamer (1960), "hermenéutica» era un término especializado que designaba aún, para la cultura común, una disciplina particular ligada a la interpretación de los textos literarios, jurídicos o teológicos; hoy el término ha adquirido, sin embargo, un significado filosófico mucho más amplio y central... pero tal constatación se vuelve menos genérica si, además de referir una situación, se buscan las posibles razones de esa actualidad de la hermenéutica...n, op. cit., pp. 55-56 y ss. 
los valores de los esclavos — siempre típicos del resentimiento en pos de su liberación o emancipación o salvación-; que se trata de dislocar la época decadente que entronizaran ciertas lecturas de Sócrates, «el alucinado del tras-mundo", y de Eurípides - sigue Nietzsche-. Aquellas reducciones aseguradoras que confluyeron en la inauguración del racionalismo del cálculo moral con que se daba muerte tanto a la cultura de la paideía estética de la tragedia como a aquella filosofía que sí había florecido en la época trágica de los griegos: la filosofía pre-socrática ${ }^{47}$.

Éstos son, pues, varios de los motivos racionales que entran en juego en la discusión sobre Los Presocráticos, en curso por todas partes en las Facultades de Filosofía y los lugares de arte y cultura crítica en Occidente ${ }^{48}$. Y si hacía falta recordarlos no era sino para evitar desde el principio la equivocada opinión posible consistente en creer que el filósofo H.-G. Gadamer haya estudiado tan rigurosamente a los Presocráticos con ánimo erudito, inventarial, o de mero conocimiento filológico y especializado de los fragmentos antiguos. Eso también lo ha hecho, desde luego, metodológicamente, pero con el fin hermenéutico de posibilitar su verdad actual. O sea: que los más antiguos de nuestros textos, y la más distante-tensa de nuestras memorias documentales, irrumpan en la experiencia del pensar actual de la verdad, que se pone en juego al preguntar y responder por su sentido. Intentando comprender y escuchar su sentido. Ya que sólo permitiendo y posibilitando (virtualizando) que los textos otros sean leídos desde ellos mismos y desde su alteridad, en el mayor grado intensivo de lo posible, pueden éstos volver a la interlocución dialogal y a la discusión de los problemas que ellos mismos permiten, permitiéndonos a nosotros, a nuestra vez, pensar de otra mane$r a$ el pasado y futuro del presente.

${ }^{47}$ F. Nietzsche: La filosofia en la época trágica de los griegos. Ed. Valdemar, Madrid, 1999, especialmente pp. 38-44. Y de Gadamer, para la contraposición «Metafísica científica" y "Ontología»: El inicio de la filosofia occidental, op. cit., "El sentido del inicio", pp.13-23 y especialmente p. 20.

${ }^{48}$ Véase mi trabajo «Occidente y el problema del ser. Una conversación con Pierre Aubenque en Madrid", en Revista de Filosofia., 3. 'Época, vol. VI (1993), N. ${ }^{\circ}$ 9, Univers. Complutense de Madrid, pp. 207-219. Para un amplio repertorio bibliográfico del criticismo presocrático contemporáneo véase la bibliografía seleccionada en El nacimiento de la Filosofia..., op. cit. 


\subsection{El límite y la diferencia: ontologia hermenéutica de la finitud como expe-} riencia originaria de lo uno y lo múltiple. El modo de ser-acción de la verdad y el camino (méthodos) de la verdad. Remontarse desde Heidegger y Aristóteles hasta lo mismo (tò autó) en Parménides de Elea.

...De otra manera gracias a la diferencia. Pues sólo ésta da qué pensar, al interrumpir la habitual repetición del reconocimiento y asignación de lo nuevo dado, en las casillas de ordenación ya previstas, ya disponibles. De otra manera que no se parece en nada a la integración subsumida en el presente, sino que ofrece la aventura del verdadero pensar. el que sale al encuentro de lo desconocido con toda la radicalidad posible abierta por la diferencia en la que insiste y en pos de la cual se lanza. La Diferencia acaecida en el lenguaje de los otros y por el lenguaje de los otros, que comienza por operar la crítica de las insuficiencias del presente y de lo dado acostumbrado, orientándose hacia la concreción de sus otras posibilidades no realizadas: las que pueden alterarlo, cada vez, y hacerlo mejor.

Nunca ha habido hermenéutica sin intempestividad y extrañamiento del presente, $y$, desde ese punto de vista, que no es sino el de la experiencia viva de la filosofía y del filosofar, se puede entender bastante bien que Gadamer haya insistido tan a menudo en la "Universalidad" de la Hermenéutica, si bien precisando que no se trata de la Universalidad del "Todo y las Partes" de ningún esquema extenso o cuantitativo, al modo de las cantidades lógicas y sus inclusiones predicativas de carácter holista-merológico, sino del modo de la convergencia de mismidad intensiva en un universo musical de resonancias, muy cercano al Bien-Uno ontológico platónico del plenamente ser que tienen en común las Ideas, o mejor dicho: las Diferencias-acciones simples - tal como corregirá Aristóteles- por participar en ese modo mismo de ser ${ }^{49}$.

Un uni-verso que se pone en juego en toda acción comunicativa, agenciándose todas las piezas: los interlocutores, el guión, el espacio-tiempo, y las estructuras lingüísticas; los enunciados correctos o verosímiles, los gestos, las maneras, los cuerpos y el estilo ${ }^{50} . .$. , con tal de irrumpir en el ámbito de encuentro -el

${ }^{49}$ Cfr. H.-G. Gadamer: Die Idee des Guten zwischen Plato und Aristoteles, Sitzungsberichte der Heidelberg Akademie der Wissenschaften, Heidelberg, 1978.

50 Véanse de Gadamer sobre la relación entre Teatro, Acción comunicativa y Paideía cuatro escritos apasionantes referidos a la densa problemática de la Oralidad/Escritura en el "Platón educador". Se trata de los siguientes: Plato und die Dichter, Wissenschaft und Gegenwart n. 5, Klostermann Verlag, Frankfurt am Main 1934; Platos Staat der Erziehung, en Das neue Bild der 
disenso crítico es posterior, primero tiene que darse la acción dialogal - de esa experiencia del pensar que llamamos "verdad ontológica» con un antiguo y venerable término de Heráclito, Parménides, Platón y Aristóteles: alétheia: «desvelamiento" o "descubrimiento». El que marca el significante gracias al alfa privativa que deniega y conserva lo denegado mientras lo escribe aún en la léthe, de a-létheia, signando así que en el des-velamiento «algo» irrumpe de lo velado, mistérico, callado y tapado, que sigue ahí, que irrumpe, acontece y emerge también ahí y se experimenta porque aparece ahí, como tal misterio: en medio de la plaza pública, del ágora, del teatro, de la obra de arte, o del aula de filosofía ${ }^{51}$. A la vez lo des(velado) y lo velado por lo des(velado)..., en la sincronía de convergencia simple cuyo síntoma inequívoco es la ciclicidad, el retorno o la re-flexividad propia de lo sin partes extensas... porque es modalmente intensivo y sin imagen visual. Gadamer ha insistido enfáticamente en la importancia central del «se» reflexivo que corresponde como marca distintiva a todo lo vivo dotado de alma. Tal es el leit motiv de sus "Estudios heraclíteos» en El inicio de la sabiduría occidenta $f^{2}$. En efecto, lo que distingue la vida-alma de los objetos técnicos como realizaciones de conceptos es que las acciones espontáneas y autolegisladas del alma no son meros movimientos, para decirlo de un modo sencillo, debido a la reflexividad inmanente implicada en todos los procesos propios de las vidas cuyas

Antike, ed. H. Berve, Leipzig, 1942; Dialektik und Sophistik im siebenten platonischen Brief, Sitzungsberichte der Heidelberg Akademie der Wissenschaften, Heidelberg, 1964; y Amicus Plato magis amica veritas, publicado por primera vez con ocasión de la segunda edición del libro: Platos dialektische Ethik. Felix Meiner Verlag, Hamburg, 1968.

${ }^{51}$ Así lo cuenta, de modo inolvidable, el estudioso francés Jean Pierre Vernant en Los orígenes del pensamiento griego. Trad. Castellana de Mariano Ayerra. Ed. Paidós, Barcelona, 1992, pp. 6195, especialmente p. 70 y ss. Conviene, por otra parte, reparar en el contraste que ofrecen entre sí las nociones de «revelación" y «descubrimiento» o «desvelación». Las religiones dogmáticas se instauran a partir de "verdades reveladas" mientras que la verdad de la hermenéutica es ella misma la acción de desvelar junto con sus condiciones de posibilidad lingüísticas, espacio-temporales y contextuales.

${ }^{52}$ H.-G. Gadamer, El inicio de La sabiduria..., op. cit, pp. 31-85. Una explicación magistral de la diferencia ontologica trazada por la verdad ontológico-práctico-modal, que ya descubriera la teoría de la enérgeia de Aristóteles como acción-verdad-transmisión, se encuentra en otro de los textos sorprendentes del Gadamer de noventa años. Probablemente el Gadamer más lucido, profundo y brillante que nos haya regalado su escritura a lo largo de todas las décadas de sus cien años bien cumplidos. Se trata del escrito cabalmente aristotélico: «Palabra e imagen "Tan verdadero, tan siendo" " (1992), con el que se cierra la colección contenida en el libro Estética y hermenéutica, op. cit., pp. 279-307, especialmente pp. 293-303. 
subjetualidades resultan afectadas y transformadas, de modo decisivo y diferencial, por esos mismos procesos suyos de auto-alteración y expresión: los de la acción que revierte sobre sí misma.

El régimen temporal, espacial y racional de los lenguajes de la vida es enteramente diverso, por tanto, del régimen de lo cósico: su movimiento y su quietud. Pero ya Aristóteles había centrado en la diferencia del modo de ser temporal y espacial que se da entre kinesis y enérgeia (movimiento extenso, por un lado, y acción intensiva, reflexiva, verdadera y comunicativa, por el otro) toda su crítica del platonismo matematizante, encerrado en los conceptos y sus medidas. $Y$ ello precisamente en orden a diferenciar los lenguajes de la vida, propios de la physis kaì pólis - y también del arte poética (poíesis), sobre todo trágica- respecto de los ámbitos cinéticos de carácter lógico y tecnológico. Pues si estos últimos no retornan ni son espontáneos, es porque no son fines de sí mismos, y, en consecuencia, nunca pueden exhibir el característico modo de ser a la vez que es propio de la simultaneidad consigo mismas de las acciones simbólicas vivas. Porque lo mismo es a la vez ver y haber visto, pensar y haber pensado, vivir y haber vivido..., tal y como enseña Aristóteles con precisión en el lógos IX de los Metafisicos. Una sincronía diferencial modal que Gadamer retoma también como modo de ser de la verdad ontológica, siguiendo en esto muy de cerca a Heidegger en la asumpción de la enérgeia kaì alétheia kaì entelécheia (la acción y verdad [desvelamiento] y transmisión) de Aristóteles. Gadamer nombra la misma sincronía diferencial de esta manera: "el desocultamiento de lo que emerge y está guardado en la obra misman ${ }^{53}$.

Los lugares privilegiados, entre otros muchos, dentro del Corpus aristotelicum para el estudio de ésta, que es la diferencia ontológica para Aristóteles (o sea: la diferencia entre acción energética y movimiento potencial) son éstos: dentro de los Lógoi metafisicos, el libro VII (dedicado al alma como "próte aitía toû eînaì o "primera causa del ser»), el libro IX (dedicado a la modalidad potencial y/o activa) y el libro X (dedicado a la henología de lo uno y lo múltiple, lo mismo y lo otro, etc.). Pero además se han de tener en cuenta de manera central las teorías de la recusación del infinito y la afirmación del placer extático, no cinético, contenidas en los Lógoi fisicos, la Etica a Nicómaco y el De anima, por ejemplo ${ }^{54}$.

53 Ibíd., p. 297.

54 También en el lógos a minor de los metafisicos, donde Aristóteles la pone explícitamente en conexión con el eterno retorno como méthodos del pensar que es propio de la verdad ontológica. 
Pues ninguna de estas colecciones lectivas que son prioritarias para la comprensión del Aristóteles griego redescubierto tanto por la labor del criticismo académico como por la racionalidad hermenéutica, puede entenderse en absoluto si no se traza la diferencia ontológica y la distinción de ámbitos linguísticos y modales que ella implica; así como, de manera decisiva, no puede comprenderse sin ella nada de la crítica que Aristóteles dirige a Platón.

Su importancia es tanta, en resumen, que sin tener en cuenta que tal diferencia preside, atraviesa y recorre todos los circuitos del lenguaje de Aristóteles, no se puede llegar a entrar siquiera en la menor urdimbre de su auténtico pensamiento. El cual, a medida que ha ido siendo descubierto por la hermenéutica del siglo $\mathrm{XX}-\mathrm{y}$ desenterrado por debajo de las múltiples capas de versiones y transformaciones que se lo apropiaban y lo adaptaban a las culturas nacidas de la Biblia y sus secularizaciones- ha ido alentando en la racionalidad de la interpretación misma el incomparable giro vital y espiritual que la hermenéutica actual de la filosofía griega transmite ahora a todos los ámbitos del saber y de la cultura occidental. Cuya problematización crítica, en particular, se ha ido poniendo en obra gracias a la figura bien precisa que corresponde, en todas sus declinaciones posibles, a una crítica delimitación griega de la Ilustración moderna. La cual, sin duda, tiene mucho que ver con la Diferencia Ontológica no entendida, por eso, al estilo de los monoteísmos y los monologismos, como si se tratara de una diferencia entre El Ser (en singular) y los Entes (en plural), sino entendida propiamente como la diferencia de ámbitos intensivo (de lo ser) y extenso (de lo ente), que corresponde respectivamente a los lenguajes de las acciones extáticaslímite y los lenguajes de los movimientos dinámicos referenciales. Tal es uno de los casos clave donde se registra el esencial papel que desempeña la filosofía griega, a partir de Hölderlin y de Nietzsche, en la hermenéutica. En fecto, no puede ignorarse cómo lo inscribe la ontología crítico-histórica del An-denken elaborada por el Segundo Heidegger, y cómo lo pone en acción la hermenéutica

Para una detallada documentación y discusión de los textos de Aristóteles véase mi trabajo: Para leer la Metafisica de Aristóteles en el siglo XXI. op. cit, especialmente Libro Segundo, Sección Primera, caps. 1.4 y 1.5: "Substancia, esencia e individuo: el eîdos-alma como causa primera" (pp. 187219) y "Relación entre los dos compuestos —individual y universal— por subordinación al eidoscausal. El ser y el pensar: los tres sentidos de la verdad en Aristóteles" (pp. 219-236); así como Libro Tercero, Sección Segunda, cap. 2.3 y 2.4: “El pròs hén entre la substancia sensible y la suprasensible. La filosofía modal en relación al ente y su unidad (pp. 416-461) y "Conclusiones" (pp. 261-266). 
filosófica con que Gadamer continúa el pensar de la Diferencia Ontológica hasta nosotros: rehabilitando la racionalidad noética y la intuición o experiencia intelectual de la verdad práctico-estética interpretativa, en el ámbito de las ciencias del espíritu ${ }^{55}$. J. Habermas, interesado interlocutor de Gadamer, hace justicia a Aristóteles cuando denomina a las enérgeiai y entelécheiai "acciones comunicativas", pero difumina el ámbito tan costosamente reabierto por la ontología hermenéutica al aplicarlo indistintamente al ámbito lógico-cinético propio de las racionalidades científicas y al ámbito dianoético que sólo es propio de las virtudes intelectuales comunicativas excelentes. Con ello vendría J. Habermas a borrar de nuevo la diferencia ontológica, extendiendo la racionalidad intensiva a todas las acciones linguísticas. El consiguiente deterioro y confusión de los campos epistémicos entre sí resulta inevitable. Oscila, en efecto, entre el cientifismo difuso y la retórica relativista, pero eso ya nada tiene que ver con la ontología crítica que marca la diferencia hermenéutica entre los dos planos del espacio-tiempo del lenguaje del ser, que se dan a la vez en las articulaciones condicionales o causales: el de lo necesario activo-extático, intensivo, y el de lo contingente, dinámico y extenso. Los dos modos de darse el uno, el límite, el criterio o la diferencia.

s5 En rigor filosófico y filológico se debe adevertir que la clave de interpretación coherente y unitaria no sólo de los lógoi metafisicos sino del Corpus en su totalidad (tal y como se lo debemos esencialmente a la excelente labor de Andrónico de Rodas con los lógoi esotéricos), reside en la precisa diferencia ontológica entre kínesis y enérgeia: Kínesis en tanto que práxis atelés potencial o "acción inacabada", y Enérgeia kaì Entelécheia en tanto que práxis teleía o "acción acabada, comunicativa, reflexiva y transmisivam. En este orden cabe destacar, en cierto modo, entre los estudiosos de habla castellana, los invalorables trabajos del valenciano Fernando Cubells, cuyo atento conocimiento del texto de Aristóteles le lleva, no por casualidad, a subrayar la marca temporal que distingue la enérgeia (sincronía) de la kínesis (diacronía), correspondiendo al modo actual y potencial propio respectivamente de las potencias perfectas e imperfectas. Es cierto que F.Cubells no enlaza después este descubrimiento modal-temporal con la henología del espacio: intensivo o extenso que corresponde en Aristóteles, siguiendo a Platón, al estudio del uno-límite; pero si decimos que efectúa este descubrimiento no por casualidad es porque ya estaba F.Cubells - al hilo del problema de la reflexividad, que diría Gadamer — sobre su pista, cuando investigaba en profundidad el problema del "Eterno Retorno" mientras buceaba en los textos de los filósofos Presocráticos. Textos de los ontólogos del lenguaje donde Aristóteles mismo aprendió a trazar la Diferencia que le hizo poder remontar el materialismo de una realidad reducida a lo cinético-extenso y descubrir el ámbito transcendental de las acciones extáticas-límite. No quietas, pues la quietud es lo contrario del movimiento y le copertenece, sino inextensas por intensivas, ni motrices ni inmóviles, sino ausentes o presentes, ocultas o des-ocultas: las acciones indivisibles propias de las vidas de las almas en todos los seres animados y del conocimiento noemático espiritual en el caso del hom- 
Así lo enseñaba también Parménides en su poema didáctico: «Lo mismo dará por donde empiece... ${ }^{56}{ }^{2}$. Y por eso en el Proemio escogía las imágenes primero de las ruedas echando chispas de velocidad en su vórtice, y luego del círculo, la más continua de las figuras geométricas, la más indivisible o unitaria, aquella para cuyo trazado resulta indiferente el punto de partida. Tal es su perfecta díke o justicia: la de la equidistancia exacta de todas las partes al centro inextenso del que participan: el mismo uno primero, incondicionalmente indivisible, intensivo, que posibilita la unidad posterior del todo-extenso circular, estructurado por los radios referidos al centro; siendo este "todo" una unidad-indivisible, por un lado, el del uno, y por el otro, por el lado del «todo», también divisible y que está dividido, una unidad vista desde las "partes".

Por esto Aristóteles, también siguiendo fielmente a Heráclito, tanto en la filosofía del hén-sophón (uno-sabio) como en la lógica intensiva del alma cuyas acciones se multiplican sin dividirse -igual que llegan a ser sin generarse- y se incrementan cuanto más se dan ${ }^{57}$, habrá de precisar con sumo cuidado lo siguiente, enhebrándolo con el noeîn de Parménides: que el primer uno-indivisible, una

bre, a las que su ontología reconoce, en todos los casos, la debida primacía del límite-bien sobre el movimiento y la generación. Una profunda religiosidad racional: la teología inmanente y desvelada del pensar del sentido del ser; tal y como se da-oculta en el lenguaje que se abre a la noética de los primeros principios-leyes ontológicos. Tres escritos admirables se deben destacar, al respecto de la cuestión que nos ocupa, de entre la obra de este gran filósofo valenciano que fue Fernando Cubells: Los filosofos presocráticos. Estudios inéditos de Filosofia Antigua. (Empédocles. Origenes históricos de la ciencia ética). Facsímil de la primera edición (1956). Facultad de Teología San Vicente Ferrer, Series Valentina, II, Valencia, 1979; El Acto Enengetico en Aristóteles. Separata de la Revista Anales del Seminario de Valencia, n. ${ }^{\circ}$ 1, I Semestre 1961, pp. 2-110; y El Mito del eterno retorno $y$ algunas de sus derivaciones doctrinales en la filosofia griega. Separata de la revista Anales del Seminario de Valencia, Año V, II Semestre 1965, n. ${ }^{0} 10$, pp. 5-175.

56 "Me es igual por donde empiece, pues allí mismo regresaré otra vez de nuevo» (DK 28 B 5; Proclo, In Parm. I 708, 16). Nuestra trad. en El nacimiento..., op. cit., p. 187.

${ }^{57}$ Cfr. Aristóteles: Metaf. VIII-5, 10044b 21-30: «Puesto que algunas cosas existen y dejan de existir sin generación ni corrupción (...) y no todo tiene materia sino tan sólo las cosas sujetas a generación y a cambio recíproco. Pero las cosas que sin cambiar existen o dejan de existir no tiene materia»; y Metaf. IX-8, 1050 30-1050b 2: "Pero cuando las potencias tienen como resultado alguna otra cosa además del uso, su acto está en lo que se hace (por ejemplo la edificación en lo que se edifica y la acción de tejer en lo que se teje, y de modo semejante en las demás cosas, y, en general, el movimiento en lo que se mueve), pero cuando no tienen ninguna otra obra sino la acción, la acción está en el agente mismo (por ejemplo la visión en el que ve, la especulación en el que especula y la vida en el alma; por eso está en el alma la felicidad, pues es vida de una calidad especial». 
vez cumplidas las disposiciones de la justicia y armonía de que se trate, en cualquier sistema de orden, es el límite limitante simple y actual-modal propio de las acciones-diferencias que logran ser ellas mismas tan intensamente como para simplemente ser o plenamente ser o solamente ser firmemente esto, esta tal diferencia plenamente. Un modo de ser solamente tal que se da solamente en el lenguaje incomposible del noeîn pathetikón humano: el pensar simple receptivo de lo simple, de lo solamente afirmativo, de lo excelente ${ }^{58}$.

Un pensar indivisible siempre disponible o abierto para la acción-diferencia excelente porque no se compone con ella, sino que es y llega a ser ella y se actúa por ella, aunque sólo en cuanto a su modo de ser; $y$ así haciéndolo, por el mero experimentar de ese solamente pasar plenamente a ser, la re-conoce, y la atestigua, dice que sí que la hay: la re-afirma simplemente como ser, como bien, como virtus ontológica del pensar-lenguaje. Un pensar-lenguaje sin imágenes, extensión, ni memoria; cuya potencialidad extática deseante sólo puede ser actuada por las acciones-diferencias que son con su mismo modo de ser simple pero siendo activas: praxis o actos o acciones realizadas del modo excelente, intensivo y comunicativo que es propio de todo aquello que alcanza tal bien ontológico (el suyo, el de su diferencia-límite) y cuya marca característica es el placer de ser plenamente. El placer ontológico cuya experiencia engendra el deseo noético (el noûs orektikós) de volver a experimentar tal modo de plenitud: la del pensar-ser-excelente del bien-acción, la del despertar por la vigilia del bien, la de participar en el bien de la virtud y poder afirmar, sólo afirmar, solamente afirmar la afirmación sin contrario, propia del límite indivisible y activo -el limitante-, con una gratitud plena de placer. Un pensar-lenguaje siempre disponible y abierto a toda-cualquier diferencia excelente posible, para simplemente ser al afirmarla y alcanzarla por deseo y placer del bien, por deseo del ser-bien y de su patencia, de

${ }^{58}$ Cfr. Aristóteles: Metaf. IX-6-10. Véase asimismo H.-G.Gadamer: "La filosofía griega y el pensamiento moderno", en El inicio de la Sabiduria, op. cit., pp. 125-133. Y una mejor versión del mismo trabajo de Gadamer en "El significado actual de la filosofía griega", contenido en la colección Acotaciones hermenéuticas. Trad. Ana Agud y Rafael Agapito. Ed. Trotta, Madrid, 2002, pp. 125-142. Pero es sobre todo en el ya mencionado texto de 1992 "Palabra e imagen "Tan verdadero, tan siendo" ", que Gadamer dedica a Goethe, donde de la manera más explicita reconoce Gadamer que la Diferencia ontológica de Heidegger - puesta en juego por éste sobre todo a partir del libro de 1936 El Origen de la obra de arte - no es sino la enérgeia no cinética de Aristóteles, tan diversa del movimiento como «lo mismo" (tò autô) del ser-pensar infinitivos y sólo afirmativos del Poema de Parménides. Pues es Parménides quien está en el origen radical de la Diferencia y la Verdad ontológicas (cfr. op. cit, especialmente pp. 292-306). 
que lo haya y de que se den sus diferencias plenamente. Un pensar-lenguaje continuo que olvida inmediatamente y vuelve a ser sólo la posibilidad actuable abierta a todas las causas diferencias cuya plenitud virtualiza a fin de ser actualizado por ellas.

A tal experiencia racional extática y no cinética del pensar-pasión-virtud del ser-acción-virtud, llama Aristóteles, siguiendo a los presocráticos, experiencia del pensar: noeîn, que culmina en la acción-verdad enérgeia kaì alétheia, recibida y transmitida: kaì entelécheia. Pues para completar el ciclo del pensar abierto por la diferencia-bien del otro, en el caso de las pasiones-acciones virtuosas del alma noética, señala Aristóteles al otro también al final del proceso de la verdad, cuando dice, con una sencillez conmovedora, que la enérgeia-alétheia tiende a la entelécheia porque "el fin del maestro es ver al alumno enseñando» (Metaf. IX, 1050a 17-19). Ello de acuerdo con la lógica modal intensiva inagotable, que es siempre el modo diferencial de la temporalidad durativa inmanente o eterna que se da aquí y es re-flexiva a la vez que transitiva, en todos los casos, pero aún más intensivamente en el de las virtudes dianoéticas humanas en cuya philía o amistad dialogal funda Aristóteles la autopercepción que acompaña al percibirse, al saberse a sí mismo, del pensar (noeîn) propio del lógos del alma humana dialogal $^{59}$. Un saberse gracias al otro más próximo posible al uno-mismo. El más amado: el amigo y los amigos. Un saberse fundado en la virtud de la mistad y en el placer dianoético ${ }^{60}$.

Pero volvamos al Uno y Todo (hèn kaì pân) que nos conducía desde el universo de Gadamer a las ontologías noéticas o espirituales de Parménides, Heráclito y Aristóteles, orientadas a lo que también el maestro Platón había localizado en el Bien ontológico del Uno intensivo. Ahora ya es más fácil comprender que el segundo uno-indivisible, el del "uno-todo" extenso, sea compuesto o referencial: potencial y cinético, con tantas clases de movimiento como permitan las clases de contrariedad y composición que cada uno de esos sistemas «uno-todo» registre, según su propia medida armónica. Tal es el caso de los organismos, o el del Kósmos, o el de cualquier síntesis compuesta, entre ellas, claro está, las de los

59 Para el estudio de la verdad ontológico-práctica en Ética a Nicómaco, véase nuestra discusión con Pierre Aubenque en el escrito ya referido: «P. Aubenque: proximidad y distancia del Aristóteles dialéctico», op. cit., epígrafe IV: «La theoría aristotélica de la virtud», pp. 108 y ss.

${ }^{60}$ Para la teoría aristotélica de la virtud de la Amistad y su determinante papel en la constitución dialógica de la autoconciencia, recuérdese la ejemplar enseñanza de Ética a Nicómaco en el largo pasaje I-9, $1169 \mathrm{~b} 30-1170 \mathrm{~b} 15$. 
propios conceptos universales, los juicios, las definiciones, y, en una palabra, todas las síntesis de la imaginación: visuales, acústicas, etc. Su unidad es potencial, por un lado, porque aun siendo unidades tienen estructura extensa divisible, ya sea de extensión con materia física ya con materia abstracta o cantidad lógica. Se componen de «todo y partes» igual que toda síntesis cuantitativa o todo concepto compuesto; y es potencial, también su unidad, por otro lado, porque remite a su causa simple intensiva actual o causa-límite, como a la unidad inmaterial (inextensa) que es condición posibilitante sin la cual el conjunto no sería un todo, distinto de la suma de las partes.

Lo interesante y más difícil, sin embargo, está en comprender que tampoco hay el Uno primero sin el segundo Uno, pues no hay condicionante sin condicionado, ni límite-limitante sin la síntesis de limitado e ilimitado que exhiben, por ejemplo, además de los conceptos universales, los números. Y si la diferenciación entre los dos unos o, para decirlo con propiedad, la diferencia entre los dos modos de ser del uno ${ }^{61}$, concentra la discusión nuclear de Platón y Aristóteles, no es menos cierto que tal discusión se retrotrae también a cierta diferencia entre Heráclito y Parménides que parece volver a trazarse entre Gadamer y su maestro Heidegger. Tal distancia no es otra - como hemos visto - que la concernida por la esencial discusión sobre lo que Heidegger ha llamado en nuestros días " $L a$ Diferencia Ontológica", y afecta, en primer lugar, al problema de la diferencia y relación entre verdad y opinión (dóxa kai epistéme) en todas sus declinaciones: mito y ciencia, verdad y mentira, verdad y mito, verdad, mentira y arte, verdad $y$ moral, verdad y creencia, verdad e historia, verdad y bien..., verdad y falsedad, verdad y no-verdad, verdad y error, verdad y olvido, memoria..., o para decirlo en términos que también involucran netamente la discusión de Nietzsche con Platón: suprasensible y sensible ${ }^{62}$. Una diferencia con cuyo trazado entre las acciones, pala-

${ }^{61}$ Véase "Parménides entre Platón y Aristóteles. El conflicto de las razones de Occidente», en El nacimiento de la filosofia en Grecia. Viaje al inicio de Occidente, op. cit., pp. 239-367. Y de H.G. Gadamer: «Parménides y las dóxai brotôn, en El inicio de la filosofia occidental op. cit., pp. 103132, donde se trata la Diferencia Ontológica en el sentido modal-henológico que estamos defendiendo, puesta en relación explícita con Heidegger-Parménides: cfr, pp.133 y ss.

62 Insistimos en que el sentido de la diferencia ontologica que Gadamer y Heidegger retrazan siguiendo a Aristóteles, Parménides, Heráclito y Anaximandro, no se entiende sino que se malinterpreta gravemente si se dice "diferencia entre ser y ente" y se lee subrepticiamente "el Ser y los entes" de acuerdo con los prejuicios monológicos y monoteístas, que asignan el uno al ser y lo múltiple a los entes. Por el contrario se debe reparar, con cuidado, en que lo uno y lo múltiple se dicen en los dos ámbitos de la diferencia: en el de lo ser-arché (los principios ontológicos necesarios) y 
bras e imágenes de la verdad y la apariencia decimos que comienza la discusión que aún nos distingue desde el Nacimiento de la filosofia y el Nacimiento de Occidente.

Discusión que está pendiente para nosotros desde el reto lanzado al futuro por Heráclito y por Parménides: comprender y actuar no sólo lo uno-mismo diferencial del tò sophón y el tò autó sino el koinós Lógos de la pólis ciudadana de Heráclito; y la legitimidad referencial de los juicios verosímiles: de los Éndoxa de los saberes y las ciencias, según nos sigue reclamando Parménides ${ }^{63}$ cuando la diosa de la verdad dice las siguientes palabras:

en el de lo ente-dóxa (los fenómenos, las creencias contingentes). E incluso entre el Ser y el NoSer (que es justamente por donde la diferencia entre lo simple y lo relativo se traza). Por eso Heidegger comienza Ser y Tiempo remitiendo al problema de Platón en el Sofista, o sea: a la méthexis o participación entre lo suprasensible y lo sensible, que plantea el problema de su enlace; la cuestión de la causa; y la cuestión, por ende, de la verdad. Heidegger rememora-actualiza así la discusión del "parricidio platónico" contra Parménides - al admitir Platón el no-ser entre los primeros principios absolutos-y, en definitiva, vuelve a plantear la discusión del nihilismo, tal y como ya había hecho Aristóteles rechazando decididamente esta solución platónica. Se gana ya mucho camino si se entiende que el problema de la diferencia ontológica es el problema de la relación entre lo suprasensible y lo sensible, o sea: la cuestión de la méthexis, porque es el problema del enlace de la diferencia, que afecta a mostrar cómo los eíde pueden ser causa del ser, del conocer, y del devenir, de los entes sensibles. Por eso, a partir de este planteamiento platónico que Aristóteles habrá de transformar invirtiendo el sentido del tiempo psicológico: del concepto a la acción; el problema de la méthexis volverá a encontrar su cauce en la cuestión de la causa-esencia ontológica como problema de la verdad práctica. $\mathrm{O}$, dicho en otras palabras y en resumen: podrá replantearse hermenéuticamente como verdad ontológica-práctica, que articula el modo de ser-acción de la verdad. Este sí es el enfoque diferencial de la diferencia ontológica.

${ }^{63}$ Dice Gadamer al final de su excelente estudio sobre el Poema de Parménides, contenido en el volumen El inicio de la Filosofia occidental: "Creo que nuestra lectura del Poema de Parménides demuestra muy bien que en este tema Heidegger tenía razón: la diferencia ontológica existe, se da y no es hecha. En efecto en el Poema se oscila entre el ente en su totalidad y el ser. La diferencia ontológica opera aquí ya en cierto sentido. Ésta es una de las razones del profundo respeto que Heidegger, como ya en otro tiempo Platón, sentía hacia Parménides (...). Heidegger —ya he aludido a ello- esperaba e intentaba demostrar que Parménides había intuido esta dimensión, a saber: que esta diferencia se da y no es hecha (...). En el fondo se encontraba aquél gran problema: el milagro que es el diferenciarse (...). Heidegger trató de encontrar todo esto en la filosofía eleática y también en Heráclito, para poder afirmar, siguiendo excesivamente a Nietzsche, que los primeros filósofos de la edad clásica de Grecia estaban más allá de la metafísica, y que el gran drama del pensamiento occidental, la caída en el abismo de la metafísica, no existía en la filosofia presocrática, más tarde ha visto que Occidente estaba ya preparándose en aquella época (...). Quiero concluir con alguna observación más sobre Heidegger. Creo que él ha puesto a Hegel al final de la historia de la metafisica porque su síntesis es, en cierto sentido, insuperable. La ruina del nivel conceptual 
«iBienvenido! Que no es un mal destino el que te envió por este camino — ciertamente está fuera del pisar de los hombressino ley y justicia (allà thémis te dike te). Es necesario que te enteres de todo: tanto del corazón sin temblor de la Verdad bien redonda como de los pareceres de los mortales (brotôn doxas), en los que no hay [verdadera credibilidad (pistis alethés). Pero, de todos modos, también esto aprenderás: cómo lo que aparece [(tà dokoûnta) créblemente tenía que ser (chrên dokimos eînai) pasando totalmente a través [de todo" ${ }^{64}$.

\section{Hermenéutica segunda: El origen espiritual del lenguaje y la historia}

\section{II.1. Problemas filosóficos a partir de Nietzsche. Nietzsche, Heidegger y Gada- mer con los presocráticos.}

Como es bien sabido, Gadamer se doctoró en filología clásica con una tesis sobre el tratamiento del "Placer» (hedone) en Aristóteles - tras quedar para siempre impresionado y según sus propias declaraciones bien-humoradas «abrumado" por la luminosa experiencia del pensar que actuaba en la escena de las aulas de Friburgo y Marburgo el inusitado magisterio del filósofo Martin Heidegger-

alcanzado por la filosofía del siglo XIX tiene lugar con el pensador más genial del siglo, Nietzsche, que sin embargo, era también un aficionado que no sabía mucho acerca de la filosofía moderna y ni siquiera había leído a Kant (...) En cualquier caso podemos ver cómo Heidegger es un pensador verdaderamente radical cuando afirma que la metafísica se ha transformado, pasando de ser horizonte común de la cultura occidental a ser una nueva metafísica que él ha llamado "olvido del ser" y ha descrito como predominio de la técnica en todos los campos de la cultura humana, no sólo europea sino también mundial. Heidegger tenía una gran capacidad de abstraer, formar conceptos, encontrar expresiones nuevas, aun cuando todo esto no sea siempre fácil de entender. $\mathrm{Ha}$ encontrado muchas cosas que nos han abierto nuevas posibilidades para pensar y para hacer hablar a los textos que la filosofía y el arte nos han transmitido. Es como si con él hubiese comenzado una nueva atmósfera. Ciertamente no es fácil moverse en esta atmósfera y seguir el camino que él ha abierto; por eso me gusta decir que así como Platón no era un platónico, tampoco Heidegger tiene ninguna responsabilidad de que existan los heideggerianos». Op. cit., pp. 133-135.

${ }^{64}$ Nuestra traducción del Poema de Parménides en El nacimiento de la Filosofia en Grecia..., op. cit., pp. 184-185. 
precisamente sobre la hermenéutica de los textos de Aristóteles ${ }^{65}$. Era cuando en la Facultad de Filosofía de Marburgo, de marcado corte neokantiano (y en el fondo hegeliano), presidida por figuras como las de Paul Natorp o Nicolai Hartamnn, también maestro de Gadamer, parecía volver a cobrar vida, a través de las lecciones de Martin Heidegger, el pensamiento de un nuevo Aristóteles. Un Aristóteles griego desconocido y sorprendente ${ }^{66}$ que, según ha declarado Gada-

65 Véase de H.-G. Gadamer: Mis años de aprendizaje, (1975). Trad. de Rafael Fernández de Maruri. Barcelona, Herder, 1996, pp. 248-253 y ss. Véase asimismo J.Grondin: H.-G.Gadamer. Una Biografia (1999). Trad. Ángela Ackerman, Roberto Bernet y Eva Martín-Mora. Ed. Herder, Barcelona, 2000, pp. 103-177; y H-G. Gadamer: Heideggers Wege (1990). Trad. Inglesa de John W. Stanley: Heidegger's ways, State Univers. Of New York Press, 1994, caps. 3, 6, 12, pp. 29-45; 61-69; 139-152. Bajo el rótulo "Heidegger y los griegos" dio Gadamer una conferencia en Padua el 9 de enero de 1979, donde contrastaba el modo de relacionarse Heidegger con la helenidad y el que establecieran antes muchos otros pensadores alemanes de Hegel a Cassirer y Hartmann. Decía así Gadamer: "Con Heidegger se introduce, sin embargo, algo enteramente nuevo: una nueva proximidad y un modo renovado de cuestionamiento crítico del comienzo griego, que le acompañó constantemente, desde sus primeros pasos independientes hasta los últimos años. El lector de Sein und Zeit puede darse cuenta sin dificultad de los dos aspectos: tanto de la cercanía como de la distancia. Pero hace falta haber asistido a las clases de Heidegger, durante estos primeros años de Marburgo, para poder evaluar la amplitud con que Aristóteles estaba presente en el pensamiento del Heidegger de aquél período", Heideggers Wege. Nuestra trad. Verifiche, 8, 1983, p. 7. Con el título Gadamer et les Grecs han reunido Jean-Calude Gens, Pavlos Kontos y Pierre Rodrigo los artículos-capítulos que configuran un volumen reseñable: ed. J.Vrin, París, 2004. Véase de entre ellos especialmente André Laks: "Gadamer et les Présocratiques", op. cit., pp. 13-29 y Francesco Gregorio: «Portrait d'une lecture: Gadamer dans Aristote», pp. 71-87.

66 Mucho se ha insistido, como siempre en el anecdotario - bastante útil- de la filosofía, en la relación de Heidegger con el libro de Brentano sobre los plurales sentidos del ser en Aristóteles, pero no puede olvidarse aquí que contamos con la edición monumental de la Academia de Berlín sólo desde 1831-1870, arco temporal en que fue publicándose la edición canónica del Corpus aristotelicum debida a E. Bekker, quien presenta las Lecciones de Aristóteles haciéndose cargo de la particular transmisión histórica y filológica de los textos. Cfr. E. Bekker: Aristóteles Opera edidit Academia Regia Borussica. Se trata de los lógoi hekroaménoi (discursos escritos para ser leídos, oídos y discutidos oralmente). Es decir: los lógoi esotéricos o Las Lecciones de Escuela de Aristóteles, no publicadas ni escritas para un público general. Textos que Andrónico de Rodas, Escolarca del Liceo en el siglo I a.C. reuniera en la primera edición del Corpus, a expensas de no incluir los escritos sí publicados, y al parecer bastante difundidos, de Aristóteles: Los exotéricos, todos los cuales se han perdido para nosotros, aunque los conocemos por una abundante tradición indirecta, entre cuyos testimonios destaca principalmente el de Cicerón, contemporáneo de Andrónico. Así pues sólo el Corpus de las Lecciones o lógoi hekroaménoi, ha llegado hasta nosotros gracias a una transmisión ininterrumpida que atraviesa las versiones de los comentaristas alejandrinos, medioplatónicos y neoplatónicos griegos, traducidas después a las lenguas siríacas, árabes, latinas y romances, hasta dar lugar a esta misma colección: la soberbia edición de E. Bekker, que junto con un impresio- 
mer en numerosas ocasiones, ha marcado su pensamiento de modo indeleble. Dice Gadamer lo siguiente:

Es verdad que el hegelismo que subyacía a las interpretaciones neokantianas de Platón ofrecidas por Cohen, Natorp y sus seguidores (Cassirer, Hartmann, Hönigswald, Stenzel) se mantenía en un plano secreto e inconfesado. Pero para la particular conciencia de esta generación de estudiosos, era exclusivamente Platón, y para nada Aristóteles, quien venía al encuentro de sus intereses crítico-idealistas. (...) A la luz de la interpretación idealistaneokantiana de Platón, la crítica a Platón por parte de Aristóteles no podía aparecer sino como un absurdo malentendido. Situación que ha contribuido no poco al desconocimiento de la unidad de la influencia platónico-aristotélica impidiendo a nuestro propio pensamiento filosófico la plena recepción de la heredad griega. Contraposiciones banales e ingenuas, tales como "Platón el idealista" y "Aristóteles el realista", habían llegado a convertirse en lugares comunes. Pero tales tópicos sirven apenas para documentar la falta de cuidado en que había caído la conciencia idealista en general. Igual de desfavorable para adquirir una correcta valoración del significado y papel fundamental que le corresponde al pensamiento griego en relación a la filosofía moderna, resultaba también el esquema, inspirado en Hegel, según el cual el pensamiento griego no habría llegado todavía a un grado de madurez suficiente como para alcanzar a entender el absoluto como espíritu, vida o autoconciencia. La época en la que yo mismo - estimulado por la toma de distancia crítica de Nicolai Hartmann respecto del idealismo neokantiano- me atrevía a penetrar en el pensamiento aristotélico (...) se estaba todavía lejísimos de comprender la unidad de la filosofía del lógos, que se había iniciado con el interrogar socrático y desapareció rápidamente después de Aristóteles, ya en el período postaristotélico, condicionando así de manera persistente la entera conceptualización del pensamiento occidental. Cómo resultó de decisivo para mí en aquel tiempo el encuentro con Heidegger (...).

nante equipo de filólogos e historiadores fue publicando los Escritos de Escuela a lo largo prácticamente de todo el siglo XIX, haciéndose especialmente cargo de la diversa hermenéutica puesta en juego por las distintas lenguas y culturas receptoras-transmisoras, normalmente niveladas por la tendencia general del neoplatonismo que lee a Aristóteles desde Platón. Véase Para leer la Metaftsica de Aristóteles en el siglo XXI, op. cit., pp. 19-38. 
Heidegger había atravesado la tradición católica del aristotelismo tanto como el neokantismo y la minuciosa técnica husserliana del concepto, adquiriendo el temple de resistencia y la virtud intuitiva que resultan indispensables para quien quiera filosofar con Aristóteles. De tal suerte que aquí se encontraba uno en presencia de un abogado de Aristóteles que superaba con mucho, por inmediatez y frescura fenomenológica, todos los aspectos tradicionalistas del aristotelismo, del tomismo y hasta del hegelismo. Todavía hoy se recibe con dificultad y resistencia el hacerse cargo de la amplitud de este fenómeno que, sin embargo, fue reconocido y constituyó una realidad para la vida académica de entonces, viniendo a determinar, entre otros, también mi propio itinerario filosófico. Cuando en 1931 se publicaba mi primer libro, La ética dialéctica de Platón, ya resultaba para mí evidente, al menos en el campo de la filosofía práctica, la convergencia de las intenciones del pensamiento platónico con las distinciones conceptuales aristotélicas (...) Los estímulos filosóficos que, por mi parte, había recibido de Heidegger no podían sino introducirme cada vez más en la dialéctica, ya fuera platónica, ya hegeliana. Durante décadas he dedicado mi enseñanza a la elaboración y la verificación de lo que he llamado «la unidad de la influencia platónico-aristotélica». Pero en la base de todo esto no estaba sino el constante reto que para mí representaba el camino personal abierto por Heidegger en el pensamiento, y en particular su interpretación de Platón como paso decisivo en la dirección del olvido del ser que caracteriza el pensamiento metafísico. Cómo haya yo acertado o no a responder teoréticamente a tal reto se ha de calibrar siguiendo la elaboración de mi proyecto de una hermenéutica filosófica consignado en la obra Verdad y método ${ }^{67}$.

Pero no vayamos tan deprisa y empecemos por Nietzsche antes de llagar a Heidegger y su extraordinaria recepción del Aristóteles griego continuador del êthos-lógos de su maestro Platón y de la ontología del bien y de las diferencias. No por eso menos crítico con Platón en cuanto al asunto crucial de la verdad ontológica y de la diferencia ontológica. Verdad y Diferencia de la que Platón se habría apartado — según Heidegger-y se habría ido olvidando, a partir del des-

${ }^{67}$ Nuestra trad. H.-G. Gadamer: Die Idee des Guten zwischen Plato und Aristóteles, Sitzungsberichte der Heidelberg Akademie der Wissenschaften, Phil.-Hist. Klasse, C. Winter, Heidelberg, 1978. Gesammelte Werke 7, Griechische Philosophie III. Ed. Mohr Siebeck, 1991/1999, pp. 128227. 
vío nihilista que emprendiera tras el parricidio de Parménides - como llamaba Aristóteles al hecho de que Platón hubiera introducido el No-Ser en el plano de los primeros principios dualistas, desde las soluciones del Sofista-. A partir de ese momento - también según Heidegger - se abría la vía errada (y sin salida) hacia el olvido del ser como hilo conductor y camino progresivo de La Historia triunfante de la metafísica occidental. La historia de la salvación, la emancipación y la libertad, que creyendo huir de la muerte se habría ido precipitando cada vez más en la nada. La historia nihilista de la metafísica de Occidente de la cual no cabría ahora ni continuación, ni repetición, ni superación, sino otra rememoración (Andenken) de lo mismo desde el comienzo, por la vía de su diferencia tapada. Por el otro lado. Por la vía del otro tiempo-espacio y el otro lenguaje: el de la filosofía y el arte, que había abierto Nietzsche. Porque escarbando entre las grietas del error, bebiendo el cieno de lo falso, escudriñando en las potencias de lo falso y el olvido, buscando en lo desechado y excluido, silenciado, roto y fragmentado, Nietzsche hacía dar con una Grecia desconocida y asombrosa que estaba desde antes ya ahí, en el ser-ahí inicial de esa misma herida. En el límite de la diferencia que es el ser-ahí para nosotros, para nuestra memoria de lo porvenir, ahora, si es que algún porvenir fuera posible.

\section{II.1.a. Nietzsche y los presocráticos}

No es nada improbable que F. Nietzsche, como filólogo clásico, particularmente interesado, además, en las grandes colecciones de las tradiciones y compilaciones anónimas griegas (la que atribuimos a Homero, la de los escritos médicos hipocráticos, la del Corpus atomista y la de los escritos escépticos que desembocan en Sexto Empírico, por ejemplo), fuera conociendo y siguiendo, a lo largo de gran parte de su vida intelectual, la aparición editorial de los volúmenes del Corpus de Aristóteles publicados entre 1831 y 1870 por la Academia de Berlín ${ }^{68}$. Parece difícil suponer, al contrario, que Nietzsche pudiera ignorar un acontecimiento coetáneo, histórico y filológico, de tal magnitud, precisamente en el campo de su competencia y en materia de estudios helenistas. Pues, en efecto, nunca antes el mundo académico había dispuesto de un material crítico semejante a esta rigurosa reconstrucción de los textos esotéricos de Aristóteles y de sus

${ }^{68}$ Véase supra, nota 62. 
distintas recepciones y versiones: las griegas, siríacas, árabes, judías, latinas, escolásticas y modernas, hasta llegar a las ediciones y traducciones del Corpus que discutía el equipo de Bekker a la hora de razonar sus propias opciones hermenéuticas en cuanto a la fijación de los textos. Tal era la urdimbre explícita de la edición de los Tratados de Escuela del Estagirita, escrupulosamente preparada por un prestigioso equipo de filólogos, historiadores, helenistas y reputados estudiosos, coordinado por E. Bekker para la Academia de Berlín.

Es cierto que la impronta general de esta monumental obra no tardaría en dar lugar a un fenómeno de acendrado criticismo aristotélico, sin parangón posible desde el renacimiento italiano de los clásicos. A lo largo del último siglo, el siglo $\mathrm{XX}$, no han cesado de discutir y revisar punto por punto las versiones, las interpretaciones, los contextos y los problemas que han suscitado estos textos de Aristóteles destinados a transformar radicalmente nuestra visión de la filosofía del propio Aristóteles, para empezar. Y, como no podía ser menos en el caso de una filosofía que, como la de Aristóteles, hace del diálogo y la discusión su única metodología crítica, también la de las restantes posiciones de la filosofía griega en su conjunto. A partir del Aristóteles de Werner Jaeger de 1923, y por mucho que esta obra evolucionista demasiado pegada a su época haya terminado por ser hoy más rechazada que admitida en cuanto a sus propuestas concretas, se ha ido imponiendo a la crítica la expresión con que Giovanni Reale celebra y consagra el «Renacimiento actual de Aristóteles». El renacimiento de un nuevo Aristóteles, un Aristóteles griego desconocido: el más antiguo, que tenemos que aprender a leer no desde las interpretaciones de las culturas que lo transforman, mientras lo reciben e integran, sino desde antes. Desde los problemas a los que él remite explícitamente porque él considera necesario recibirlos conectando así con su propia tradición. Es decir: desde las preguntas precisas a las que Aristóteles se propone responder con su filosofía. Así nos ha enseñado a leer Gadamer. Pero justamente en este contexto es donde la voz del profesor Nietzsche clama desde su máscara más profunda: la que ríe, llora y salta, medio asfixiándose y protegiéndose por entre la montaña de nubes de polvo que han producido los archivos de la universidad sacados a la luz. Pues se ha de decir a voces, todavía, que si la Academia aún se resiste como gato panza arriba a recibir al nuevo-antiguo Aristóteles griego es porque éste la obliga a volverse del revés, poniendo en solfa las raíces mismas de su propio lenguaje oficial y de su aparato conceptual en general (el construido durante siglos de sedimentación de las similares precomprensiones vehiculadas por las interpretaciones bíblicas y secularizadas de Aristóteles). Nietzsche se dio cuenta en el acto. 
Nietzsche estaba preparado - vaya si lo estaba - para pensar las piezas inconexas que iban rescatando los filólogos y para aventurarse él mismo, sólo si fuera necesario, una vez abierta la puerta del tiempo, hasta el origen de nuestro lenguaje. Él mismo se había situado ya - sobre todo a partir de la ruptura con Wagner- en la intempestividad de un suelo post-cristiano como superficie de inscripción de los fenómenos lingüísticos y artísticos. ¿ No andaba ya por entonces rastreando los orígenes de la tragedia ática en el culto religioso-político al dios Dionisos? ¿No andaba iniciandose en los misterios délficos de Eleusis, junto a la pólis de Atenas? Además sabía cómo orientarse. Sabía que entre todas las expediciones posibles por entre las huellas de los siglos dejadas en la masa del Corpus aristotelicum, había un conducto que atravesaba los estratos circulares del laberinto: el hilo que proporcionaba la implacable crítica de Aristóteles a la modernidad de Sócrates-Platón, sobre todo vista desde la perspectiva del pólemos de Aristóteles contra Espeusipo, el matemático pitagorizante, orientalizante.

Quizá Nietzsche no consiguiera salir del laberinto por falta de aire. Quizá no le diera tiempo a subir y olvidar tan deprisa como para poder volver a darle la palabra a Platón, en el camino de vuelta hacia la superficie, cuando le vio depositando guirnaldas de mirto en la tumba de Heráclito. Eso parece pensar Gadamer. O quizá Nietzsche, el gran filósofo Nietzsche, no estuviera preparado para la ironía de Platón, el literato. Cabe, sin embargo, que el mismo Platón como "personaje literario" y las ficciones de su conversación sobre la verdad del arte, terminaran por interesarle más que los personajes "reales" de fuera del laberinto, en su propia época. Pero mientras tanto parece habernos convencido a muchos de entrar, y lo cierto es que Nietzsche ya ha estado demasiado tiempo sólo al otro lado del espejo. Queda, por último, lo más sencillo: acompañarle en su recorrido por los nuevos y diversos caminos de las antiguas sendas (esto es lo que han hecho Martin Heidegger y Hans-Georg Gadamer, pero también Giorgio Colli y María Zambrano, Gilles Deleuze y Margeritte Yourcenar, y Gianni Vattimo, y Derrida, de otra manera, y Eugenio Trías de otra diferente... y yo misma..., por no dejar de mencionar ahora a algunos entre los muchos hijos e hijas de Nietzsche ${ }^{69}$ ). Cabe intentar comprender, para empezar, a dónde le haya llevado Aristóteles.

${ }^{69}$ Véase el libro de Gianni Vattimo: Diálogo con Nietzsche, y mi Prólogo «Los hijos de Nietzsche», ya referido. Sobre la interpretación gadameriana de la mímesis platónica y aristotélica, cfr. Robert. J. Dostal: «La Redécouverte gadamérienne de la Mimèsis et de l'Anamnèsis, en Gadamer et les Gress, op. cit., pp.33-52. 
Pues, en efecto, sea de todo esto lo que fuera, lo cierto es que la crítica genealógica de Nietzsche a la tradición de la metafísica cristiano-platónica, extendiéndose hasta Kant y Hegel, desenvuelve con el método genealógico hacia atrás exactamente la misma crítica que Aristóteles destina a probar la imposibilidad de las Ideas-Seres Universales platónicas. Las Ideas derivadas del Uno Genérico, máximo universal, tomado como Ser Supremo. Así re-escribe la insignificancia del origen nietzscheana, la difícilmente contestable recusación del infinitismo metodologico que es desenmascarada por Aristóteles como procedimiento potencial y logicista característico de la dialéctica inconclusa. Racionalidad esta sólo potencial, y siempre tentativa, pero incapaz de llegar a la verdad. Lo cual podría conseguir la dialéctica sólo saltando de los conceptos a las acciones-límite con causalidad final-modal. También para Aristóteles -curiosamente igual que para Nietzsche - los universales fundamentos de la Metafísica platónica no son sino conceptos hipostasiados cuya única fuerza (tremenda) proviene de la costumbre repetitiva del mito y su característica reduplicación homogénea narrativa: la que absorbe la diferencia en el concepto. Entes duplicados y declarados En-sí o Primeras causas suprasensibles siendo mímesis de los entes sensibles. Inversión atroz para la vida despreciada por sus propias sombras-Ideas, erigidas en mayúscula pirámide mortuoria. Pero basta con someter los universales-seres al análisis racional de las causas para que se disuelvan en sus elementos, porque ningún universal es entidad-diferencia indivisible. Eso objeta incansablemente Aristóteles. Y porque la asimilación causa-origen y causa-predicación, con que Platón prosigue a Sócrates en busca de la unidad de la virtud y la unidad del concepto, no consigue, por más que se arrastre sin aliento, llevar a cabo una crítica suficiente de la imaginación-extensión y la memoria imaginativa. Porque no es capaz de frenarse en su baja pasión intelectual: la tendencia nihilista hacia el universal indiferente supremo. La nada confundida con la muerte. La nada de la diferencia y el todo de la extensión del sujeto (bypokeimenon) como substrato o fundamento absoluto. El Uno, como Género Supremo tenido, en la inversión más vacía respecto de la vida y los lenguajes de la vida, como Ser supremo y como Arché. La nada ocupando el lugar del ser. Tal es la inversión de los valores de lo que Nietzsche y Aristóteles llaman La Metafisica platónica, continuada, a partir de la platonización del cristianismo, como núcleo estable y continuo de la historia decadente occidental. Por eso la repulsa de Nietzsche respecto de la violencia de tal progresivo atentado contra los lenguajes de la vida y del ser, se deja compendiar en una sola consigna y una sola imagen: «invertir el platonismon. 
Invertir el platonismo de Platón que no consigue, de acuerdo con Aristóteles, sobre todo, invertir el tiempo cinético siempre más allá de todo límite, tenido por negativo. Aristóteles se pliega en la sabiduría de los límites de Delfos y protesta: hay que pararse en el límite, re-conocer el límite de las síntesis conceptuales y proseguir la búsqueda de la unidad de las síntesis en otro plano temporal transcendental: el de las condiciones posibilitantes simples, que en el caso del Macedonio no ha de buscarse por la vía genética, sino por la vía sincrónicocondicional del ser del tiempo, hasta dar con el bien modal práctico al que se orientan las acciones de las almas de los compuestos vivos. Para ser ellos mismos plenamente lo que ya eran -se orientan al bien ontológico de su propia diferencia - como condición inmaterial y eternidad inmanente de su estructura material. Pero entonces hay que invertir el sentido del tiempo cinético, y comprender la profunda sencillez que se alberga en la fórmula metodológica de Aristóteles, desgastada y manida hasta la opacidad: que «lo último para nosotros es lo primero por-sí» o causal ${ }^{70}$. Y ello porque para ser fiel al Platón del bien ontológico - de acuerdo con Aristóteles- hay que mantener que sólo el bien inmanente es un fin-límite indivisible para cada una de las vidas soberanas: las que tienen en ellas mismas su propio último principio, siendo su esencia su propia causa. Por eso en todas las entidades que son katà physin-dice Aristóteleshay, por naturaleza, algo divino ${ }^{71}$.

No es cuestión ahora sólo de rehabilitar la hermosa hondura érica de la racional teleonomía de Aristóteles, secularmente mal entendida en términos cinéticos o instrumentales, cuando no orientados al Dios único, creador y todopoderoso de las religiones bíblicas (como si el finalismo pudiera ser para los seres vivos, en la filosofía de Aristóteles, algo distinto de ser y hacerse plenamente actual su propia esencia-causa). Pero si, en efecto, la teleología de Aristóteles no puede ser sin más comprendida, ello se debe precisamente a cómo falta siempre al receptor el punto de vista crítico del hombre con el ser-hombre mismo, y esto es lo único que el Aristóteles griego reclama desde sus lecciones de continuo. Situarse en emplazamiento ontológico-crítico que se hace cargo del punto de vista propio de lo humano en tanto que mortal y consciente de la muerte. El emplazamiento que se exige siquiera para poder establecerse en la perspectiva que le es propia

${ }^{70}$ Cfr. Metaf. a, 2, 994 a, 11-994b 15; a, 2, 994b 13-16 y ss., 20-31; $Z, 9,1034$ a 8; $\Theta, 8$, $1050 \mathrm{~b} 2$ ss.; $M, 8,1084 \mathrm{~b} 14-16,1084 \mathrm{~b} 18-24$.

${ }^{71}$ Cfr. De Partibus Animalium, I-5, 644b 23-29. 
a Aristóteles y él demanda: que se invierta el sentido del tiempo genético-lineal del movimiento y las producciones tecnológicas, a la hora de comprender el ámbito de la vida. $Y$ ipor qué? Porque éste es el reino del alma y del eterno retorno de la mismidad-diferencia, tanto en la physis como en la pólis, pero sobre todo en el ámbito donde se da la ontología de la creatividad que es propia de la racionalidad espiritual del amor $^{72}$.

Lo que sí importa, en efecto, ahora en relación a Nietzsche, es advertir que ya para Aristóteles, en discusión con la pitagorización progresiva de la Academia de Platón, se trata explícitamente de invertir el tiempo cinético y el predicativo: el de las génesis lógicas por derivación y división a partir de la cantidad lógica de los predicados universales. Esto si se quiere acceder al ámbito de la vida-alma y a los lenguajes de la vida, donde más reina la lógica de la intensión del límite cuanto mayor es la soberanía del lenguaje y la re-flexividad espontánea ${ }^{73}$.

El pensar del Eterno Retorno nietzscheano indica, así comprendido, una de las primeras caras de su inusitada riqueza: la de acreditarse como méthodos o camino de la verdad viva, ya desde el Aristóteles griego leído desde Aristóteles. Quien recuerda, una y otra vez, que la ley ontológica exige respetar la primacía de la acción (prâxis-enérgeia) sobre lo potencial y el movimiento (dynamis, kinesis); lo cual equivale a decir que el filósofo macedonio sienta, de-limitando a Platón, la siguiente experiencia del pensar: que sólo desde el punto de vista crítico respecto de las génesis diacrónicas se abre el ámbito sincrónico de los límites-fines y su articulación. Porque las primeras causas y primeros principios ontológicos son -lo cual es precisamente atestiguado por nuestro único modo posible de acceder a ellos- «lo primero por sí (kath' hautó) que es lo último para nosotros» ${ }^{74}$.

${ }^{72}$ Cfr. Para leer la Metafisica de Aristóteles en el siglo XXI, op. cit., pp. 340-395.

${ }^{73}$ Cfr, ibíd., pp. 406-466.

${ }^{74}$ Cfr. ibíd., pp. 56-59. Aristóteles: Físicos, II- 9, 200a 8-14; III, 2-3 202a 25 ss., 6, 207a 815 y 207a 31-32; V-1, 224b 6-18 y 236b-237a; VI, 5, 236 a 4-16. Metafisicos, $\Lambda$-10, 1057b 7-12; De anima, I, 404 a 223 y ss. y 406 a 3-20. De partibus animal. Libro I. Véase de S. Mansión: «Plus conu en soi, plus conu pour nous: Une distintion epistémologique importan chez Aristotem. Rev. Pensamiento, n. ${ }^{\circ}$ 138-139, Madrid, 1979, pp. 145-161. Véase un amplio comentario y documentación sobre la «Rigurosa primacía de la causalidad formal-final en el orden de los Principios" y "La crítica aristotélica de las metafísicas del origen» en Para leer la Metafisica..., op. cit., pp. 348394. Dice Aristóteles: "Lo posterior en cuanto a la generación es anterior en cuanto a la entidad (ousia) (Metaf. M-2,1077a 27-28). "Más allá del fin no hay nada, pues el fin es lo último en todo, y contiene todo lo demás; por eso no hay nada más allá del fin y lo perfecto no necesita de nada». (Metaf. I-4, 1055a 14-15). «Y el fin es la acción (télos d' he enérgeia) y por causa de ésta se da la potencia (dynamis)» (Metaf. $\Theta-8,1050$ a 9-10). 
A partir de ese punto, la indagación de la reescritura hermenéutica del Nietzsche lector de Aristóteles habría de afectar a las problemáticas consabidas, y sólo apuntaremos muy brevemente algunas vías, que son éstas: (A) la vía del "Dios ha muerto" de todos los monoteísmos y todos los fundamentalismos, en base al politeísmo racional de Aristóteles, para quien está lo sagrado de los elementos (tierra, fuego, aire y agua), lo divino plural de todas las comunidades vivas de seres naturales y políticos; y lo divino de la nóesis humana que se manifiesta en las virtudes dianoéticas por participar entonces el alma noética o alma espiritual humana del límite del Nốs divino: el Espíritu del Dios absolutamente desconocido, al otro lado del límite. Lo sagrado, lo divino y el Dios. Tríada que, sin duda ha llegado también al Heidegger, lector de Aristóteles ${ }^{75}$.

Y si enlazamos ahora tanto la problemática del deseo vertida en (B) la "Voluntad de potencia» y el "Übermensh», como apelación a un "transhombre» de buen temperamento (ya no tan humano, demasiado humano, como para repetir una y otra vez la prepotente enfermedad de la Historia, en base a repetir la venganza contra la vida y el resentimiento contra ella que provienen de no admitir el límite de la muerte...) con la constante apelación del Estagirita a la primacía del límite y la virtud de la phrónesis o prudencia racional prácti$\mathrm{ca}$, podremos advertir que tales motivos son acordes con el principio metodológico de la primacía de la acción-límite sobre lo potencial infinito. Entonces no será difícil reconocer tampoco los mismos motivos contranihilistas en ambos filósofos, Aristóteles y Nietzsche; y registrar, por tanto, un precedente asombroso del Nietzsche deconstructor del humanismo cristiano-socrático en la crítica de Aristóteles al exceso del humanismo antropocéntrico pitagórico, platónico, protagórico y socrático con que la Academia habría querido encerrar a la Filosofía, reduciéndola a la moral y la esfera del hombre contra la physis. Un concepto de hombre dualista mitológicamente interesado en la salvación ultraterrena de su alma individual enteramente contraria a la aceptación de la muerte fisica. En efecto, por eso había apelado ya Aristóteles, contra la Dialéctica académica, al precedente de la gran ontología inicial de los filósofos pre-socráticos, los fisicos, para mostrar que si la Dialéctica seguía apartándose de la Filosofía inicial de los límites - del ser de la naturaleza y el lenguaje-, lo haría por la senda errática de una mera dialéctica potencial o de la

${ }^{75}$ Véase mi tarabajo ya referido «El criticismo aristotélico en siglo XX: Hacia un cambio radical de paradigma". 
fuerza o del poder. Es decir: por la vía del no-ser que ya presintiera el sabio Parménides como destino errático del Lógos ${ }^{76}$.

Pues, en relación ahora a las cuestiones del (C) Eterno Retorno y el Nihilismo, habría que considerar que si el hombre no asumiera la inevitable condición mortal de su destinación como hombre, ni fuera consciente de las implicaciones y proyecciones que, por ser mortal, no puede evitar tampoco a la hora de conocer, tendería a tomar el lógos del lenguaje como un super-instrumento de poder facultativo sin igual, pero indiferente al bien de la physis kaì poblis ${ }^{77}$. Tendería a anteponerse al lenguaje, a ponerse «antes» del lenguaje, en su imaginación, como si pudiera producirlo o utilizarlo, invirtiendo entonces el sentido del tiempo eterno en tiempo contingente-mortal, según el «antes y el después», para declarar contingente, efímero y vaciado de sentido a todo lo sensible, con la excepción de sí mismo y de sus semejantes, puestos a salvo. El hombre se habría convertido imaginariamente en un dios mitológico, un dios del poder, un dios del origen. Pero no otro nihilismo, violento y arbitrario, habían sometido ya a crítica radical los primeros filósofos contra-mitológicos y contra-dogmáticos, los presocráticos, apoyando en tal crítica el nacimiento de la filosofía. Lo cual equiva-

${ }^{76}$ Dice Aristóteles: «Los dialécticos y los sofistas revisten la misma figura que el filósofo, pues la Sofística es sabiduría —aunque sólo aparente-, y los dialécticos disputan acerca de todas las cosas, y a todos es común el ente; pero evidentemente disputan acerca de todas estas cosas porque son propias de la Filosofía (...) pero ésta difiere de una por el modo de la potencia (dynámeos), y de otra, por la previa elección de la vida; y la Dialéctica es tentativa (peirastike) de aquellas cosas de las que la Filosofía es cognoscitiva (gnoristike), y la Sofística es aparente, pero no real (phainoméne, oûsa d'oú). Metaf. G-2, 1004b 17-20. Extenso comentario de este pasaje de particular importancia en Para leer la Metafisica... op. cit., pp. 210-235 y en El retorno de lo divino griego en la postmodernidad, op. cit, pp. 78-87, en el epígrafe 5, cap. IV. Y el estudio "Parménides entre Platón y Aristóteles. El conflicto de las razones de Occidenten, en El nacimiento de la filosofia en Grecia, op. cit., pp. 239-367.

Dice Aristóteles refiriéndose a la causalidad del bien ontológico y en polémica con el platonismo pitagorizante académico: "Y la que, según vemos, es causa para las ciencias, por la cual actúa todo entendimiento y toda naturaleza, tampoco a esta causa, de la cual decimos que es uno de los principios, la tocan para nada las Especies. Pero las matemáticas son la filosofía para los modernos, aunque digan que deben ser cultivadas en vista de otras cosas" (Metaf. A-9, 992a 25992b). "Tampoco en las matemáticas se demuestra nada mediante esta causa, ni hay ninguna demostración porque algo sea mejor o peor, sino que nadie se acuerda para nada de ninguna de tales cosas, por lo cual algunos sofistas como Aristipo, despreciaban las matemáticas. Pues decían que en las demás artes, incluso en las serviles como la del carpintero o la del zapatero, todo se razona diciendo si es mejor o peor, mientras que las matemáticas no se ocupan para nada de lo bueno ni de lo malo" (Metaf. B-2, 996a 30-996b). 
le a decir que la filosofía no nace sino por la asumpción afirmativa y no castradora de los límites. Tal y como corresponde a su estirpe délfica. Aristóteles no hacía sino prolongar la inicial crítica del mito con que se funda la filosofía desde Mileto hasta Jenófanes de Elea, Parménides, o Anaxágoras, contra las pretensiones escatológicas del platonismo pitagórico de la Academia, y para ello apelaba, como Nietzsche hará también después, al pensar inicial de los presocráticos y a La filosofia en la época trágica de los griegos. Pues ante tales riesgos pavorosos - los de una razón tecnológica secuestrada por los mitos de salvación- sólo (D) una cultura estética: una "Paideía trágica" comunitaria, podría educar el terror a la muerte y su violenta respuesta por parte del hombre, abriendo al mortal al hábito de las virtudes civiles de la paz y la filosofía. No otro es el mensaje central del sabio Aristóteles en la estética de la Poética, ni otro el proyecto de unidad de sentido de toda la vida y obra nietzscheana: la reproposición, contra la violencia prepotente, de una cultura trágica para la educación estética del hombre $^{78}$.

Nietzsche no tenía, pues, más que seguir el señalar (semainein) del Aristóteles griego hacia los filósofos pre-socráticos, para pasar desde la inversión del platonismo a otros planos más afirmativos de la Sabiduría del Eterno Retorno. Circunvalaciones muy profundas de la memoria que se pliegan contenidas por la piel del límite. Otra vez tocaba "aprender a querer hacia atrás ${ }^{79}$ ».

${ }^{78}$ Ha sido Gadamer en Verdad y Método quien ha vuelto a airear el ideal de la tragedia ática como paideía de la pólis, en cuanto generadora de solidaridad y comunidad; pero no puede olvidarse la centralidad de esta temática en Nietzsche y que haya sido el Aristóteles délfico el primero en otorgar a la tragedia ática, en los libros conservados de su Poética, el rango principal y directriz (sobre la epopeya homérica, y sobre los ideales pedagógicos de la República platónica) en cuanto a la educación ciudadana. O sea: la hegemonía, entre todos los saberes y las artes, en orden a la paideía política o educación estética comunitaria, por ser la tragedia teatral aquel arte comunitario por excelencia, cuya kátharsis del temor a la muerte, la envidia, el resentimiento ante la finitud y la desgracia, activados por éleos y phóbos, como desolación y estremecimiento extremos (Cfr. Gadamer: Verdad y Método, op. cit., pp. 174-181) educa en los valores de la ciudadanía y el bien común, porque da lugar a tolerancia, perdón y comprensión. El trazado de esa vía desde el santuario de Delfos a la Poética de Aristóteles; y desde El nacimiento de la Tragedia de Nietzsche y El origen de la obra de arte de Heidegger, hasta la ontología estética contenida en Verdad y Método (Sección II de la I. Parte, op. cit., pp. 143-222), llena de esperanza el alma hermenéutica de Europa. Shiller tenía razón al compendiar el sentido del programa de toda ética política racional, en aquél breve título: "La educación estética del hombres.

79 Para la temática del «salto hacia atrás» (Shritt züruck) puesta en relación con lo no-dicho y no-pensado (un-gesagte, un-gedachte), véase El retorno griego de lo divino..., op. cit.: "La relación Heidegger-Nietzsche con la crítica del nihilismo", pp. 55-67. 
Y tocaba re-escribir hacia el futuro anterior del eco que viene en ayuda del presente: ¡se había vuelto tan irreconocible ya Aristóteles para la cultura filosófica del moderno siglo XIX? ¿Cuánto tiempo habrá de tardar aún nuestra modernidad oficial decadente en reconocer todos los grandes temas de Aristóteles en los provocativos motivos de Nietzsche?: la crítica al monologismo en el centro de la Filosofía primera y la defensa racional del politeísmo henoteísta de lo divino inmanente; la crítica de los excesos del humanismo y la entronización de la phrónesis finita como racionalidad práctico-política en el centro de los libros éticos; la reproposición de una cultura trágica en el centro de la Poética; y la defensa de la inversión ontológica del tiempo cinético en base al eterno retorno, como principio del método de la verdad, orientado por el criterio-crítico de la primacía de la acción teorética (interpretativa, comprensiva y comunicativa: noética) dirigiéndose desde el interior del lenguaje hacia la ontología práctica de la verdadbien misma. Esto último en el centro o alma del sistema (Metafisicos $\mathrm{H}-\Theta$; Etica a Nicómaco; y De anima). Un sistema abierto y explícitamente consciente de ser la primera dialéctica (crítico-dialogal). La priemera hermenéutica (práctica e histórica). Y la primera filosofía intralingüística (de los lógoi) de los saberes de Occidente. De sus regímenes, competencias, mapas de legislación y órdenes del sentido, etc. Esto en el centro de los libros lógicos y los retóricos. Que además estén los libros Físicos, los múltiples biologicos, los meteorológicos o las compilaciones de historía propias de los tratados doxográficos... sólo da alguna idea de la fecundidad del punto de vista adoptado por el perspectivismo propio de los vitalismos espirituales, hablando a favor de las razones de Aristóteles y de las razones de Nietzsche. Los dos grandes descubridores de los filósofos presocráticos, que se sitúan por igual en el emerger creativo de un alto renacimiento justo por hacer suya la post-ilustración. Pues ambos continúan reorientándola hacia atrás, hacia el sentido de sus propias tradiciones..., dos grandes post-modernos situados en la apertura de dos grandes crisis: la de la Ilustración ateniense, tras las Guerras del Peloponeso, y la que afecta a Ilustración europea tras el hundimiento político de la legitimidad de la burguesía que antecede a la "Guerra del 14»: la primera Guerra Mundial europea ${ }^{80}$.

80 Para todo lo relativo al nuevo Aristóteles y su profunda conexión con la hermenéutica actual, a partir de Nietzsche véase Para leer la Metafisica de Aristóteles en el siglo XXI., op. cit., donde se trata esta problemática con todo el rigor crítico-documental que su importancia exige. También puede resultar de utilidad mi artículo "Pierre Aubenque: proximidad y distancia del Aristóteles dialéctico", op. cit. 
Gadamer ya nos lo había enseñado: «Sólo con la edad del romanticismo, el sentido histórico se abre plenamente. El romanticismo despertó una disposición general de tal veneración hacia el pasado, ya primordial, ya oculto o esotérico, que pudo suscitar respecto al inicio histórico del pensamiento occidental un nuevo interés que no se resolvía en establecer una relación de crítica superioridad " ${ }^{81}$.

Y lo cierto es que Nietzsche encontró entre los románticos eso y mucho más: encontró la vía de Hölderin ya a los 17 años, en el gimnasium, cuando intentaba hacerse cargo del dilema originario del idealismo alemán planteado entre el determinismo de Spinoza y la libertad de Fichte: había que devolver al pasado la posibilidad abierta que la historia reservaba sólo a los futuros contingentes. Pues tal noción fixista del pasado cancelaba la condición hermenéutica de la historicidad pasada a expensas de la fragilidad de los documentos que la establecían. Como si no se tratara siempre de decisiones e interpretaciones que se nutren de las polémicas fuentes antiguas. Sólo si el pasado podía ser diverso podríamos ser libres - pensaba ya el joven Nietzsche - y no la consecuencia necesaria de una cadena lineal abrumadora. El primer brote del pensamiento del eterno retorno nace pues en Nietzsche junto con la conciencia hermenéutica de la historia literaria y retórica (estética) de las tradiciones de Occidente ${ }^{82}$. De ahí que el Nietzsche maduro quisiera interrumpir la supuesta necesidad de la violencia del nihilismo reactivo concentrándose precisamente en la crítica y alteración del historicismo progresista y el positivismo cientifista. Los grandes anclajes mitológicos y escatológicos de la Ilustración moderna: la fe en la Ciencia-Técnica, el Progreso, y el sentido emancipatorio o liberador de la Historia de la Humanidad superior. La humanidad escogida: la de origen platónico-judeo-cristiano: la proyectada a ir siempre más allá de los límites de la naturaleza (metà-tà-physiká).

Desde el punto de vista de la crítica contra la violencia de todos esos mitologemas de la salvación secularizada bastaba un solo dardo: mostrar el carácter mitológico del tiempo lineal-causal y matar a la hidra, como Perseo, oponiéndole el espejo de ella misma en todos los puntos mencionados. Retroceder genealógicamente con el método racional-causal de la ciencia hasta los sub-puestos fundamentos atravesables por el método mismo, lo cual disolvía entonces, coherentemente, hasta la propia idea de fundamento asimilada a origen. Y con ello,

${ }^{81}$ H.-G.Gadamer: «I Presocratici), op. cit., pp. 23-24.

${ }^{82}$ Cfr. Gianni Vattimo: "L'impossible oublie", en AA.VV., Usages de l'oubli (Actes du Colloque de Royaumont, 1987), París, Seuil, pp.77-89; y "Nietzsche interprete de Heidegger», en AA.VV., Heidegger; questions ouvertes, Collège de Philosophie, París, Osiris, 1988, pp. 87-97. 
las pretensiones del Sujeto-substancia de la libertad moral junto con la legitimidad racional de su proyecto. La genealogía crítica de Nietzsche es bien conocida. Sólo queremos subrayar que la crítica de Nietzsche muerde sobre el vector temporal-extenso del proceder lógico-matemático racionalista, mostrando que el genetismo inscrito en la dinámica de cualquier lógica de predicados dialéctica afecta a la posibilidad misma de encontrar límites últimos para la división que efectúa el análisis cuando se vuelve hacia atrás. hacia las primeras premisas de las que procede el discurrir por deducción o derivación. Y si ni las relaciones ni los términos pueden sostenerse por no poder encontrar ningún fundamento matemáticamente, habrá que concluir que para la lógica dialéctica que opera por división hasta llegar a los elementos últimos del análisis no hay fundamento posible porque no hay tales elementos y la división de las cantidades lógicas de los predicados, cada vez más universales, puede continuar al infinito. De modo, por lo tanto, que habrá de concluirse que la racionalidad que hace tanto de la lógica y del cálculo matemático como de la causalidad eficiente su modelo no puede encontrar ningún fundamento último racional posible, pues la propia noción de fundamento o sujeto no es sino un predicado divisible que no puede detener el análisis y ponerse en el sitio de la causa primera.

Mostrar, así, la debilidad o impotencia de la lógica de la eficacia y la fuerza, al desenmascarar precisamente su carácter potencial-dinámico infinito, está en el centro de la crítica genealógica de Nietzsche al sujeto moral metafísico y al sujeto racional de la tradición humanista cristiano platónica. Es cierto, pero la verdad es que carece de importancia, comparado con la cuestión radical implicada por esa misma crítica, por la cual se disuelve también la legitimación de $\mathrm{La}$ Historia Universal, ya en su papel de fundamento unitario o superficie de inscripción de los fenómenos, ya como decurso causal, ni progresivo ni regresivo, ya incluso como discurso racional. Pues la racionalidad causal, asimilada a la lógica genealógica de la fundamentación originaria, sigue rigiendo en la deducción axiomática que es propia del metodologismo de la ciencia moderna. Conociera o no Nietzsche exactamente la misma crítica en Aristóteles contra la Dialéctica tentativa (peirastiké) de Platón como meramente potencial (dynámę) ${ }^{83}$, el alcance de la misma se vuelve algo extraordinario y estremecedor, sencillamente descomunal y terrible, cuanto más crece el modelo inflado. Es decir: cuando esa misma crítica es aplicada a la larga historia del platonismo siempre en expansión por

83 Véase supra, nota 69. 
división infinita, y se localiza en el esquema el mismo método elemental de la historia de la metafísica-ciencia-técnica. Este último vector lo explicitará luego Heidegger poniendo en evidencia el proceso mitológico de la racionalidad occidental triunfante: la infundada racionalidad del nihilismo globalizador, donde se subsumen todas las diferencias ${ }^{84}$.

Que no todas las dimensiones del nihilismo sean rechazables para Nietzsche, en virtud de la ontología estética-hermenéutica que ofrece como alternativa al positivismo y al historicismo metafisicos, ha de tomarse muy en serio, precisamente desde el punto de vista de la hermenéutica postmetafísica por él abierta como racionalidad postmoderna actual. Pero la intervención nietzscheana no puede entenderse cabalmente si no se tiene en cuenta más que su crítica. En efecto, el interés de la crítica de Nietzsche estriba precisamente en cómo resulta inseparable de su alternativa filosófica. Ahí está la profunda coherencia y unidad de estilo que sólo vamos percibiendo lentamente en nuestros días ${ }^{85}$. ¿Y está ahí lo que buscábamos? Porque, para decirlo de una manera algo provocativa y algo rápida ahora, esa alternativa se llama sencillamente «Heráclito»; y para decirlo de modo completo, es la alternativa de la hermenéutica presocrática. La que hemos llamado referencia presocrática, si se tienen en cuenta todos los vectores de modificación de la racionalidad hacia su configuración hermenéutica que este estudio ha ido recorriendo a lo largo de las páginas anteriores. En relación, sobre todo, al ser del tiempo y la historicidad, al lenguaje, a la subjetualidad noética, y a la reproposición de una cultura trágica o una cultura estética como cultura de la paz civil. En esa pragmateía se señalan ya los giros que irá desgranando, matizando y descubriendo el pensamiento hermenéutico contemporáneo de Los

${ }^{84}$ Dice Aristóteles: «Pero si el bien fuera El Uno, el Mal sería entonces la naturaleza de la Pluralidad (...) resulta entonces que todos los entes participarán de la naturaleza del Mal excepto Uno, que es el Uno en sí (...). Y el Mal será el lugar del Bien, y participará y tendrá ansia de lo que tiende a destruirlo, pues un contrario tiende a destruir a otrom, (Metaf. N-4, 1091b 34-1092a 2). La crítica de la violenta inversión que operan los monologismos y fundamentalismos identitarios de todo tipo, encuentra en la reductio ad absurdum del elegktikôs aristotélico contra la Academia, momentos de una premonición histórica estremecedora.

${ }^{85}$ Gracias a la Hermenéutica de Heidegger, y Gadamer y Vattimo, que lo continúan críticamente; pero sobre todo en este punto relativo al reconocimiento del estatuto radicalmente ontológico del pensamiento de Nietzsche, que no puede ser reducido a una mera críica de la cultura, gracias a la ontología asombrosa de Gilles Deleuze, quien de sí mismo sólo afirma ser un nietzscheano y nada más que un nietzscheano. (Véase el Prólogo a la ed. española del libro de G. Vattimo: Diálogo con Nietzsche, op. cit., pp. 11-27. 
bijos de Nietzsche, hasta llegar a Gadamer y a nosotros: el giro lingüistico, el hermenéutico, el ontológico, el espiritual y el estético. Tal es el alcance de la referencia presocrática nietzscheana si se tiene en cuenta su producción de conjunto: desde El nacimiento de la Tragedia hasta el Asi habló Zaratustra o El Anticristo. Pues tanto la apelación a Dionisos como la reproposición de una paideía estético-trágica, la inversión del platonismo o la tesis del Eterno Retorno, por ejemplo, son constantes motivos contrasocráticos, que se proponen y operan una alteración de la metafísica platónica y su historia. Tanto como lo hacen los escritos críticos de la llamada «época ilustrada de Nietzsche»: Humano demasiado humano, La gaya ciencia, La genealogia de la moral o Las consideraciones intempestivas.

Por contraste con la enseñanza del Nietzsche devenido filósofo presocrático heracliteo él mismo, cada vez de un modo más firme desde El Nacimiento de la Tragedia hasta el heraclíteo sabio Zaratustra, la contribución de Friedrich Nietzsche a la hermenéutica académica de los presocráticos sería muy escasa ${ }^{86}$. Nietzsche no lee ni enseña a Anaximandro, como sin duda lo leerá después Heidegger, ya en términos de ontología del ser del tiempo, puesta en relación con el límite y el lenguaje, sino que proyecta sobre el milesio la errada manera pesimista propia del marco general del orfismo y más bien, entonces, lo lee en consonancia con Schopenhauer, cuya sombra hace planear sobre el sabio jonio, cubriéndolo

${ }^{86}$ Cfr. F. Nietzsche: La filosofía en la época trágica de los griegos. Trad. castell. Valdemar, 2. ${ }^{a}$ ed, Madrid, 2001. En efecto, si tuviéramos que juzgar por el único texto suyo didáctico que la contiene: La filosofia en la época trágica de los griegos (ed. cit.), perteneciente a la misma época temprana que El nacimiento de la Tragedia y las lecciones de Basilea sobre la misma materia, habríamos de concluir que, en realidad, con la única excepción del deslumbrante descubrimiento de Heráclito el obscuro, Nietzsche repite aquí los tópicos de la historia de los presocráticos devenida banal en manos de los positivismos fisicistas decimonónicos, en ocasiones contrarrestados por un espiritualismo mítico-orfizante propio de las lecturas románticas, por ejemplo, cuando se trata de Anaximandro o de Empédocles. En cuanto a Anaximandro, en concreto, ha sido discutido de modo decisivo por Werner Jaeger en la Teologia de los Filósofos presocráticos tanto la lectura de Niezzsche como la de su amigo Edwin Röhde, el autor de Psyché, quienes ignoraban el término "allélois» en el tramo del texto indiscutiblemente fidedigno de la sentencia de Anaximandro que debemos a Simplicio, lo cual les conducía a interpretar en sentido órfíco y pesimista como ofensa y culpa originaria hacia el Uno-Todo matricial indiviso, cualquier nacer al dividirse y desgarrarse la unidad por parte de lo múltiple enfrentado y concurrente. Restituir al texto el allélois orienta decisivamente la adikia o injusticia de los presentes tà ónta hacia los otros (allélois) ausentes; y permite así enlazar la coherencia inteligible (kyklos) de los nacimientos y las muertes, según la disposición del tiempo (katá tèn tồ chrónou táxin). Vésase sobre Anaximandro mi estudio: «La actualidad del pensamiento presocrático» en El Nacimiento de la Filosofia..., op. cit., pp. 15-27 y «Hacia Mileto", ibíd., pp. 27-149, especialmente p. 95 y ss. 
de una supuesta melancolía del origen que el propio Nietzsche termina después por despreciar. Pero tampoco Parménides es redescubierto por Nietzsche, quien repite a propósito del sabio eléata los tópicos imposibles del monismo numérico del ser uno cardinal e inmóvil, quietista, sin abrirse a la consideración modal intensiva del uno-mismo simple e indivisible como acción (que no es ni reposo ni movimiento, ambos contrarios entre sí). La misma acción-límite común del pensar y el ser, situada en el ámbito del arché. Será Heidegger quien lo redescubra, testimoniando la radical coherencia de Parménides, al seguir hacia atrás sus huellas por la senda de Aristóteles, mientras redescubre, a su vez, la profunda unidad que enlaza entre sí la ontología de Parménides y la de Heráclito, contra la persistente versión dicotómica que los enfrenta a partir de una doble y tosca caricatura: la del Heráclito movilista y el Parménides quietista. Tal pensamiento de la unidad-mismidad diferencial entre los dos ontólogos presocráticos estará también en el centro de la ontología hermenéutica de Gadamer, mientras que Nietzsche, sin embargo, escribe aún lo siguiente:

Ambos filósofos observaron repetidamente el mundo que Anaximandro había condenado casi melancólicamente y que declaró lugar de crimen e iniquidad a la vez que lugar de expiación de las injusticias del devenir. En su contemplación de este mundo Heráclito descubrió -como sabemos-qué orden tan admirable y qué regularidad se revelan en el devenir; de ahí dedujo que dicho devenir en cuanto tal no puede ser considerado simplemente como algo criminal o injusto. Una mirada muy diferente es la que vierte Parménides (...) en la quietud mortal, en la gélida rigidez de ese concepto de «ser», un concepto vacío y que no dice nada (...) Contra esto no hay escapatoria alguna, es completamente imposible definir el pensamiento como algo permanente y fijo, como un pensarse-a-sí-mismo —eterno e inmóvilde la unidad (...) Poseemos de la manera más inmediata posible la evidencia intuitiva de la verdad del movimiento y de la sucesión únicamente por el mero hecho de que pensamos y tenemos representaciones. En todo caso, se ha de apartar a un lado a ese ser uno, rígido, inmóvil, muerto, de Parménides: existe una multiplicidad de seres y esta convicción es tan cierta como que tal multitud de seres (existencias, substancias) se hallan en movimiento ${ }^{87}$.

${ }^{87}$ F. Nietzsche: La filosofia en la época trágica..., op. cit., pp. 79, 87, 95, 99. 
Así pues, poco o nada ha comprendido Nietzsche de Parménides, igual que poco o nada había comprendido de Anaximandro; y en cuanto a los Pluralistas resulta muy significativo destacar cómo proyecta en Anaxágoras la Metafísica del artista y del genio, que luego le reprochará Heidegger, una vez más siguiendo a Aristóteles. Nietzsche, en efecto, parece enteramente ajeno al factor nihilistamitológico que anida en la téchne cosmogónica cuando escribe:

Pero el más grande seguidor de Anaxágoras fue Pericles, el hombre más poderoso y noble del mundo; Platón se refiere precisamente a él alegando que fue únicamente la filosofía de Anaxágoras la que proporcionó alas sublimes al genio de Pericles. Cuando como orador público se presentaba ante su pueblo (...) hablaba, tronaba, fulminaba, arrasaba y salvaba (...), entonces encarnaba él mismo la abreviatura del cosmos anaxagórico, era la viva imagen del noûs que ha construido para sí la indeterminación característica más bella y digna de las moradas, y, por así decirlo, parecía la encarnación visible de la fuerza constructiva del espíritu, fuerza motriz que selecciona y ordena, que abraza un vasto horizonte y que conserva la del artista (...); esta voluntad absolutamente libre sólo puede pensarse como carente de finalidad, aproximadamente como un juego de niños o un divertimento artístico ${ }^{88}$.

Motivos, sin embargo, que se han de prolongar y radicalizar, para estar a la altura de la ironía de Nietzsche, desde las manos del poder hasta el volar de las palabras y el tocar de la verdad. O sea: hasta lograr el sobrepasamiento del sujeto, tal y como sí sucede en Heráclito. Este sí estando ya en plena consonancia con Nietzsche, porque los motivos del arte han logrado transformarse e inscribirse en una ontología trágica de la inocencia y el juego, ajena a toda voluntad escatológica y toda cosmogonía. Así dibuja Nietzsche la imagen de Heráclito, el intempestivo solitario, el altivo, en que ya se presiente y prefigura desde un texto tan temprano como La filosofia en la época trágica de los griegos la inquietante figura de su eremita Zaratustra, el maestro del eterno retorno, viniendo de las altas montañas:

Sólo podrá adquirirse una ligera idea del sentimiento de soledad que embargaba al eremita efesio del templo de Artemisa si se observa la extraordinaria desolación de la más desierta de las montañas. A él no le arrebata 
ningún sentimiento prepotente de compasión, ni tampoco le conmociona deseo alguno de ayudar, de salvar o liberar a los demás (...) entre los hombres, Heráclito fue en tanto que uno de ellos, increíble; y si se le veía prestar atención al juego de unos chiquillos bulliciosos, pensaba algo en lo que jamás pensó hombre alguno contemplando la misma escena: en el juego del gran niño cósmico, en el juego de Zeus (...). «Me busqué y me investigué a mí mismo», dijo de sí usando unas palabras que se atribuyen a una consulta oracular, dando a entender que es él, y ninguno de los demás hombres, quien satisface y consuma de verdad el precepto délfico "Conócete a ti mismo». Lo que él oyó del oráculo lo consideró inmortal, además de sabiduría eterna digna de ser eternamente interpretada y de innegable efecto para todas las generaciones venideras, a semejanza del ejemplo de los discursos proféticos de la Sibila. Tal sabiduría es suficiente para la Humanidad venidera, que habrá de interpretarla como si tratara de sentencias oraculares del dios délfico "que no dice ni oculta». Aunque sus vaticinios se anuncien «sin sonrisas, sin ornamentos ni sahumerios" y más bien "con boca delirante", deberán incidir en los milenios venideros. En efecto, el mundo necesita eternamente de la verdad; he ahí por qué necesita eternamente a Heráclito. (...) Aquello que él observó - la doctrina de la ley del devenir y del juego en la necesidad-debe ser, a partir de ahora, contemplado eternamente: Heráclito ha alzado el telón de tan inmenso espectáculo ${ }^{89}$.

Casi estamos ya oyendo a Gadamer que hará profundamente suyas tales palabras, situándose mucho más cerca del Nietzsche-Heráclito trágico de lo que nadie hubiera podido imaginar en un principio. Pero, de todos modos, ¡qué alcance profético el de la fundación délfica y heraclítea de la hermenéutica en estos pasajes del joven Nietzsche!: un volver a nacer de la filosofía; un renacer de la filosofía; de eso se trata en la inmensa apertura que Nietzsche descubre y transmite en La filosofia en la época trágica de los griegos, donde de todos los presocráticos sólo llega a poder comprender a Heráclito, quedándose deslumbrado, transfigurado, por la vuelta al origen délfico de la sabiduría de los límites que acontece sin mediación ni génesis en los aforismos del obscuro rey filósofo. El que renunció al poder para consagrarse a la belleza, la bendición de la inocencia del devenir; el ígneo canto de la unidad que es pluralidad, y la inmersión en el alma insondable, has-

${ }^{89}$ Ibíd., pp. 73-75. 
ta allí donde los espíritus de los muertos resucitan en lo más profundo del lógos inmortal... Heráclito el obscuro en cuyos aforismos forjados a fuego se traza la topología de la luz y el calor de la vida-muerte, en la tierra celeste alumbrada por el puente del rayo que permite ver la luz y la noche a la vez. El sagrado sacerdote de Apolo y Dionisos, declarando la inocencia trágica de la verdad. Incipit Hermenéutica: la hermenéutica contemporánea postmoderna, como renacimiento trágico-estético de la filosofía griega originaria, acaba de abrirse en cuanto epocalidad del ser. La han abierto Hölderlin y Nietzsche resucitando los textos de Heráclito que vierten el señalar esencial del filosofar hacia su ley. Así lo dice Nietzsche en La filosofia en la época trágica de los griegos:

Otros pueblos tienen santos, los griegos tienen sabios. Con razón se ha dicho que un pueblo no se caracteriza tanto por sus grandes hombres como por la manera en que los reconoce y venera. En otras épocas el filósofo se presenta como un peregrino solitario y accidental marchando al azar a través del más hostil de los ambientes, o bien pasando inadvertido y sigiloso, o bien abriéndose paso con los puños apretados. Sólo entre los griegos no es accidental el filósofo (...) los griegos legitimaron la filosofía (...) todo filosofar moderno es pura apariencia erudita; es pura política, y es policial; lo mediatizan gobiernos, iglesias, academias, costumbres, modas y cobardías humanas (...) la filosofía carece de legitimidad, por eso si el hombre moderno fuera valiente y honesto, tendría que rechazarla y proscribirla con palabras parecidas a las que usó Platón, para apartar de su ciudad ideal a los poetas trágicos. Sin duda alguna, igual que los poetas trágicos contra Platón, también a la filosofía le queda aún el recurso de la réplica. Si se la obligase a hablar podría aducir algo semejante a esto: «OH, pueblo desafortunado! ¿Es acaso mi culpa si como una hechicera debo vagabundear por los campos y esconderme y disimular como si fuera una pecadora y vosotros mis jueces? Mirad a mi hermano el arte: le va como a mí; hemos venido a parar entre bárbaros y ahora no sabemos ya cómo librarnos de ellos. Aquí carecemos a decir verdad de toda legitimidad; pero los jueces ante los que clamamos por nuestros derechos también habrán de juzgaros a vosotros y os dirán: ¡Tened primero una verdadera cultura, entonces comprenderéis qué pretende la filosofía y cuál es su poder!,»" 
Un espacio público de legitimidad para la verdad y el arte no sometidos ni a los tráficos del poder ni a la elemental reducción de la violencia bárbara y su repugnancia por los lenguajes complejos de la vida-muerte. De eso se trata con la reproposición de una cultura trágica-hermenéutica por parte de Nietzsche: de hacer renacer la filosofía y el arte como paideía ciudadana, volviendo a poner la ley-límite del lógos, como en Delfos y en la Jonia presocrática, en medio de la plaza pública: es tò koinón, es tò méson. Como lo común, el criterio y la medida de la cultura. De volver a poner como en la tragedia ática, el misterio trágico en medio del teatro de la paideía de la pólis. Incipit Traogedia. Incipit Hermenéutica. Tal es la antorcha que nos lega el Nietzsche presocrático heracliteo.

\section{II.1.b. Heidegger y los presocráticos}

¿Y qué decir de Heidegger? No está en nuestra voluntad privar al lector/a de estas páginas de la más honda y hermosa literatura filosófica que haya producido el siglo XX: los textos presocráticos de Heidegger. Los que ponen en obra el pensar del ser-tiempo, filosofando con Anaximandro, Parménides y Heráclito, a partir del descubrimiento de sus claves hermenéuticas gracias a Nietzsche y a Aristóteles. Desde ellos, los primeros ontólogos del lenguaje, no conoce la filosofía occidental una cumbre semejante a Heidegger, ni una similar exigencia. Pues no se puede acceder a estos textos - tanto a los de Heidegger como a los griegos- que guardan cifrado su sentido a pesar de estar aparentemente abi expuestos como cualquier escritura, sin darse el receptor verdaderamente la vuelta hacia lo otro del ente. Hacia la experiencia de la verdad del ser, ajena a toda doctrina o doxática. Ahí donde no tiene cabida ninguno de los esquemas representacionales de la razón judicativa: los sujetos, los objetos y sus tribunales de cuentas y cálculos, sino el acontecer del darse del tiempo y el ser como lugar de la verdad, para decirlo con las palabras mismas del filósofo alemán. Acontecer (Ereignis) que se da pensando con Heidegger en la experiencia de una disposición donde se solicita la implicación de la subjetualidad, intensamente concentrada en la recepción virtualizante del escuchar, y casi se rompe el lenguaje. En los bordes del lenguaje, en sus límites, aún participables y comunicables. Tal es el caso, por ejemplo, de escritos como La sentencia de Anaximandro en la colección de los Holzwege (Caminos del bosque ${ }^{91}$; los

91 M. Heidegger: "La sentencia de Anaximandro" (1946) en Caminos del bosque. Trad. Helena Cortés y Arturo Leyte. Ed. Alianza, Madrid, 1995, pp. 290-336. 
Vorträge und Aufsätze (Conferencias y artículos) que contienen la tríada heracíteoparmenídea: Lógos, Moîra, Aléteheia ${ }^{92}$; el curso monográfico lectivo intitulado Parménides $^{93}$; el seminario Heráclito ${ }^{94}$, o la conferencia Zeit und Sein (Tiempo y Ser) ${ }^{95}$. Texto, este último, decisivo, en que Heidegger vuelve a pensar la filosofía de la historia en discusión con la dialéctica de Hegel, y a partir del «tò gàr autò noeîn estín te kaì eînaì del Poema de Parménides. En este escrito se ofrece, tras la köhre, la clave de bóveda del propio itinerario de Heidegger iniciado en Ser y Tiempo.

Detengámonos un momento en este breve texto como muestra del Heidegger presocrático. Se trata de un escrito redactado a partir de una conferencia pronunciada en la universidad de Friburgo en 1962, a la que Heidegger dedicó un seminario algunos meses más tarde, recogido en parte después en otro singular escrito: Protocolo de un Seminario sobre la Conferencia «Tiempo y Ser" ${ }^{96}$. Si tal texto ha de destacarse entre todos los de la excelente producción del que llamamos "último Heidegger» después de la Köhre o vuelta de su pensar - fechable hacia la mitad de los años $30 \mathrm{y}$, consecuentemente, tras la bancarrota espiritual que supuso para Heidegger la comprensión de su propio error político, siempre imperdonable para sí mismo ${ }^{97}$-, es porque contiene la última ontología del filósofo.

${ }^{92}$ M. Heidegger: Conferencias y articulos (1954), op. cit. Véanse las secciones: «9. Lógos. Heráclito fragmento 5", pp. 153-169; «10. Moira. Parménides VIIl, 34-41", pp. 171-189; y «11. Aléheia. Heráclito, fragmento 16m, pp. 191-208.

${ }^{93}$ M. Heidegger: Parménides (Curso del Semestre de Invierno del año 1942-43, impartido en la Univ. de Freiburg). Fue publicado póstumamente en el vol. 54 de la Gesamtausgabe. Vittorio Klostermann, Frankfurt am Main, 1982. Contamos con una excelente edición crítica de su traducción al inglés, comentada y anotada con sumo cuidad por André Schuwer and Richard Rojcewicz: Martin Heidegger, Parmenides. Indiana University Press. Bloomington and Indianápolis, 1998.

${ }^{94}$ Martin Heidegger, Eugen Fink: Heráclito (Seminario del Semestre de Invierno, Universidad de Freiburg). 1. ${ }^{\circ}$ Ed. Vittorio Klostermann, 1970. Trad. española Jacobo Muñoz y Salvador Mas. Ed. Ariel, Barcelona, 1986.

${ }^{95}$ Ambos escritos se incluyen en M. Heidegger: Zur Sache des Denkens. Max Niemeyer Verlag Túbingen, 1976, pp. 1-60. Hay trad. castellana de M. Garrido en: Tiempo y ser. Ed. Técnos, Madrid, 1999, pp. 19-77.

${ }^{96}$ Ibíd., ed. alemana, pp. 27-60; ed. española, pp. 45-76.

${ }^{97}$ Dice Heidegger: «Pero el acusado hizo una señal negativa. Uno tiene que comparecer, dijo, cuando es llamado. Pero llamarse uno a sí mismo es la cosa más absurda que pudiera hacerm. Así de enigmáticamente termina el escrito Protocolo de un Seminario sobre "Tiempo y Ser» (op. cit., p. 74), el texto donde culmina su Kehre, el darse la vuelta o la conversión de su propio pensar desde la subjetualidad judicativa hasta la inocencia del ser; desde la hybris del sujeto ilustrado moderno que erige la racionalidad-libertad de la subjetualidad soberana, como suprema autonomía legisla- 
En efecto, en la conferencia "Tiempo y ser" se logra alcanzar a decir lo que no podía ser dicho, según declaraciones del propio Heidegger, en la obra que lo lanzara al reconocimiento universal: Ser y Tiempo del año 1927. Recuérdese que su última parte no pudo ser escrita porque a juicio del propio Heidegger el acceso al ser no podía darse por impedírselo el estar todavía pensado, Ser y Tiempo, desde los esquemas de la metafísica subjetualista. Y ello a pesar de cómo estaba intentando ya, aquella obra, pensar el ser del Dasein o Ahi del Ser, asimilado entonces al hombre en cuanto mortal que ha asumido su condición extática, abierta al $\operatorname{ser}^{98}$. Dice muy significativamente Heidegger, culminando el proceso de la Köhre, en Zeit und Sein: "El intento abordado en Ser y Tiempo (\$ 70) de reducir la espacialidad del estar humano a la temporalidad ya no se deja mantener" $"$.

Todas las cuestiones mencionadas guardan una estrecha relación entre sí, y se reúnen en una honda claridad sincrónica en cuanto se comprende que Tiem-

tiva, en la instancia incondicional y transcendental de todo juicio, hasta la serenidad de la apertura y el desasimiento de aquéllos aforismos de Heráclito: "Como polvo esparcido al azar es el más hermoso kósmos» (Teofrasto, Met. 15, DK 22 B 124), «A lo que jamás tiene ocaso ¿cómo podría uno ocultársele?" (Clemente de Alejandría, Pae. II 99, DK 22 B 16) (nuestra trad. en El nacimiento de la Filosofia, op. cit., p. 203). En nuestra opinión se debe buscar la explicación de que Heidegger no encontrara sentido ni a perdonarse a si mismo ni a pedir perdón públicamente, en la radical coherencia de su propia trayectoria filosófica y en la primacía que tiene para su pensamiento la ontología hermenéutica de la acción noética. Lo cual dicho más sencillamente se traduce en que consideraba su deber, y su única expiación posible del error, el dar lugar efectivamente a preparar un pensamiento por la paz. Y a ello se entrega por completo su Hermenéutica, abriendo otra (y no una "nueva») epocalidad para Occidente. ¡No es nada fácil! Pero sí es el ideal más coherente y más hermoso de Occidente. En ello estamos. En ello anda la filosofia postmoderna y las Izquierdas que han sabido despedirse de Marx y de los dogmas de la Ilustración Moderna, tanto como de las democracias (¿) belicistas en la era del terrorismo de la globalización. Aún parece tener que decirse en voz baja pero cada vez irá resultando más consciente para el socialismo europeo y occidental que la vía alternativa a la barbarie nihilista del capital ilimitado es la Hermenéutica Postmoderna. La vía de las culturas posthistóricas, el pensamiento crítico y las instituciones de la paz y el bienestar social, que es la vía abierta por Nietzsche, Heidegger, Gadamer y Vattimo, además de por el postestructuralismo francés, el pensamiento trágico español y los movimientos ecologistas en todo el planeta. Véase en relación a lo que se puede llamar la Cuestión del perdón en Heidegger, el comentario sobre "La frase de Heidegger: Sólo un dios puede salvarnos", en la famosa Entrevista póstuma del Spigel. Cfr. El retorno de lo divino griego..., op. cit., nota 37, pp. 299-303.

${ }_{98}$ Véase, sobre la Kehre y su sentido, desde la propia autointerpretación documental de Heidegger, mi artículo: "La cuestión del sujeto en el pensamiento de Martin Heidegger», en la revista de filosofía Anales del Seminario de Metafisica, Fac. de Filosofía UCM, Madrid, 1984. También de Julian Young: Heidegger's later Philosophy. Cambridge Univ. Press., 2002, especialmente pp. 7582.

${ }^{99}$ M. Heidegger: Tiempo y Ser, op. cit., p. 43. 
po y Ser solo vuelve a pensar a Parménides: al «tò gàr autò noeîn estín te kaì eînaì de la alétheia de Parménides, como destinación incumplida y nunca-pensada que se alberga para nosotros precisamente tapada por lo dicho y pensado en su nombre: el racionalismo, el idealismo, el monologismo... Volver a pensar lo Ungedachte y lo Ungesagte del Poema de Parménides como inicio de la ontología nometafísica occidental, después de la Köhre y de la hybris o demesura de la aventura nazi, involucrada en la metafísica de la voluntad de voluntad o libertad absoluta propia de la voluntad de potencia del hombre, como culminación del idealismo moderno y desembocadura consecuente de la historia racionalista-progresista de Occidente. Volver a pensar a Parménides supone, después de Auschwitz e Hiroshima, un salto hacia el otro inicio de Occidente, siempre ya posibilitado por los mismos documentos de la escritura que registra nuestra memoria de la verdad. Pero tras la supina violencia del supino extravío de la historia metafísica que se cumple tras la ciencia-técnica en el emplazamiento (Gestell) del nihilismo planetario global, como olvido consumado del ser. Bastante duro el testimonio auto-crítico del Heidegger moderno. Enteramente inaceptable e inaceptado aún por parte de la neo-ilustración moderna hegemónica y su siempre autocomplaciente autoconciencia de sí misma. Pues los neoilustrados modernos, desde el poder de la conciencia oficial que se remonta para Occidente al organigrama de fuerzas políticas trazado a partir de la Segunda Guerra Mundial, en tanto en cuanto lo sean y en el grado y modo en que lo sean y pertenezcan a ese mundo, no podrán entender ni entienden todavía en general una sola palabra del «Segundo Heidegger" o "Último Heidegger": el Heidegger presocrático ${ }^{100}$. Por eso le ridiculizan y se mofan, como ha hecho siempre la ignorancia irritada contra lo que no puede consumir. Sólo la postmodernidad, como época hermenéutica del ser, puede hacerse cargo de la radical experiencia filosófica trazada por Heidegger: volver al origen de una memoria virtual donde los más antiguos de nuestros textos permiten la apertura ahora de otro lugar-lenguaje. Otro ahi del ser donde desde el inicio se abría ya otro espacio-tiempo para otra época de la verdad. Una época donde sí es posible la complejidad serena e intensa de la paz.

${ }^{100}$ Me ha alegrado comprobar una amplia sintonía interpretativa respecto de este mismo enfoque postmoderno de Heidegger en los trabajos de Julian Young y en especial en su último escrito aparecido: Heidegger's later philosopy. Cambridge, Univ. Press., 2004. También Joan Stambaugh, traductor de Zeit und Sein al ingles para la Chicago University Press, termina su "Introducción" al texto de Heidegger invocando la hermenéutica délfica de la divinidad en los aforismos de Heráclito. Cfr. Martin Heidegger: Time and Being, translated by Joan Stambaugh. Chicago. Univ. Press., 2002, "Introduction", pp. VII-XI. 
Desde los Beiträge zur Philosophie (vom Ereignis) ${ }^{101}$ Heidegger no ha hecho otra cosa que entregar por entero su vida y su obra a preparar un pensamiento por la paz, obteniendo lúcidamente como ningún otro testigo, las consecuencias inequívocas del Holocausto, en todas sus direcciones, y llevando hasta el final la crítica de la civilización. Civilización que hoy prosigue el belicismo de la barbarie y el genocidio sistemático de las diferencias, reproduciendo la venganza infinita de los monologismos... eso sí, cada vez más a pesar de la koiné hermenéuti$c a$ de la filosofía, que denuncia su total falta de legitimidad y la inverosimilitud en que han caído su grandes metarrelatos ${ }^{102}$.

En relación a Gadamer, discípulo de Heidegger, y a cómo continúa los caminos abiertos por éste, se ha de subrayar de modo sucinto lo siguiente: que si Tiempo y Ser destaca por el excepcional esfuerzo comunicativo hacia el sentido de la Köhre y la trayectoria del itinerario de Heidegger hacia los presocráticos, de la mano de Parménides y tendiendo la mano a Parménides, no son menos esenciales respecto del inédito retorno a los orígenes nunca pensados de nuestra memoria documental los otros escritos antes mencionados. Textos tales como los Vorträge und Aufsätze, que se sitúan en un "ecuador medio" por así decirlo, de la producción heideggeriana; o volúmenes como el Parménides de los años 50, y sobre todo el Heráclito que recoge un Seminario de Heidegger de mediados de los 60. Dicho seminario se celebró, concretamente, durante el invierno de 196667, en la universidad de Friburgo, donde el filósofo junto con Eugen Fink vuelve una vez más a investigar, en el seno de la academia y en diálogo con los estudiantes de filosofía, el sentido de los aforismos del lógos del Efesio, vinculados por Heidegger con una lucidez estremecedora a la mismidad del uno (hén) indivisible del pensar (noeîn) de Parménides. Los dos ontólogos griegos, a saber: Par-

${ }^{101}$ M. Heidegger: Beiträge zur Philosophie (Vom Ereignis) (1936-38), Gesamtausgabe, vol. 65. Vittorio Klostermann Verlag, Frankfurt am Main, 1989. Trad. española de DINA V. Picotti. Ed. Almagesto, Buenos Aires, 2003. En relación a la kehre, véase el "Epílogo del editor alemán», o sea: de F.W. von Herrmann, op. cit., pp. 403-410. Hemos dedicado al Heidegger presocrático otro escrito. Se trata de "I a diferencia dislocada: Nietzsche, Heidegger y los griegos" y ocupa un lugar central dentro de El retorno griego de lo divino en la postmodernidad, op. cit. Allí encontrará el lector/a referencia pormenorizada de los motivos, elaboraciones, obras y literatura crítica relativos tanto al Heidegger presocrático como al Heidegger lector de Aristóteles, puesto en relación de contraste crítico con la hermenéutica de Nietzsche, la cual Heidegger continúa también hacia los primeros filósofos y la experiencia originaria inagotable del pensar del ser.

${ }^{102}$ Cfr. J. François Lyotard: La condición postmoderna, La postmodernidad explicada a los niños, Le differend. 
ménides y Heráclito, han dicho lo mismo (tò autô): la unidad indivisible del límite intensivo $o$ inextenso como principio constituyente de la experiencia indivisible del pensar del ser-tiempo-espacio. Mismidad que Heidegger elabora ahora como unidad tetradimensional del tiempo-espacio que se da en sincronía diferencial del pasado, futuro y presente, reunidos, por el espacio de su diferencia, en el Ereignis. en el Acontecer expropiador e indisponible de esa misma diferencia transversal, que es alcanzada por el lenguaje, abriendo, cada vez, el lugar de la verdad (alétheia) como misterio del ocultamiento y des-ocultamiento a la vez. En medio de la síntesis disyuntiva de los extremos máximamente tensados y enlazados por su diferencia: el pensar espiritual del noein del mortal que interpreta el inagotable darse (sustraerse) del Acontecer expropiador. Dice así Heidegger, en diálogo con Hölderlin y con Nietzsche, con Parménides y con Heráclito, en los últimos párrafos del Protocolo de un seminario sobre "Tiempo y Sen", en los que se ocupa de nuestra situación hermenéutica después de la Köhre.

Cabe, pues, decir que la historia del ser es la historia del creciente olvido del ser (...), que cuanto más se aleja uno del alba del pensar occidental, de la alétheia, tanto más cae ésta en el olvido, tanto más inequívocamente emerge el saber, la consciencia, y se retira así el ser. Esta retirada del ser permanece, además, oculta. En el kryptesthai de Heráclito es por primera y última vez expresado lo que es la retracción. El retirarse de la alétheia como alétheia da paso franco a la enérgeia, a la actualitas ${ }^{103}$, etc. De este significado de trans-

103 En relación a Heidegger y Aristóteles, se deben consultar dos imprescindibles monografías. La primera de ellas se debe a Franco Volpi: Heidegger e Aristotele, Padua, 1984. La segunda a Enrico Berti: Aristotele nell novecento, Roma, Bari, 1992. Y en cuanto a Heidegger mismo dice así: "Esta sería la ocasión de determinar la posición fundamental de Aristóteles en la metafísica. A tal fin no basta sin embargo con operar una mera contraposición a Platón, ya que Aristóteles todavía por última vez y por medio de atravesar precisamente la metafísica platónica, trata de pensar el ser al modo originariamente griego, e intenta retornar desde dentro, por así decir, al detrás del paso efectuado por Platón, con la Idea del tou Agathou, para quien la onticidad (ousía) recibe la determinación de aquello que la condiciona y capacita, es decir: de la dynamis. Por el contrario Aristóteles piensa el ser de un modo más griego que Platón, si se puede decir así, esto es: como enérgeia (...). Qué signifique esto es algo que no puede resumirse en pocas palabras. Hagamos sólo notar que Aristóteles no es ni un mero platónico fracasado, ni un precursor de Tomás de Aquino. Su obra filosófica no se resuelve ni mucho menos, en el conjunto de sinsentidos que con frecuencia le son atribuidos, a comenzar por el supuesto haber hecho descender las Ideas de Platón desde su En-sí hasta las cosas mismas. La Metafísica de Aristóteles, no obstante la distancia del inicio de la filosofía griega, es, en aspectos esenciales, de nuevo, una suerte de relanzamiento orientado hacia el adentro del inicio del pensar griegon. M. Heidegger: Nietzsche, Phullingen, 1961, vol. II, p. 28. 
formación dicho con referencia a la metafísica, hay que distinguir con nitidez aquel otro que es mentado cuando se habla de que el ser es transmutado en Acontecer expropiador. Aquí no se trata de una manifestación del ser comparable con las figuras metafísicas del ser —a las que se pudiera añadir como si fuese una nueva figura que lo siguiera-. Lo mentado con ello es más bien que el ser - y con él sus manifestaciones epocales- es contenido en el destino, pero cancelado como destino en el Acontecer expropiador.

Entre las figuras epocales del ser y de la transmutación del ser en Acontecer expropiador (Ereignis), está el "emplazamiento» (Gestell). Éste es casi como una estación intermedia, ofrece un doble rostro, es - cabría deciruna cabeza de Jano. Pues puede ser todavía entendido como una continuación de la voluntad de querer y por ende como una acuñación extrema del ser de la metafísica. Más a la par es una forma anticipada del Ereignis mismo (...) cuyo desvelarse tiene que ser experienciado, no puede ser demostrado (...) Pero ¿qué es entonces esta experiencia? ¿Es la abdicación del pensar? De hecho, sin embargo, el pensar y el experienciar no pueden ser contrapuestos a la manera de una alternativa. Lo acontecido en el seminario sigue siendo el intento de una preparación del pensar y, por ende, del experienciar. Pero esta preparación acontece ya pensando, por cuanto el experienciar no es nada místico, ningún acto de iluminación, sino la entrada o alojamiento en la morada del Acontecer expropiador. Así el desvelarse en el Acontecer expropiador

Nótese como "de un plumazo", decimos en castellano, se ha referido la ironía de Heidegger al Aristóteles de Hegel y al Aristoteles de Husserh ambos platonizados y no suficientemente capaces de acceder al Aristóteles originariamente griego que se abre cuando la enérgeia se piensa desde los presocráticos y no en relación a la potencia, sino a la acción no-cinética. La acción del ser, la acción de la verdad. Ésta es la verdadera urdimbre del Ereignis ontológico. Y también dice Heidegger en relación a Aristóteles esta vez en el ensayo: Überwindung der Metaphysik, publicado en 1954, y concretamente sobre la incapacidad de la tradición de la Metafísica occidental para recibir la enérgeia aristotélica violentamente transformada en actualitas: "Lo característico de la Metafísica es que en ella de un modo general y sin excepción de la existencia, si es que se trata de ella, se trata sólo de un modo breve y como algo evidente, y de lo que no hace falta hablar (por ejemplo la pobre explicación del postulado de realidad que se encuentra en la Crítica de la Razón Pura de Kant). La única excepción la constituye Aristóteles, que piensa a fondo la enérgeia, sin que nunca en el futuro este pensamiento haya podido convertirse en algo esencial en su originariedad. La trasmodelación de la enérgeia en actualitas y realidad, ha sepultado todo lo que aprecia en la enérgeia. La conexión entre ousia y enérgeia se obscurece. Hegel es el primero que vuelve a pensar a fondo la existencia, pero en su Logica. Schelling la piensa en la diferenciación entre fundamento y existencia, una diferenciación, sin embargo, que está enraizada en la subjetividad. M. Heidegger: Conferencias y artículos, op. cit., p. 68. 
sigue siendo ciertamente algo que ha menester de ser experienciado, mas, como tal, algo que precisamente y por de pronto está necesariamente vinculado con el despertar desde y para el olvido del ser. Sigue siendo, por tanto y por de pronto, un acontecer que puede y riene que ser señalado (...), esto es: dar señales que deban posibilitar la dirección de la entrada en el paraje del Acontecer expropiador. Pasa por un trance análogo al de la poesía de Hölderlin, que hace un siglo no estaba ahí - y sin embargo estaba- (...).

De la finitud del ser se habló primero en el libro sobre Kant. La finitud aludida durante el seminario del Acontecer expropiador y el Geviert (cuadratura del cielo y la tierra, los mortales y los inmortales) (...) se diferencia empero de aquélla en que ya no es pensada en referencia a la infinitud, sino como finitud en sí misma: finitud, fin, límite, lo propio - estar oculto en lo propio-. En esta dirección, esto es: desde el Acontecer expropiador mismo, es pensada la nueva noción de finitud ${ }^{104}$.

Así prosigue el Andenken (rememorar) de Heidegger el Eterno Retorno de Nietzsche, dando lugar al giro ontológico-estético de la hermenéutica como giro topológico de la misma, es decir: dando lugar al giro hacia otro espacio-tiempo del lenguaje al que se accede por la senda de lo que hemos llamado en el escrito antes mencionado ${ }^{105}$ "la estructura dialógica del olvido», pues es éste, en último término, la léthe oculta de la alétheia, en sincronía con ella, lo que se desvela ahora como misterio irreductible, destituyendo la reducción de la presencia-ausencia al mero presente y la paralela reducción de ser a ente que caracterizan el cierre metafísico de la diferencia ontológica. La Diferencia ahora otra vez abierta, en el repliegue oculto del límite del Acontecer (expropiador). Entramos con Heidegger en otra filosofía de la historia: la hermenéutica ${ }^{106}$.

${ }^{104}$ M. Heidegger: Protocolo de un Seminario sobre Tiempo y Ser. op. cit., p. 74. Nuestra traducción.

105 "La diferencia dislocada: Nietzsche, Heidegger y los griegos», cap. IV de El retorno de lo divino..., op. cit.

${ }^{106}$ Sinceramente pensamos, tras veinte años de fatigar los textos de Heidegger —como diría Jorge Luis Borges- que quien pretenda comprender a Heidegger al margen de los griegos se corta de antemano las alas antes de haber iniciado siquiera un vuelo que esta vez no termina como el de ĺcaro en el incendio del sol, pues ha de disponerse a una largo viaje a través de la noche hasta llegar al límite del alba. Hay un cuadro de Gustavo Torner, extraordinario, que sobre el lienzo plano y liso hasta la mitad horizontal inferior, cubierto de rojo y negro, ha inscrito las palabras de Parménides: «el día de la noche el día separaba», de manera que jel espacio enfáticamente plano 


\section{II.1.c. Gadamer y los presocráticos.}

Será, sin embargo, H.-G. Gadamer quien nos permita comprenderlo mejor, contribuyendo decisivamente a impedir que la alteración heideggeriana del lenguaje de la tradición metafísica para preparar otra filosofía de la historia, sea tachada de gnosis mitologizante o poetizante por parte de los conservadoresmodernos que rechazan entenderlo por no poder inscribirlo en ninguna de las vías previas del lenguaje convencional. ¿Y cómo habrían de conseguirlo cuando el esfuerzo original y excelente de Heidegger -insiste Gadamer- es precisamente el de ir abriendo, a través de la experiencia originaria del pensar-decir griego (y lo no-dicho y no-pensado que en ello se alberga) las vías de un futuro desconocido e imprevisible? ${ }^{107}$ Por eso viene Gadamer a continuarlo, por las sendas inéditas del otro inicio de Occidente, sintiéndose llamado a atestiguar la radical coherencia y pertinencia del pensar de su maestro. En primer lugar, y con la autoridad de un filólogo doctorado en Clásicas - como Nietzsche-, profundo conocedor de la lengua y la filosofía griegas, mostrando la coherencia sin par de las interpretaciones presocráticas heideggerianas y el rigor racional de su principal descubrimiento: el de la noesis de la alétheia como unidad dialógica o mismidad-

del cuadro se curva!, haciendo visible lo invisible: su espalda, como si la pared de cuadro se horadara, mientras no se puede interrumpir el continuo y siguen sonando-girando las palabras en el silencio interior del lenguaje, sin que ya sean visibles ni las pronuncie nadie. "De la noche separaba el día de la noche separaba el día..... Platón dirfa que suenan en la memoria de lo verdadero, en la anámnesis: Lo contrario de f́caro. No se puede entender a Heidegger, de verdad, sin los griegos, por lo mismo que, para nosotros, resulta muy difícil ya entender a los griegos sin el gran filósofo Martín Heidegger.

${ }^{107}$ Cfr. H.-G.Gadamer: Heideggers Wege. Trad. Inglesa de John W. Stanley: Heidegger's ways. «Prefacen: pp. vii-viii. State University of New York Press, 1994. Véase también Mis años de aprendizaje. Trad. Rafael Fernández. Ed. Herder, Barcelona, 1996, pp. 248-258. Oigamos lo que dice Gadamer, en el último pasaje referido, sobre el Heidegger de la ontología estética que se inicia con El origen de la obra de arte de 1936: "Era la lucha empecinada por un lenguaje filosófico, que más allá de Hegel y también de Nietzsche, fuera capaz de repetir, de traer de nuevo a nuestra presencia el más antiguo comienzo del pensamiento griego. Recuerdo una ocasión en que Heidegger en su cabaña de la Selva Negra, durante los años de la guerra, empezó a leerme un ensayo sobre Nietzsche en el que estaba por entonces trabajando. De pronto se interrumpió, pegó un puñetazo sobre la mesa que hizo saltar las tazas de té y exclamó desesperado e irritado: ${ }_{i} E s$ como si estuviera escrito en chino!n. Esto era la penuria del lenguaje como solo la puede experimentar quien verdaderamente tiene algo que decir. Heidegger necesitaba todas sus fuerzas para soportar esa penuria del lenguaje y no dejarse disuadir por ninguno de los ofrecimientos de la tradicional metafísica ontoteológica y su aparato conceptual" (op. cit., p. 256). 
diferencial entre Parménides y Heráclito, en que se basa toda la producción del «Segundo Heidegger» o "Último Heidegger». El Heidegger posterior a Ser y Tiempo y a la Köhre, que a Gadamer, de acuerdo con sus expresas declaraciones, más le interesa proseguir: el Heidegger presocrático, que tanto había aprendido de la hermenéutica de Aristóteles ${ }^{108}$.

Tal será en términos generales la invalorable contribución de Gadamer a la referencia presocrática en el sentido preciso que nosotros hemos ido desgranando: el de abrir otra historicidad-epocalidad menos violenta, como reproposición de una cultura trágica donde el arte y la filosofía estén legitimados: la era hermenéutica. Y, para ser más precisos, haciendo mención explícita a la original aportación de Gadamer en este contexto, se tratará, por su parte, de mostrar ahora cuál es la diferencia de Heráclito respecto de Parménides (una vez sentada su mismidad). Y, en paralelo, de defender los derechos de la diferencia de Platón ${ }^{109}$ - para expresarlo en el estilo agonístico del pólemos dialéctico- respecto de Aristóteles. Pues eso toca en dialógica, una vez localizado el núcleo de su profunda convergencia-continuidad en torno a la filosofía del bien ontológico. Así pues, de acuerdo con las reglas del juego que rigen y ritman el proceso recíproco de unitaria confrontación dialógica, hay que darle ahora la palabra a Platón. Hay que volver a darle la palabra a Platón que, por así decirlo, no ha vuelto a abrir la boca desde Nietzsche. El cruce dialéctico de la hermenéutica griega de Gadamer da lugar, de este modo, para empezar, a una insólita deconstrucción de varios tópicos espesos reinantes en esta materia, y entre otros hallazgos, viene a mostrar algo no poco sorprendente: la honda proximidad entre Heráclito y Platón. La cual responde en paralelo a cómo Heidegger había mostrado ya las claves de proximidad entre Parménides, Aristóteles y él mismo, el propio Heidegger. Pero puestas así las cosas es ahora cuando nos espera lo más asombroso de este juego que altera la memoria viniendo a poner patas arriba muchas tópicas convicciones. Pues, en efecto, sólo de la mano de Heráclito-Platón podremos advertir cómo Gadamer se adentra en una relectura inédita de Nietzsche que nos desvelará, a

108 No pueden dejar de leerse en este punto tres textos de Gadamer contenidos en el Heideggers Wege, además del "Prefacio» ya mencionado. A saber: "The greeks", op. cit., pp. 139-153; «Plato", ibíd., pp. 81-95; y "The History of Philosophy», Ibíd., pp. 153-167.

${ }^{109}$ Gadamer ha llamado a menudo la atención sobre cómo Heidegger ponderaba sus investigaciones sobre Platón y le preguntaba con notable interés por el curso de las mismas. Cfr., por ejemplo, J. Grondin: H.-G.Gadamer: Una Biografia. Ed. Herder, Barcelona, 1999; caps. VII: «Refugio entre los griegos" y VIII: "Insegura libertad antes de la tormenta" (pp. 153- 204, especialmente pp. 187-190). 
la vez que a un Gadamer trágico habitualmente desconocido, lo más fascinante: el secreto mejor guardado de la Hermenéutica actual como filosofía y como epocalidad occidental. Filosofía y epocalidad hermenéuticas donde se cumple no sólo ya el preparar un pensamiento por la paz, sino la gran reconciliación del perdón que sí está en condiciones de interrumpir el espíritu de venganza y el resentimiento contra la vida característicos, hasta aquí, de la enfermedad de la historia. Se trata de un secreto de Heráclito que Gadamer hace suyo por entero y que permite aproximarse a la experiencia quizá más originaria del lenguaje y de la racionalidad hermenéutica gadameriana, volviéndose al inicio de la sabiduría occidental.

\section{II.2.a. Textos presocráticos de Gadamer.}

Nosotros nos acercaremos a ese misterio a través del hilo conductor que H.-G. Gadamer mismo nos propone destacadamente estudiar: la cuestión del bien ontológico, con la que se abre, desde su punto de vista, la puerta de la memoria de los filósofos presocráticos, por medio de esa polémica de capital importancia para la filosofía, que a todos los occidentales concierne desde que discutimos con Platón y Aristóteles ${ }^{110}$.

De entre todos los textos presocráticos de Gadamer que elencamos en la bibliografía seleccionada al final de este estudio (a favor de que el lector/a se haga una idea de la amplitud de la investigación presocrática gadameriana), nosotros nos centraremos principalmente en la lectura de cuatro de sus obras, que son las siguientes, y se ordenan de acuerdo con el siguiente itinerario filosófico que nos parece el mejor para leer al último Gadamer:

I. El inicio de la filosofia occidental donde Gadamer explora lo que vamos a llamar la "Ontología Dialógica» como experiencia originaria de la dialogicidad del ser-lenguaje, desde la perspectiva de la Mismidad de la Diferencia. Se trata, en consiguiente, de Parménides, ofreciendo un rico y pormenorizado análisis de las secciones del Poema del Eléata que conservamos. Gadamer dedica el estudio a Heidegger y viene a corroborar en lo esencial las tesis heideggeriano-parmení-

${ }^{110}$ El último volumen que, cuando escribimos estas páginas, vuelve a ocuparse de la discusión entre Platón y Aristóteles es la compilación de Mauricio Migliori: Gigantomachia. Convergenze e divergente tra Platone e Aristotele. Ed. Morcelliana, Brescia, 2002. 
deas relativas a la apertura de la "Diferencia Ontológica» como lugar de la verdad del ser-pensar. El estudio de Gadamer se estructura en dos partes: «Parménides y las dóxai brotôn» y "Parménides y el ser». Con él culmina la investigación acometida por los textos, relativamente independientes entre sí, contenidos en este libro del último Gadamer, donde se reúnen una serie de lecciones dictadas por el maestro originariamente en italiano (en el Istituto Italiano per gli Studi Filosofici de Nápoles), en 1988. Todos los artículos que configuran El inicio de la filosofia... revisten una importancia innegable para el conocimiento de la hermenéutica presocrática de Gadamer, pero son en especial los estudios parmenídeos los que destacan como una gema, pequeña y brillante, en medio de este volumen y de toda la obra gadameriana ${ }^{111}$.

II. El inicio de la sabiduría occidental. Lo mismo se puede decir de esta otra joya gadameriana templada al fuego de sus "Estudios heraclíteos». En ellos se aborda la otra cara del símbolo constituyente de la ontología hermenéutica del diálogo. A saber: la Ontología Dialogal de la experiencia originaria del ser-lenguaje, vista ahora con Heráclito, desde la Diferencia de la Mismidad. Y, volvemos a decirlo, si la rigurosa hermenéutica gadameriana de Parménides corrobora a Heidegger y afianza también (como Heidegger descubriera) que ambos, Parménides y Heráclito, han establecido el mismo ámbito ontológico del arché (como límite y unidad indivisible intensiva, a la vez que como Diferencia Ontológica entre el ámbito del arché y el de la dóxa: el de las opiniones, creencias o fenómenos), es con la investigación de los aforismos de Heráclito con lo que Gadamer ofrece su aportación más original a la hermenéutica presocrática. Y ello no sólo en el sentido de que su conocedora y profunda lectura de los aforismos del Efesio nos permita acceder a una mejor comprensión de su sabiduría y de la diferencia entre ésta y la de Parménides, sino también porque el Heráclito de Gadamer nos entrega inesperadamente la verdad oculta del alma trágica del propio Gadamer. Y con ello la clave oculta de la dialéctica hermenéutica como filosofia del espiritu: como teología filosófica inmanente y como filosofia de la historia alternativas, respecto de la teodicea y la metafísica de la historia ilustrada. Es por eso por lo que la importancia de estos textos, que son como una estrella roja y azul, nacida de las entrañas de la tierra celeste, apenas puede ponderarse.

111 H.-G. Gadamer: El inicio de la filosofia occidental. Lecciones transcritas desde grabaciones orales y compiladas por Vittorio de Cesare. Original italiano: Linizio della filosofia occidentale. Ed. Istituto italiano per gli Studi Filosofici. Edit. Angelo Guerini, 1993. Trad. Castellana de Ramón Díez y M. Carmen Blanco. Ed. Paidós, 1. ${ }^{\circ}$ ed., Barcelona, 1995. 
Señalan, en efecto, los Estudios heracliteos de H.-G. Gadamer, el nacimiento de la racionalidad hermenéutica postmoderna que se orienta hacia otro inicio de Occidente, "repitiendo" de otra manera el inicio de la sabiduría occidental originaria $^{112}$.

De los escritos reunidos en El inicio de la sabiduría occidental, ya en cuya introducción ¡fechada en 1999! (tres años antes de su muerte) nos reenvía el último Gadamer explícitamente a los Estudios parmenídeos de las lecciones de Nápoles del 1988, puede decirse lo mismo que en el caso anterior: que todos ellos tienen importancia para la comprensión del papel esencial-constituyente que juega la filosofla griega en la hermenéutica de Gadamer. Pero que son los Estudios heraclíteos — divididos en dos partes: «La transmisión de Heráclito" (que fue impresa en 1974) y el texto de la conferencia "Estudios heraclíteos» leída por primera vez en la Academia de Ciencias de Heidelberg el 11 de febrero de 1984- los que han de destacarse con el énfasis que estamos razonando, no sólo dentro de esta colección editorial que los alberga, sino en el conjunto de toda la obra y el legado filosófico de Gadamer ${ }^{113}$.

También merece destacarse en esta preciosa colección el escrito de 1978 "La filosofía griega y el pensamiento moderno", donde Gadamer resume con particular elegancia y sencillez los motivos racionales por los cuales la hermenéutica postmoderna se propone como una reproposición de la filosofía griega en orden a de-limitar críticamente la modernidad irrenunciable (pero de-limitada y transformada por Grecia) del actual futuro de Occidente ${ }^{114}$.

112 H.-G.Gadamer: Der Anfang des Wissens. Philip Reclamm Stutgart, 1999. Trad. Antonio Gómez Ramos. Ed. Paidós, Barcelona, 2001.

113 Sobre la procedencia de todos los textos que se contienen en el libro El inicio de la sabiduría occidental véase la nota informativa correspondiente en op. cit., pp. 149-150. En ella se advierte debidamente que todos estos escritos han sido escrupulosamente revisados por Gadamer mismo, para la edición alemana, a sus 99 ańos de edad.

114 Ibíd., pp. 125-132. Es de lamentar que en este caso la traducción castellana haya resultado tan apresurada. Afortunadamente contamos con otro escrito de Gadamer más amplio que se refiere exactamente al mismo pensamiento y ha tenido la suerte de recibir una traducción más esmerada. Se trata del texto: «El significado actual de la filosofla griegaw: Der Gegenwartsbedeutung der griechischen Philosophie, aparecido en la revista «Pratika tis akadimias Athinon», 1972, $\mathbf{n}^{\circ} 47$, pp. 243-261. Trad. castellana de Ana Agud y Rafael Agapito, en el volumen de H.-G. Gadamer Anotaciones hermenéuticas. Ed. Trotta, Madrid, 2002, pp. 125-143. La correspondiente edición original ofrece el último libro de Gadamer publicado en vida del filósofo y ha sido aún brevísimamente introducido por él mismo a los 100 años de edad: Hermeneutische Entwürfe. Ed. J.C.B. Mohr, Tübingen, 2000. 
III. El estado oculto de la salud. Colección de entre cuyos escritos recomendamos la lectura atenta de dos de ellos para no perder nuestro hilo conductor, que es el de la experiencia de la ontología dialógica originaria (del ser-lenguaje) que Gadamer realiza a través de la hermenéutica de Parménides y de Heráclito. Se trata de "Experiencia de la muerte" (1983) y "Vida y alma" (1993). Ambos textos, leídos conjuntamente, corroboran de un modo asombrosamente sencillo y muy comunicativo la hermenéutica del Gadamer presocrático-trágico cuyo semblante estamos estudiando y defendiendo ${ }^{115}$.

IV. Mito y Razón. De entre cuyos escritos merece ser destacado otro de los textos de insólita lucidez correspondientes al Gadamer de la década de los 90 , vuelto cada vez más, como en el caso de su maestro Heidegger, a los primeros filósofos griegos, para perfilar con nitidez la orientación postmoderna de su legado hermenéutico. Cada vez más cercano a la fuente y buscando ya remontarse a ella, desde la proximidad al mar que es el morir. Se trata del imprescindible escrito "Acerca de la fenomenología del ritual y del lenguaje» (1992) (cuya hermosa traducción castellana debemos en este caso a la sensibilidad del profesor José Francisco Zúñiga $\left.{ }^{116}\right)$. En este caso Gadamer, una vez más preocupado por la esencia ontológica del lenguaje, se remonta a Heráclito, pensándolo e interpretándolo desde la comprensión hermenéutica del lenguaje propia de Aristóteles, que Gadamer aquí hace ya enteramente suya con una salvedad: que no comparte la crítica de Aristóteles a Platón por considerar que la cuestión esencial que interesa a Platón no es la de los archaí o Primeros Principios ontológicos, sino la más propia de un Platón literato y retórico, igualmente preocupado (como Gadamer aquí) por la esencia-proveniencia del lenguaje-lógos. Cuestión esencial a la que el Platón educador, visto como una especie de Shakespeare griego, como un dramaturgo que además fuera filósofo, habría contestado de forma activa-lingüística creando el diá-logos como forma educadora y virtuosa del lenguaje en que se da la participación filosófica en la investigación del bien.

La convergencia en este texto entre Aristóteles-Gadamer y Heráclito-Parménides se centra en el análisis de las acciones simbólicas y desemboca en la reproposición de la noética como racionalidad espiritual de lo divino inmanente que le es posible al hombre. Explora por ello Gadamer aquí la conexión entre muer-

${ }^{115}$ H.-G. Gadamer: Über die Verborgenheit der Gesundheit. Shurkamp Verlag, Frankfurt am Main, 1993. Trad. Nélida Machain: El estado oculto de la salud. Ed. Gedisa, Barcelona, 2001.

${ }^{116}$ H.-G. Gadamer: Mythos und Vernunft. Ed. J.C.B. Mohr (Paul Siebek), Tübinga, 1993. Trad. J.F. Zúńiga: Mito y razón. Ed. Paidós, Barcelona, 1997. 
te-resurrección inmanente y lenguaje noético, entendiendo que en la experiencia temporal común e inseparable de la muerte-vida reside la esencia del lenguaje: de la vigilia y apertura para lo que es «que presta al sentimiento griego del ser la mayor y perfecta vigilia, claridad y ligereza de la existencia. De esta suerte Aristóteles ha alabado el ideal teorético de la vida, precisamente como elevarse por encima de la muerte en la medida en que esto es posible para el hombre ${ }^{117}$ ". A cuya esencia mortal pertenece no sólo la claridad sino también el oscurecimiento tal y como expresa perfectamente Heráclito en el Fragmento 26 que Gadamer traduce así:

"El hombre, en la noche silenciosa, enciende la luz para si mismo" $"$ ".

V. Como complemento del escrito anterior, no puede dejar de leerse el texto "Palabra e imagen ("Tan verdadero, tan siendo)" ${ }^{119}$, que en realidad ofrece una clave de comprensión indispensable para toda la hermenéutica gadameriana en su conjunto, por poner en obra un discurso filosófico esencialmente determinado por la ontología de la acción comunicativa (enérgeia kai entelécheia) y la verdad modal (alétheia) —a la que hoy llamaríamos «estética»- Así pues, partiendo de la distinción esencial entre movimiento (kinesis) y acción (enérgeia) que inaugura Aristóteles con su filosofía modal en el libro IX de los Metafisicos, para poder pensar la verdad ontológica de Parménides y Heráclito, repropone Gadamer en este texto una ontología estética que descubre la urdimbre reactualizada por Heidegger en El origen de la obra de arte. Gadamer explicita en este escrito invalorable, también la conexión necesaria entre la filosofía del eterno retorno y la doctrina de la enérgeia de Aristóteles, acuñando la expresión excelente "devenir al sern, para indicar que el ser surge del devenir. Lo cual implica acometer el giro noético que abre las puertas del ámbito de la sincronía espiritual: «a la vez». El ámbito propio de la hermenéutica que es el que se nos abre cuando comprendemos que el movimiento se subordina a la acción extática del sentido. O sea: cuando comprendemos algo correctamente de tal modo que emerge en el desocultamiento ese mejor modo de ser que está guardado en la obra misma. Para lo

117 H.-G. Gadamer: op. cit., p. 142. Véase también de Gadamer: "Über das Göttliche im frühen Denken der Griechen" [Acerca de lo divino en el pensamiento primero de los griegos], en Gesammelte Werke, vol. 6, pp. 154-170. Y también el texto «Europa y la oikouméne» (1993), en El giro hermentutico. Trad. Arturo Parada. Ed. Cátedra, Madrid, 1998, pp. 219-238.

118 H.-G.Gadamer: "Fenomenología del ritual y del lenguaje», op. cit., p. 133.

119 Contenido en la colección Estética y hermenéutica, op. cit., pp. 279-307. 
cual hay que buscar el punto desde el cual emerge mejor. La secreta mismidad del crear y el recibir, que no es sino la unidad modal intensiva presocrática, permite comprender así, para Gadamer, por qué la ejecución es la interpretaciónrecepción, propiamente poética, que se distingue netamente de la reproducción tecnológica en cuanto a la diferencia de lo nuevo. Pues esta diferencia, que se multiplica sin dividirse en cada repetición-interpretación de la obra de arte, produciendo su eternidad como vigencia siempre distinta, sólo da lugar al desgaste del paso del tiempo en el caso de los objetos técnicos o los utensilios que se vuelven inservibles con el uso. En ellos la reproducción no alcanza la singularidad de la diferencia, sino sólo la abstracción de la semejanza que es propia de los conceptos realizados a los que llamamos «objetos». De ahí que el arte se sitúe tan cerca del modo de ser de la vida-muerte de la physis y las acciones de la pólis, como nunca pueden estarlo los procesos cinéticos de técnica alguna.

En este escrito habla el Gadamer aristotélico-presocrático, con la clara y profunda voz de la hermenéutica filosófica postmoderna: se trata de subordinar el movimiento al eterno retorno de lo mismo diferencial, y ni siquiera de imprimir el ser en los caracteres del devenir - por si cupiera en Nietzsche aún la ambigüedad metafísica que denuncia Heidegger - sino de acompañar o cuidar el devenir del ser, cada vez, dejando serena o prudentemente que la creatividad de la libertad del hombre descanse en la esencia de la verdad que deja activamente emerger lo oculto.

VI. Por último no debe olvidarse que para estudiar no sólo al Gadamer presocrático (y la hermenéutica del filósofo centrada en la Ontología Dialógica originaria del lenguaje del ser, que debemos a Parménides y Heráclito), sino también al Gadamer erudito especialista en los Presocráticos, ha de tenerse muy en cuenta el escrito magistral de Gadamer I Presocratici, aparecido originalmente en italiano. Pues resulta de particular interés en esta materia atender la enseñanza de Gadamer en tanto que sabio historiográfico versado en el conocimiento documental-hermenéutico de las recepciones e interpretaciones históricas de los filósofos presocráticos. Así lo hemos hecho nosotros en la primera parte del presente estudio, procediendo a analizar la singular contribución de Gadamer con $I$ Presocratici a la obra monumental Cuestioni di Storiografia Filosofica (la storia della filosofia atraverso $i$ suoi interpreti) ${ }^{120}$. Así mismo conviene estudiar, en para-

${ }^{120}$ Op. cit. supra: véase la sección "Hermenéutica Primera» de este estudio. Ed. Vittorio Mathieu. Brescia, la Scuola, 1975. La lectio de Gadamer: I Presocratici, en pp. 21-120. 
lelo, el tratamiento gadameriano de la cuestión del bien ontológico en Platón y Aristóteles, para no olvidar nunca que, de acuerdo con Gadamer, es historiográficamente en la polémica entre ambos filósofos, donde nace hermenéuticamente la filosofía de los presocráticos. Y, en tal orden de consideración, no se debe prescindir tampoco del escrito Die Idee des Guten zwischen Plato und Aristoteles. Por esta vía y esta cuestión la emprenderemos ahora mismo nosotros.

El catálogo editorial completo de los artículos y obras de H.-G. Gadamer sobre los filósofos presocráticos puede verse al final de esta investigación. Nuestra pregunta central no es de continuo sino ésta, que pensamos se debe reproponer en cada una de las lecturas recomendas por el itinerario señalado: ¿qué nos descubren los textos presocráticos de Gadamer?

\section{II.2.b. La vía de Gadamer: el bien ontológico. Del conflicto entre Aristóte- les y Platón a los presocráticos.}

Estudiar a los presocráticos siguiendo las indicaciones hermenéuticas de Gadamer, supone abrirse al asombroso pensamiento de los primeros filósofos, llegado hasta nosotros a partir de las referencias e interpretaciones de Platón, de Aristóteles, y de las tradiciones hermenéuticas que de ellos arrancan, sobre todo en el caso de este último. Pues, como es sabido, son Teofrasto y Simplicio nuestros principales informadores y suministradores de textos presocráticos, siguiendo las lecciones de Aristóteles y concretamente dos libros, en especial, del Estagirita: el primer lógos de la colección de los Físicos y el primer lógos de la colección de los denominados por peripatéticos posteriores libros Metafisicos de Aristóteles, a los que el filósofo llamó en rigor lógoi de Próte Philosophía: discursos, tratados o lecciones de Filosofía Primera como ontología y teología racional ${ }^{121}$.

Es decir: lógoi de ontología del lenguaje del ser (a partir de la revisión crítica de las opiniones e interpretaciones autorizadas y reconocidas por la tradición de la comunidad cultural: los Endoxa) y de teología racional del lenguaje en que se da lo divino (a partir del análisis crítico del propio lenguaje ontológico guiado por la búsqueda causal-condicional de los últimos límites constituyentes de ese mismo lenguaje). Lógoi de lo primero o de los primeros principios-seres, porque en ellos, en su modo de ser, confluyen el lenguaje ontológico y el teológico:

121 Véase Para leer la Metafisica de Aristóteles en el siglo XXI: «Cuestiones de Crítica filosófica e historiográfica antes del Aristóteles de W. Jaegern, op. cit., pp. 19-66. 
Filosofía Primera. Lógoi constitutivamente hermenéuticos y polémicos en que Aristóteles discute sin interrupción, particularmente con la dialéctica platónica y de los académicos. Pero no sólo, sino también con las restantes posiciones concurrentes de la tradición racional no mitológica: las otras posiciones argumentativas y las otras filosofias que se han pronunciado sobre lo Primero, sobre el arché y los archá, opinando sobre cuál sea el sentido primero que deba regir y orientar las decisiones, acciones e instituciones de la pólis y del hombre. Sobre cuál sea el sentido prioritario que debe orientar la decisión sobre lo que merece regir y gobernar. Y, en consecuencia, sobre lo que debe preferirse, tanto en el ámbito de la pólis como en el de la educación ciudadana, por ser, críticamente establecido merced a la discusión pública de lo mejor, lo que debe orientar. El criterio, el bien, lo que puede dar lugar a la comunidad política y la paideía, tanto de la ciudad virtuosa como de las diferencias individuales excelentes, por cuya intensificación y colaboración de conjunto se logra la riqueza cultural, política y espiritual, de la ciudad o comunidad misma.

Pues bien, en los dos casos: a) el lenguaje de la physis (en los lógoi Físicos de Filosofia Segunda), y b) el logos del ser y de lo divino (en los lógoi ontológicos y teológicos de Filosofia Primera), comenzará Aristóteles ${ }^{122}$ recordando las tesis de los filósofos presocráticos sobre el arché y los archai, en el sentido explicado. Siempre en orden a poder esclarecer, una vez examinado cuál sea el bien ontológico de la physis kai lógos y cuál su diferencia, lo mejor también en el campo de lo libre del êthos (conjunto de hábitos, carácter, morada) que pende de la determinación del hombre: el caso del bien político y del bien ético individual. Campo que compete especialmente a la educación de la excelencia o paideía del bien, a través de los saberes y las artes propios del ese lógos especial que se ha de decidir, investigar $\mathrm{y}$ adquirir.

Por todo lo cual en este caso - que es el de lo solamente humano, abierto a lo otro animado de la physis, y a lo ontológico de los principios del ser del lenguaje- la dialogicidad propia del lógos se da precisamente como educación o paideía de la memoria y de la cultura. Es decir: como revisión, mejora, transmisión, aprendizaje, adquisición, ejercicio y realización tendencial del lógos de la pólis. Pues éste se da y se transmite a través del hábito del aprendizaje de los diferentes saberes y de las diferentes artes y técnicas que filtran y comunican la expe-

${ }^{122}$ También lo hace en los éticos, en el De anima, en los biológicos, etc. Véase de Lambros Coloubaritsis: "Aristote: de la science à l'action", en Histoire de la Philosophie ancienne et medievale. Ed. Le Collage de Philosophie, Grasset, Paris, 1998, pp. 336-396. 
riencia comunitaria. $\mathrm{O}$ sea: mediante las distintas ciencias, sus lógicas de investigación, de crítica y de memoria, enseñanza y reserva; así como mediante las diversas artes liberales: las retóricas, las tecnológicas, las arquitectónicas, las artesanales y las poéticas. Todas ellas abiertas a crítica discusión pública a favor de permitir tanto la educación ciudadana comunitaria como el poder lograr, cada uno, la propia excelencia de su diferencia mejor y su vida más plena. A favor de enriquecer la vida de la pólis y la misma paideía de los contemporáneos y los posteriores. Esta es la estructuración básica de las investigaciones y la enseñanza de Aristóteles. Su intención general, por así decirlo. Con tal de no olvidar que, para el filosofo, tiene siempre primacía, en todos estos contextos, la investigación crítica viva sobre la ciencia potencial ya adquirida y disponible.

Physis kaì lógos kaì êthos. naturaleza viva $(y)$ lenguaje de la razón común $(y)$ eticidad, dependen así pues para Aristóteles en cuanto a su conjunción y articulación, exactamente igual que para Platón, de la cuestión ontológica del bien. Una vez entendido éste como criterio primero del lenguaje racional mismo. Lo cual equivale a decir que penden en cuanto a su coherencia y unificación, estos mismos ámbitos racionales y sus respectivos cuadros epistémicos, de la cuestión del bien ontológico, desde cuya perspectiva únicamente se han de poder trazar los límites y divisiones que distinguen tales racionalidades entre sí, a la vez que sus respectivas competencias y regímenes lingüísticos y, en una palabra: el mapa en relieve de la topología racional de los saberes y su jerarquía de conjunto, de cara a la paideía política.

Es, en todo caso, tarea del lenguaje crítico-ontológico investigar el bien como criterio, y la topología hegemónica de las racionalidades resultante. Tal es la principal tarea de la Dialéctica platónica y de la Filosofía Primera aristotélica. Objetivo que han de acometer, además, no de cualquier manera, sino de acuerdo con la discusión y el diálogo crítico que permiten que se muestre en el discurso mismo eso: lo primero, lo posibilitante del dialogar, el discutir, el refutar y el argumentar; el asumir o el declarar imposible, el preferir, el preguntar, el encomiar, etc. De modo que, en ese mismo sentido, depende de cómo se plantee la investigación ontológica el que pueda darse o mostrarse en el lenguaje eso posibilitante de la experiencia originaria. $\mathrm{O}$ sea: de la experiencia constituyente del pensar, entendida como experiencia del bien del lenguaje en todos sus registros mencionados y en su debida conjunción. La propia de la unidad-enlace como articulación diferencial entre la physis kaì lógos kaì êthos, posibilitada por la unidad-límite indivisible del bien. Y aún más concretamente: del modo de ser del bien o del uno, y de la comunidad y de cada uno. 
Desde la triple perspectiva de ontología, henología y modalidad, como instancias que se combinan entre sí, se indaga, pues, en Platón y en Aristóteles, la cuestión del arché o cuestión del principio, siempre en el marco del pluralismo de las Diferencias, que caracteriza por igual a ambos pensamientos:

A) Desde la Ontología de las determinaciones o diferencias que por ser primeras, no siendo causadas sino causas, han de ser no relativas sino a sí mismas, y al ser-bien que tienen en común porque es su mismo modo de ser.

B) Desde la Henología de lo uno y lo múltiple, o del límite indivisible, lo compuesto divisible y lo ilimitado (de lo mismo y lo otro, la identidad y la diferencia, lo relacional, lo relativo, lo reflexivo, lo sintético, lo recíproco y los términos simples de las referencias; lo condicional y condicionado, lo contrario, lo contradictorio, etc.)

C) Desde la Modalidad de lo potencial dinámico referencial y lo actual activo-expresivo: lo necesario, posible, probable, contingente, eterno, efímero, regular, casual, accidental, etc.

Una triple perspectiva de análisis lingüístico de rica, compleja y flexible combinatoria, que permite, tanto a Platón como a Aristóteles, registrar, diferenciar ámbitos e inteligir lo que se da en el lenguaje, atendiendo, en resumen a lo siguiente:

(1) El significado de las determinaciones inteligibles: los términos. (2) La sintaxis o estructura relacional de los mismos: los enlaces; y (3) La modalidad espacio-temporal de las frecuencias de ambos registros (siempre, la mayoría de las veces, alguna vez, en tal o tal ámbito de consideración topológico-lingüístico): los modos.

Ello, no se olvide, en orden a poder plantear la cuestión del bien ontológico como criterio, de cuya indagación, interna a la experiencia reflexiva del lenguaje dialogal, surgen precisamente todas las distinciones mencionadas, cuyo sentido, sin embargo, no puede establecerse, más que formalmente, en caso de faltar la experiencia originaria del pensar-lenguaje que permita comprender cuáles son las condiciones de posibilidad del dialogar que necesita buscar el ser-bien del lenguaje mismo en cada caso.

Es aquí sin duda donde entran en juego los presocráticos para Platón y Aristóteles, exigidos por la tensión que busca dar con la experiencia originaria del pensar del principio, del arché, en los primeros pensadores contra-dogmáticos 
que dialogan. Los primeros que se interrogan, discuten y se dejan interrogar a su vez, por la cuestión del bien, el límite, el uno y lo múltiple, lo mismo y lo otro, lo común y el criterio... desde dentro del lenguaje participable y comunicable de los ciudadanos libres y su comunidad racional dialogal: los primeros filósofos. Por eso para nosotros, en Occidente, están los presocráticos en el origen, en el doble y decisivo sentido apuntado: el del comienzo de nuestra memoria crítica y el del inicio de nuestro problema característico y distintivo: el problema del bien ontológico, que se busca cada vez como criterio primero de la experiencia del pensar racional comunitario. El pensar que dialoga y se pregunta por los principios constituyentes del diá-logos y por el arché mismo del ser del lenguaje, y de todos los sistemas de orden. $O$ dicho más sencillamente ya con otras palabras: el pensar que se interroga por el principio del bien y la excelencia del lógos. Para la filosofía, para la ciudad, para las artes, los saberes, los seres animados, etc, etc.

Cabría no obstante inquirir a partir de este punto lo siguiente: si todo esto comparten Platón y Aristóteles, ¿đe qué discuten tan apasionadamente, entonces?, y dicho en puridad, ¿qué es lo que le pasa a Aristóteles? ¿Por qué discute de ese modo tan fehaciente con su maestro Platón, a lo largo, en realidad, de todos los escritos del Corpus, haciendo que la dialogicidad polémica propia del filosofar entable con los Amigos de las Ideas una dialéctica crítica que atraviesa y estructura el Corpus de parte a parte?

Sólo en terreno presocrático puede hallarse la raíz del problema y orientarse la compleja respuesta con claridad si se atiende a la muy diferente relación que Platón y Aristóteles establecen, por ejemplo, con la matemática escatológica y la concepción de la política de los pitagóricos el primero, o con la investigación de las leyes de la physis inmanente y el modelo político panhelenista el segundo. Pero, siendo esto cierto, la verdad es que si los pitagóricos, los milesios y también los llamados "pluralistas" parecen otorgar sobrados motivos para localizar el mencionado disenso entre Platón y Aristóteles, las profundas razones de éste han de buscarse, sin duda, en el ámbito ya antes señalado: el de la diferente comprensión, entre uno y otro, de la experiencia originaria del bien por parte del pensar y del lenguaje racional.

En efecto, parecería, a primera vista, si seguimos a Aristóteles, por ejemplo en el libro $A$ de los Metafisicos, que Empédocles de Agrigento y Anaxágoras de Clazómenes habrían de estar con él, con Aristóteles, quien los integra y recombina en su filosofía de los principios, situándolos respectivamente en los tres niveles posibles del límite: el de lo indeterminado ilimitado, el de lo determinante 
limitante y el de lo determinado delimitado. Lo cual equivale a entender que estos tres ámbitos lingüísticos del ser son los siguientes:

A) El de los elementos (stoicheia) de Empédocles, como últimos principios materiales cualitativos de la materia ( hyle) indeterminada y potencial, abierta a múltiples combinatorias, finitas cada vez e infinitas en número. Es decir: los alfabetos.

B) El del criterio o nivel del noein del noûs, el pensar-ser simple de la mente o el espíritu, no mezclado, solamente (haplôs) él mismo, separado e incomposible (choristón), como plena unidad indivisible (hén), ya descubierto por Anaxágoras y Parménides, y retomado por Aristóteles para situarlo en el lugar del Bien ontológico de Platón: el ser plenamente diferencial que es principio de vida, unidad e inteligibilidad para todos los que, en ese mismo bien, para ellos común, participan. Bien ontológico que es, como último principio espiritual o último límite irremontable, la condición determinante de todas las mezclas o unidades compuestas. Es decir: el sentido actual de los lenguajes.

C) El de las síntesis y sintaxis de lo determinado (peperasménon). Las cuales, si y sólo si se trata del ámbito de la materia viva al que llamamos "physis», se instauran en Aristóteles únicamente por deseo de ser y de estar bien; por deseo de participar (philía-lógos) —otra vez Empédocles- en el modo de ser del bien-serlímite diferencial y unitario de cada una; viniendo a componerse y a des-componerse, en vista a (béneka) llegar a ser su mismo ser diferencial. En vista a ser plenamente lo mejor de lo posible que ya son potencialmente: su propia excelencia en el ser y vivir bien: su propio ser-vivir de modo excelente, y ello en la conjunción composible de lo plural determinado - kósmos - del sistema topológico, o sistema sintáctico abierto a la interacción de aquellos otros de los que se trate en cada caso. Es decir: los repertorios de los lenguajes de la memoria de la vida.

Por contraste, Demócrito de Abdera, el atomista, habría de estar con Platón, o mejor dicho con "el último Platón" - a pesar de cómo protestaría Platón indignado - dada la progresiva tendencia matematizante del fundador de la Academia a concebir los primeros principios desde la extensión de los predicados (como géneros-formas universales y como números pitagóricos). Es decir, por parte de Platón, desde un punto de vista no muy desemejante, entonces, al de los átomos ideales (inexperimentables) de Leucipo y Demócrito, como mínimo en cuanto al enfoque elemental cuantitativo de la dialéctica académica, tendente a detener 
su análisis divisorio de lo compuesto en las unidades extensas discretas de los géneros universales. Y después en el Uno como Género Supremo del que éstas se habrían de derivar o deducir por mediación de la Díada indefinida. Explicación esta de marcada tendencia lógico-abstracta - piensa Aristóteles- que, por parte del platonismo pitagorizante de los últimos diálogos de Platón demanda un fuerte componente tecnológico a la hora de explicar, indiferentemente, las síntesis de los seres vivos tanto como las mezclas mecánicas o artificiales de los objetos cósicos. Todas ellas tratadas como productos de la inteligencia agente del sujeto artífice de las combinatorias sintéticas, siguiendo modelos-objetos ideales de la imaginación racional productiva. Pues, en efecto, ya sea para el hombre prudente (el phrónimos) del Filebo, ya sea para el dios ingeniero (el Demiurgo del Timeo), ya sea para el legislador de Las leyes, o el maestro de los ágrapha dógmata, el criterio-bien-unidad de las mezclas y las sintaxis es, al parecer, para el último Platón y sus agentes, siempre el de otra síntesis llamada «suprasensible». Un paradigma suprasensible en el sentido de ser inteligible e imaginable - aunque no carente de materia abstracta y de extensión, como subrayará radicalmente Aristóteles- . Por lo que, en último término, el paradigma se asimilará a la idea misma de síntesis o concepto: armonía, estabilidad, orden o salud, justicia y proporción que nivela los contrarios, etc. Mientras que el criterio-bien triunfante será así la idea de krásis o armonía pitagórica, coherente con la concepción del ser como mundo-orden integrado y estable: Kósmos. Igual de adecuado a la idea de la justicia o dike socrática, enfocada desde el ángulo de lo legislado, ordenado o equilibrado: lo bello.

En todos los casos se tratará del paradigma de la buena mezcla que está en la mente - y la imaginación - del ingeniero genético o del legislador, cuyo cálculo ni puede ni debe prescindir de la materia abstracta de la imagen: sus dimensiones, su extensión y su movimiento lógico-discursivo. Un modelo antropológico y exterior (transcendente) que se imprime normativamente a la materia (o al cuerpo social), tratada como inerte y pasiva, cuando no como desordenada y reacia a la ley, como si nunca hubiera habido la physis viva y soberana: la vida inteligente de la naturaleza y de la pólis, la razón común, y el azar, descubiertos por los primeros filósofos como espontaneidad auto-legislada e inteligible, enlazada por el lógos del limite en tanto que ley ontológica indisponible y primera respecto de cualquier sujeto posible. Ley constituyente y límite limitante que no pueden confundirse con ningún sistema de orden ni ningún producto modélico. Pues se trata, diferencialmente, del ámbito transcendental ontológico (posibilitante y determinante) de las síntesis mismas. El ámbito que ofrece, además, 
la condición de posibilidad de la crítica de todo sistema de orden y, de la misma manera, impide confundir el pensar con lo pensado, y el modo de ser del bien con ninguna configuración moral o sistema de costumbres cultural ${ }^{123}$. Impide cualquier legislación de las costumbres que no se entienda positivamente como mera convención.

Pero precisamente contra todas las instrumentalizaciones doxáticas del límite-arché que son propias de las culturas de las costumbres de los hombres y se vierten en mitologías antropocéntricas - las cuales terminan por diseñar lo divino indisponible a imagen y semejanza del hombre-, se había levantado el nacimiento de la filosofía. Se había levantado ya el logos de la physis kaì pólis que habían descubierto, siguiendo el espíritu de la sabiduría de los límites de Delfos, los primeros filósofos: los presocráticos. Los milesios, Heráclito, Parménides, y los pluralistas. ¿Qué pasaba entonces con los pitagóricos, con Platón y con el movimiento atomista? ¿Una recaída en el mito? ¿Un sistema mixto de filosofía y mitología? ¿Es de la instrumentalización tecnocrática y antropológica del bien ontológico de lo que discute Aristóteles con el Platón pitagórico, en orden a preservar el platonismo originario del Bien y de las Diferencias?

Como cada vez se va reconociendo más, a pesar de los espesos prejuicios que sobre la filosofía de Aristóteles se han ido acumulando durante milenios, el vitalismo espiritual que preside la ontología lingüística de la acción en Aristóteles rechaza de raíz el materialismo abstracto o materialismo lógico. El materialismo extenso que es propio del anterior punto de vista. En efecto, si el pensamiento de Aristóteles se empeña tan concienzudamente en esta crítica, esforzándose hasta la raíz en denunciar de todos los modos posibles, y argumento por argumento, que tal posición resulta insensible al bien ontológico y a la virtud, es porque, para decirlo mejor, semejante posición, la del racionalismo conceptualista platónico, desenvuelve, en efecto, un mero punto de vista extenso, cuantitativo e indiferente de por sí. Desenvuelve un punto de vista refractario a las diferencias cualitativas e intensivas del ser de la vida y el lógos. Insensible a todos los lenguajes de la vida, porque, en último término, se trata de un instrumento, un órganon, y un método de medición, que

${ }^{123}$ Para todo lo anterior véase "Parménides entre Platón y Aristóteles. El conflicto de las razones de Occidente" (en El nacimiento de la filosofia en Grecia..., op. cit., pp. 41-146 y 238-367), donde se someten a crítica pormenorizada desde este mismo punto de vista: el de la prioridad de los lenguajes de la vida sobre los tecnológicos, todos los últimos diálogos de Platón, a partir del Parménides. O sea: El Sofista, Politico, Teéteto, Filebo, Timeo y Leyes. 
por sí mismo es ciego y sordo a las cuestiones del sentido del lenguaje del $\operatorname{ser}^{124}$.

Por eso parecerá a Aristóteles que el pitagorismo destruye en realidad al verdadero platonismo y escinde en dos no sólo a la Academia sino al propio Platón magistral al que se debe continuar, según el Estagirita, sólo por la vía ética del bien ontológico y la ontología ética del lógos de las diferencias. Lo que equivale a decir que han de tomarse las Ideas o primeros principios como acciones excelentes que se dan, se comunican y se transmiten en los lenguajes vivos de la pólis y de la physis. $\mathrm{O}$ sea: exactamente igual que lo comprenderá Gadamer, siguiendo en esto a su maestro Heidegger y devolviendo desde Aristóteles la palabra a Platón, para subrayar de modo convincente y difícilmente discutible, lo que sí comparten ambos: el platonismo de ambos filósofos partícipes en lo mismo. Es decir: en la ontología ética o práctica del ser-bien de los lógoi y del lógos que responde a la apelación socrática de la virtud (areté), la unidad de la virtud, y su comunicabilidad racional en orden a la paideía política de la comunidad ciudadana.

El platonismo del Bien ontológico que, según ha explorado esta vez Heidegger, siguiendo a Aristóteles a través de las nociones prácticas de enérgeia kaì alétheia kaì entelécheia (acción y verdad ontológicas comunicativas) redescubre el vínculo libre - no antropomórfico - entre la pólis y la physis, haciéndolo remontarse a la copertenencia recíproca y diferencial entre pensar-lenguaje y ser, que se da en el acontecer del espacio tiempo tetradimensional, como ya vimos. Tal es la ontología del Ereignis con que el último Heidegger, en Tiempo y Ser, repliega a Aristóteles en los hexámetros del poema didáctico del Eléata: el poema consagrado al método de la verdad que conservamos proveniente de Parménides.

Pero no se puede ir tan deprisa, pues tales trazados, aun siendo indispensables y todavía poco reconocidos por parte de la tradición metafísica moderna dominante (como es lógico, pues ella es justamente la afectada por la crítica de Aristóteles al pitagorismo en su núcleo de ignorancia y abstracción constitutivas: el logiscismo del sujeto/objeto y sus estructuras de orden dominate), parecen venir demasiado pronto o resultar algo prematuros. En efecto, lejos de explicar o permitir comprender en profundidad la discusión entre Platón y Aristóteles que nos preocupaba, más bien suponen darla por sentada y zanjada, sin llegar a preguntarse por su raíz. Vienen a ofrecer, entonces, en cualquier caso, unas con-

${ }^{124}$ Véase en Para leer la Metafisica de Aristóteles en el siglo XXI, el libro segundo: «Discusión de la lectura ontoteológica. El olvido de la próte ousía natural en la metafísica de la escisión», op. cit., pp. 143-323. 
secuencias que han de remontarse a decisiones anteriores. Precisamente las decisiones que se nos brindan si abordamos la cuestión de otra manera, tal y como estamos apuntando. Justamente a la manera de Gadamer. A saber: suponiendo que es por causa de Heráclito y Parménides por lo que discuten esencialmente Platón y Aristóteles del único problema pertinente para todos ellos y para la ontología de lo primero: el del bien ontológico. Crucialmente el problema que les vincula entre sí y les vincula también esencialmente a los primeros filósofos, pues son ellos, Heráclito y Parménides, los que dan cuenta, junto con Anaximandro, de la experiencia originaria del pensar-lenguaje del ser. Del lógos y su unidad: su justicia y su bien. Los que dan cuenta de la experiencia ontológica originaria del lenguaje sin la cual deja de tener sentido y orientación, criterio y discernimiento el pensar, sumido en la ceguera, la locura, el extravio, la banalidad, la errancia, el abotargamiento, la arbitrariedad, o la desmesura. La brutalidad, la impotencia y la demencia. Pues sin la experiencia de su bien, su límite, su criterio y su unidad, ¿qué sería del lógos sino el incendio de la barbarie? Así, yendo a su raíz, plantean la cuestión con sus propias palabras las primeras ontologías del lenguaje del ser y del tiempo que ahora estamos rememorando: las de Anaximandro, Heráclito y Parménides en el alba del pensar occidental.

Y ésta es exactamente la fecunda perspectiva de la hermenéutica de Gadamer, siguiendo a Heidegger, su maestro, por la senda presocrática de Nietzsche y de Hölderlin: partir de cómo la experiencia originaria es ya siempre una memoria del futuro, una rememoración historiográfica que dialoga y discute sobre la interpretación del sentido de lo sido inicial, porque necesita orientarse en relación al bien. Desde ahí se propone Gadamer encontrar en la mismidad y diferencia entre Platón y Aristóteles las huellas del sentido unitario-divergente que permite comprender la profunda relación que hay entre Heráclito y Parménides. Pero siempre a través de la discusión que los posteriores les hacen entablar, debido a la distinta recepción y distinta interpretación de los primeros filósofos ontólogos que hacen Platón y Aristóteles, en base a la diversa experiencia originaria del principio y del inicio, de la que dan cuenta los textos transmitidos. Pues, en efecto, es en estos textos donde se registra y se da cuenta de la experiencia de una diferencia puesta en relación con una tensión extrema: la tensión que se da, en el alma del hombre, entre el pensar y el ser del lenguaje ${ }^{125}$.

125 Así lo enseña precisamente Gadamer en las lecciones reunidas en El inicio de la Filosofla occidental especialmente op. cit., pp. 13-79 (desde: "El sentido del inicio" hasta "Del alma al logos. El Teeteto y el Sofistas). También es ésta, por todo ello, la perspectiva de nuestro libro dedicado a 


\section{II.3. La hermenéutica como filosofia del eterno retorno: el devenir del ser}

Pero dejemos que sea Gadamer mismo quien nos lo cuente y oigamos lo que dice en El inicio de la sabiduria:

Los que le debemos al impulso de Heidegger el propio movimiento en el que intentamos pensar, sucumbimos a la misma fascinación que Heráclito irradia, y en el mismo sentido: las palabras de Heráclito, que requieren, como decía Sócrates, un buceador delio que las saque a la luz desde la obscura profundidad (Diógenes Laercio, II, 22), se hallan en una rara tensión con la reivindicación de sus palabras por los que llegaron después $^{126} .(\ldots)$

Se trata en Heráclito de proposiciones en forma de sentencias que ya en la Antigüedad eran célebres por su obscuridad y profundidad. Parece que Sócrates dijo que lo que él había entendido de ellas era excelente; y confiaba en que lo mucho que no había entendido también lo fuera. Hacía falta, desde luego, un buceador delio - un auténtico experto del buceo- para sacar a la luz el tesoro de las profundidades ${ }^{127}$. (...)

H.-G. Gadamer: El nacimiento de la Filosofia en Grecia. Viaje al Inicio de Occidente, así como del seminario audiovisual que registra siete sesiones de Didaskalia destinadas a posibilitar una primera iniciación oral y participativa en el filosofar, pensando con los escritos de los presocráticos. En ambos documentos se indaga la exigencia, el significado y sentido crítico que las más antiguas sabidurías racionales de Occidente tienen hoy para la experiencia del pensar occidental, su memoria del origen y su tarea. El Seminario oral también se acoge a ese hermoso título inventado por Giorgio Colli: "El Nacimiento de la Filosofia”, para conmemorar así aquél texto suyo del que brota la sin par exploración hermenéutica presocrática que debemos al gran filósofo italiano seguidor de Nietzsche, quien sin duda se cuenta, como Gadamer mismo (siempre continuando en lo esencial a Heidegger), en el linaje de los inmortales hijos de Heráclito. La obscura estirpe de buceadores que, según se decía de Heráclito ya en el Fedro de Platón, se adentra aún más hondo que los expertos delios en las profundas aguas del origen y el ser del alma. Tan hondo como sea posible, para lo $s$ mortales, para los hombres, aproximarse al enigma del fuego del pensar. Allí donde conducen las señales oraculares de Nietzsche el heraclíteo, inscritas en La filosofia en la época trágica de los griegos, en el Nacimiento de la Tragedia, y en la mística racional de un adivino, el mago persa del futuro posible para Europa y Occidente: Zaratustra: el maestro del eterno retorno.

${ }^{126}$ H.-G. Gadamer: Der Anfang des Wissen. Publicado por primera vez en alemán en 1999. Philippe Recalm, Stuttgart. Trad española de A. Gómez Ramos: El inicio de la sabiduría. Ed. Paidós, Barcelona, 2001, p. 18.

127 Ibíd., pp. 31-32. 
Tal es el argumento del pensamiento en el Fedón. Sócrates muestra a sus amigos cómo el principio de la vida y ese otro principio del "pensar" y de la "anámnesis», son uno y así mismo igual de inseparables que el devenir y el ser (Anaxágoras supo unir ambas cosas) ${ }^{128}$. (...)

El mismo conocimiento lo encarna el mito del Fedro del ascenso del alma y su caída. En este diálogo (...) Sócrates anticipa como una prueba: «iToda alma es inmortal!» $\mathrm{y}$ «Todo lo que es alma se ocupa de lo inanimado». ¡Véase cómo el alma se transforma de pronto en principio del automovimiento! La historia que luego se relata cuenta que este principio que gobierna todo el universo y gracias al cual mantiene su orden el cielo, tiene su lugar también en el alma del individuo y por cierto en la unidad de "amar" y «aprender». En la medida en que aprender es recuerdo de lo verdadero, «anámnesis", todo participa de lo verdadero. Está claro que éste es el gran conocimiento que Platón señala aquí y lo llama apódeixis (245c 4). El automovimiento es un verdadero milagro (...) de ello concluye Sócrates que aquello que es causa de semejante automovimiento tiene que existir siempre: el alma. Parece como si Platón cumpliera aquí una expectativa, que, como se dice en el Cármides (169a), sólo pudiera cumplir «un hombre muy sabio», a saber: mostrar que hay una dynamis que va hacia sí misma y no hacia otra cosa. Se mostraría entonces como el buceador delio que saca algo precioso a la luz desde las profundidades de Heráclito ${ }^{129}$.

Ya hay aquí varias tesis características de la hermenéutica presocrática gadameriana que suponen una honda y crítica reinterpretación tanto de nuestras asumpciones tópicas habituales como de la interpretación de los primeros filósofos que, a partir de Hegel y del lema de Nietzsche «invertir el platonismo!», ha desenvuelto Heidegger en orden a la auto-crítica de Occidente que hace luego suya la postmodernidad $^{130}$. Porque entonces, ¿y Platón? ¿No debería la hermenéutica

\footnotetext{
128 Ibíd., p. 32.

129 Ibíd., pp. 82-84.
}

${ }^{130}$ La crítica de la violenta tradición de la Historia de la metafísica occidental como tradición platónico-cristiana-moderna siempre en expansión hacia el más allá (metà tà physika) de todo límite, en que se lleva a cabo el progresivo nihilismo del olvido del ser y de la experiencia originaria del pensar del ser. La experiencia presocrática de la filosofía no-metafísica: la ontología inmanente, que se continúa en el Aristóteles griego, igualmente olvidado, tergiversado, dislocado y tapado por las transformaciones bíblicas de su apropiación monoteísta durante siglos (las judías, las ára- 
actual que ya remite de un modo esencial al Aristóteles desconocido y reencontrado en tantos y tan decisivos aspectos, devolverle también la palabra a Platón para dejarle aparecer por debajo de los sedimentos de estratos cristianos y seculariza$\operatorname{dos}^{131}$, que se prolongan hasta Hegel y se remontan, hacia atrás, cuando menos hasta Plotino y Filón de Alejandría? Gadamer así lo efectúa, prosiguiendo ahora, en cierto modo, a Schleiermacher y procediendo, por un lado, a restaurar la mismidad del platonismo de ambos - Aristóteles y Platón-, por la vía de mostrar cómo ambos deben ser leídos desde la ontologia ética del bien y la racionalidad práctico-teorética de la acción. Esta última cuidadosamente distinguida de la cien-

bes y las cristianas, las escolásticas y las ilustrado-secularizadas modernas: positivistas, evolucionistas, historicistas, neokantianas, hegelo-dialécticas, etc.). Precisamente hasta el jbasta ya! que con la hermenéutica se da la vuelta hacia lo otro no colonizable de los mismos textos filosóficos que constituyen nuestras tradiciones olvidadas, remontándose hasta la experiencia originaria del pensar y sus cruciales problemáticas desde el nacimiento de la filosoffa en Grecia. De ahí que la filosofía griega presocrática sea y esté en la esencia-proveniencia de la hermenéutica como filosofía actual y como koiné de la post-modernidad en curso, de un modo insólito: como investigación no del pasado sino del futuro que se abre ahora por el descubrimiento de nuestro pasado instituyente olvidado, pero no consumido, y de nuestro origen perdido, al parecer, ya a partir de Platón. Así lo muestra, al menos, con una amplitud y rigor asombroso la ignorada crítica de Aristóteles al platonismo pitagórico que en nuestros días ha sido redescubierta desde todos los ángulos: el de la hermenéutica filosófica contrametafísica abierta por Nietzsche y Heidegger lectores de Aristóteles y, trabajando por su cuenta en paralelo, pero dando lugar a resultados convergentes, el sin par redescubrimiento y renacimiento del Aristóteles griego por parte del criticismo académico universitario del siglo XX, incansable a partir de la crítica suscitada por el Aristoteles de Werner Jaeger, publicado en 1923. Cfr. Para leer la Metafisica de Aristoteles en el siglo XXI, op. cit., especialmente Libro I, p. 143 y Libro III, pp. 323-395. Véase también T. Oñate: «Aristotelian western criticism on the XXth Century: a radical change of paradigmm. Ed. SIPRIN (World Congress on Mola Sadra Islamic Philosophy Research Institut), Teherán, 1999.

${ }^{131}$ Tal es la aportación más original de Gadamer a la filosofla de los Presocráticos, según estamos viendo: redescubrir un Platón heraclíteo por debajo de las interpretaciones cristianas, vinculado estrechamente a un Heráclito originario radicalmente trágico, e igualmente recubierto por los sedimentos cristianos. Dice Gadamer:

"Yo creo que hay que sopesar esto muy en serio ¿ No debería ser posible quitar la capa de sedimentos cristianos y determinar las sentencias de Heráclito?", El inicio de la sabiduria, op. cit., p. 22. "Puede verse esto como un ejemplo clásico de lo que en el contexto de la hermenéutica he llamado "conciencia de la historia efectiva". Llevamos dentro una acuñación previa tan profundamente insertada que nos obstaculiza la comprensión de otras culturas y mundos históricos. Para llegar a una comprensión mejor hay que intentar hacerse consciente de la propia acuñación previa. Esto es bastante difícil en el caso de Heráclito, porque la influencia de finales de la Antigüedad y principios del cristianismo en la transmisión de Heráclito, sobre todo en los casos de Hipólito y Clemente, es la que ha producido en nosotros esta acunación previa, y, en esa medida nos extravia», ibíd., p. 61. 
cia moderna desde el centro mismo de la verdad ontológico-práctica hermenéutica ${ }^{132}$. Eso ya lo hemos visto de manera suficiente. Y, por otro lado -el que afecta a la diferencia o alteridad de ese lo mismo-, reentablando el diálogo entre Platón y Aristóteles, tal y como ahora toca, después de Heidegger. Volviendo a darle la palabra a Platón; pero no de cualquier manera, claro está, o no ficticiamente, fingiendo un diálogo condicionado e hipotecado de antemano, en el que Platón se viera obligado a responder a las objeciones de Aristóteles, sino haciendo, por tanto, que la discusión libre se remonte hacia atrás: hasta su proveniencia de Heráclito en Platón y de Parménides en Aristóteles. Así procede Gadamer: tensando los dos cabos de la aporía hasta el nudo de su raíz donde se toca un conflicto originario en la experiencia del lenguaje del bien ontológico. Una aporía que pone de manifiesto su carácter doble y dialéctico desde el principio.

Problemática esta que viene a desvelar también, de una sola vez, o al mismo tiempo, cuál es la radical naturaleza de eso que llamamos "dialogar" cuando no se trata del diálogo ya siempre fundado entre los hombres, sino del dialogar radical ontológico, situado en el ámbito del límite donde se enlazan y distinguen de modo extremo el ser y el pensar del lenguaje.

Tal es la densa matriz que abordan las interpretaciones presocráticas de Gadamer. Nosotros nos detendremos sólo, a modo de muestra de su hermenéutica del inicio, en el análisis de un problema siempre subrayado por Gadamer porque resulta esencial para ella: el del alma; su relación con el cuerpo y su relación con el espíritu.

Pero hay que ir con mucho cuidado, porque Gadamer es un lector y transmisor muy sutil. Volvamos a oírle interpretando el Fedón platónico en aquel pasaje de El inicio de la sabiduría que ya antes nos ocupaba. Aquél en que el filósofo alemán se refería al tesoro que el Sócrates de Platón recibía de la exploración de Heráclito, quien conteniendo la respiración al máximo era aún más capaz que los buceadores delios de adentrarse en una inmersión audaz por las aguas más profundas, hasta lograr sacar de ellas a la luz un extraño y precioso bien: el tesoro del alma. Volvamos a oír a Gadamer:

Se trata en Heráclito de proposiciones en forma de sentencias que ya en la Antigüedad eran célebres por su obscuridad y profundidad. Parece que Sócrates dijo que lo que él había entendido de ellas era excelente; y confia-

${ }^{132}$ Véase a este respecto la exposición de Gadamer en el cap. V de la Segunda Parte de Die Idee des Guten zswischen Plato und Aristoteles, op. cit., pp. 250-265. 
ba en que lo mucho que no había entendido también lo fuera. Hacía falta, desde luego, un buceador delio - un auténtico experto del buceo- para sacar a la luz el tesoro de las profundidades (...). Tal es el argumento del pensamiento en el Fedón. Sócrates muestra a sus amigos cómo el principio de la vida y ese otro principio del "pensar» y de la «anámnesis», son uno y así mismo igual de inseparables que el devenir y el ser (Anaxágoras supo unir ambas cosas).

Nótese, para empezar, cómo es de Heráclito, su descubridor, y no de los pitagóricos de quien aprende Platón, en el anterior pasaje traído, la filosofía del alma ( $p s y c h e ́$ ) como espontaneidad automotriz: como "principio de vida" - se nos dice-; el cual según está enseñando Sócrates, y recuerda Gadamer, es un principio que es uno y el mismo que otro principio diverso ¿Cuál?, ¿a qué otro principio diverso está unida el alma como consigo misma puesto que tiene una unidad de mismidad con ese otro? Parece que la respuesta no ha de ser fácil, pues se ha de notar también la silenciada alabanza que Gadamer, al parecer, dirige a Anaxágoras (metido entre paréntesis), del cual se nos dice que "supo unir ambas cosas». Con lo que se da a entender que triunfó - Anaxágoras, el sabio consejero de Perícles, el prudente- donde otros no acertaron. Pero ¿̨cuáles?, ¿qué cosas acertó Anaxágoras a unir? Parece que el "principio de vida" y «ese otro principio del pensar y la anámnesis» Es decir: el noûs, el espíritu. El principio del pensar - se nos dice - y de la «anámnesis. La cuestión se torna inquietante ahora, pues ¿no parece haberse multiplicado, imperceptiblemente, la pregunta y, para cuando nos hemos dado cuenta, haberse vuelto ya demasiado compleja? Como mínimo ambigua, porque, si vamos poco a poco: ¿no se trataba (y estaba ahí el problema) justo de la relación de mismidad y diferencia entre el alma como principio de vida y el espíritu como principio del pensar? ¿Qué pinta aquí, pues, de repente la «anámnesis»? ¿Es también la "anámnesis" lo mismo que el nô̂s y por eso es lo mismo que el alma-vida" o ¿son idénticos la rememoración y el pensar, que siendo otros respecto del alma-vida son uno-mismo con ella? También había dicho Gadamer citando a Platón que «la "anámnesis" es el recuerdo de lo verdadero»... Pero, para colmo, unas pocas líneas después ha escrito Gadamer, explicando el régimen intensivo y auto-incrementativo o reflexivo del alma, que Platón ha descubierto en Heráclito ${ }^{133}$, lo siguiente: "La vida tiene memoria de tal modo que se

133 Enseña Gadamer: «Fuera lo que fuera la psyché en el pensamiento griego temprano, la serie de declaraciones sobre el alma que hace Heráclito nos obliga a no ver sólo en la psyché ese algo que 
hace más al "experimentar» $y$ "se»" crece al recorrer el ciclo de la vida. Tal es el argumento del pensamiento del Fedón".

¿En qué quedamos?, ¿¿de qué lado está la memoria?: ¿¿del lado de la vida o del lado del espíritu? O jes que quizá no son la misma la memoria y esa misteriosa «anámnesis» que Gadamer escribe así y no saca ni de su transcripción del griego ni de sus comillas? Supongamos, ateniéndonos a la escritura, que la memoria y la "anámnesis" son distintas y que la memoria es de la vida, el alma la tiene — «la vida tiene memoria», se nos ha dicho-, mientras que la misteriosa «anámnesis" velada por sus comillas, como recuerdo de lo verdadero, parece acompañar en pie de igualdad al pensar, al espíritu.

Las «cosas" comienzan a ordenarse un poco, quizá incluso de un modo algo decepcionante, como pasa siempre con las analogías y las ecuaciones, cuando uno recuerda de repente con sobresalto que la enseñanza del Gadamer-Sócrates que está leyendo el Fedón y el Fedro en El inicio de la sabiduría terminaba de golpe en otro misterio: el del eterno retorno. Cuando decía, para reforzar la tesis de la unidad o mismidad de todo lo mencionado (el alma y su memoria, el pensar y la suya: la "anámnesis») estas palabras: «Son uno, y asimismo igual de inseparables que el devenir y el ser (Anaxágoras supo unir ambas cosash). Ciertamente la referencia a Heráclito parece abrir la buena pista: estamos en el lógos de la dialéctica. Y, según Gadamer, en la dialéctica de Heráclito igual que en la dialéctica de Platón, por lo que (para decirlo de un modo que sólo resultaría escandaloso para los seguidores de Nietzsche) nada puede extrañarnos ahora si ¡Sócrates en persona esté enseñando el eterno retorno! : «la máxima proximidad entre el devenir y el ser", de acuerdo con la hermenéutica de Gadamer, quien dice así:

El encender-se del fuego, el mover-se de lo vivo el volver-en sí del que se despierta y el pensar-se del pensar son manifestaciones del logos uno que siempre es. Es al misterioso «se» al que se dirige toda la profundidad de Heráclito. De un modo inimitable sostiene el centro único que se le ha perdido a la reflexividad de la autoconciencia en el pensamiento moderno: háptetai

vivifica, que se evade con el último suspiro. (...). Partamos de que lo que aquí se mienta no es la luz del sueño sino la claridad de lo que llamamos "conciencia" - y desde luego que lo es como el despertarse repentino del sueño, un "volver en-sí» (heautôt $t$ ) . Sólo entonces alcanza el lógos heraclíteo toda su fuerza expresiva (...) sorprendentes declaraciones sobre la psyché y su lógos. Que el logos del alma "se multiplica a sí mismo" (...) «se» multiplica, "se» despliega, "se» mueve y al final «se» busca. Este "se" es el que se haya en toda inversión de uno y lo mismo (...)». Ibíd., pp. 81-82. 
heautôi (...) Se comprende a partir de aquí —sigue Gadamer-cómo la pregunta platónica por lo uno y lo múltiple podía reconocerse en las musas tensas de la Jonia. La visión de Heráclito, según parece, miraba conjuntamente la vitalidad, la conciencia y el ser. Precisamente este cometido de pensar junto lo que está separado era lo que se proponía Platón. El Fedón relata muy plásticamente esa historia que comienza con el principio natural del "alma", diciendo que la vida no puede ser sin cerrarse en un ciclo. Por eso la naturaleza, con un retorno rítmico, renueva la vida una y otra vez, de modo que no haya muerte para ella. Pero esto es sólo un aspecto de la vida y el alma. Está también la vida, para la que la muerte es algo, porque un hombre es otra cosa que un eslabón en la cadena de la vida que rueda rítmicamente. La vida tiene memoria ${ }^{134}$.

La discusión y la estrategia de la hermenéutica presocrática de Gadamer logran ya dibujarse con bastante claridad. También los interlocutores. En efecto, un Platón-Sócrates heraclíteo y maestro del eterno retorno, pero no al modo repetitivo de la rueda de la naturaleza, sino al modo intensivo y reflexivo de la vida del alma y el espíritu, propiamente humanos. Lo cual desmontaría, en principio, a Nietzsche, o mejor dicho, a la crítica de Nietzsche a la metafísica platónica y a la historia del cristianismo-platonismo de Occidente. Pues tal crítica genealógica se centra precisamente en las pretensiones hipostasiadas de la Metafísica de la Historia, que se desenmascaran con Nietzsche en base a la recusación del tiempo lineal histórico y su causalidad eficiente o genésica. Procesos que llevados hacia atrás, disuelven todo Fundamento; tal es, esquemáticamente, el proceder de la genealogía crítica nietzscheana. Pero si ahora Gadamer descubre un Sócrates-Platón heraclíteo y maestro del eterno retorno, podría alcanzar al centauro arquero del Zaratustra en el centro del la diana y con un dardo de fuego. Pues si en nombre de Heráclito proponía Nietzsche la crítica disolutoria de la tradición de la metafísica platónico-cristiana, lo mismo haría Gadamer invirtiendo el nietzscheanismo, al descubrir ahora a Heráclito nada menos que replegado en el alma de Platón, cuya filosofía del alma no sería ni pitagórica ni cristiana sino radicalmente heraclítea. En cuyo caso, ambas filosofías del alma y la subjetualidad, la de Heráclito y Platón, no subsumidas en la autoconciencia moderna (nos ha dicho Gadamer) ni en la incorporación cristiana que las absorbiera modificándolas, esta-

134 Ibíd., p. 82. 
rían por redescubrirse y releerse desde ellas mismas y con su propia voz, esclareciéndose mutuamente entre sí, Platón y Heráclito, gracias a la «anámnesis» de la vida espiritual del pensar que retorna hacia el origen nuevo de nuestra memoria hermenéutica. Así abriendo el futuro de otra epocalidad: la que «resucita de entre los muertos": la epocalidad hermenéutica. La era del lógos espiritual y la Pietas de la Hermenéutica, después de la Modernidad. Es decir: después de la historia de la cristiandad y sus secularizaciones modernas e ilustradas ${ }^{135}$.

Dentro de un momento volveremos sobre este asunto de la resurrección heraclítea en Gadamer y su relación con el eterno retorno hermenéutico, pero como mínimo es hora de plantear también una posibilidad interpretativa que, lejos de contravenir la hipótesis barajada hasta aquí, podría, al contrario, venir a sumarse a ella. A saber: supongamos que la inversión del platonismo preconizada por Nietzsche se pusiera en relación, de una vez por todas, con la tesis del "eterno retorno" tomada como hipótesis y metodología estético-hermenéutica (¿y cómo podría ser de otro modo en el caso de Nietzsche?, ¿o es que «el eterno retorno" de Nietzsche podría ser para él una tesis descriptiva sobre el tiempo físico y metafísico ${ }^{136}$. Entonces, en vez de tratársela como si pudiera ser una hipótesis fisica o cosmológica descriptiva, la tesis estético-hermenéutica del «eterno retorno", puesta en conexión con la propuesta histórico-político-hermenéutica de la inversión del platonismo, apuntaría jexactamente como lo hace en Gadamer! a la arqueología presocrática de Platón ${ }^{137}$ por debajo de las capas de lecturas cristianas (y sobre todo cristiano-secularizadas o modernas: ateas y agnósticas), haciéndonos desembocar entonces, como a Gadamer, en el vertiginoso estrato de un Heráclito religioso y délfico, dionisiaco, que habría traducido los misterios délficos en la más radical y originaria filosofía de la resurrección pensada por Occidente.

${ }^{135}$ Resulta imposible no evocar aquí la filosofía de uno de los más fieles y originales discípulos de Gadamer: Gianni Vattimo, uno de cuyos últimos libros se intitula precisamente así: Dopo la Cristianità. Per un cristianísimo non religioso. Ed. Garzanti, 2002. Véase al respecto: "La contribución de Gianni Vattimo a la hermenéutica del siglo XX", op. cit., pp. 99-154.

${ }^{136}$ Véase la importancia que para Gianni Vattimo tiene precisamente esa des-ontificación del "Eterno Retorno" de Nietzsche, que no puede ser tomado como una tesis metafísica, sino hermenéutica. Cfr. Diálogo con Nietzsche, especialmente pp. 31-62.

137 Dice Gadamer: «En Platón todavía es donde más se siente algo de la concisión y agudeza de su pensar (el de Heráclito) y de la penetración de sus sentencias, como cuando se dice en el Sofista (242 a) que las musas jonias de Heráclito son más tensas que las sicilianas de Empédocles, y reconoce así en las palabras de Heráclito cómo están decretados lo uno y lo múltiple, la separa- 
Entonces sí podríamos saber quién es el Zaratustra de Nietzsche: ¿̨pues cómo no iba a ser Heráclito: el maestro del eterno retorno y de la suprema esperanza? ¿Y no reza así el aforismo 18 de Heráclito que Gadamer traduce y comenta?: «Si uno no espera, no encontrará tampoco lo inesperadon. "Es gracias a la esperanza - sigue Gadamer- que lo que aparece, precisamente porque era imprevisible y parecía inalcanzable, pudo presentarse de un modo totalmente diferente a lo que se esperaba. Entonces puede haber una sorpresa. Podría haber un cumplimiento. Sólo al que tiene esperanza se le puede enviar lo inesperad ${ }^{138}$ ".

Porque entonces, interpretando a Heráclito desde su esencial proveniencia (la precedencia que Heráclito como hijo o heredero hace posible al constituir en tradición filosófica la sabiduría del límite de Delfos ${ }^{139}$ a la que él se remite y que él continúa), se invierte su posteridad receptiva (en este caso la platónica vista desde el posterior cristianismo), se logra interpretarlo de acuerdo con el método hermenéutico del eterno retorno o la Wirkungsgeschichte de Gadamer ${ }^{140}$. Lo cual sí

ción y la unión, que se plantean como tarea para la propia dialéctica platónica" (El inicio de la sabiduria..., op. cit., p. 18), «Es además muy significativo que en los diálogos platónicos se mencione y se cite a Heráclito con particular veneración» (ibíd., p. 14). «Donde mejor se encuentra una tensión y una precisión comparables de la expresión es en los cantos corales de la tragedia, a los que les gusta la contraposición dialéctica como correspondencia poética a los pasos de danza del coro. Pero en Heráclito se trata, claramente de una prosa gnómica, cuyo mayor misterio es la parquedad en las palabras" (ibid., p. 20). Y para continuar con los rasgos del estilo de los aforismos que expresan la acción intensiva de la metabolé heraclítea instantánea, sin génesis ni movimiento extenso, y sin sujeto subyacente que inscriba la diferencia intensiva de los contradictorios y los contrarios en ningún concepto, elenca Gadamer: «La sentencia paradójica, el símil, la proporción y también la analogía asimétrica. Se trata, pues, de desvelar, a partir de lo morfológico, las paradójicas intelecciones de Heráclitom (ibíd., p. 47).

${ }_{138}$ H.-G.Gadamer: El inicio de la sabiduria..., op. cit., p. 67.

139 Para estudiar la estricta continuidad entre las ontologías del límite y la sabiduría de Delfos, véase El nacimiento de la filosofia en Grecia, op. cit., especialmente el cap.V, pp. 84-101, y el cap. VI, pp. 101-114.

${ }^{140}$ En este sentido consideramos que debe entenderse la importancia central que Gadamer otorga a su descubrimiento del carácter fidedigno - atribuible a Heráclito como texto que expresa un genuino pensamiento del Efesio- del fragmento relativo al hijo y al padre, que Gadamer pretende según sus propias palabras: «Sacar de Hipólito un nuevo fragmento que por ahora está ausente de las colecciones" (ibid., p. 21). En realidad la tesis central del estudio "Sobre la transmisión de Heráclito" es esa misma: que "el hijo hace al padre" en el sentido del "eterno retorno" como método de la hermenéutica, pues sólo remontándonos a la referencia que lo posterior "eligem establecer respecto de lo anterior que toma como apelación y pregunta, enigma o reto, puede evitarse sepultar la diferencia del pensar dialogal, que siempre es ya una respuesta, en las recepciones posteriores que lo integran olvidando su tensión, su problema-pregunta originaria: Aque- 
nos permitiría advertir una última-primera figura simbólica del lógos de la luz benévola, nunca advertida por los intérpretes hasta Gadamer. Un lógos cuyo enlace, cuyo puente, fuese esta vez el arco iris de una esperanza que no puede no realizarse. El otro lado del rayo como súbita luz en la noche poniendo en relación el cielo y la tierra. El arco iris, el rayo-puente diurno de la radical esperanza. Tal nos parece ser el centro de la hermenéutica heraclítea y presocrática de Gadamer, siguiendo a Platón-Sócrates hacia atrás ${ }^{141}$.

Hacia atrás hasta encontrar al maestro del eterno retorno, y tras él, tras su máscaras de Zaratustra-Heráclito, al niño Dionisos jugando a abismarse en el misterio del resucitar, con las máscaras de la risa y la muerte trágica. Dionisos, sonriendo enigmáticamente y jugando con sus curvos juguetes preferidos: el espejo donde se refleja el mundo de Apolo, el puente del lógos nocturno como rayo y del lógos diurno como arco iris: los puentes de la tierra celeste, surcando la suprema esperanza de lo súbito, de lo que puede cambiar por completo en cualquier momento, sin mediación, en un instante, y darse la vuelta hacia lo desconocido, hacia lo radicalmente otro, absolutamente inesperado, que ya estaba allí como otro, tensado por el extremo de la distancia diferencial, propia de las síntesis disyuntivas, $y$ ahora puede, de repente, darse la vuelta y aparecer, súbitamente, con la velocidad del rayo y la efímera belleza de la lluvia en el sol ${ }^{142}$. Aparecer-desa-

lla en vista de la cual, hacia atrás, se pone en interlocución (cfr. ibíd., pp. 21-25). Sólo así puede ocurrir lo que concluye Gadamer en este caso hermenéutico paradigmático: «Debajo de la capa cristiana ha aparecido, desde luego, un color original completamente diferente: la unidad del engendrar y del ser engendrado" (ibíd., p. 25). Una unidad indivisible o intensiva que se enlaza por la diferencia entre los extremos sin mediación (cfr. ibíd., pp. 24-30).

${ }^{141}$ Dice Gadamer: "Heráclito veía (como Platón) que el fuego y el calor son en el fondo una y la misma cosan (ibíd., p. 29). Sobre Platón como el testigo más antiguo de Heráclito, cfr. ibíd., pp. 35-39; allí destaca Gadamer con acierto «la simultaneidad del dispersarse y el unificarse. A Heráclito se le atribuye que lo uno y lo plural no son algo sucesivo, sino que son a la vez toda la verdad del ser" (ibíd., p. 37).

${ }_{142}$ Escribe Gadamer: "Así, al menos, debía de religar Heidegger su propio preguntar con la profundidad de Heráclito, pues para él la obscura misión de su pensar no era como para Hegel la omnipresencia del espíritu que se sabe a sí mismo (...) sino justamente esa unidad indisoluble y dualidad de desvelamiento y ocultamiento, claridad y obscuridad en la que se encuentra inserto el pensar humano (...) detrás de esto tiene que estar lo sabio-uno (hén-sophón) que le da que pensar en el caso de la muerte del héroe y la veneración de los héroes. Pienso que lo que le preocupa es lo subitáneo e impredecible en el cambio de las cosas: igual que la muerte en la batalla propicia la elevación y transfiguración del caído (...) En su base está el interés de ver conjuntamente con el fuego a la psyché y al pensar (...). Lo que se describe con esto como fenómeno en cuanto fenómeno es bien claro: el repentino saltar de la llama que sale de un leño calentado (...). «Un hombre 
parecer ¡totalmente transformado su sentido! por la resurrección inmanente e inagotable de los pasados posibles. "Y el todo lo gobierna el rayo" (Fr. 64). Con la misma suavidad y radicalidad del despertar: del volver en sí y el ausentarse en el dormir. Éste es el espíritu del alma de la racionalidad hermenéutica: el aparecer-desaparecer de la memoria de la verdad; y constituye la esencia simbólica actual de la racionalidad hermenéutica que nos vuelve a descubrir el Gadamer presocrático seguidor de Heráclito y del dios Dionisos-Apolo. el filósofo y el dios del límite inseparables, cuya única palabra indivisible alcanza la resurrección inmanente de los mundos. La resurrección teológica propia de la filosofía, profundamente religiosa y piadosa, entregada a la vigilia y al cuidado hermenéutico de todo lo posible que sí puede retornar. Ésta es la suprema esperanza, cumplida cada vez por la filosofía y en la filosofía del lógos, desde la resurrección que Platón y Aristóteles efectúan ya con los presocráticos, cuya palabra comparten e interpretan transformada, para transmitirla a la eternidad de su recreación, mientras dure Occidente. Ésta es la enseñanza de Gadamer en El inicio de la sabiduría occidental. Pero veámoslo aún más de cerca.

Por el momento se ha de retener que Gadamer, leyendo el Fedón y el Fedro platónicos, ha distinguido entre dos tipos muy diversos de memoria y de retorno, a cada uno de los cuales corresponde un tipo de resurrección del alma: la memoria rítmica de la vida natural y la memoria del pensar como «recuerdo de lo verdadero».

¡Qué cosas dice Gadamer en los textos del Der Anfang des Wissens que estamos trabajando! Pues si la diferencia se traza entre un eterno retorno al que se llama "rítmico", aludiendo explícitamente con ese término tanto a la ciclicidad del orden-justicia cosmológico de Anaximandro como al arithmós pitagórico, o sea, al Número del alma corporal rítmica y armónica, entendida como estructura y equilibrio del cuerpo ( $k r a s i s$ ), entonces tanto el alma física del hombre como el alma física del Kósmos quedarían de un lado: el de la memoria de la vida-alma natural, que habrían tratado tanto los milesios como los pitagóricos: los fisicos. Por

prende en la noche una luz para sín (...) lo asombroso de este fenómeno es que tenga lugar sin transición. Ocurre de pronto, todo se hace distinto de repente al encenderse la luz (háptesthai, Fr.26), como en la aparición del rayo, como en la claridad del pensamiento que se enciende (...) es la imposibilidad de concebir un tránsito sin mediación lo que le da que pensar y le da a pensar "lo uno" (...) la ausencia de transición en estas transiciones del sueño al despertar o de la vida a la muerte, apunta, en definitiva, a la experiencia enigmática del pensar que despierta de pronto y que luego vuelve a hundirse en lo obscuro". Ibíd., pp. 18-30. 
contraste Heráclito y Platón, sin embargo, tan próximos entre sí como el padre y el hijo espiritual que lo relee, lo sigue y lo continúa filosoficamente, habrían defendido al unísono una "anámnesis" del pensar espiritual (del noeîn). Pues si el alma natural resucita en otro semejante y sin memoria individual, como lo hace la naturaleza a través de los ciclos de las estaciones y las generaciones, al otro tipo de alma, a la sobrenatural o espiritual —de la que Gadamer ha dicho que es aquella que sí tiene experiencia de la muerte en vida y sí le importa la muerte, es decir: la del hombre consciente- a esta otra alma-vida que es la del pensar y la "anámnesis» ha de corresponder una, digamos, "resurrección hermenéutica de los muertos». Ya no genéricos, semejantes, o del mero tipo específico, sino de los muertos máximamente singulares y comunitario-comunicativos a la vez. Precisamente los que responden al modo del lógos heraclíteo que comparten por participación en su unidad intensiva todos los pertenecientes a la vigilia.

Dice Gadamer:

Una sentencia como «Para los que están despiertos el orden del mundo es uno y común, mientras que cada uno de los que duermen se vuelve hacia uno propio" (fr. 89) también tiene aquí su sitio. (...) De este modo, en el fragmento 21 no leemos, como sería de esperar, una correspondencia entre el dormir y los rostros del sueño, de un lado, y el estar despiertos y el mundo de la vigilia (vida) del otro. Antes bien, se dice de modo provocativo y sorprendente: «Muerte ( $y$ no vida) es cuanto vemos despiertos; cuanto vemos dormidos, visiones reales" (...) la exactitud de esta sentencia templada al martillo, se hace así perfectamente clara (...) sueño y dormir representan la ceguera (Verblendung) que consiste en no estar en condiciones de reconocer uno y lo mismo en todo lo múltiple que nos encontramos (...) la sentencia muestra que todos los hombres cometen el error de considerar a los opuestos como entes separados en lugar de reconocer la verdadera unidad. Ésta es la paradoja: él quiere des-componer este ser-uno, y éste es el lógos al que hay que escuchar $^{143}$.

Y Gadamer concluye:

En todo caso hay que llegar al conocimiento de que lo otro siempre está ya ahí. La mejor prueba de ello es que lo contrario irrumpe de pronto y sin 
mediación. Lo que cambia por completo de golpe su aspecto y surge lo contrario. Ello demuestra que ya estaba ahí previamente (...) la mayor dificultad que tenemos para comprender estos testimonios la representa la oposición de vida y muerte (...) en Heráclito se trata del cambio repentino de la vida en muerte (...) para él se trata de la paradoja del cambio repentino y con ello del ser uno del ser. ¿Qué es la vida y qué es la muerte, qué es el surgir y qué el apagarse de la vida? Éste es el enigma sobre el que medita Heráclito (...) es el secreto de la naturaleza del ser mismo, lo Uno-Sabio, lo verdaderamente divino, lo que todavía se manifiesta en el brusco cambio de vida y muerte. Incluso la muerte es como una inversión repentina de la aparición del ser (...) El pensamiento de Heráclito es radical ${ }^{144}$.

Cuando en el fragmento 62 se habla de que los dioses "viven nuestra muerte» (...), para él sería, a lo sumo, un ejemplo dotado cúlticamente de la subitaneidad de semejante inversión ${ }^{145}$. (...) De este modo, también los inmortales son una particularización que no puede ser sin los mortales ( $\mathrm{fr}$. 62) (...) parece como si Heráclito, con un audaz pensamiento ilustrado, anticipando a Platón, pusiera al mundo tradicional de los dioses en una relación de intercambio con la experiencia humana del mundo (...) pero el pensamiento de Heráclito es mucho más radical $(. . .)^{146}$.

A partir de aquí quisiera plantear la cuestión general de si no se referirán todas las sentencias sobre la gloria y la inmortalidad, como los fragmentos 24,25 y quizá incluso el 27 , a la transformación de los muertos ${ }^{147}$.

Y añade Gadamer:

Clemente cita todo esto a causa del despertarse y el despertar, y desde su fe cristiana, estaba mirando a la resurrección, la promesa cristiana ${ }^{148}$.

144 Ibíd., pp. 54-64.

145 Ibid., pp. 65-67.

146 Ibid., Pp. 64-65 y 68.

147 Ibíd., p. 68. Y cita Gadamer a Heráclito comentando: «Vivo entra en contacto con el muerto. Despierto entra en contacto con el durmiente» (...) vigilia y sueño, vida y muerte, se tocan de modo inmediato (...). "Encender" significa "tocar" (...) en la vigilia y el sueño, concibe él lo unosabio (hén tò sophón) de la muerte y la vida". Ibíd., pp. 76-77.

148 Ibíd., pp. 77-78. Véase también el elogio del cristianismo de la resurrección que Gadamer pondera en estas mismas páginas (ibíd., pp. 60-63), diferenciándolo, no obstante, del pensamiento heraclíteo de la resurrección espiritual inmanente. 
Pero según todo lo visto, tanto para Heráclito como para la hermenéutica trágica de Gadamer, la indivisibilidad de la vida y la muerte es tal en el lógos común, por lo que más bien ha de tratarse de una resurrección espiritual comunitaria y comunicativa de los muertos: de su-nuestra palabra máximamente personalizada y comunicada a través de la reinterpretación que los vivos brindan a sus-nuestras ideas-palabras y obras precisas, literales, al adentrase en "el recuerdo de lo verdadero" de los pasados posibles ${ }^{149}$.

En muy pocas líneas de una condensación forjada al fuego de la memoria intensiva, evoca Gadamer en su Der Anfang des Wissens, sin apenas nombrarlo, uno de los más antiguo mitos de Occidente: el conmemorado por el ritual del santuario de Delfos: el de Démeter y Perséfone ayudadas por Diónisos a reencontrarse para que del invierno oculto en las entrañas de la tierra vuelva a brotar la primavera ${ }^{150}$; saltando después Gadamer desde Delfos hasta el eterno retorno espiritual de Nietzsche, pensado desde el Andenken de Heidegger, quien en la cabaña de la Selva Negra tenía grabada sobre una corteza, encima de la puerta de entrada, la sentencia de Heráclito que explicita la primacía del límite intensivo-simple sobre cualquier síntesis y sistema de orden: « $Y$ el todo lo gobierna el rayo" (Fr. 64) ${ }^{151}$.

149 La unidad oculta entre los muertos y los vivos, o entre la vida y la muerte, alcanza en el pensamiento trágico de Heráclito su máxima radicalidad. Tal unidad intensiva es la del repliegue de los extremos que se encuentran, se tocan y se cruzan o alteran mutuamente cambiándose de repente el uno en el otro. Por eso -dice Gadamer: «Su lógos es uno. Heráclito lo percibe en fenómenos tan diversos como el fluir de las cosas, el brusco cambio de fuego a agua, del dormir al despertar, $y$ descubre el mismo enigma en todo (...) en todas partes ve el milagro de la vida, el enigma de la vigilia y el misterio de la muerte. Se mostrará que este es uno de los puntos en que Platón asume positivamente el pensamiento heraclíteon (ibíd., p. 49). Comprensión que viene a ser corroborada cabalmente por otro de los últimos libros de Gadamer: El Estado oculto de la salud, donde se encuentran dos textos complementarios que vierten esta misma hermenéutica trágica de cuño presocrático: Se trata de "Experiencia de la muerte» y "Vida y alma». En ellos ahonda Gadamer en la interpretación del origen del lenguaje como culto a los muertos que les devuelve la palabra en la vigilia del sueño, a fin de que no se interrumpa la conversación de la memoria creativa del lógos. comunitario. El espléndido estudio de Gadamer: "fenomenología del ritual y del lenguaje», de los años 90 , trabaja en la misma dirección remitiéndo esta vez igual al lógos de Heráclito que al noeîn de Parménides, pero, sobre todo, al espíritu del lenguaje en Aristóteles. Es decir a la teología filosófica del noêin. Para las ediciones originales y las traducciones al castellano de todos estos escritos de Gadamer véase notas $112-117$ y 163 y la bibliografía al final.

150 Sobre los misterios eleusinos como rituales de resurrección inmanente para la religión délfica griega véase el cap. VII del estudio "Hacia Mileto", en mi libro El nacimiento de la Filsososia en Grecia, op. cit., pp. 114-146.

${ }^{15 t}$ Cfr. H.-G.Gadamer: El inicio de la sabiduria..., op. cit., pp. 34-35. 
La rememoración que pone en juego Gadamer leyendo a los presocráticos resulta tan intensa, $\tan$ coherente y tan asombrosa ${ }^{152}$ como aparentemente fácil parece resultar Gadamer para sus lectores contemporáneos. Tan fácil de digerir como de criticar, mientras la hermenéutica va haciendo su trabajo de alquimia en ellos sin que lo noten en exceso. Pensamos, a menudo, que no se han dado cuenta de lo oculto que Gadamer pone en juego, debido a que el olvido moderno de lo uno-modal-oculto-intensivo, replegado ${ }^{153}$ es tan profundo como para no poder advertirlo siquiera. Y que si no fuera porque mientras el dorado caldo del lenguaje de Gadamer se pone a circular por las venas de la memoria oculta, resultando a su paso la memoria consciente enteramente trastocada, no se podría estar produciendo (como historia de los efectos de la racionalidad hermenéutica productiva actual) la profunda transformación registrable que exhibe hoy la tópica de nuestras creencias y convencimientos históricos. En efecto, los cuadros de sus asignaciones de re-conocimiento y sus líneas divisorias han sufrido desde los años sesenta en adelante una transformación hermenéutica tan decisiva como para desembocar hoy en la racionalidad de la época hermenéutica postmoderna como en una nueva-antigua koiné, inédita para la racionalidad de Occidente y para el espíritu del diá-logos originario.

\section{II.4. El cruce tensional de la diferencia. Dialéctica del alma y resurrección trágica.}

Lo cierto es que resulta muy difícil no dejarse convencer por "Los Presocráticos de Gadamer» y, como mínimo, se debe prestar a este mismo fenómeno retórico el rango de una cuestión intra-hermenéutica de primer orden. Veremos en

152 Cita Gadamer a Heráclito: «Muerte y no vida es cuanto vemos despiertos; cuanto vemos dormidos visiones reales"; y comenta a continuación: «Los dos valores extremos los representan la muerte y el sueño cuya correspondencia habla por sí misma. Lo provocativo de este símil es que comienza de un modo sorprendente, En el primer miembro, lo que se adaptaría al proceso es vida $y$, sin embargo, se dice muerte. Lo visto en la vigilia como un todo, con su vigilia aparente se atribuye entonces no a la vitalidad sino al estar muerto" (ibíd., p. 55). La comunidad intensiva entre vivos y muertos es tan indisoluble como para que el cruce oculto entre ambos explique el pensar como un modo de culto a los muertos en que se reanuda la conversación, sólo aparentemente interrumpida por su ausencia. La vigilia del sueño entre ambos extremos cruzados explica el olvido diurno del despierto en el despliegue extenso de los contrarios y contradictorios. Cfr. ibíd., pp. 54-62.

${ }^{153}$ Sobre la condición modal de lo divino inmanente y su unidad modal intensiva, que no pertenece al campo de las determinaciones semánticas ni numérico-extensas, se expresa Gadamer en 
seguida por qué decimos esto si seguimos permitiendo que entren en la conversación de la memoria espiritual algunas más de las voces del pensamiento convocadas por la provocación de la flecha "Platón-Heráclito", la cual, dicho sea entre paréntesis y otra vez, no puede ser desechada sino confirmada, desde los textos conservados (de ambos filósofos). Y ello en la rigurosa medida en que les abre muy precisamente la posibilidad de ser leídos con una insólita coherencia y con una hondura inusitada.

Sigamos en esto. El guiño a Anaxágoras del socrático Gadamer ${ }^{154}$ vuelve a subrayar, en efecto, que la comprensión del alma platónica ha de distinguirse con sumo cuidado del concepto de corte médico del alma, propio del pitagorismo, tal y como razona convincentemente Gadamer, en El inicio de la filosofia occidental. Pues, en efecto, como parece estar claro en cuanto uno se detenga a considerar la cuestión, tampoco ha defendido nunca Platón que el alma fuera la armonía (krâsis) del cuerpo, como sí sostenían los pitagóricos. Más bien al contrario, y por considerar sumamente problemática la posibilidad de alcanzar esa indispensable armonía, es por lo que se tiene, al parecer, a Platón por «dualista». Por eso dice Gadamer alegando el Fedón:

A la objeción de Simias, Sócrates responde que el problema no se plantea en los términos en que él lo ha presentado, porque el alma no se identifica con la armonía. A lo sumo la armonía es algo que el alma trata de establecer o encontrar. El alma armoniosa no es un dato natural, sino un bien hacia el que se orienta la vida. Me parece claro que aquí podemos leer el conflicto entre una teoría naturalista o, si se quiere, matemática de la armonía, dependiente de los elementos que la componen, y una teoría finalista, por así decirlo, o sea: de la armonía como finalidad de la vida ${ }^{155}$.

Y si el asunto reviste tanta importancia para nosotros es porque al permitir confirmar que uno de los trazos más característicos de la hermenéutica gadameriana de los presocráticos reside en el descubrimiento del Platón heraclíteo y no pitagórico, ello logra a la par colaborar con Gadamer en uno de sus más caros objetivos: dejar libre a Platón de la crítica sistemática y radical que Aristóteles

este mismo estudio, recabando la ayuda del excelente libro de W. Jaeger a este propósito: La teologia de los primeros filosofos griegos. Véase ibíd., pp. 51-52 con sus notas respectivas.

154 bíd., p. 13.

155 H.-G. Gadamer: El inicio de la Filosofia occidentah op. cit., pp. 51-52. 
dirige contra las pretensiones filosóficas del pitagorismo. Al cual considera, como sabemos, una secta violentamente mitológica pero no una verdadera filosofía, por mucho que ésta se arme con la música y la matemática de las que hace, en realidad, un uso materialista abstracto, marcadamente instrumental-cuantitativo, e indiferente, en último término, al bien ontológico de la vida y del ser. Estándolo, como lo está, solamente interesado, el pitagorismo, en conseguir el poder: el dominio matemático de la realidad, por una parte, y la salvación del alma del hombre, más allá de la muerte del cuerpo y del mundo sensible, por la otra.

Lo complejo está en que Gadamer comparte tal crítica, la cual viene a hacer suya por entero, como se comprenderá con facilidad si se tiene en cuenta cuál es la orientación emblemática de la hermenéutica a partir de la crítica al positivismo cientifista que irrumpe con Verdad y Método. Por eso el asunto resulta muy delicado y se corre el riesgo de malentenderlo si no se tiene en cuenta que la unidad dialéctica entre Heráclito y Parménides se descubre, de manera clamorosa, en cuanto se advierte que ambos filósofos se dirigen por igual contra el pitagorismo. Cuya polymathía superficial (para Heráclito) y profunda errancia (para Parménides) vendrían ambos ontólogos a tratar como una suerte de repetición erudita de los dogmas del sentido común y los mitologemas de los mortales. De ambos filósofos presocráticos se nutriría Aristóteles en su crítica radical contra los pitagóricos y la pitagorización de la Academia. Recuérdese, por ejemplo, la crítica del Estagirita en el libro primero del De anima al materialismo (genético, cinetista) del alma pitagórica, entendida como forma, armonía o estructura del cuerpo que se mueve y mueve al mover. Pues hay que matizar, como pide hacer Aristóteles, que no es el alma lo que se mueve sino el compuesto, por ejemplo el hombre, o el animal a causa del alma. El famoso hilemorfismo escolástico latino, proyectado por las lecturas substancialistas sobre Aristóteles - como mínimo a partir de Boecio- sigue aún estorbando, de modo muy espeso, la posibilidad de que nosotros comprendamos una cuestión tan esencial como ésta y tan desconcertante aún para nuestros prejuicios. A saber: que la crítica y el disenso más radical de Aristóteles respecto del Platón italianizado o pitagorizado se centra en el reproche y el núcleo del materialismo dinámico o abstracto, tanto cinético como lógico (según se trate del movimiento de los compuestos con materia física o del discurrir que opera con los compuestos y las unidades lógicas de materia - cantidad- abstracta) ${ }^{156}$.

${ }^{156}$ Tanto en El nacimiento de la Filosofia... como en Para leer la metafisica de Aristóteles en el siglo $X X I$, ya referidos, he desarrollado de modo sistemático el análisis de los motivos de la crítica 
Es por ese motivo por lo que el Macedonio acusa a los platónicos de haber olvidado el alma espiritual noética, habiéndola llegado a confundir y reducir al alma corporal psicológica; igual que reduce y confunde la dialéctica académica, a ojos de Aristóteles, la acción (prâxis kaì enérgeia kai entelécheia) con el movimiento de las potencias o fuerzas perfectivas (kinesis ek dynámeos), viniendo a mutilar y rebajar así, sistemáticamente, la vida y el deseo del pensar espiritual que es propia de las acciones más excelentes: las acciones virtuosas espirituales propias del noein que reúnen lo divino con lo divino en el hombre. Tales virtudes dianoéricas, las acciones mejores de entre las superiores, no pueden ponerse al servicio del estadio inferior del alma humana y su deseo demasiado humano, como si hubieran de obedecer al alma de la memoria discursiva, la imaginación, la libertad, el razonamiento judicativo, y los sistemas de orden - el moral, cosmogónico, tecnológico-político, etc.-, porque su condición es superior y exterior al hombre aunque en su praxis resida la vida más alta y mejor: la del alma espiritual que es lo más divino en el hombre y se ocupa de lo divino inmanente que hay en todos los seres.

Lo cual, en una palabra y usando el lenguaje del propio Aristóteles en Ética a Nicómaco, equivaldría en general a reducir la sophía a la phrónesis, y lo que hay de divino en el hombre a lo humano, basándose en que se puede sobrevivir sin la sophía y el hombre puede independizarse de ella en pos de su autonomía absoluta. No siendo lo contrario equivalente, pues la sophía no puede darse sin la phrónesis. No puede darse sino cuando ya se dan la justicia, la comunidad, ciertos bienes materiales y todos los sistemas de orden necesarios para permitir, entonces, la verdadera vida-buena y su placer: ese exceso, ese extraser de lo ético, ese intenso placer ontológico que desea volver y que como una consecuencia gratuita y añadida abre el ámbito de lo divino inmanente aquí y ahora para los hombres: el de la acción-contemplación y la investigación comunitaria del bien ontológico y lo divino en todos los seres, para empezar por la contemplación de las acciones excelentes dianoéticas, en el ámbito de la amistad y al amparo de la comunidad filosófica.

En efecto, no se trata aquí sino de la distinción entre el bien ontológico-ético (o dianoético) y el bien moral-político, que en la auto-interpretación de Aristóteles mismo equivale a trazar, una vez más, la diferencia entre acción y movi-

de Aristóteles a Platón son justo los del último Platón, desde los diálogos del Parménides y el Sofista hasta las Leyes. Remito a El nacimiento de La Filosofia en Grecia, op. cit., para el criticismo documental pertinente de la mayoría de los desarrollos que siguen. 
miento, dando lugar a la comprensión ahora de la diferencia entre sociedades míticas y sociedades autocríticas. Pues, en último término, la diferencia afecta a la comprensión cabal de cómo para todas las culturas afilosóficas el primado corresponde a la génesis, la memoria repetitiva de las costumbres normativas, la producción técnica y, en una palabra, el orden del movimiento y la producción. Sucesión que se rige por el supuesto orden que resulta de asimilar la causa al origen «según el antes y el después». El orden que es propio del número y del tiempo cronológico del trabajo-descanso, sin dejar lugar al otro plano: ese diferente que el poder y su administración, por sí mismos, no pueden nunca descubrir. El ámbito excedente: el de la excelencia del ocio activo comunitario que se da en la única comunidad superior a la de la pólis institucional (que tampoco han descubierto los bárbaros que viven sin leyes objerivas): el espacio de la comunidad por y en la amistad, la filosofía, la investigación y la enseñanza. Un primado que prefiere y defiende el modo de vida propio de la acrividad comunitaria dedicada a la investigación filosófica y epistémica sobre todos los restantes, debido a que sólo este modo de vida realiza y ofrece las condiciones de la máxima singularización del individuo en el seno de la comunidad (que puede ser) más verdadera: la academia. Y ello a su vez debido a cómo, en todos los órdenes, responde ese otro plano a la primacía de la intensidad y la reflexividad de lo eterno inmanente sobre lo extenso relativo.

En efecto, en este ámbito superior que está también aquí y ahora, la temporalidad no es ya meramente la de chrónos, sino esa otra temporalidad intensa que se abre por la eternidad inmanente del aión (instante eterno). La temporalidad libre que corresponde al acontecer extático de la experiencia de la verdad-límite que se da, a partir de la crítica, en el descubrimiento propio del aprendizaje y se consuma en la transmisión diferencial. Es decir: en la temporalidad también eterna pero además continua del tiempo del aidion como eternidad durativa. La temporalidad que, en efecto, es propia de la transmisión siempre transformada del sentido, permitiendo la existencia de los saberes, las ciencias, las bibliotecas, las instituciones culturales $\mathrm{o}$ artísticas vivas, etc. Ambas temporalidades - la investigación dialéctico-crítica y la transmisión que la conserva y revisa- son tan indispensables para la vida académica libre y la vida cultural-artística libre como lo son las acciones lingüísticas vivas en que se realiza y pone en juego la prueba de su vivir-pensar.

Pero si se confunde y usa el bien ontológico con el bien dinámico-genético, y la causalidad final del bien se confunde con la causalidad motriz potencial, viene a omitirse, entonces, la diferencia ontológica. Entre aquello que es-activo pero 
mueve sin moverse (sólo por la atracción que ejerce en el amor-deseo de lo que se mueve hacia ello: hacia y por el bien) y la muy distinta causalidad agente motriz. Con el resultado constatable de una inversión del sentido temporal que afecta a la casualidad condicional o referencial trastocando su orden, pues al dinamizarlo se relativiza el plano transcendental condicionante y queda olvidado el límite-limitante. Con lo que se olvida lo esencial. Es decir: que el bien mismo como límite-principio no se mueve, ni hace, produce o fabrica, en realidad, nada, sino que sencillamente es o es-está-siendo su ser-estar-activo. Plenamente activo y vivo, tal y como corresponde al estar-vivir bien en que consiste el bien del ser-acción, precisamente. Tan bueno, tan deseable como el vivir-bien, plenamente y disfrutando de su excelente modo de vida diferencial. Lo cual equivale a decir que el bien ontológico sólo es-está siendo en la orientación final contraria al movermoverse, com-ponerse, re-ferirse, di-vidirse, etc., porque son estos procesos mismos los que se hacen en vista del bien diferencial y plural de cada modo de ser y no al revés, tal y como sucede en el curso del tiempo cinético.

Por eso si tal inversión de los valores se opera, invirtiéndose también el sentido del tiempo ontológico por asimilarse al tiempo genético (como si el límitebien fuera un agente que estuviera ya antes de lo organizado, y se compusiera al mover-organizar-pensar los repertorios inconexos de lo múltiple, pasando a hacérsele operar, al bien, como si de un origen material o un "desde donde" o un "a partir de" genético se tratara), entonces todo ya, sin excepción, estaría aplanado en el ámbito potencial. Reducido a un único plano de repetición indiferente e infinita: el del poder potencial y la lucha de fuerzas concurrentes por la sobrevivencia. Como si todo ya pudiera reducirse a una guerra de fuerzas y prevalencias entre los competidores: los contrarios entre sí, pugnando a muerte por afirmarse negando los unos a los otros para ocupar el lugar del dominio presente. Ya todo sería voluntad de poder y perdería entonces el bien ontológico, la simplicidad indivisible modal, gracias a la cual únicamente puede ser el noê̂n como arché-péras. Estando en ese otro plano (que es el de la intensidad plural de las diferencias sin contrario), y siendo el primer principio-límite ontológico. Princípiolímite activo, inmóvil y separado o simple: sólo acción-ser-pensar de las series referenciales que se auto-ordenan en sistemas de síntesis, en vistas a lograr su modo de estar-bien y por el deseo de su propio bien o plenitud. En resumen: que si se operan todas esas inversiones propias de la incorrecta reducción y asimilación de las causas primeras al origen, se produce, en general, una confusión material-extensa-cinética, desde la cual, inadvertidamente o no, se estará enunciando la acción del hacer-pensar del noeîn espiritual (que consiste en ser-límite 
diferencial simple «separado» $\mathrm{y}$ «separador» [choristón]) sólo «de nombre» -o como dice Aristóteles «accidentalmente» o "potencialmente»-.. Y por lo tanto de manera inversa, decaída, rebajada e impropia, respecto de su acción espiritual excelente. Se nivelará lo superior a lo inferior y el plano de la virtud ontológica resultará tapado. Olvidado.

De ahí la inmensa importancia que para Aristóteles reviste la cuestión crítica del eterno retorno como principio del método. Es decir: como inversión crítica del tiempo-cinético "natural», psicológico, cuando se trate del método de la verdad ontológico-práctica del ser que se dice en el lenguaje.

Nosotros ya hemos estudiado lo bastante esta cuestión hasta aquí, como para comprender que éste es el punto axial de la Filosofía Primera de Aristóteles, tal y como conviene recordar ahora para reconocerla en todas sus equivalentes formulaciones:

A) Que «lo primero en sí es lo último para nosotros».

B) Que lo último desde el punto de vista numérico o de la génesis, es lo primero, lo causal primero, desde el punto de vista del ser-acción-límite, en cuya investigación no puede procederse al infinito.

C) Que la acción tiene primacía sobre los procesos dinámicos potenciales a los que llamamos "movimiento" y "generación".

D) Que la verdad ontológica es práctica: es el comunicarse, transmitirse, recibirse, interpretarse y recrearse de la enérgeia kaì entelécheia, etc, etc.

Principios de crítica metodológica y orientación alternativa ontológica, donde se expresa siempre, tratándose de Aristóteles, el mismo punto de vista: el de la primacía del modo de ser plenamente activo propio del límite-fin inmanente y limitante (péras) de los lenguajes de la vida, sobre lo delimitado (peperasménon) causado, y sobre lo ilimitado (ápeiron) genérico-genético o material de las síntesis. Pues se ha de volver a pensar este problema esencial de acuerdo con sus diferencias y respetando al decirlo exactamente la misma terminología de Aristóteles, que ya había sido puesta antes en juego por la investigación del Filebo de Platón, recogiendo el problema socrático y presocrático del límite, del criterio o el bien primero. Un diálogo al que Gadamer (perfectamente consciente, como muy pocos, de la densa problemática que gira alrededor de la cuestión del sentido del ser del tiempo y del eterno retorno) dedica una atención pormenorizada, ya a partir de su investigación doctoral sobre la teoría del placer (hedonê), puesta en relación explícita por el planteamiento del Platón del Filebo con la cues- 
tión del límite, el noûs, el deseo y el bien supremo de la vida humana, pendiente de encontrar el criterio de lo mejor para poder regirse y orientarse ${ }^{157}$.

Ahora sí que empieza a poder entenderse cabalmente, en el contexto preciso de la hermenéutica de El inicio de la sabiduría de Gadamer, el sentido irónico de aquella alusión al bien-hacer de Anaxágoras, quien, al parecer, había sabido enlazar el alma corporal y el alma espiritual. Pues, por parte de Gadamer, no podía significar sino una explícita invitación a que Aristóteles entrara en la conversación ipara arrasar la elementalidad ilustrada del cientifico Anaxágoras! ${ }^{158} \mathrm{Y}$

157 Véase de H.-G.Gadamer: Platos dialektische Ethik. Félix Meiner Verlag, Leipzig, 1931. Gesammelte Werke 5, Griechische Philosophie I. Ed. Mohr Siebeck, Tübingen, 1985/1999, pp. 3163. También el escrito posterior de Gadamer: "Platos dialektische Ethik' - beim Wort genommen», ibíd., vol. 7, GriechistePhilosophie III, pp. 121-127. Ed.1991/99.

${ }^{158}$ Se ha de estudiar con detenimiento la impecable argumentación racional de esta objeción capital para Aristóteles: la misma objeción que contra Platón levantaba ya su discípulo a través de la crítica contra Anaxágoras, en el libro Alfa de los Metafisicos. A saber: que habiendo descubierto Anaxágoras el noeîn: el pensar del espíritu como primer principio, luego estropeara ese máximo hallazgo, haciendo funcionar al noûs como si fuera una causa motriz agente que hubiera de "moverse al mover" por hacerse relativa a lo causado: el magma de infinitas potencialidades indeterminadas de los spérmata que son la protomateria de Anaxágoras ordenada por el Noûs, espíritu o mente. Pero lo más interesante está en que, como decimos, el reproche de Aristóteles es el mismo en el caso del Noûs eficiente de Anaxágoras que en el del alma automotriz de Platón, y corre el riesgo de no ser entendido en ninguno de los dos casos, si no se tiene en cuenta la temporalidad del eterno retorno: la primacía de la acción extática, en que Aristóteles sienta la crítica del tiempo cinético natural y el error natural de todo psicologismo. Se trata en efecto, sin embargo, de una posición incontrovertible, por parte de Aristóteles en este punto axial. Pues, en la medida en que apela precisamente a la noción del límite, el bien ontológico o la unidad simple indivisible e incomposible del Criterio, no puede causar con causalidad eficiente, debido al orden del tiempo. Veámoslo: si el Noûs de Anaxágoras se pretende sin mezcla, simple o separado (choristón), y ésta ha de ser, en efecto, su única naturaleza como única condición desde la cual puede ser y hacer lo que hace, entonces no puede ser una inteligencia agente que hubiera de componerse, al pensarlas, con las posibilidades que ha de separar y discernir sin mezclarse ni siquiera con algo, ya que, como razona Aristóteles «si todo está en todo» en el modelo de Anaxágoras, mezclarse con algo sería mezclarse o confundirse con todo y ¿̇cómo podría entonces inteligir y discernir, de entre los repertorios múltiples de posibilidades conjugables que ofrece la protomateria, aquellas posibilidades composibles cuya combinatoria pudiera dar lugar a las unidades sintéticas compuestas, que a su vez se habrían de integrar en sistemas regulares de orden y finalmente en la unidad de sistemas del Kósmos?

Léase, sobre todo, desde esta perspectiva la crítica de Aristóteles que vierte un indispensable pasaje del libro A de los Metafisicos. 987b15-988b15. Un estudio pormenorizado de tal temática y la bibliografia del criticismo aristotélico contemporáneo más destacada sobre la misma se ofrece en: Para leer la Metafisica de Aristóteles..., pp.358-377; 474-483; 501 y ss. También las «notas"desde la 45 a la 345 del libro III, ibíd., pp. 516-557. En ellas se registran y comentan los lugares del 
esto porque, como sabe muy bien cualquier lector de Aristóteles, en la crítica de éste al noûs accidental o potencial de Anaxágoras (quien, habiendo descubierto el espíritu o el pensar del bien como arché, lo usa aún como fuerza agente motriz, situada - como si fuera una causa genética- en el antes de la temporalidad tecnológica) se compendia, de una vez y en un solo trazo, toda la crítica de Aristóteles al platonismo académico pitagorizado y (sin necesidad de recabar en los ágrapha dógmata) toda la crítica dirigida, en especial, a los últimos diálogos del maestro, y más concretamente, al Filebo y al Timeo, situados sin duda en la última -y por tanto en la presumiblemente más elaborada y definitiva- época de producción del fundador de la Academia. Pero ¿y esto por qué? Éste es, no se olvide, el problema que nos concierne, y ésta es la respuesta: porque, en efecto, el Filebo contesta a la pregunta decisiva por la condición de posibilidad de las síntesis y el criterio-bien de la mezcla con la repetición de la pregunta desplazada al plano de la respuesta. Lo que equivale a decir: con la síntesis paradigmática de "la buena mezcla" que está "antes" como criterio de la síntesis bien mezclada. Mientras que el Timeo desenvuelve tal «repetición», incapaz de alcanzar el plano de las diferencias-límites primeras, en el mito tecnológico-genético que ya casi de manera natural añade a esa buena mezcla sintética que ha de ser criterioorigen de la buena mezcla resultado, el soporte o sub-puesto fundamento de una mente como Sujeto de tales objetos.

Los modelos paradigmáticos para las copias que resultarán después y el dios tecnólogo que mitologiza al noûs de Anaxágoras, convirtiéndolo en un dios antropomórfico, o un ingeniero matemático-pitagórico, son consecuencia de esa lógica. Ya todo deviene así potencial-accidental, en medio de este dinamismo imaginario; y la crítica contundente de Aristóteles no puede hacerse esperar. Es contundente y tiene difícil réplica: la explicación tecnológica de Platón valdría para el mundo-orden artificial, pero no para la physis como espontaneidad autolegislada soberana, ni para la pólis libre y ética (virtuosa) como espontaneidad

Corpus relacionados críticamente con esta problemática. Por último, y nuevamente en relación a la doctrina del Bien ontológico en el Alfa de los Metaf: pp. 568-573. Gadamer está en lo cierto cuando señala con lucidez que la doctrina del Bien Ontológico - que es la del uno-límite- es la única esencial para poder medir la continuidad y la diferencia entre el platonismo de Platón y el platonismo crítico de su discípulo Aristóteles. Cfr. H.-G. Gadamer: «Amicus Plato magis amica veritas" (1968), Gesammelte Werke 6, Griechische philosophie II. Mohr Siebeck,Tübingen, 1985, pp. 71-89; „Freundschaft und Selbsterkenntnis. Zur Rolle der Freundschaft in der griechischen Erhik», Gesammelte Werke 7, Griechische Philosophie III. Mohr Siebeck, Tübingen, 1991/1999, pp. 396-407. 
autolegislada y soberana. No valdría, pues, tal esquema artificial, para ser aplicado a los ámbitos de la physis kaì pólis, que vendrían a ser tratados por Platón como objetos-accidentes o meros resultados. Como productos vaciados de toda dimensión ontológica, y puestos en manos de un Sujeto calculador o medidor, todopoderoso, mitológicamente concebido a imagen y semejanza del hombre tecnólogo y tecnocrático. Esa es la crítica inapelable de Aristóteles en defensa de los derechos de la diferencia: de la libertad-espontaneidad o soberanía autolegislada, tanto del ser-lenguaje de la naturaleza libre como de la ciudad y la ciudadanía libre y virtuosa.

Sin embargo - protesta firmemente Gadamer- esto no puede ser así, aquí pasa algo raro, algo muy complejo. $Y$ ni siquiera basta con clamar a voces que “iEspeusipo no es Platón!, por ejemplo, pues Aristóteles lo tiene tan perfectamente en cuenta que es por ello y no por otra cosa por lo que piensa estar defendiendo el verdadero platonismo de los eide-diferenciales y del bien ontologico contra lo que le parece ser la desviación hacia otras causas (las materiales-formales, numéricas) propias del pitagorismo e indiferentes al bien, como inversión que pone en peligro la esencia espiritual de la filosofía platónica. No, la traída cuestión crítica no puede, al menos, ser tan sencilla en el caso de Platón. Y ha de admitirse, entonces, como mínimo, el estatuto problemático de la cuestión misma. Pues no se puede olvidar, en efecto, tal y como nos pide Gadamer, que ya para Sócrates y Platón la teoría fisico-mecánica de Anaxágoras resultaba tan decepcionante como para que Sócrates hubiera de girarse a la ontología ética del alma, a fin de buscar allí lo arché noético como bien ontológico. Y por lo tanto -insiste Gadamer todas las veces posibles- en esta cuestión crucial, la orientación ha de referirse al ámbito del alma-vida en ambos casos: en el de Platón y en el de Aristóteles a la par. Y para ello importa no poco, entonces, pararse a comprender que por lo que se refiere al alma y al modo de ser propio del «régimen del alma", digamos, tanto Platón como Aristóteles son, por igual, hijos y discípulos del sabio Heráclito. Lo cual resulta indispensable para empezar a librar a Platón del malentendido que le atribuiría a él mismo un rebajamiento fisicista del noein espiritual y de su temporalidad propia.

Equivaliendo además, en efecto, a poder librar a Platón de haber confundido la causalidad final que mueve por amor y amistad (hos erómenon) del bien ontológico participativo, con la causalidad motriz eficiente relativa al mundo sensible y narrada por el mito del Timeo, de acuerdo con el esquema productivo no ya de la méthexis o participación sino de la mímesis del arte (téchne). De nada le sirve a Aristóteles entonces denunciar, con razón, contra Anaxágoras, que el 
bien ontológico y el noeîn espiritual no pueden actuar como si fueran causas genéticas o fuerzas productivas, dinámicas y agentes, según el chrónos del antes y el después, porque su acción, tratándose de los límites simples o intensivos, ha de consistir en actuar-ser al modo de la causalidad final modal cuyo modo de ser - plenamente y reflexivamente intensivo- ama y desea todo ser inconscientemente mientras vive y actúa; y ama, conscientemente de hacerlo, el hombre virtuoso y libre.

De nada le sirve a Aristóteles — protesta Gadamer- porque todo esto: el régimen intensivo del alma espiritual, que es el de la enérgeia kai entelécheia, propio de los noémata y el noeîn de Aristóteles, no es sino ¡el descubrimiento originario y genuino de la experiencia Heraclítea y platónica del fuego y el éros del bien ontológico! Y hay más, incluso mucho más aún, tal y como enseñará rotundamente la exquisita suavidad mayéutica de Gadamer, en estas lecciones: las lecciones heraclíteas del maestro alemán, que estamos siguiendo de acuerdo con en el texto de El inicio de la sabiduria.

Más aún: porque, al parecer, habría sido entonces Aristóteles quien se habría olvidado de la tragicidad del problema que todavía hacía temblar a HeráclitoPlatón, sumiéndolos a veces, a ambos, el Efesio y el Ateniense, en la más honda melancolía. A saber: que las cosas no son tan sencillas, ni basta ordenar el deseo del alma-corporal al deseo del alma-espiritual, haciendo que el primero se subordine al segundo y principal (otra vez para invertir el tiempo cinético-genésico) de acuerdo con la jerarquía ontológica de lo verdadero establecida a la indoeuropea, podríamos decir, tal y como dictaminan, en último término, Parménides y Aristóteles ( $y$ entonces ¿también Heidegger?). Por una razón terrible que es, no obstante, la condición de posibilidad de toda dialéctica y de todo pensar: que el alma-corporal como principio de vida en el hombre, no desea, no puede desear la muerte, por cuya asumpción como límite se abre el ámbito del alma-espiritual. Y porque los deseos dobles del alma están cruzados en las dos direcciones divergentes que tensan el interior luminoso del secreto trágico más críptico: que el deseo de vida mata, mientras que el deseo de muerte afirma, resucita. Así que, por relacionarse cruzados los dos deseos contradictorios y disyuntos del alma del hombre, ésta es tensada y desgarrada por lo otro constituyente de cada deseo, doblemente cruzado (o cruzado otra vez) tal y como se muestra en cuanto se considera la tensión sin centro de la síntesis disyuntiva abierta por la dialéctica trágica del alma.

Pues, en efecto, se trata de los dos máximos extremos: la vida y la muerte, que tiran del alma hasta casi partirla en dos descoyuntándola: la muerte como 
condición de la vida (alma) del pensar, que hace resucitar lo otro. La vida como condición de posibilidad de la potencia que mata a lo otro para el autoaseguramiento y la autoafirmación de lo mismo. Por la puerta de la muerte se entra en la vida de lo eterno, aquí y ahora: en el ámbito del pensar noético del hombre que sin génesis y sin movimiento o mediación extensa, salta de un lugar a otro con la inmediatez propia de aquello siempre disponible para lo otro que no se compone salvo mientras la acción de lo otro dura. El ámbito del uno-sabio heraclíteo y el noeîn-einai parmenídeo. Ese otro ámbito que descubren los dos ontólogos y es la comunidad de lo uno intensivo compartida por ambos. Lo mismo para ambos, igual que es lo mismo para Platón y Aristóteles la comunidad compartida del eîdos-bien. Mientras que, a la vez, por la puerta de la vida se entra en la conflagración de las potencias, la concurrencia, la guerra, la competitividad y la fuga reparadora en los ensueńos. Se entra en la autoidentidad defensiva que mata a lo otro para autoafirmarse y autopromocionarse en la sobrevivencia; se entra en el terreno de la repetición, la costumbre y el dogma excluyente de la alteridad, tendente a la universalización impositiva de los rasgos propios. Se entra en el terreno de la legislación y la sanción de las costumbres, el juicio condenatorio de la diferencia tenida por patógena y el ámbito de las mitologías realizadas en general. El ámbito del poder, sus mitos eficaces, y la voluntad de poder auto-referencial.

El arte está entre las dos puertas. Mira a los dos lados, como el poeta del Poema de Parménides, situado en el entre de los dos lugares-temporales. Como el funambulista de Nietzsche; como el texto del Über die Linie de Heidegger y como el entre (el zwischen) de Hölderlin. En el límite trazado en medio del abismo, inestable y siempre precario, siempre teniendo que retrazarse: el límite trágico, disyuntivo de por sí, hasta la abertura infinita y la distancia intensiva del acontecer, que tensan al máximo, hasta el límite, los extremos trágicos de la vida y la muerte, partiendo en dos el deseo del alma. El poeta de Parménides se sostiene en el límite del medio sin mirar al abismo, y sin dejarse aterrorizar por la disimetría divergente de los dos mundos a ambos lados del límite: el de las opiniones de los mortales, hijos de la noche, que ignoran que la ausencia es y desconocen, entonces, el sentido del tiempo, y el de la eternidad espiritual noética del pensar. El poeta mira-escucha lo diverso y piensa a la vez lo divergente dirigiéndose al vértice final del ámbito contradictorio desplegado: al pliegue intensivo del ser-vida (sólo-afirmación) como condición de posibilidad superior a la primera contradicción trágica: la vida-muerte, el ser-no-ser y su infinito desplegado. El argumento de Parménides es por eso irrefutable: el no ser es referencial, 
es relativo al ser, pero ¿el ser, entonces, es igualmente relativo al no-ser? ${ }_{\text {¡Pues }} \mathrm{No!}$, y ésta es la falacia de la lógica o la matemática, indiferentes al bien, que pierden de vista el deseo del alma trágica cultivada, y cultivada precisamente por la tragedia como paideía. Pues supongamos, en efecto, que ya hubiéramos dicho que sí a la comprensión del enlace indisoluble entre la vida y la muerte en el caso del hombre (los animales no saben que mueren, ni profesan culto a sus muertos. No parecen recordar a sus muertos). Así pues hemos dicho dos veces que sí: al decir que sí al vinculo entre el sí y el no; al afirmar la inextricable inseparabilidad del sí y el no, de la vida y la muerte, cuando, justo en ese momento, se abre el ámbito de la paz y el amor puro, sin contrario: el de la única afirmación necesaria en que se contiene la alétheia: la única verdad supradogmática descubierta por el sabio-poeta en el Poema de Parménides. A saber: que el ser-vida-simple es el principio ontológico primero y que el no-ser, la nada, no es, no la hay, no es primer principio ontológico, porque la muerte no es la nada: porque el no-ser es siempre relativo al ser, y porque no tenemos experiencia de la nada pero sí de la muerte de los otros.

Que toda muerte es relativa a la vida y que la vida, sin embargo "se dice dos veces»: en la referencia recíproca trágica y como polo referencial no recíproco de la misma: el que mantiene tensada y abierta la diferencia ontológica entre "lo ser» como afirmación sin contrario de la eternidad incondicionada que retorna por el deseo del bien-placer; $y$ «lo ser-no-ser» del dolor que pasa, olvida y se fuga. Éste es el descubrimiento de Parménides, sólo uno, únicamente éste: que la vida es superior a la vida-muerte; que el sí es superior al sí-no; y que el ámbito de las diferencias sin contrario, de los simples (unidades modales intensivas: monadológicas) que no se oponen entre sí, ni luchan, ni concurren, ni han de imponerse, ni se alternan para prevalecer, es superior al mundo del poder de la guerra y la pugna dinámica entre las fuerzas, que rige en el ámbito de la vida-muerte. Es Parménides, a quien continuará después Empédocles, cantando la superioridad del amor y la no-violencia de la unidad, quien descubre el ámbito del noeîn espiritual racional, que es el mismo ( $t \grave{o}$ autó) que el ser-pensar como afirmación de afirmación: el sí que se dice dos veces, como vértice último del horizonte convergente del poetizar-amar de la vida-muerte y el sentido trágico de la vida. Su única ley ontológica y la condición de su eterna continuidad. La afirmación absoluta que descubre la superioridad ontológica de la vida sobre la vida-muerte. $\mathrm{La}$ apertura que descubre cómo la vida-ser es siempre superior a la muerte y cómo la muerte ha de subordinarse en todos los casos a la vida, porque en todos los casos, todo no-ser es relativo al ser y el no-ser no es nunca primer principio onto- 
lógico. Ser-Pensar: este único principio ontológico, esta única verdad supradogmática, es suficiente y basta y sobra para orientar la vida del hombre; porque con este único beso de lo divino en la mente (noein) del lenguaje del hombre, se traza la diferencia ontológica entre el ser y el devenir, y la jerarquía del orden que subordina la violencia de la muerte y la lucha por la sobrevivencia a la afirmación absoluta del ser-bien de la vida. Por comprenderlo perfectamente Aristóteles volverá a la casa del padre tras una crítica en profundidad del innecesario parricidio platónico, tendencialmente nihilista a partir del diálogo El Sofista.

Pues para siempre el carro del poeta Parménides se mantiene firme en el límite sobre el abismo, gracias a estar atento a ese único principio que hace retornar el orden alternante del día y la noche separándolos a la vez por el único límite indivisible que resguarda su diferencia: su síntesis disyuntiva.

\section{II.5. La Anámnesis creativa: Gadamer y Heráclito por detrás de Platón. La Teología de Gadamer: la virtud productiva de la esperanza hermenéutica.}

¿Y Heráclito? ¿Es esto lo mismo que ocurre en el caso de Heráclito? En cierto modo sí, salvo que ahora no se trata del darse del ser, cuya afirmación se entrega como sentido del darse-ocultarse de la vida-muerte, sino que se trata del correlativo alcanzar del fuego de las flechas de los aforismos de Heráclito, viniendo desde el rayo hasta los confines insondables del mar infinito del alma, para dispararse otra vez hacia arriba: hacia el límite de la luz brillando en la noche. La máxima disyunción-tensión de la verdad abierta, que se pliega súbitamente, sin mediación, de golpe, en el acontecer de la verdad, y tan pronto se da la vuelta hacia un lado, como se la da hacia el otro, a ambos lados del límite: «tò hèn gár phesi diapherómenon autò hautôi symphéresthai hósper harmonian tóxou te kaì lyras" (Simplicio 187 a, Heracl. fr. 51 y fr. 8) ${ }^{159}$.

Por eso, siendo cierto que Parménides y Heráclito dicen lo mismo, también lo es que explorar la diferencia de esa mismidad es el empeño de Heráclito. Pues es Heráclito quien nos descubre quizá lo más asombroso, a saber: que los dos

${ }^{159}$ Citado por Gadamer, quien lo traduce y comenta así: ««Lo uno que diverge en sí mismo, converge siempre consigo mismo». Una formulación dialéctica sumamente paradójica (...). A Heráclito se le atribuye que lo uno y lo plural no son algo sucesivo, sino que son a la vez toda la verdad del ser». El inicio de la Sabiduría, ed. española, p. 37. Orig. alemán: "Heraklit -Studien» (1990), Gesmmelte Werke 7, Griechische Philosophie III. Mohr Siebeck, Tübingen, 1991, p. 47. 
deseos del alma y sus dos extremos correspondientes, la vida eterna y la muerte, no sólo son contradictorios y divergentes, asimétricos y disyuntos, sino que también están cruzados (como habíamos empezado a ver). Y es por ello —obtendrá Gadamer-por lo que no puede, ni fácil ni difícilmente, conducirse el carro del poeta trágico por la senda escarpada del bien-ser-límite sin el concurso de todas las fuerzas de las que dispone el mortal. ¡También con las fuerzas de los muertos divinos! Contando, pues, Heráclito con la ayuda de la potencia espiritual de los muertos inmortales, que nos hablan para seguir siendo y para entregarnos el concurso indispensable de su-nuestra palabra, en respuesta al único don ontológico que nosotros podemos ofrendarles a cambio para ser. El único que tenemos: la vida efímera de nuestra-su palabra y memoria viva, mientras vivamos. Mientras se trasmite la voz viva común de nuestro aliento mortal por el suyo animado en el ahora, cada vez ${ }^{160}$. Que hablen «nuestros otros" por nosotros y con nosotros, que no se interrumpa la conversación por su ausencia, ya que volvemos a encontrarles en el sueño-vigilia del pensar que rememora y enciende una luz en la noche. La misma luz del rayo en la vigilia de la noche del alma, cuyo infinito se concentra hasta tocar el límite transversal de la muerte (del otro) en vida y la vida del otro en nuestra muerte. Así lo enseña Heráclito:

Muerte (y no vida) es cuanto vemos despiertos, cuanto vemos dormidos visiones reales (fr.21). No se debe hablar ni actuar como los que duermen (fr. 73) ${ }^{161}$. Para los despiertos el kósmos es uno y común, mientras que cada uno de los durmientes se vuelve hacia el suyo propio (fr. 89).

Y Gadamer interpreta:

La «sabiduría una» de Heráclito no es cómo pasa lo Uno a lo Otro, sino que también sin tránsito sea ya lo otro. Sin transición, súbitamente, como

160 Enseña Gadamer: «Pero su logos es uno. Él lo percibe en fenómenos tan diversos como el fluir de las cosas. El cambio brusco de fuego a agua, del dormir al despertar, y descubre el mismo enigma en todo, en la llama que se consume y apaga, en el movimiento que se inicia por sí mismo y cesa por sí mismo. En todas partes ve el milagro de la vida, el enigma de la vigilia y el misterio de la muerte (...) — y cita Gadamer a Heráclito, comentándolo así-: «De esta razón que existe siempre, resultan desconocedores los hombres" (...) Este texto estaba seguramente destinado a ser recitado. Entonces el que hablaba podía articular de tal modo que la palabra «siempre» irradiaba hacia los dos lados, tiñendo las palabras vecinas". Ibíd., ed. española, pp. 49-50; ed. alemana, p. 56.

161 Citado por Gadamer, ibíd., ed. española, p. 54; ed. alemana, p.60. 
el rayo (...) la expresión espacial de tal alteridad sin transición es el entrar en contacto, prender ( háptesthai) — palabra clave del profundo fragmento 26: “Un hombre en la noche prende para sí una luz, apagada su vista, y, vivo como está, entra en contacto con el muerto al dormir. Despierto, entra en contacto con el durmiente (fr. 24)». La sentencia plantea muchos enigmas ${ }^{162}$.

Entre ellos éste: el del origen oculto del lenguaje - enseñará el heraclíteo Gadamer--, que se remonta al culto a los muertos capaz de mantenerlos vivos, por resucitarlos en la rememoración transversal donde vuelve a darles la palabra, transformada una y otra vez, viva y sostenida. Cada vez más rica y compleja, incrementada en intensidad por la creatividad insólita de la memoria virtual del lógos. Donde se libera la diferencia de la interpretación (y la discusión de las interpretaciones distintas) de lo que sí puede volver y vuelve transfigurado ${ }^{163}$.

No es tan sencillo para el hombre mantenerse en la senda parmenídea ascendente y unitaria que pretenden trazar las hijas del sol. Pues tampoco basta con afirmar y comprender que, en efecto, la ausencia es - como ya sabe esencialmente el pensar de Parménides-. El fondo infinito del problema aporético del alma no está sólo ahí, ni reside sólo en esto; no reside en saber conducirse bien por ningún camino, sino en sumergirse en el cruce dialéctico extremo. Ya que la

162 Gadamer: ibíd., ed. española, p. 76; ed. alemana, p. 76. Véase nuestro El nacimiento de la filosofia en Grecia, op. cit., pp. 201-203 y nota 2 de pp. 165-67. Cristina García Santos vierte el aforismo 26 en un hermoso castellano: «El hombre en la noche enciende una luz para sí, cuando se han apagado sus ojos. Vivo, toca al muerto al dormir; despierto, toca al durmiente" (ibíd., p. 203).

${ }_{163}$ Para la doctrina gadameriana-heraclítea del origen del lenguaje en el culto racional-sagrado a los muertos, y el Lógos-dialéctico-hermenéutico entre los muertos y los vivos, los inmortalesdivinos y los mortales, véanse dos textos indispensables escritos por Gadamer con una magistral claridad comunicativa que sabe no traicionar la complejidad de la temática trágica por excelencia: la de la relación cruzada entre la muerte y la vida indisolubles, sin mediación, y en las dos direcciones de los dos lados del límite délfico, donde se cruzan la ausencia y la presencia. La voz y el sueño, la oralidad y la escritura se comunican, así, por la puerta oculta del lenguaje que abre (y guarda su secreto de futuro) en la tinaja de barro de Pandora. Los dos escritos referidos se incluyen en la colección de textos de Gadamer, reunidos bajo el título: El Estado oculto de la salud, y son éstos: "Experiencia de la muerte» y "Vida y alma». Trad. española de Nélida Machain. Ed. Gedisa. Barcelona, 2001. Orig. alemán: Über die Verborgenheit der Gesundheit. Shurkamp Verlag Frankfurt am Main, 1993. El texto "Experiencia de la muerte» se basa en una conferencia pronunciada por primera vez el 10 octubre 1983 en la Süddeutsche Rundfunk de Heidelberg. Gesammelte Werke 4, pp. 288-294. El texto "Vida y alma" responde a una conferencia dictada por Gadamer durante el semestre de verano del 1986, en la Universidad de Zúrich. 
primacia de la vida sin contrario se da-ofrece sólo en el ámbito del noeîn abierto por la asumpción de la muerte propia en vida, de modo que la obscuridad más profunda es la condición de posibilidad de la llegada de la luz hasta que ambas se tocan, y en ese límite en que se cruzan la vida y la muerte es donde se da el vértice del sentido del lógos. Un cruce simultáneo que Heráclito y Gadamer explicitan como el estar en vigilia del sueño o el encenderse en la noche la luz del alma para que entren por ese puente los muertos que regresan a la vida gracias a compartir su-nuestra palabra y entregarnos su-nuestra memoria común ${ }^{164}$.

${ }^{164}$ Véase el riguroso estudio de Zoran Jankovic sobre la diferencia entre Heidegger, Gadamer y Derrida, a partir de la muy distinta asignación que otorgan a la muerte y la diferencia misma, cada uno de ellos, en sus respectivas filosofias de la finitud-infinitud y del lenguaje: "La critique herméneutique et la critique déconstructiviste de la conception heideggérienne de la mort", cap. IV del volumen Au-delà du signe: Gadamer et Derrida. (Le dépassement herméneutique et déconstructiviste du Dasein?). Ed. L'Harmattan, París, Budapest, Torino, 2003, pp. 191-231. Jankovic señala con acierto que para Gadamer no es la experiencia de la muerte radicalmente singular, de Zeit und Sein, sino la experiencia del lenguaje, lo que ofrece un "absoluto de la vida" como sobrepasamiento de la vida-muerte, a la vez que una dimensión político comunitaria y no meramente individual del problema de la diferencia. Pero al no tener en cuenta al «Segundo Heidegger» y textos como Zeit und Sein, por ejemplo, donde se expresa un Heidegger-Parménides presocrático, no puede percibir Jankovic cabalmente la profunda unidad de Gadamer y el Segundo Heidegger, enlazados por una ontología del lenguaje postmetafísica, donde el límite y la alteridad trazan la diferencia transcendental del ámbito de lo posibilitante-determinante. Ello fuera ya de cualquier residuo idealista o metafísico relativo al sujeto identitario y el fundamento: los categoremas lógicos hipostasiados por el re-presentar óntico. Pues se trata de pensar el ser sin el ente [Cfr. Heidegger: Zeit und Sein (1961), en Zur Sache des Denkens, Max Niemeyer Verlag, Tübiengen, 1988]. Lo cual equivale, dicho en otras palabras, a que, para Gadamer, no es ya la muerte individual, de la que no tenemos experiencia, sino la respuesta comunitaria a la muerte de los otros, como esencial-proveniencia del diálogos del lenguaje, la que abre la posibilidad del pensar a los hombres. Los animados que mueren. Los animados cuya vida pertenece al tiempo, pertenece al lenguaje y pertenece a la polis. Heidegger y Gadamer están en lo mismo: el giro a la alteridad constituyente que diferencia la filosofía hermenéutica, tanto de la dialécrica de la superación meramente polémica, plegada a una inmanencia crasa positivista, donde la diferencia se diluye o se absorbe, como de la transcendencia adialógica del Otro absoluto e inconmensurable, que es típica de la Desconstrucción con que J. Derrida prosigue a E. Levinás. Lo posibilitante para la ontología hermenéutica es el otro y lo otro, radicalmente inmanentes. Lo posibilitante es la diferencia cruzada entre los inmortales-divinos (muertos) y los mortales (vivos) porque esa es la esencia temporal del lenguaje comunicativo, comunitario. De ahí que el último Heidegger y su discípulo Gadamer se encuentren sin resto en el diálogo transversal ontológico que señala la diferencia del lógos trágico de Heráclito, y, por lo tanto, se encuentren en Nietzsche, como ha señalado con acierto cabal la hermenéutica de Gianni Vattimo. Si bien no en cualquier Nietzsche, sino en el Nietzsche presocrático que señala hacia el Heráclito-Zaratustra de una resurrección inmanente: trágica y comunitaria. Una resurrección postcristiana que se abre tras la despedida de toda fe en la salvación y todo dogma mitológico-esca- 
"Lo mismo es vivo y muerto, despierto y dormido, joven y viejo; pues esto de un vuelco es aquello, y aquello a su vez, de un vuelco, es eston (fr.88) ${ }^{165}$.

Así pues, no basta con ordenar al alma individual que asuma la muerte, y que lo haga no sólo en el momento de la muerte propia, cuando el cuerpo se muere, sino ya en vida, para posibilitar que se abra aquí y ahora el reino del espíritu: el ámbito de la vigilia de lo mismo-diferencial. No basta ni es posible, porque el alma no lo quiere, no puede quererlo y prefiere al contrario no saber: soñar, dormir, mentir, fugarse... prefiere no saber. Prefiere los mitos, los relatos, las imágenes infinitas, y, a lo sumo, las buenas mezclas del límite con las síntesis de la imaginación y la memoria a las que llamamos "imágenes bellas»... no puede, no quiere. El alma prefiere soñar. No puede renunciar a las imágenes de la belleza... Pero, mientras tanto, tampoco el alma que ha descubierto el espíritu puede ya vivir sin la experiencia noética de lo abierto: de la eternidad inmanente y la inocencia de ese otro lugar-tiempo donde se da lo extático, lo que no muere, no se corrompe, no se genera. El ámbito donde se da el milagro de lo que se multiplica sin dividirse y aparece y des-aparece con la intensidad inmediata de lo súbito. El ámbito donde la ausencia es y se descubre el sentido del ser-pensar. El ámbito espacio-temporal pleno de la gratuidad y la inocencia, la amistad sin resto y la verdad del misterio del ser-pensar. El ámbito donde se da la experiencia del devenir del ser y la comunidad del crear y el recibir se virtualizan reciprocamente ${ }^{166}$.

Por eso la sabiduría trágica de Gadamer, releyendo a Parménides con Heidegger y a Heráclito desde el eterno retorno que señalaba Nietzsche, vuelve a enseñarnos que Aristóteles y Platón han pensado lo mismo: han pensado el bien ontológico entre los dos, situándose cada uno en la distancia extrema que abre la

tológico. Una resurrección postmetafísica o postmoderna. Cfr. Gadamer: "Der Tod als Frage” (1975) y «Die Erfahrung des Todes» (1983), Gesmamelte Werke 4, Neuere Philosophie II, pp.161175 y 288-297, respectivamente.

${ }_{165}$ Nuestra trad. en El nacimiento de la filosofia..., op. cit., p. 199.

166 Léase tal experiencia, por ejemplo, en las inolvidables páginas del Gadamer más aristotélico comentando la frase de Göethe "Wort und Bild — «so wahr, so seiend»—" (1992), Gesammelte Werke 8: Ästhetik und Poetik I, pp. 373-400. Estupendo el comentario de Ángel Gabilondo en la "Introducción" que dedica a la colección de textos gadamerianos Estética y hermenéutica, donde éste se incluye, en op. cit, pp. 279-307. A. Gabilondo titula así este excelente estudio introductorio suyo: «Leer arten (ibíd., pp. 42), que puede contarse entre las mejores contribuciones de la hermenéutica iberoamericana al criticismo de Gadamer. Desde luego el lema de este ensayo filosófico podría aplicársele también a él mismo, pues de «leer arte» se trata, en el caso de una escritura castellana tan hermosa como la que aquí se pone en juego. 
tensión del lenguaje al ahondar en cada uno de sus dos límites extremos, disyuntos: los de nuestra experiencia originaria y el acontecer de su relación constituyente y expropiante. Una síntesis disyuntiva dialógica que tensa y abre la experiencia del pensar desde el rememorar originario del alba de Occidente hasta nuestro ahora, cuando la hermenéutica se torna a descubrir y recibir, otra vez, el acontecer transformado de la mismidad-diferencia entre la vida y la muerte, la obsuridad y la luz, los mortales y los inmortales, divinos y humanos, en una comunidad cruzada que es a la vez la dialéctica trágica del alma y su lógos. Una puerta secreta señalada por la estrella oculta de la esperanza hermenéutica. La que comunica con el acontecer de la distancia trágica, extremamente tensa, entre el darse del ser al pensar-lenguaje y el rehusarse desde el alma al pensar del $\operatorname{ser}^{167}$.

No es tan sencillo erradicar el dualismo, y desde tal punto de vista - que Gadamer vuelve a replantear con la coherente hondura que estamos viendolas imágenes del Fedro piatónico en que el auriga lucha por mantener el equilibrio del carro tirado disyuntamente por los dos deseos divergentes del caballo blanco y el caballo negro, adquieren el contexto interlocucional de una respuesta trágica al demasiado id́lico paseo por el borde del límite del poeta parmenídeo en pos de la verdad. Sí claro, iba guiado por las hijas del sol, pero, sin duda -claman Platón y Heráclito-, ¡están también las hijas de la noche!, cuyo coro trágico canta al unísono ahora en los aforismos del sabio Efesio de modo solemne: "El sol no sobrepasará sus medidas. $Y$ si no, Las Erinias, guardianas de la justicia, lo descubrirán" (fr. 94). Si el sol se excediera, las hijas de la noche lo pondrían en evidencia, porque "Es necesario sofocar la desmesura (hybris) más que un incendion (fr.43). O como Gadamer comenta con acierto: es la prudencia atenida al límite de la finitud la que debe impedir ambas desmesuras: la del éxtasis noético de tendencia posthumanista que excede la intensidad del fuego benévolo dador de luz y calor, transformándolo, por exceso, en fuego devorador, que se extiende arrasando cualquier diferencia, tanto como la cerrazón por defecto de la mera autoafirmación sin alteridad. La que es propia del alma empecinada en el aseguramiento de la voluntad de potencia, cerrada al deseo de exponerse a

167 La "Tierra" y el «Mundo» del Origen de la obra de Arte de Heidegger (1936), muestran así la urdimbre de su procedencia espiritual hermenéutica, remontándose, por detrás de la reescritura heideggeriana de las lúcidas distinciones modales aristotélicas, hasta la filosofía de la "armonía oculta" del misterio que rige el lógos de Heráclito. El lógos aforístico oracular que saca a la luz como tal misterio, el pensar délfico del enigma trágico, en toda su radicalidad afirmativa. En ese ahí del ser-uno de la vida-muerte, se planta el lenguaje de la hermenéutica de Gadamer. 
aprender $-\mathrm{y}$ dejarse alterar — por nada que provenga del ámbito espiritual de lo divino inmanente.

Este es el estado oculto de la hermenéutica de Gadamer y su legado heraclíteo más asombroso: que el día y la noche, la vigilia y el sueño, la vida y la muerte siempre indisolublemente unidas entre sí, han de poder tener espacio-tiempo para alternarse en el juego que se da súbitamente la vuelta a su otro, devolviéndole la palabra en el espaciar transversal de un diálogo del alma que impide abrirse paso al absoluto ilimitado de la nada. Mientras asume el mortal, con la responsabilidad madura de la prudencia sabia, la vigilia o el cuidado del darse del lenguaje eterno del ser divino... de la vida-muerte y la resurrección inmanente comunitaria. Así lo enseña Heráclito:

Inmortales mortales, mortales inmortales: viviendo éstos [los mortales] la muerte de aquellos, habiendo muerto aquellos [los mortales] la vida de éstos [los inmortales] (fr. 62). Morada para el hombre es la divinidad (fr. 119). La morada humana no alberga entendimiento, la divina sí (fr. 78). Una sola cosa en lugar de todas las demás eligen los mejores: la gloria perenne de los mortales. La mayoría en cambio está saciada como ganado (fr. 29). Para el que allí es, se levantan y se tornan guardianes en vela de los vivos y los muertos (fr. 63). El pueblo debe pelear por su ley como por sus murallas $(\text { fr. } 44)^{168}$.

Pues es cierto y, en efecto, muy peligroso, y muy difícil de aprender, de acuerdo con la experiencia de cada uno y la experiencia del relato de la historia de Occidente, que al alma espiritual no le importa nada la muerte de su propio sujeto individual, así que no puede comprender demasiado bien la violencia auto-afirmativa de la vida en pos de su aseguramiento y su ascenso, su promoción y su afirmarse negando a todo otro concurrente. Habita en el reino de la resurrección trasfigurada que es la actividad del pensar entregado a lo divino inmanente y las cuestiones del sentido. $Y$ desde su perspectiva propia suele detestar y desdeñar, en realidad, las exigencias del alma del cuerpo en cuanto se hacen algo perentorias y se tornan distintas a las del lecho de los jardines del placer. Normalmente, el alma espiritual se suele volver condescendiente, pero aborrece las mediaciones, las fragmentaciones y las dilaciones porque son exactamente lo que la mata o la impide ser. Mientras que, por su parte, la potencia antropomórfica hacia la repetición

${ }^{168}$ El nacimiento de la filosofia..., op. cit., pp. 207-209. 
identitaria de los caracteres de las costumbres y los rasgos genéticos del alma-cuerpo, que caracteriza a todas las sociedades dogmáticas del poder, impone a gritos los tristes desafueros de lo "humano demasiado humano" que cree poder escapar de la muerte matando toda alteridad. Los dos extremos se combinan, a menudo, merced a la diferencia de clases sociales, o merced a la guerra exterior y la paz interior, en el caso de los estados modernos, dotando de una triste estabilidad compensatoria a ambas corrupciones desmedidas. Pero en tal armonización de ambos errores sólo se tapa de modo violento la dialéctica trágica del alma sin que tenga lugar su educación eficaz a través de una paideía trágica que sí descanse en la verdadera justicia democrática jentre los vivos y los muertos! Tal y como desde Heráclito y Sócrates reclama la filosofía. Es por estos motivos por los que, si bien sólo una educación estética y trágica del alma del hombre puede dar lugar a la gran cultura que Nietzsche reclamaba, sólo una educación hermenéutica del hombre puede dar lugar a la resurrección espiritual de los muertos inmortales que sí puedan volver en tanto que pasados posibles a tomar una palabra inédita, creativa y verdaderamente histórica. La palabra no-dicha y no-pensada nunca antes por la memoria-lenguaje que la alberga como posibilidad insospechada ${ }^{169}$.

Ésta es la teología de la historia inmanente que está en el espíritu oculto de la hermenéutica como filosofía de la historia trágica e inmanente. Enteramente diversa de la teodicea moderna-secularizada característica de la modernidad, que opera continuando, por la vía del ateísmo y el agnosticismo, la escatología de la salvación del cristianismo metafísico, proyectado en la historia, la ciencia y el progreso tecnológico ${ }^{170}$. Hay también otras posibilidades de lectura del cristia-

169 Véase de Pascal Michon: Poétique d'une anti-anthropologie. L'hermenéutique de Gadamer. Ed. Vrin, París, 1999, especialmente caps VIII y XIX sobre la confrontación de Heidegger y Hegel en Gadamer, pp. 181-246.

${ }^{170}$ Dice Gadamer: «La dureza y el rigor de la ilustración moderna se deben a su origen: una ciencia que se ha desarrollado a partir de la modificación de la Antigüedad pagana emprendida por el cristianismo. Al colocar al Dios en un "más allá", se ha obligado al conocimiento humano a autoasegurarse, con lo cual se ha terminado por transformar la finalidad del conocimiento en sí mismo. Un nuevo afán de medición, un nuevo ideal de construcción racional, ha fundado un nuevo imperio, Este imperio está regido por el ideal del saber dominante que -en forma de investigación - va desplazando permanentemente los límites de lo dominable. Pero si es verdad que esta Ilustración científica - al igual que la del mundo antiguo- encuentra sus límites en la incapacidad de concebir la muerte, también es cierto que el horizonte dentro del cual se puede mover el pensamiento acerca del enigma de la muerte está trazado por las doctrinas de la salvación; es decir, entre nosotros, por las doctrinas cristianas en todas sus variaciones, según las iglesias y las sectas. Para el pensamiento discurrente debe resultar tan incomprensible como esclarecedor el hecho de 
nismo si se le hace remontarse a sus orígenes espirituales heraclíteos, tal como estamos viendo, pues la Pietas de Heráclito está cruzada por el amor a la diferencia ontológica máxima entre la palabra y el silencio de los muertos y los vivos. Occidente no ha conocido nada así hasta el momento. ¡Gadamer el tradicionalista! - dicen los modernos progresistas nombrando a su estable dual complementario-. ¡Gadamer el reaccionario, el burgués! — dicen los violentos modernos metafísicos siempre en pos de su perpetua adolescencia, despreciadora y superadora de cualquier pasado-. Mientras que Gadamer sonriendo - y tendiéndole la mano también a Hegel — le daba la vuelta a la violenta Metafísica de la Historia que se alimentaba de la fagotización de todos sus pasados, para liberarlos de la muerte, como olvido del olvido ${ }^{171}$. Para permitirles la resurrección espiritual de volver a tomar la palabra dentro de los límites precisos del lenguaje racional diferencial e histórico. El que sí se abre con la nueva filosofía del espíritu que llamamos «Hermenéutica». Es como si sólo la hermenéutica de Gadamer hubiera aprendido el hondo y sutil sentido de la doble lectura que hace Heidegger de Nietzsche y de la crítica de Heidegger al Nietzsche destructor de la metafísica como historia de Occidente. La objeción era ésta: que pretendía destruir demasiado y por ello, paradójicamente, destruía demasiado poco, convirtiéndose de modo doble y ambiguo, por una parte, en expresión de su forma

que la verdadera superación de la muerte no pueda consistir en otra cosa que en la resurrección de los muertos, que para los creyentes, constituye la máxima certeza y, para los demás, algo inconcebible, pero no más inconcebible que la muerte misma». La experiencia de la muerte, op. cit., ed. española, p. 85. Conviene volver a recordar a Heráclito: «A los hombres les aguarda una vez muertos lo que no esperan ni imaginan» (fr. 27).

171 Véase en El retorno griego de lo divino, op. cit., el epígrafe 3 del cap. IV: «Nietzsche, Heidegger y los griegos: la reproposición de una cultura trágica a partir de las ontologías del límite y la estructura dialógica del olvidon, pp. 67-73. Véase también el epígrafe 4 del mismo Cap. IV: "Diferencia ontologica y eterno retorno: la piedad del pensar» (ibíd., pp. 73-79). Sobre la Modernidad como realización del nihilismo metafísico y la Verwindung (dislocación, alteración) que la hermenéutica postnihilista o postmoderna opera en ella para saltar de ella a otra era menos violenta, a partir de Nietzsche Heidegger, Gadamer, Vattimo y Deleuze, entre otros, que de distintos modos retornan al inicio originario no-dicho y no-pensado en los mismos textos de nuestra tradición documental, considero muy útil tener en cuenta los textos y comentarios que están reunidos en las "Notas y Escolios" al mencionado cap. IV de este libro (ibíd., pp. 256-303). En ellas se refiere y estudia la bibliografía filosófica relevante, que no se puede omitir cuando se aborda el criticismo contemporáneo relativo a la cuestión del nihilismo. La posición alternativa de la Postmodernidad filosófica respecto del nihilismo se aborda detalladamente en el libro IV en su conjunto: "La diferencia dislocada. Nihilismo y metafísica de la hermenéutica cristiano-ilustrada. Las genealogías ontológicas des-heredadas: Nietzsche, Heidegger y los griegos" (ibíd., pp. 49-117). 
moderna más acabada: la voluntad de poder como libertad absoluta y, por la otra, la de Zaratustra y el eterno retorno, en el puente de tránsito hacia el otro inicio que reclamaba Hölderlin y desemboca en la hermenéutica postmoderna de Gadamer $^{172}$. Las huellas de Heidegger, Nietzsche y Hegel convergen así en Gadamer,

172 Cfr. Juan Luis Vermal: "Quién es el Nietzsche de Heidegger?", en la revista de la Sociedad española de estudios sobre Niezzsche «Estudios-Nietzsche», vol. 1, año 2001, pp. 176-182. La interpretación de J.L. Vermal, el traductor al castellano de los dos vols. del Nietzsche de Heidegger (Nietzsche, ed. Destino, Barcelona, 2000), prosigue y corrobora esencialmente, en este breve artículo, las tesis que nosotros defendemos en el estudio "La relación Heidegger-Nietzsche con la crítica del nihilismon, en El retorno griego de lo divino en la postmodernidad, op. cit., pp. 55-67. A saber: A) La doble y ambigua lectura que Heidegger necesita históricamente hacer de Nietzsche, como culminación de la metafísica moderna de la voluntad de voluntad, por un lado y por el otro como apertura hacia el otro inicio de Occidente. B) El carácter de tránsito hacia el otro inicio que Nietzsche desbordado por la dimensión radicalmente creativa de su Zaratustra, alcanza y abre gracias al puente que traza Zaratustra: el maestro del eterno retorno de la historia occidental. C) Que los textos nietzscheanos de Heidegger seleccionados son los pertinentes para comprender la interpretación que Heidegger hace de Nietzsche. No obstante, por no considerar J.L.Vermal, de modo explícito, en el breve espacio de ese artículo, ninguna de las lecciones y los textos presocráticos del "Segundo Heidegger" que, a partir de los años 40 y hasta la muerte del filósofo, se concentran en las ontologías de Parménides y Heráclito, no llega sino a insinuar - desprovisto de la necesaria determinación que este punto crucial exige hoy para nosotros y para la actual tarea del pensarque el otro inicio es la puerta presocrática a la ontología de otro espacio-tiempo-lenguaje de la historicidad: el de la hermenéutica postmoderna. Véase, por ejemplo, J. Vermal, ibíd., p. 177. En los mismos Vorträge und Aufsätze sin ir más lejos, podía Vermal haber visto dónde desemboca el señalar alternativo de Heidegger, pues éste sitúa el escrito "Quién es el Zaratustra de Nietzsche», no en cualquier lugar hermenéutico sino precisamente en el espacio IV de este volumen que termina con un tríptico de ontología presocrática: el texto IX dedicado al Lógos del fr. 5 de Heráclito; el X, dedicado a un pasaje del Poema de Parménides, bajo el rótulo "Moira y el XI dedicado nuevamente a Heráclito con el título "Alétheia», que interpreta el aforismo 16 (op. cit., pp. 153-274).

La cuestión sólo tiene importancia desde el punto de vista del criticismo riguroso que debe presidir la investigación académica de la relación Heidegger-Nietzsche. Pues, de tener en cuenta el hilo de la referencia presocrática, la conexión entre Nietzsche y Heidegger se perfila de un modo radical hacia la ontología del límite y el misterio, que pone en juego "Heráclito el obscuro", ya que pensada en profundidad la henología y la modalidad de lo posible y necesario en lo mismo y lo otro de Parménides y Heráclito, no es sino el Dios de Delfos, el Dios Dionisos-Apolo, quien contesta oracularmente a la pregunta de Heidegger. "¿Quién es el Zaratustra de Nietzsche?», con estas otras señales: «Uno, lo sabio, único, quiere y no quiere ser llamado con el nombre de Zeus» (fr. 116). "Común a todos es el pensar. Es necesario que los que hablan con inteligencia se apoyen en lo común a todo, como la ciudad en su ley, incluso mucho más firmemente, pues todas las leyes humanas se alimentan de una sola, la divina; ella domina tanto cuanto quiere, y basta para todo y sobra» (fr. 113-114). "A lo que jamás tiene ocaso ¿cómo podría uno ocultársele?» (fr. 16). «El señor del cual es el oráculo de Delfos ni dice ni oculta sino que señala” (fr. 205). Después de Heidegger es el Gadamer de los textos presocráticos quien mejor ayuda a comprenderlo. 
hacia atrás, hasta desembocar en la filosofía de la resurrección trágica e inmanente de Heráclito, leído el Efesio desde la comprensión ontológica y metodológica del eterno retorno de la diferencia, que ya hemos estudiado. Y, desde allí, desde la honda espiritualidad heraclítea, llegando hasta este Gadamer inédito: el que ha sabido cambiar no sólo la historia, sino la filosofía de la historia y la racionalidad occidental; el Gadamer que nos descubre sólo el análisis profundo de su hermenéutica presocrática, y en particular de su hermenéutica heraclítea.

Un Gadamer nietzscheano y trágico. El Gadamer de la inocencia ontológica heraclítea: «El tiempo (Aión) es un niño que juega, que mueve sus peones: de un niño es el mandon (fr. 52). El que disuelve todo espíritu de venganza contra la vida, y da lugar a la gran reconciliación. La que sólo puede abrirse por el gran perdón que Heidegger no podía darse ni siquiera a sí mismo. Un Gadamer nietzscheano que se ha vuelto capaz, al poder comprender incluso los motivos profundos del alma de Platón, y al subrayar la comunidad diferencial de Aristóteles y Platón en el bien ontológico, de saltar por fin a un espacio-tiempo intralingüístico menos violento y enteramente diverso del de la historia del nihilismo occidental. El espacio-tiempo hermenéutico postnihilista que Nietzsche exigía hacer posible a favor de la reproposición de una cultura trágica donde el arte y la filosofía puedan habitar legítimamente; participando en la educación estética del alma del hombre. La misma que Gadamer, siguiendo el señalar de Elorigen de la obra de arte de Heidegger hacia la Poética de Aristóteles, vuelve a reproponer como paradigma de la paideía clásica, inscrita en el corazón de toda su obra ya a partir de Verdad y Método: la estética como lugar de la verdad ontológica. La ontología estética y hermenéutica donde se desenvuelve, en la obra de Gadamer, la ontología estética del juego. Pues, en efecto, tratándose de la reflexividad del alma libre no cabe educación moral más que de las costumbres, digamos urbanas o convencionales, y eso no está mal, desde luego, con tal de recordar de inmediato que éstas no pueden aspirar por sí mismas a la verdadera esfera del êthos: la morada libre en que cada uno de nosotros ha de conseguir habitar. Mientras que, por contraste, sólo una educación estético-trágica en que podamos experimentar, a través del arte, la puesta en escena de la muerte, puede catartizar el terror y el asco, la venganza y la piedad (el éleos y el phóbos) hacia lo otro y los otros, dando lugar al lazo social de la comunidad civil solidaria ${ }^{173}$.

173 Téngase en cuenta para todo lo que sigue el texto de Gadamer «Das Beispiel des Tragischen" (pp. 133-139), en la sección II de Wabrheit und Methode. "Die Ontologische des Kunstwerks und ihre hermeneutische Bedeutung» (pp. 107-174). GW1, Mohr-Siebeck, Tübingen, 1960/1990. 
Pues conmovida el alma del espectador por la puesta en escena artística del abrumador desenlace trágico, el escalofrío y la desolación del éxtasis con que le afecta la tragedia en tanto mimesis estética del destino atroz del mortal y la ineludibilidad del misterio de la muerte, se produce (enseña Gadamer) una unificación del alma respecto de lo que la separaba de lo otro y los otros, rechazado por repugnancia ante la crueldad del mundo. Se produce una asumpción de la ley que iguala entre sí a los héroes, los ricos, los famosos y los plebeyos, así como una serenidad, templada al fuego, que atempera la cobardía de la fuga y la temeridad de la inconsciencia, abriendo el lugar cívico-político de la paz social y la esperanza racional. Una asumpción comunitaria y pública de la propia finitud, que libra al alma de su pretensión de libertad y responsabilidad infinita, enseñándole que no todo está en nuestras manos y volviéndola, además de comprensiva e indulgente hacia sí misma, comprensiva hacia los otros y sus errores, con cierta independencia de su condición o sus aparentes privilegios. Una educación estético-trágica del alma que libremente experimenta la posibilidad de atemperar la cobardía y la temeridad, dando lugar a la firme esperanza de una comunidad política libremente racional. Una sociedad razonable y comprensiva. La esperanza del Lógos hermenéutico.

Ésta es la estrella de la esperanza, la puerta oculta de la esperanza que Gadamer y Platón depositaban en el dios Hermes desde que en el Protágoras - consagrado a la investigación del ser del lenguaje comunicacional- rescribiera el filósofo socrático la pesimista creencia transmitida por el mito de Hesíodo y rehabilitada por Esquilo, haciendo que Zeus mismo tuviera que enviarnos a HermesEpimeteo para evitar que los mortales se exterminen entre sí, una vez en poder del fuego divino que el titán Prometeo entregó a los hombres robándolo a los dioses ${ }^{174}$. La estrella del señalar de Hermes, templada al fuego de una esperanza

${ }^{174}$ Véase la referencia literal de Gadamer a Hesíodo, Esquilo y Platón, a propósito de la esperanza racional, del lenguaje, en un texto ya referido: «Experiencia de la muerte», en El estado oculto de la salud, op. cit., p. 8 y ss. Orig. alemán: «Die Erfahrung des Todes", GW 4, pp. 290-94. Conviene advertir cómo la filosofía de la esperanza trágica de Gadamer, retrocede desde el Protágoras de Platón a la interpretación que pone en juego el Prometeo de Esquilo. Pues si, en efecto, el poeta trágico griego ya produce el giro lingüístico a la esperanza afirmativa, depositada en el don de ignorar el momento de la propia muerte, podría pensarse que no es sino en el Protágoras de Platón dónde ésta radical finitud se transfiere y explicita como esperanza depositada en la comunidad civil de los hombres, hecha posible por la intervención del Hermes divino, que Zeus les envía para compensar el poder del fuego titánico. Pues, puesto el fuego en manos de los mortales huyendo de la muerte, se ha de tornar en fuego que mata, en fuego devastador, en nom- 
hermenéutica que sí es posible, por primera vez, y se hace cada vez posible, por haber abierto Pandora la tinaja-tumba del mal y habernos atrevido, desde entonces, a encarar las calamidades que asolan al hombre: experimentar la muerte y el dolor injustificado de los otros y de nosotros mismos, atravesando y sosteniendo el dolor hasta que haya resucitado a través de nosotros todo lo que tienen de vida incumplida, posible, inocente, afirmable e inagotable los pasados muertos y los presentes muertos. Hasta que haya resucitado todo su sí posible a través del trabajo y el placer del lenguaje, del amor, y del arte, dando lugar a la esperanza cabal y posible de una comunidad hermenéutica donde la comprensión de las leyes, la justicia, el arte y la filosofía estén legitimados. ¿Y no era esto lo que decía Heidegger, saludando al post-nihilista Zaratustra de Nietzsche, tras afirmar que «la salvación tiene que venir del lugar — del lenguaje — donde la esencia de los mortales cambian? ?75 $^{175}$

bre de la sobrevivencia y el autoaseguramiento de los unos contra los otros. Es necesario, pues, para de-limitar la desmesura, la hybris ilimitada del fuego que incendia, recibir también el fuego del temple de la prudencia y la sabiduría, pero éstas no se alcanzan por el mismo camino del lenguaje.

Y es aquí donde Gadamer se da la vuelta a lo otro: a la esencia oculta del lenguaje. Pues el fuego benévolo ni se roba por la fuerza titánica ni se reclama por la emancipación, ni se consigue por un aumento de conocimientos, técnicas o informaciones. Es el fuego que sabe que ignora y que no puede, y que no domina. El que enciende una luz en la noche del alma para mirar-escuchar el misterio de la noche misma. El fuego benévolo dirigido a lo otro que preside el recibir y el comprender de lo otro, también en la amistad y la solidaridad. El fuego de la esperanza trágica en el límite, en el cruce inmanente del logos transversal entre los mortales-inmortales, que brota de la inocencia y la serenidad precisamente cuando se comprende que no es necesaria ninguna metafisica de la salvación, ni ninguna religión sobrenatural de la redención escatológica, para esperar y confiar en la resurrección inmanente de los muertos. Basta, al contrario, con no desplazar permanentemente los límites y sí volverse —en el caso de Occidente— al pensar de la piedad originaria de la filosofía, comunitaria y espiritual, trágica; cuya noética heraclítea sólo recogió el cristianismo, si bien mezclándola con escatologías transcendentes orientales, y mitologías del poder occidentales. ¡Todo esto enseña Gadamer en sus "Heraklit-Studien" y en su "Der Erfahrung des Todes»!

${ }^{175}$ Tiene que venir del lenguaje. Del arte distintivo del mortal -y de su orientación ya hacia la vida, ya hacia el desplazamiento indefinido de la muerte. Esto es lo que puede cambiar. Esto es lo que ha abierto Niezzsche siguiendo a Hölderlin, y lo que Heidegger explora también de la mano de Rilke, en el texto que estamos comentando: "i Y para qué poetas"?, que justamente postcede a "La frase de Nietzsche "Dios ha muerto"» en la edición de los Holzwege (Caminos del Bosque) y pertenece, estructuralmente, al mismo arco filosófico de Heidegger que la colección de textos Conferencias y Articulos, en la que se incluye el ya referido "¿Quién es el Zaratustra de Nietzsche?». Escrito este, en el que Nietzsche-Zaratustra, no interpretado ahora desde el interior de la metafísica, se convierte en el maestro del Eterno Retorno de lo mismo, que permite saltar de la historia del nihilismo y su espíritu de venganza y resentimiento contra la vida, al otro inicio. El que señala Heidegger a partir de los Beiträge zur Philosophie (Vom Ereignis). Para una relación y estudio detalla- 


\section{Dice Martin Heidegger:}

«La más profunda venganza consiste para Nietzsche en aquella reflexión que pone los ideales ultratemporales como los absolutos; unos ideales medidos contra los cuales lo temporal tiene necesariamente que rebajarse a sí mismo como lo propiamente no-ente. Pero ¿̨cómo podrá el hombre acceder al dominio sobre la tierra, cómo puede tomar en su custodia a la tierra como tierra si rebaja y mientras rebaje lo terrenal, en la medida en que el espíritu de venganza determina su reflexión? Si hay que salvar a la tierra como tierra, entonces primero tiene que desaparecer el espíritu de venganza.

De ahí que para Zaratustra la liberación de la venganza sea el puente a la suprema esperanza. Pero ¿en qué consiste esta salvación de la voluntad contra el pasar? ¿Consiste en una liberación de la voluntad en general? ¿En el sentido de Schopenhauer y del budismo? En la medida en que según la doctrina de la Metafísica moderna, el ser del ente es voluntad, la liberación de la voluntad se equipararía a una salvación del ser, y, con ello, a una caída en el vacío de la nada. Sin duda para Nietzsche la liberación de la venganza es la liberación de lo adverso a la voluntad, de lo opuesto a ella y de lo que la rebaja, pero en modo alguno un desprenderse de todo querer. La liberación libera a la voluntad de su No y la hace libre para un Sí. ¿Qué afirma este Sí? Justamente aquello que la contravoluntad del espíritu de venganza niega: el tiempo, el pasar.

Este Sí al tiempo, es la voluntad de que el pasar permanezca y no sea rebajado a la nada. Pero ¿cómo puede permanecer el pasar? Sólo así: que como pasar no esté sólo yéndose continuamente sino viniendo siempre. Sólo así: que el pasar y lo que pasa de este pasar regrese en su venir como lo Mismo. Pero este mismo regreso sólo es un retorno que permanece si es un regreso eterno (...) ¿Quién es el Zaratustra de Nietzsche? Es el maestro que a la reflexión que hasta ahora ha estado vigente quisiera liberarla del espíritu de la venganza, llevándola al Sí, al eterno retorno de lo Mismo. Zaratustra como maestro del eterno retorno, enseña el ultrahombre.

El estribillo de esta enseñanza dice según una nota póstuma: "Refrán: sólo el amor debe juzgar, el amor que se olvida de sí mismo en sus obras». Como maestro del eterno retorno y del ultrahombre, Zaratustra no está ense-

do de los textos nietzscheanos de Heidegger, véase El Retorno de lo divino..., op. cit., p. 61. También para el Nietzsche de Heidegger, ibíd., pp. 55-117. 
ñando dos cosas distintas. Lo que enseña forma un todo coherente porque una cosa pide la correspondencia de la otra ${ }^{176}$."

Pide un hombre que ya no desee ser una versión secularizada del dios todopoderoso creador, vetotestamentario, que había legitimado la venganza infinita. Y pide, por lo mismo, que el hombre de buen temperamento, el de las pasiones alegres, sin resentimiento contra la vida-muerte, se atenga al criterio del espíri-

${ }^{176}$ M. Heidegger: "Quién es el Zaratustra de Nietzsche?", en Artículos y Conferencias, trad. de E. Barjau., op. cit., pp. 86-87. Cfr. mi El retorno de lo divino..., op. cit., p. 63 y ss. Veamos ahora que nos enseña Heidegger de la Esperanza hermenéutica: En este mismo texto imprescindible, el filósofo subraya, igual que Gadamer, la relación indisoluble transversal, que se da, para la hermenéutica trágica, entre la vida y la muerte, cuando asomándose al alma de Zaratustra comenta Heidegger lo siguiente: "La nostalgia es el dolor de la proximidad de lo lejano (...) el maestro, como ya vimos, está en camino de regreso hacia su esencia más propia. Es el convaleciente. En la tercera parte del Así hablaba Zaratustra, inmediatamente después del fragmento titulado "El convaleciente", sigue aquel fragmento que lleva por título "De la gran nostalgia». Con este fragmento, el antepenúltimo de la 3. parte, alcanza la obra Así hablaba Zaratustra su punto culminante. En una Nota póstuma (XIV, 285) señala Nietzsche: "Un sufrimiento divino es el contenido del tercer Zaratustra». En el fragmento "De la gran nostalgia», Zaratustra habla con su alma. Según la doctrina de Platón, regulativa para la metafísica occidental, la esencia del pensar descansa en el diálogo del alma consigo misma (...). En diálogo con su alma Zaratustra piensa "el más abisal de sus pensamientos» (...). Zaratustra cuando enseña a su alma aquél decir es el maestro del eterno retorno de lo Mismo. Este retorno es la plenitud inagotable de la vida gozoso-dolorosa. Hacia allí se dirige «la gran nostalgia» del maestro del eterno retorno de lo Mismo. De ahí que en el mismo fragmento a la "gran nostalgia" se le llame la "nostalgia de la sobre-abundancia". La "gran nostalgia" vive sobre todo de aquello de lo que ella saca el único consuelo, es decir, la confianza.

En lugar de la palabra antigua Trost (consuelo) (emparentada con ella: trauen, estraguen, tener confianza, fiarse) en nuestra lengua ha entrado la palabra Hoffnung (esperanza). "La gran nostalgia" entona y determina a Zaratustra, animado por ella, a su "más grande esperanza». Pero ¿qué es lo que le autoriza y le lleva a ésta? (...). La contestación a la pregunta que acabamos sde formular se da en la 2. ${ }^{\text {p }}$ parte de la obra, en la parte preparatoria. Aquí Nietzsche, en el fragmento "de las Tarántulas» hace decir a Zaratustra: «Porque que el hombre sea librado de la venganza: esto para mí es el puente a la más alta esperanza, y un arco iris después de largas inclemencias del tiempo". Martín Heidegger: "Quién es el Zaratustra de Nietzsche”, op. cit., pp. 80-81.

Este texto de Heidegger ofrece una corroboración de particular calado para le hermenéutica trágica del alma (vida) y el espíritu (noûs) abierto por la asumpción de la muerte-límite. Nostalgia y esperanza, muerte y vida, los dos deseos-límites divergentes del alma, se cruzan tanto en Zaratustra como en Gadamer porque ambos son ya, igual que Heidegger-Nietzsche, iniciados en el Lógos de Heráclito, hijos de Heráclito, cuya sabiduría se dirige a todos. Y Heidegger prosigue: «Porque que el hombre sea liberado de la venganza: esto para mí es el puente a la más alta esperanza, y un arco iris después de las inclemencias del tiempom. Qué singular y qué extraño para la opinión habitual que la gente se ha hecho de la filosofía de Nietzsche ¿No pasa por ser Nietzsche el insti- 
tu del amor a lo otro y la afirmación de lo otro, como único criterio rector de los juicios y como límite de su interpretación ${ }^{177}$. El criterio-límite que, olvidándose de sí mismo, permite el regresar eterno de lo sido. Zaratustra-Heráclito es el maestro de la racionalidad hermenéutica de Heidegger y Gadamer porque la hermenéutica es el pensamiento que pertenece y pone en juego el alma espiritual del eterno retorno como filosofia de la historia postmetafísica no-violenta o no-nihilista. Una filosofía de la historia hermenéutica-postmoderna que opera como praxis racional comunicativa del diálogo filosófico, transversal y eterno, entre el serlenguaje y sus inagotables historicidades inéditas posibles.

Ésta es la teología filosófica de Gadamer, latiendo en el corazón de la hermenéutica. En el centro vivo de la hermenéutica. La estrella de la esperanza de Hermes-Platón. La que Nietzsche, Heidegger, Gadamer y Heráclito, Parménides, Aristóteles, y tantos otros... antes y después de nosotros... han depositado en el lógos del hombre, señalando su bien más preciado y el único oriente de esa perla espiritual infinita en que se abisma lo divino del origen de la experiencia del lenguaje. La esperanza que se vierte en la palabra eterna de Heráclito, desde hace ya algo más de dos mil quinientos años, para que siga viva la memoria documental y virtual de Occidente: "eàn mè élpetai, anélpiston ouk exeuréseì (Heráclito, fr.18). Gadamer traduce y comenta así:

"Si uno no espera no encontrará tampoco lo inesperado». Es gracias a la esperanza que lo que aparece, precisamente porque era imprevisible y parecía inalcanzable, pudo presentarse de un modo totalmente diferente a lo que se esperaba. Entonces puede haber una sorpresa, podría haber un cumplimiento. Sólo al que tiene esperanza se le puede enviar lo inesperado ${ }^{178}$.

Tal es el preciso señalar de la estrella de la esperanza, que radicalizado en la palabra de Gadamer-Heráclito, abre la puerta oculta del lenguaje a la resurrección inagotable de los pasados posibles propia de la filosofía de la historia hermenéutica. Una firme esperanza depositada en la ontología del límite y la fini-

gador de la voluntad de poder, de la política de la violencia y de la guerra, de la "furia de la bestia rubia"?". Ibíd., p. 81.

${ }^{177}$ Es Gianni Vattimo, en nuestros días, el más coherente discípulo de Nietzsche, Heidegger y Gadamer, quien ha desenvuelto la hermenéutica postmoderna explícitamente en ésta que es su esencial dirección: la del amor racional como criterio-límite de la interpretación. Véase "La contribución de Gianni Vattimo a la hermenéutica del siglo XX", op. cit., pp. 99-134.

${ }^{178}$ H.-G. Gadamer: El inicio de la sabiduria, op. cit., p. 67. 
tud, que posibilita también el renombrar más cercano del alma espiritual como memoria o eternidad transfigurada para toda vida-muerte. $Y$ ello radicalmente. en base precisa a la afirmación y asumpción de la única verdad trágica radical que se anuda en el ineludible y verdaderamente indisoluble nexo oculto entre la vida y la muerte. El nexo disyuntivo visto en las dos direcciones del espacio-tiempo dialogal: el que retorna. Porque toda vida-muerte tiene memoria y olvido, de modo que toda vida-muerte recuerda el camino de vuelta y aparece-desaparece, se presencia y ausencia, a su modo. Yéndose al otro lado del límite y volviéndose hacia este otro lado, a la vez.

\section{Bibliografia}

\section{SINOPSIS DE LAS GESAMMELTE WERKE}

H.-G. GADAMER, Gesammelte Werke, J. C. B. Mohr (Paul Siebeck), Tübingen.

- Band 1: Hermeneutik I: Wabrheit und Methode I: Grundzüge einer philosophischen Hermeneutik. - 1986.

— Band 2: Hermeneutik II : Wabrheit und Methode II : Ergänzungen, Register. 1986.

— Band 3: Neuere Philosophie I: Hegel-Husserl-Heidegger.

— Band 4: Neuere Philosophie II : Probleme, Gestalten. - 1987.

- Band 5: Griechische Philosophie I. - 1985.

- Band 6: Griechische Philosophie II. - 1985.

- Band 7: Griechische Philosophie III : Plato im Dialog. - 1991

— Band 8: Ästhetik und Poetik I : Kunst als Aussage. - 1993.

— Band 9: Ästhetik und Poetik II : Hermeneutik im Vollzug.

— Band 10: Hermeneutik im Rückblick. - 1995.

\section{ARTÍCULOS Y OBRAS DE H.-G. GADAMER SOBRE PRESOCRÁTICOS}

Referencias de los títulos alemanes por su lugar en las Gesammelte Werke (excepto cuando no están incluidos aquí) y correspondencias con las traducciones españolas existentes.

1. Mito y Razón (Traducción de J. F. Zúñiga, Paidós, Barcelona, 1997) contiene, en este orden:

— "Mythos und Vernuft», GW 8, pp. 163-9.

— «Mythos und Logos», GW 8, pp. 170-3. 
- "Mythologie und Offenbarungsreligion», GW 8, pp. 174-9.

- «Der Mythos im Zeitalter der Wissenschaft», GW 8, pp. 180-8.

— «Reflexionen über das Verhältnis von Religion und Wissenschaft», GW 8, pp. 160-2.

— "Zur Phänomenologie von Ritual und Sprache», GW 8, 400-40.

2. El inicio de la sabiduría (Traducción de A. Gómez Ramos, Paidós, Barcelona, 2001) contiene, en este orden:

— "Vom Anfang bei Heraklit" (1974), GW 6, pp. 232-41. (Traducido por "Sobre la transmisión de Heráclito")

— «Heraklit-Studien» (1935), GW 7, pp. 43-82.

— "Antike Atomtheorie» (1935), GW 5, pp. 263-79.

— «Plato und die Vorsokratiker» (1964), GW 6, pp. 58-70. (Traducido por «Platón y la cosmología presocrática»)

- "Die Griechische Philosophie und das moderne Denken» (1978), GW 6, p. 3-8.

- "Der Natur Begriff bei den Griechen und in der modernen Physik", en Colloquium philosophicum. Annali del Dipartimento di Filosofia 1 (1994-95), p. 9-22.

3. El inicio de la filosofia occidental (Lecciones compiladas por Vittorio de Cesare, traducción de J. J. Musarra, Paidós, Barcelona, 1995) está publicado originalmente en italiano (L'inizio della Filosofia Occidentale, a cura di Vittorio de Cesare).

Traducción alemana: Der Anfang der Philosophie, Reclam, Stuttgart, 1996.

4. Otros artículos no traducidos al español:

- «Das Lehrgedicht des Parmenides» (1936), GW 6, pp. 30- 57.

— "Vorgestalten der Reflexion» (1966), GW 6, pp. 116- 28.

— «Über das Göttliche im frühen Denken der Griechen» (1970), GW 6, pp. 15470.

- «Das Vaterbild im griechischen Denken", GW 6, 218-32.

- "Zur Aktualität von Hellas": Richard Harder, Die Eigenart der Griechen (1963); Wolfwang Schadewaldt, Hellas und Hesperien (1975). (Es una recensión de esos dos libros).

- «Parmenides oder das Diesseits des Seins»,, GW 7, pp. 3-31.

- «Hegel und Heraklit», GW 7, pp. 32-42.

- «Natur und Welt. Die hermeneutische Dimension in Naturerkenntnis und Naturwissenschaft», GW 7, pp. 418-442. 
5. Un artículo de tono histórico-cultural donde Gadamer destaca algunas aportaciones de la filosofía griega que hoy necesitamos recordar y reactivar los europeos para de-limitar la modernidad. Viene a validar la tesis de cómo la hermenéutica postmoderna gadameriana es la de-limitación griega de la modernidad:

— "Die Gegenwartsbedutung der griechischen Philosophie", en Hermeneutische Entwürfe, Tubinga, Mohr, 2000, pp. 97-111.

Este texto parte de una conferencia que Gadamer pronuncia en la Universidad de Atenas en 1972, y, posteriormente publicada en Praktika tis akadimias Athinon, 47, 1972, pp. 243-261. Hay dos traducciones españolas: una a cargo de C. de Francisco Pereña Blasi y A. Alegre Gorri: «La significación actual de la filosofía griega», Resurgimiento (Barcelona), 1979, pp. 17-27; y otra a cargo de A. Agud y R. de Agapito: «El significado actual de la filosofía griega", Acotaciones hermenéuticas, Trotta, Madrid, 2002, pp. 125142.

6. El estudio en original italiano sobre "I Presocratici» en Vittorio Mathieu (ed.): Questioni di Storiografia filosofica. La Scuola, Brescia, 1975, pp. 13-86.

7. El escrito "Wort und Bild «So Wahr, so seiend»" (1992). "Palabra e imagen "Tan verdadero, tan siendom", en GW 8, pp. 373-440. Trad. española de A. Gómez Ramos en Estética y hermenéutica, Técnos, Madrid, 1996. Por contener éste una de las versiones más comunicativas de la ontología modal (estética) de la acción (enérgeia). Filosofía originaria de Aristóteles, que Gadamer hace suya y supone una verdadera clave de acceso a la comprensión tanto de las actuales ontologías noéticas hermenéuticas como de las presocráticas. 